Jornal de

\title{
Políticas Educacionais
}

Número 16 | 2014

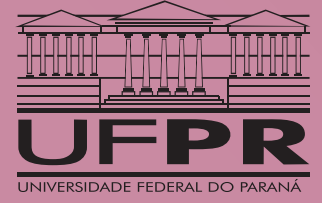

Núcleo de
Eolíticas
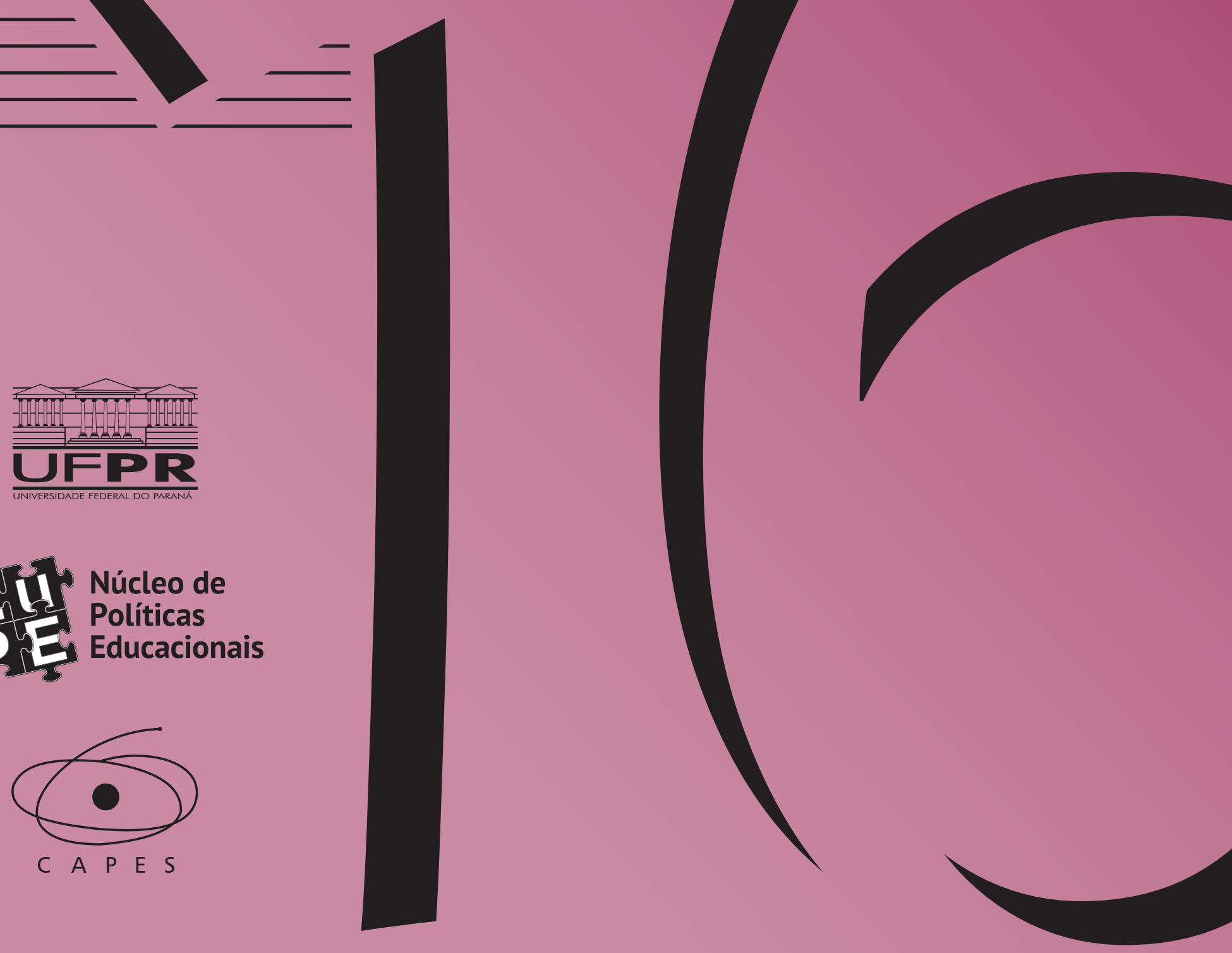


\section{Jornal de Políticas Educacionais}

JPE | Curitiba | v.8, n.16 | Julho-Dezembro de 2014

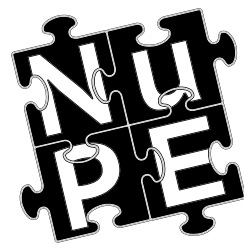

Núcleo de

Políticas

Educacionais

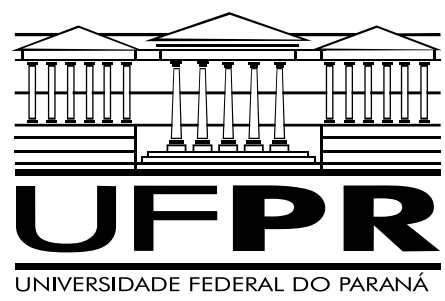




\section{JORNAL DE POLÍTICAS EDUCACIONAIS}

Universidade Federal do Paraná - Setor de Educação

Núcleo de Políticas, Gestão e Financiamento da Educação - NuPE/UFPR

Rua Gal. Carneiro, 460 - $4^{\circ}$ andar - Sala 407/C

80.060-150 - Curitiba - PR - Brasil

Tel.: 41-3360-5380

jpe@ufpr.br

http://www.jpe.ufpr.br

http://www.ser.ufpr.br/jpe

\section{Comitê Editorial:}

Ângelo Ricardo de Souza (UFPR)

Ana Lorena Bruel (UFPR)

Marcos Edgar Bassi (UFPR)

\section{Conselho Editorial:}

Andréa Barbosa Gouveia (UFPR), Ângela Hidalgo (UNICENTRO), Cesar Gernomino Tello (Universidad Nacional Tres Febrero, Argentina), Gladys Beatriz Barreyro (USP), Juca Gil (UFRGS), Jefferson Mainardes (UEPG), João Ferreira de Oliveira (UFG), Luiz Souza Júnior (UFPB), Regina Maria Michelotto (UFPR), Robert Verhine (UFBA), Rosana Cruz (UFPI), Rubens Barbosa Camargo (USP), Sebastián Donoso Díaz (Universidad de Talca, Chile), Taís Moura Tavares (UFPR), Theresa Adrião (UNICAMP), Vera Peroni (UFRGS).

JORNAL DE POLÍTICAS EDUCACIONAIS é uma publicação semestral do Núcleo de Políticas Educacionais da Universidade Federal do Paraná - NuPE/UFPR, em consórcio com a Linha de Pesquisa em Políticas

Educacionais do Programa de Pós-Graduação em Educação - PPGE/UFPR, que aceita colaboração, reservando-se o direito de publicar ou não o material espontaneamente enviado à redação. As colaborações devem ser enviadas ao JPE, conforme orientações contidas no final desta edição ou nas páginas do periódico na internet: http://www.jpe.ufpr.br ou www.ser.ufpr.br/jpe.

Jornal de Políticas Educacionais / Núcleo de Políticas Educacionais da Universidade Federal do Paraná NuPE/UFPR - v.1, n. 1 (1 semestre de 2007) - Curitiba: NuPE/UFPR.

volume 8, número 16 - Julho/Dezembro de 2014

Semestral

ISSN 1981-1969

1. Educação - Periódicos. 2. Política Educacional - Periódicos. I. NuPE/UFPR

Indexação:

BBE - Biblioteca Brasileira de Educação (MEC/INEP)

Clase (Base de Datos Bibliográfica de Revistas de Ciencias Sociales y Humanidades)

Diadorim - Diretório de Política de Acesso Aberto das Revistas Científicas Brasileiras (IBICT) Index Copernicus

Portal de Periódicos (CAPES)

SER - Sistema Eletrônico de Revistas da Universidade Federal do Paraná (SER/UFPR)

Sumários de Revistas Brasileiras (FUNPEC-RP)

DRJI - Directory of Research Journals Indexing

(Periódico integralmente disponível via eletrônica) 


\section{SUMÁRIO}

\section{APRESENTAÇÃO}

Os Editores

\section{ARTIGOS}

Plano Nacional de Educação, Conferência Nacional de Educação e a construção do Sistema Nacional de Educação: dilemas e proposições

Luiz Fernandes Dourado.

Diversidade, educação e relações étnico-raciais na Conae-PR

Paulo Vinícius Baptista da Silva, Rosa Amália Espejo Trigo, Lucimar Rosa Dias

Políticas Curriculares para o Ensino Médio e para a Educação Profissional: propostas, controvérsias e disputas em face das proposições do Documento Referência da Conae 2014

Márcio Luiz Bernardim, Monica Ribeiro da Silva.

Gestão democrática, participação popular e controle social: análise das emendas paranaenses ao documento referência da Conae 2014

Adriana Dragone Silveira, Taís Moura Tavares

Em tempos de valorização dos profissionais da educação

Maria Dilnéia Espíndola Fernandes

O desafio do regime de colaboração no novo Plano Nacional de Educação

Luiz Araujo.

Recursos públicos para a educação: percentual irrevogável do PIB

João A.C. de Monlevade.

O Custo Aluno-Qualidade Inicial como proposta de justiça federativa no PNE: Um primeiro passo rumo à educação pública de qualidade no Brasil

Daniel Cara

O debate acerca do financiamento da educação na etapa municipal da Conae 2013/2014 de Curitiba-PR Jokasta Pires Vieira Ferraz, Ângelo Ricardo de Souza.

RESENHA 101

RESUMOS DE TESES E DISSERTAÇÕES. 105

INSTRUÇÕES PARA SUBMISSÃO DE TRABALHOS 


\section{CONTENTS}

\section{PRESENTATION}

Os Editores.

\section{ARTICLES}

National Education Plan, National Education Conference and the construction of the National Education System: dilemmas and propositions

Luiz Fernandes Dourado.

Diversity, education and ethnic-racial relations in Conae-PR

Paulo Vinícius Baptista da Silva, Rosa Amália Espejo Trigo, Lucimar Rosa Dias

Curricular Policies to High School and Professional Education: proposals, controversies and discussions in the face of Conae 2014 Reference Document

Márcio Luiz Bernardim, Monica Ribeiro da Silva.

Democratic Administration, popular participation and social control: analysis of the Paraná state's amendments to the Reference Document of Conae 2014

Adriana Dragone Silveira, Taís Moura Tavares

Education professional's times of appreciation

Maria Dilnéia Espíndola Fernandes

The challenge of collaborative arrangment in the new National Education Plan

Luiz Araujo.

Resources for public education: irrevocable percentage of GDP

João A.C. de Monlevade.

The Quality Student Initial Cost as a federal justice proposed in the PNE: a first step towards the quality of public education in Brazil

Daniel Cara

The debate about Financing of Education in 2013/2014 Curitiba Conae's Conference

Jokasta Pires Vieira Ferraz, Ângelo Ricardo de Souza

REVIEWS 101

SUMMARIES 105

INSTRUCTIONS FOR SUBMITTING PAPERS 


\section{Apresentação}

"A Conferência Nacional de Educação (Conae) é um espaço democrático aberto pelo Poder Público e articulado com a sociedade para que todos possam participar do desenvolvimento da Educação Nacional" (BRASIL, 2014). Com esta apresentação, o governo federal, depois de um atraso de nove meses, realizou a segunda edição desta importante conferência, que se mostrou, já em 2010 na I Conae, como um espaço de debate e decisões importantes sobre a educação brasileira.

O Jornal de Políticas Educacionais buscou reverberar esta discussão e, neste número 16, traz aos leitores uma coletânea de nove artigos que tematizam a Conferência Nacional de Educação, bem como o Plano Nacional de Educação, uma vez que esta importante peça da política educacional estava no centro da própria temática da conferência ${ }^{1}$.

Esses noves artigos se somam aos outros sete publicados no número 15 e, assim, atingimos um total de 16 artigos publicados no volume 8 (2014), ampliando o espaço de divulgação dos achados de pesquisa e das reflexões sobre a temática das políticas educacionais.

Neste número, o primeiro artigo é de autoria do Conselheiro Luiz Fernandes Dourado, professor titular da Universidade Federal de Goiás e integrante da Câmara de Educação Superior do Conselho Nacional de Educação. Neste artigo, professor Dourado debate a importância da Conae e da ação articulada da sociedade visando a elaboração de políticas educacionais, com enfoque na centralidade da necessidade da construção de um sistema de regulamentação da educação.

O artigo seguinte é de autoria dos professores Paulo Vinícius Baptista da Silva, Rosa Amália Espejo Trigo e Lucimar Rosa Dias, da UFPR. O trabalho toma a temática da educação e diversidade, e avalia como a Conae, na etapa paranaense, trata esta relação. Os autores trabalham com o conceito de diversidade e suas distintas expressões nos documentos da conferência, e focalizam a leitura sobre as relações étnico-raciais, em especial as proposições dirigidas para o estabelecimento de igualdade étnico-racial e educacional. O trabalho, desenvolvido pelos autores, evidenciou um debate muito intenso de posições diversas, mas mostra que ao final o que prevaleceu foi a reafirmação e aumento das políticas educacionais voltadas às minorias, em uma tendência que busca combinar políticas focais com avanços das políticas universalistas.

O terceiro artigo é assinado pelos professores Márcio L. Bernardin, da Unicentro, e Monica Ribeiro da Silva, da UFPR. O trabalho analisa as proposições de políticas para o Ensino Médio e para a Educação Profissional à luz do documento referência da Conae 2014. Mas, o artigo também lida com outras referências acerca desta temática, como a Lei de Diretrizes e Bases da Educação e as Diretrizes Curriculares exaradas pelo Conselho Nacional de Educação. O texto evidencia um embate de concepções e uma disputa por projetos societários e educativos que marcam a formulação dessas políticas educacionais.

O artigo das professoras Adriana Dragone Silveira e Taís Moura Tavares, ambas também da UFPR, trata das propostas de emendas paranaenses ao Documento Referência da Conae 2014, para o eixo "Gestão democrática, participação popular e controle social”. O caderno de emendas preparado para a discussão na Conferência Estadual de Educação do Paraná, para o eixo em destaque constou com 356 sugestões. Da análise se destacam as emendas referentes: à participação popular por meio de Conselhos; sobre os mecanismos de participação na promoção da democratização da gestão dos sistemas de ensino e das instituições escolares; ao destaque do setor público na gestão da educação e dos seus recursos; à alternância nos postos de gestão das instituições escolares e à autonomia da escola na gestão dos recursos financeiros.

O quinto trabalho apresentado tem a professora Maria Dilnéia E. Fernandes, da UFMS, como autora e trata

10 tema da Conae 2014 foi "O Plano Nacional de Educação na articulação do Sistema Nacional de Educação: participação popular, cooperação federativa e regime de colaboração". 
de discutir a questão da valorização dos profissionais da educação. O artigo promove uma reflexão sobre a temática, considerando que na última década e meia, o Brasil deu materialidade a importantes mecanismos referentes à valorização docente, como as políticas de fundos e a lei do Piso Salarial Profissional Salarial (PSPN). A autora, ao final, chama-nos a atenção para o grande desafio que o país ainda tem para com a valorização docente, pois apesar daquela conjuntura, a lacuna entre o projetado e defendido pela política e pela legislação e a realidade efetivada, ainda é grande.

O professor da UnB e vice-presidente da Associação Nacional de Pesquisa em Financiamento da Educação Fineduca, Luiz Araújo, é o autor do artigo seguinte, que trata dos desafios do regime de colaboração no contexto do novo Plano Nacional de Educação, aprovado pela Lei Federal 13.005/2014. Tal leitura está diretamente conectada ao centro do debate da Conae 2014, como mencionado e o artigo traz uma importante contribuição, com reflexões que reconhecem de partida as dificuldades do arranjo organizacional do modelo federativo brasileiro. O texto de Araújo destaca que a lida com as desigualdades educacionais demanda, dentre outros aspectos, rever o papel da União no financiamento da educação, mas também e quiçá principalmente, implica no desenvolvimento de políticas redistributivas reguladas pelo governo central.

O artigo do professor João Monlevade, consultor do Senado Federal, apresenta uma leitura cuidadosa do disposto na Lei $n^{0}$ 13.005, de 25 de junho de 2014, que instituiu o novo Plano Nacional de Educação, em particular daqueles contidos na Meta 20, que trata do financiamento da educação brasileira. Professor Monlevade desenvolve uma reflexão importante sobre a proposição de vinculação do investimento em educação ao Produto Interno Bruto (PIB) e conclui analisando o contexto e as dificuldades para a implementação do projeto de financiamento da educação contido no PNE.

O oitavo artigo, de autoria de Daniel Cara, coordenador da Campanha Nacional pelo Direito à Educação, discute o Custo Aluno-Qualidade Inicial (CAQi) como uma importante ferramenta para enfrentar os desiquilíbrios gerados à educação básica pelo modelo federativo brasileiro, e evidencia como o CAQi se constitui em um dos principais pilares do novo PNE. Cara apresenta os marcos legais e localiza o CAQi neste contexto, e com isto defende este instrumento como uma garantia para o estabelecimento do padrão mínimo de qualidade definido na Constituição Federal.

O nono e último artigo é de autoria de Jokasta P.V. Ferraz, da Secretaria de Educação de Curitiba e Ângelo R. de Souza, da UFPR. Este trabalho analisa as emendas aprovadas ao documento referência da Conae 2014, na etapa municipal de Curitiba, no eixo VII - Financiamento da Educação. O trabalho dos autores busca destacar a relevância da atualização e constante vigilância no entorno deste temática, considerando que o financiamento é a expressão mais material da política educacional, uma vez que é ele que pode (ou não) efetivamente concretizar as decisões da política educacional no Brasil.

Nossa expectativa com esta edição do JPE é de contribuir com as reflexões sobre a proposição e alcance tanto da Conae como do PNE, por isto nosso esforço em fazer com que as ideias desenvolvidas pelo conjunto de autores aqui arrolados possam chegar tanto ao público acadêmico quanto à sociedade em geral, atingindo assim, além de pesquisadores, trabalhadores da educação, administradores de sistemas de ensino, policy makers e estudantes de cursos de licenciatura

Boa leitura a todos!

Os Editores 


\title{
Plano Nacional de Educação, Conferência Nacional de Educação e a construção do Sistema Nacional de Educação: dilemas e proposições
}

\begin{abstract}
National Education Plan, National Education Conference and the construction of the National Education System: dilemmas and propositions
\end{abstract}

Plan Nacional de Educación, Conferencia Nacional de Educación y la construcción del Sistema Nacional de Educación: dilemas y proposiciones

\section{Luiz Fernandes Dourado'}

\section{Resumo}

O texto situa a importância da Conferência Nacional de Educação - Conae e da ação articulada da sociedade civil e política com vistas à construção de políticas nacionais, enfatizando a importância da construção de um sistema de regulamentação da educação e instituição do Sistema Nacional de Educação, bem como indicando limites e questões que permeiam tais debates.

Palavras-chave: Conae; Sistema Nacional de Educação; Plano Nacional de Educação.

\begin{abstract}
The text places the importance of National Education Conference - CONAE and the coordinated action of civil and political society towards the construction of national policies, emphasizing the importance of building a regulatory system of education and the institution of the National Educatioan System, and the article finalizes showing the limits and issues that permeate such debates.
\end{abstract}

Keywords: Conae; National Education System; National Education Plan.

\section{Resumen}

El texto pone la importancia de la Conferencia Nacional de Educación - CONAE y de la acción coordinada de la sociedad civil y política en la construcción de las políticas nacionales, evidenciando la importancia de la construcción de un sistema de regulación de la educación y la institución del Sistema Nacional de Educación, asi como indica los límites y las cuestiones que impregnan este tipo de debates.

Palabras-clave: Conae; Sistema Nacional de Educación; Plan Nacional de Educación. 
A análise das políticas direcionadas à educação básica e superior no Brasil, por meio da análise da proposição de ações, programas e estratégias articulados pelos diferentes atores governamentais implica a apreensão, no feixe dessas proposições, dos limites e possibilidades à gestão destas políticas de modo a propiciar elementos para a compreensão dos processos de regulação e financiamento, bem como os arranjos institucionais que contribuem para a materialidade das políticas de gestão e organização educacionais no Brasil como políticas de Estado.

Nessa direção, a efetivação da II Conferência Nacional de Educação (Conae) cumpre um importante papel ao conclamar a particpação da sociedade. A Conae 2014 tem por objetivos específicos, definidos pelo Fórum Nacional de Educação: 1. Acompanhar e avaliar as deliberações da Conferência Nacional de Educação/2010, verificando seu impacto e procedendo às atualizações necessárias para a elaboração da Política Nacional de Educação e 2. Avaliar a tramitação e a implementação do Plano Nacional de Educação (PNE) na articulação do Sistema Nacional de Educação (SNE) e no desenvolvimento das políticas públicas educacionais.

Por essa razão, definiu-se a seguinte temática central da II Conae "O PNE na Articulação do Sistema Nacional de Educação: Participação Popular, Cooperação Federativa e Regime de Colaboração". Para avançar na problematização e deliberação dessa temática central foram aprovados sete eixos que compõem o documento referência a saber: Eixo I - O Plano Nacional de Educação e o Sistema Nacional de Educação: organização e regulação; Eixo II - Educação e Diversidade: justiça social, inclusão e direitos humanos; Eixo III - Educação, Trabalho e Desenvolvimento Sustentável: cultura, ciência, tecnologia, saúde, meio ambiente; Eixo IV - Qualidade da Educação: democratização do acesso, permanência, avaliação, condições de participação e aprendizagem; Eixo V - Gestão Democrática, Participação Popular e Controle Social; Eixo VI - Valorização dos Profissionais da Educação: formação, remuneração, carreira e condições de trabalho; Eixo VII - Financiamento da Educação: gestão, transparência e controle social dos recursos.

Os sete eixos temáticos se articulam em sintonia às concepções e proposições aprovadas na Conae 2010 e buscam avançar no enfrentamento de questões atinentes à relação educação e federalismo, planejamento e organicidade das políticas educacionais e de seu construto por meio de participação popular tendo por objetivo a construção de políticas de Estado para a educação nacional.

Aliado a esse processo é fundamental ressaltar, após longa tramitação, a aprovação do Plano Nacional de Educação por meio da Lei 13.005/14. O PNE avança em várias metas e estratégias, algumas delas resultantes do movimento social e sindical.

\section{A Conae como espaço de discussão e políticas educacionais}

A Conae, como espaço de discussão e deliberação coletiva, avança ao ser precedida por conferências municipais/intermunicipais, estaduais e do Distrito Federal realizados ao longo do ano de 2013 e que resultaram no documento base, que incorporou as deliberações das conferências estaduais propostas ao documento referência. Estima-se que esse processo de participação resultará em esforço nacional de reflexão e deliberação das questões educacionais relativas à educação cuja convergência efetivar-se-á por meio da realização da Conferência Nacional de Educação em Brasília em novembro de 2014. Este movimento de participação e deliberação contará com a participação de diferentes atores nas conferências municipais, estaduais e distrito federal e, também, na conferência nacional.

Espera-se que a conferência ao problematizar temáticas extremamente importantes possa contribuir com deliberações que avancem no sentido de busca de maior organicidade para as políticas para a educação, sinalizando para a necessária articulação entre temáticas gerais como: regulamentação do regime de colaboração entre os entes federados, efetivação de um sistema nacional de educação, rediscussão dos marcos das políticas de financiamento (com especial relevo para as questões atinentes à política de fundos 
destacando, neste contexto, o Fundeb) e defesa da ampliação dos recursos para a educação, regulamentação da gestão democrática, sistema nacional de avaliação, sistema nacional de formação de trabalhadores em educação e temáticas específicas como implementação e consolidação de mecanismos de participação e deliberação (modalidade de escolha de dirigente escolar com ênfase na eleição direta, participação estudantil, conselhos e órgãos de deliberação coletivos, etc), políticas articuladas para os diferentes níveis e modalidades para a educação básica e superior (envolvendo questões as mais diversas tais como as formas de organização e de gestão dos sistemas e instituições educativas, dinâmicas curriculares, jornada escolar, avaliação da aprendizagem, educação e diversidade, entre outros). Todas essas temáticas tratadas tendo por norte a educação, entendida como bem público, e enfatizando o papel do Estado na garantia de educação pública e gratuita de qualidade para todos contribuirá para o avanço do cenário educativo atual, fortemente marcado por desigualdades as mais diversas.

Neste contexto é oportuno situar os desafios propostas à Conae pela comissão organizadora:

- Elaborar conceitos, diretrizes e estratégias nacionais para a efetivação do Sistema Nacional Articulado de Educação coerente com a visão sistêmica da educação que reafirma a autonomia dos entes federados e avança na organicidade do PNE;

- Integrar todos os níveis, etapas e modalidades da educação escolar numa abordagem sistêmica, com vistas a consolidar os subsistemas nacionais articulados de planejamento e gestão, de financiamento, de avaliação e de formação (inicial e continuada) dos profissionais da educação;

- Dar início ao processo de institucionalização do Fórum Nacional de Educação (FNE), convocado e instalado pelo Ministério da Educação (MEC), enquanto instância de consulta, proposição, articulação, organização e acompanhamento da política nacional de educação e de coordenação permanente das conferências nacionais de educação, no âmbito do Sistema Nacional Articulado de Educação;

- Propor reformulações necessárias para que o planejamento de ações articuladas, torne-se a estratégia de implementação do PNE no âmbito do Sistema Nacional Articulado de Educação;

- Discutir as condições para a definição de políticas educacionais que promovam a inclusão, a diversidade, dentro de uma perspectiva orgânica e republicana da educação;

- Definir parâmetros e diretrizes para contribuir com a avaliação e a qualificação do processo de ensino e aprendizagem (Brasil, 2009a).

Frente a esses desafios, destaca-se, ainda o desdobramento do documento referência em documento base, indicando concepções norteadoras direcionadas à educação nacional e dialogando com a temática central e os eixos temáticos da Conae, resultantes dos debates e deliberações nas conferências municipais, estaduais/DF. Este movimento revela a fecundidade deste processo de participação, de grande importância na arena educacional brasileira, ao deslindar novos marcos para a proposição e materialização das políticas educacionais no país, ao mesmo tempo em que tal processo, em si mesmo, constituiu-se em dinâmica formativa dos diferentes atores que participaram e construíram a referida conferência.

\section{Sistema Nacional de Educação: desafios à educação brasileira}

Considerando as mudanças vivenciadas na educação brasileira, com destaque para a aprovação e promulgação da Constituição Federal de 1988, que garantiu uma concepção ampla de educação e sua inscrição como direito social inalienável, bem como a partilha de responsabilidade entre os entes federados e a vinculação constitucional de recursos para a educação, bem como, por meio da promulgação da Lei de Diretrizes e Bases da Educação Nacional (lei 9394/96) e, mais recentemente, após mais de 3 anos de tramitação a aprovação do Plano Nacional de Educação (Lei n. 13.005, de 25 de junho de 2014), faz-se necessária a busca de organicidade das políticas por meio da efetivação de um sistema articulado e descentralizado para a educação nacional. 
O SNE se coloca como espaço político da maior relevância sobretudo se considerarmos que o cenário educacional traduz a realidade desigual e combinada do estado brasileiro, com enorme descompasso entre os diferentes níveis e modalidades de educação no que diz respeito ao acesso e à permanência com qualidade social.

A discussão histórica sobre o SNE revela concepções e desafios à sua efetivação. Tais questões envolvem as várias aobrdagens dada a discussão sobre sistema na literatura, limites do pacto federativo efetivado num Estado patrimonial, a não regulamentação do regime de colaboração, a centralidade conferida às políticas governamentais em detrimento a políticas de Estado, entre outros.

Savianni (2008) apresenta, ainda, como limites ao sistema nacional: os obstáculos econômicos: a histórica resistência à manutenção da educação pública no Brasil; os obstáculos políticos: a descontinuidade nas políticas educativas; os obstáculos filosófico-ideológicos: a resistência no nível das ideias; os obstáculos legais: a resistência no plano da atividade legislativa.

Cury (2008, p. 1204), por sua vez, sinaliza que

Um sistema de educação supõe, como definição, uma rede de órgãos, instituições escolares e estabelecimentos - fato; um ordenamento jurídico com leis de educação - norma; uma finalidade comum - valor; uma base comum - direito.

Esses quatro elementos devem coexistir como conjunto, como conjunto organizado, como conjunto organizado sob um ordenamento, como conjunto organizado sob um ordenamento com finalidade comum (valor), como conjunto organizado sob um ordenamento com finalidade comum (valor) sob a figura de um direito.

Essa coexistência, pois, supõe unidade e diversidade, essa coexistência supõe unidade e diversidade sem antinomias (ausência de incompatibilidades normativas).

Segundo o autor, no Brasil

temos um organização da educação nacional e não um sistema nacional. Nacional é a educação, na forma federativa em que comparecem competências privativas, concorrentes e comuns dos entes federativos. A atual Constituição deu continuidade à tradição advinda do Ato Adicional de 1834 e dispôs pela pluralização dos sistemas (art. 211). Esses teriam uma articulação mútua organizada por meio de uma engenharia consociativa articulada por um regime de colaboração entre todos os entes federados até como modo de se evitar a dispersão e efetivar um regime federativo na educação. Um sistema nacional de educação teria que alavancar o papel da União com uma maior presença no âmbito da educação básica e no âmbito das redes privadas dos sistemas de ensino (CURY, 2008, p. 1199).

Neste cenário, o autor (CURY, 2008, p. 1204-1205) afirma que a proposição de um sistema nacional de educação, explicitamente formulado, gera várias perguntas:

1. Pode haver uma coordenação mais clara e mais direta pela União de modo que se exerçam as funções equalizadora e redistributiva?

2. Como aprimorar as competências dos sistemas de modo que se propicie um exercício harmônico do regime de colaboração sob a coordenação mais incisiva da União?

3. 0 sistema nacional propiciaria a melhoria dos resultados em relação à aprendizagem e à socialização de valores?

Ao problematizar tais questões, Cury (2008) enfatiza a importância da promoção de um autêntico federalismo em matéria educacional, a partir da divisão de responsabilidades previstas na Carta Magna.

Por sua vez, Savianni (2008) afirma, que em relação "à construção do Sistema Nacional de Educação propriamente dito, o ponto de referência é o regime de colaboração entre a União, os Estados/Distrito Federal e os Munic ípios, estabelecido pela Constituição Federal".

A implementação do regime de colaboração representa

uma repartição das responsabilidades entre os entes federativos, todos voltados para o mesmo objetivo de prover uma educação com o mesmo padrão de qualidade a toda a população brasileira. Assim, deixam de ter sentido os argumentos contra o sistema nacional baseados no caráter federativo que pressupõe a autonomia de estados e municípios.

0 regime de colaboração é um preceito constitucional que, obviamente não fere a autonomia dos entes federativos. Mesmo porque, (...), sistema não é a unidade da identidade, mas unidade da variedade. Logo, a melhor maneira de preservar a diversidade e as peculiaridades locais não é isolá-las e considerá-las em si mesmas, secundarizando suas interrelações. Ao contrário, trata-se de articulá-las num todo coerente, como elementos que são da mesma nação, a brasileira, no interior da qual se expressam toda a sua força e significado (SAVIANI, 2008). 
Por outro lado, é necessário reconhecer, segundo Dourado (2013), que o estado brasileiro é marcado por desigualdades sociais e assimetrias entre os entes federados e, por consequência, apresenta limites no horizonte de efetivação dos direitos sociais e na capilaridade das políticas, com destaque para as políticas educacionais.

A Constitiução Federal (CF) de 1988 sinaliza novas diretrizes para os direitos sociais no País, tendo por eixo um novo pacto federativo. Ela estruturou a lógica política que sinaliza para a autonomia e o regime de colaboração, a ser regulamentado entre os entes federados: união, estados, Distrito Federal e municípios. Tais questões não se dissociam de temas como reforma tributária, novo pacto federativo, efetiva descentralização das políticas (sem perder de vista a importância da coordenação nacional da União) que tenham por eixo a regulamentação do regime de colaboração.

A CF 1988, em seu artigo 23, parágrafo único, sinaliza para a necessidade de lei complementar para a fixação de normas de cooperação entre os entes federados. De acordo, com o parágrafo único, a "Lei complementar fixará normas para a cooperação entre a União e os Estados, o Distrito Federal e os Munic ípios, tendo em vista o equilíbrio do desenvolvimento e do bem-estar em âmbito nacional". O parágrafo foi alterado e passou a ter a seguinte redação: "Leis complementares fixarão normas para a cooperação entre a União e os Estados, o Distrito Federal e os Municípios, tendo em vista o equilíbrio do desenvolvimento e do bem-estar em âmbito nacional" (Redação dada pela Emenda Constitucional n 53, de 2006).

A concepção de equilíbrio e garantias de âmbito nacional sinaliza para o esforço federativo a ser efetivado. As bases da cooperação implicam, portanto, garantir as prerrogativas de autonomia dos entes federados e, paradoxalmente, a necessidade de mecanismos regulatórios direcionados ao bem-estar nacional. Tais questões traduzem uma tensão salutar entre a ação dos entes federados, incluindo a coordenação das políticas nacionais e os processos de descentralização.

Isso revela o esforço nacional para a construção de uma sociedade cujas políticas, programas e ações tenham como convergência o bem comum por meio da garantia de direitos sociais, o que requer um federalismo cooperativo, marcado pela descentralização e por padrões e diretrizes nacionais que assegurem o direito à educação com qualidade, o que implica combater as assimetrias regionais e sociais.

Nesse cenário, algumas questões foram problematizadas por Dourado (2013): de que federalismo falamos? Como apreender suas bases constitutivas num cenário marcado por assimetrias de toda ordem, inclusive regionais, estaduais, municipais e locais? Qual o papel da União e dos governos subnacionais para o atendimento aos direitos sociais, com destaque para a educação?

Essas questões nos remetem à forma de organização territorial, ao modelo de desenvolvimento e planejamento do estado brasileiro e aos limites estruturais à sua efetivação, requerendo, entre outras, uma ampla reforma tributária que contribua para a afirmação da autonomia dos governos subnacionais e, ao mesmo tempo, não prescinda do papel de coordenação nacional da União. No campo educacional, elas têm remetido à necessidade de instituição de um SNE e de construção de planos decenais de educação como políticas de Estado, além das questões relativas ao regime de colaboração e cooperação entre os entes federados, sem negligenciar, paradoxalmente, as tensões e desafios que demarcam a definição das competências e o horizonte de suas autonomias.

Assim, entendo que a autonomia dos entes federados é ratificada, mas distingue-se de soberania, à medida que é definida nos termos da CF. Isso enseja uma reflexão ampla sobre a relação entre coordenação e autonomia, bem como a devida compreensão dos termos da CF, para a atuação dos entes federados e para a efetivação do pacto federativo brasileiro.

Essa discussão nos remete à concepção de autonomia regulada, ou seja, a autonomia dos entes federados não é sinônimo de soberania mas resultante da efetivação de bases de convergência demarcadas pela tensão entre as competências da União, sobretudo as privativas, e as competências comuns e concorrentes da união, estados, Distrito Federal e municípios. 
Tais processos, considerando as emendas à CF, demonstram a necessidade de estabelecer leis complementares que normatizem o regime de colaboração entre os entes federados. A CF, em seus artigos 23 e 211, revigorados pela EC n59/2009, avança no campo educacional, prevendo, inclusive, que as competências dos entes federados e a organização de seus sistemas de ensino devem se efetivar por meio de regime de colaboração.

Sobre o federalismo brasileiro há, portanto, algumas convergências, com realce para o entendimento de sua tipologia inédita, ao incluir os municípios com prerrogativas de autonomia e por caracterizar-se pelo binômio centralização/descentralização, assumindo importantes contornos na educação. Cruz (2012) sinaliza que o padrão de federalismo desenvolvido no Brasil também condiciona e influencia o setor educacional, o que é revelado pelas relações que a União estabelece com estados, Distrito Federal e municípios na gestão das políticas educacionais, embora a própria Constituição Federal defina parâmetros e responsabilidades, inclusive no financiamento da educação.

No campo educacional, a superação desses limites tem ensejado a instituição do SNE, planos decenais (nacional, estaduais/DF e municipais) com vistas a garantir maior organicidade no acesso à educação em todos os níveis, etapas e modalidades, sobretudo na garantia à educação básica obrigatória (quatro a 17 anos). Todos eles revelam um descompasso entre o marco jurídico normativo e os processos efetivos na relação entre os entes federados, o que ratifica a necessária regulamentação do regime de colaboração, sem prejuízo do estabelecimento de relações de cooperação, onde haja uma relação proporcional entre competências e capacidade financeira, o que, no caso brasileiro, ensejará reformas de ordem estrutural, incluindo a reforma tributária.

Nessa direção, o documento da Conae/2014 afirma que a organização e regulação da educação nacional deve garantir a articulação entre acesso, permanência², valorização dos profissionais, gestão democrática, padrão de qualidade, piso salarial profissional por meio dos seguintes princípios: I - igualdade de condições para 0 acesso e permanência na escola; II - liberdade de aprender, ensinar, pesquisar e divulgar o pensamento, a arte e o saber; III - pluralismo de ideias e de concepções pedagógicas, coexistência de instituições públicas e privadas de ensino; IV - gratuidade do ensino público em estabelecimentos oficiais; $V$ - valorização dos profissionais da educação escolar, garantidos, na forma da lei, planos de carreira, com ingresso exclusivamente por concurso público de provas e títulos aos das redes públicas (EC n 53/2006); VI - gestão democrática do ensino público, na forma da lei; VII - garantia de padrão de qualidade; VIII - piso salarial profissional nacional para os profissionais da educação escolar pública, nos termos de lei federal (EC n53/2006). Parágrafo único. A lei disporá sobre as categorias de trabalhadores considerados profissionais da educação básica e sobre a fixação de prazo para a elaboração ou adequação de seus planos de carreira, no âmbito da União, dos estados, do DF e dos municípios (EC n0 53/2006).

E muitas destas proposições se encontram dispostas no Plano Nacional de Educação, em maior ou menor grau.

O SNE, e na sua estruturação, a efetiva definição de formas de colaboração entre os sistemas de ensino e a fixação de normas de cooperação entre os entes federados são fundamentais para a garantia da universalização da educação obrigatória de quatro a 17 anos. Isso pressupõe um tensionamento à diferenciação que marca o sistema federativo, bem como a relação descentralização e centralização como caminho fértil para a garantia do direito à educação para todos o que se reafirma no incremento de ações interfederativas construídas de forma participativa o que caracterizaria as bases de uma concepção e lógica de gestão pautada pela interdependência.

Segundo Dourado (2013), outra definição crucial para as políticas e para o planejamento da educação no Brasil foi enfatizada na redação da EC n59/2009, ao indicar que uma lei específica estabeleceria o PNE, de duração decenal, com o objetivo de articular o SNE, em regime de colaboração entre os entes federados, definindo diretrizes, objetivos, metas e estratégias de implementação, para assegurar a manutenção e desenvolvimento do ensino em seus diversos níveis, etapas e modalidades, por meio de ações integradas dos poderes públicos das diferentes esferas federativas, incluindo o estabelecimento de meta de aplicação de recursos públicos em educação como proporção do produto interno bruto (PIB). A efetivação do SNE tem como pressuposto

2 Permanência entendida numa acepção ampla, envolvendo a garantia de aprendizagem e conclusão com sucesso pelo estudante. 
o disposto da CF/1988, segundo o qual compete privativamente à união legislar sobre diretrizes e bases da educação nacional (art. 22). A aprovação do PNE avança neste contexto, pois aprova a criação do SNE em dois anos, o que vai requerer proposições concretas sobre a sua materialidade, composição, atribuições e objetivos e, certamente, como tais processos vão interferir no campo das políticas e gestão da educação.

Nesse cenário, é fundamental avançar na problematização das questões teórico-práticas em que se colocam o regime de colaboração e a instituição do Sistema Nacional de Educação.

A compreensão das bases de instituição do SNE no documento referência da Conae 2014 é singular, pois este sistema

é entendido como expressão institucional do esforço organizado, autônomo e permanente do Estado e da sociedade, compreendendo os sistemas de ensino da União, dos estados, do Distrito Federal e dos municípios, bem como outras instituições públicas ou privadas de natureza educacional (BRASIL, 2013).

\section{Considerações finais}

Ao longo do texto situamos a importância da Conferência Nacional de Educação e da ação articulada da sociedade civil e política com vistas à construção de políticas nacionais. Nessa direção, foi enfatizado a importância da construção de um sistema de regulamentação da educação, a instituição do Sistema Nacional de Educação, bem como foram indicados limites e questões que permeiam tais debates.

Todas essas questões se articulam às condições objetivas da população, em um país historicamente demarcado por forte desigualdade social, revelada nos indicadores sociais preocupantes e que, nesse sentido, carece de amplas políticas públicas, incluindo a garantia de otimização nas políticas de acesso, permanência e gestão, com qualidade social, na educação básica e superior.

Assegurar condições políticas e de gestão para a instituição do SNE, incluindo o envolvimento e a participação da sociedade na formulação, implementação das políticas, programas, bem como a melhoria da educação nos diferentes níveis e modalidades, é fundamental e se articula ao esforço preconizado pela conferência nacional ao enfatizar a articulação entre a construção do SNE, o PNE, a gestão democrática, diversidade e a qualidade social como eixos a serem efetivamente consolidados por meio de processos amplos de participação.

Nessa direção, um dos grandes desafios à educação nacional refere-se à efetiva articulação entre os entes federados com vistas à construção de um SNE que garanta diretrizes nacionais comuns, políticas articuladas e universais. Assim, ao Sistema Nacional de Educação caberá o papel de articulador, normatizador, coordenador geral da educação nacional, por meio de um fórum nacional, visando garantir finalidades, diretrizes e estratégias educacionais comuns e, ao mesmo tempo, as especificidades próprias de cada um. Assim, o esforço de construção do SNE articula-se ao desafio de avaliação e proposição de novo PNE, como expressão de política de Estado para a área.

Por isso, a Conae cumpre um importante papel político ao problematizar a necessidade do estabelecimento de diretrizes para a instituição de um sistema nacional de educação que possibilite a ação articulada entre os entes federados, a efetivação de planejamento sistemático, que, após avaliar o conjunto de ações, programas e planos em desenvolvimento, contribua para o estabelecimento de políticas de Estado, programas e ações que garantam organicidade entre as políticas educacionais no país, envolvendo os diferentes órgãos de gestão educacional (MEC, sistemas de ensino e instituições) e, ainda, destacando a necessária mediação entre o Estado, demandas sociais e o setor produtivo, de modo a se avançar na superação do cenário educacional, historicamente demarcado pela fragmentação ou superposição de ações e programas, pela centralização das políticas de organização e gestão da educação básica no país.

Tais sinalizações remetem à busca da superação dos atuais limites estruturais à lógica político-pedagógica dos processos de proposição e materialização das políticas educacionais, fortemente marcados pela gestão centralizada. 
Nessa direção, o investimento em educação, tendo a qualidade como parâmetro de suas diretrizes, metas e ações e conferindo a essa qualidade uma dimensão sócio-histórica e, portanto, inclusiva, é outro importante desafio para o país. A busca por melhoria da qualidade da educação, neste contexto, exige medidas não só no campo do ingresso e da permanência, mas requer ações que possam reverter a situação atual, o que pressupõe, por um lado, identificar os condicionantes das políticas e gestão e, por outro, refletir sobre a construção de estratégias de mudança do quadro atual.

\section{Referências}

ABICALIL, C.A. O federalismo e o Sistema Nacional de Educação: uma oportunidade fecunda. Revista Retratos da Escola, Brasília, v.6, n.10,p.5-6, jan./jun.2012, p.21-37. Disponível em htpp//www.esforce.org.br

BRASIL. Ministério da Educação. Construindo o sistema nacional articulado de educação: o Plano Nacional de Educação, diretrizes e estratégias de ação. Documento final da CONAE 2010. Brasília, DF: MEC, 2010a. Disponível em: http://conae.mec.gov.br/images/stories/pdf/pdf/documetos/documento_final.pdf. Acesso em: março. 2013.

Presidência da República. Casa Civil. Lei 13.005/2014 que Aprova o Plano Nacional de Educação para o decênio 2014-2024 e dá outras providências. Disponível em: http://www.planalto.gov.br/ccivil_03/_ Ato20112014/2014/Lei/L13005.htm. Acesso em: julho 2014.

Ministério da Educação. Portaria n 1.407, de 14 de dezembro de 2010. Institui o Fórum Nacional de Educação - FNE. Diário Oficial da União, Brasília, DF, 16 dez. 2011.

Ministério da Educação. O PNE na articulação do sistema nacional de educação: participação popular, cooperação federativa e regime de colaboração. Documento-referência da CONAE 2014. Brasília, DF: MEC, 2012. Disponível em: <http://fne.mec.gov.br/images/pdf/documentoreferenciaconae2014versaofinal.pdf>. Acesso em: março. 2013.

CURY, C.R.J. Os desafios da Construção de um Sistema Nacional de Educação. Disponível em http://conae. mec.gov.br/images/stories/pdf/jamil_cury.pdf, acesso em 14.04.13

A questão federativa e a educação escolar. In. Educação e federalismo no Brasil: combater as desigualdades, garantir a diversidade. Brasília: UNESCO, 2010, p 149-.

CRUZ, R. E. Federalismo e educação: um pacto a se rever. Revista Retratos da Escola, Brasília, v.6, n.10, jan./jun.2012, p.65-78. Disponível em htpp//www.esforce.org.br.

DOURADO, L.F. Avaliação do Plano Nacional de Educação 2001-2009: questões estruturais e conjunturais de uma política. Educação e Sociedade, Campinas, v. 31, n. 112, p. 677-705, jul./set. 2010.

Sistema Nacional de Educação, Federalismo e os obstáculos ao direito à educação básica. Educação e Sociedade., Set 2013, vol.34, no.124, p.761-785. ISSN 0101-7330.

Avaliação do Plano Nacional de Educação 2001-2009: questões estruturais e conjunturais de uma política. Educação e Sociedade., Set 2010, vol.31, no.112, p.677-705. ISSN 0101-7330

(Org.). Plano Nacional de Educação (2011-2020): avaliação e perspectivas. 2. ed. Goiânia: UFG; Belo Horizonte: Autêntica, 2011

. Financiamento da educação no Brasil: aportes teóricos e a construção de uma rede de pesquisadores.

In. GOUVEIA, A.B.; SOUZA, A.R. Conversas sobre financiamento da educação no Brasil. Curitiba: Ed. Da UFPR, 2006, p.27-40.

; AMARAL, N.C. Financiamento e gestão da Educação e o PNE 2011-2020: avaliação e perspectivas. In. DOURADO, L.F. (Org.). Plano Nacional de Educação (2011-2020): avaliação e perspectivas. 2. ed. Goiânia: UFG; Belo Horizonte: Autêntica, 2011, P.285-315.

A conferência nacional de educação: construção democrática de políticas de estado. Disponível em 
http://conae.mec.gov.br/images/stories/pdf/texto\%20chagas\%20alterado25.03.pdf. Acesso em 20.04.13

SAVIANNI, D. Sistema de Educação: Subsídios para a Conferência Nacional de Educação. Disponível em http://conae.mec.gov.br/images/stories/pdf/conae_dermevalsaviani.pdf. Acesso em 20.04.13.

Sistema Nacional de Educação: Conceito, Papel Histórico e Obstáculos para sua construção

no Brasil. MG, Caxambú : 31ª Reunião Anual da ANPEd, 2008. Trabalho preparado por solicitação do GT-05: Estado e Política Educacional. 


\title{
Diversidade, educação e relações étnico- raciais na Conae-PR ${ }^{1}$
}

\section{Diversity, education and ethnic-racial relations in Conae-PR}

Diversidad, educación y relaciones étnico-raciales en la Conae-PR

\author{
Paulo Vinícius Baptista da Silva² \\ Rosa Amália Espejo Trigo ${ }^{3}$ \\ Lucimar Rosa Dias ${ }^{4}$
}

\section{Resumo}

Este artigo focaliza a relação entre diversidade e educação tratada na Conferência Estadual de Educação do Estado do Paraná (Conae-PR). Compreende-se a diversidade a partir das propostas vindas dos movimentos sociais e outras esferas do espaço social como sendo um fator importante para o reconhecimento das diferenças e a superação das desigualdades. Foram definidos como objeto de análise o documento referência da II Conferência Nacional de Educação - Conae e as propostas para a Conae -PR organizadas no Caderno de Emendas. A análise parte de uma discussão sobre o conceito de diversidade e suas expressões nos documentos e converge para as relações étnico-raciais, em especial as proposições dirigidas para o estabelecimento de igualdade étnico-racial e para buscar equalizar os resultados educacionais dos grupos de raça/cor brancos(as) e negros(as). No processo da análise revela-se um alongamento da agenda da diversidade, que se estendem nos diversos eixos, nas metas e estratégias para especificações que atendem a educação do campo, quilombolas, escolas indígenas, pessoas com deficiências, relação étnico-raciais, relações de gênero e orientação sexual. Evidenciase um debate muito intenso de posições inclusive antagônicas, que acabaram retirando propostas de promoção de igualdade étnico-racial. No entanto o que prevalece é a reafirmação e aumento das políticas educacionais voltadas para as minorias, em uma tendência que busca combinar políticas focais com avanços das políticas universalistas.

Palavras chave: Política educacional; Diversidade; Movimentos sociais; Movimentos negros; Relações étnico-raciais.

\section{Agradecemos o financiamento do CNPQ e da Fundação Araucária.}

2 Doutor em Psicologia Social, professor e pesquisador do Núcleo de Estudos Afro-Brasileiros (NEAB) e do Programa de Pós-Graduação em Educação (PPGE) da Universidade Federal do Paraná (UFPR). E-mail: paulovbsilva@uol.com.br

3 Doutora em Psicologia Social pela Pontifícia Universidade Católica de São Paulo (PUC-SP), pesquisadora do Núcleo de Estudos Afro-Brasileiros (NEAB) e pós-doutoranda no Programa de Pós-Graduação em Educação da Universidade Federal do Paraná (UFPR). E-mail: respejo@hotmail.com

4 Doutora em educação, professora e pesquisadora do Programa de Pós-Graduação em Educação (PPGE) da Universidade Federal do Paraná (UFPR). E-mail: lucimar_dias@uol.com.br 


\begin{abstract}
This article focuses in the relation between diversity and education presented in the State Education Conference of Paraná (Conae -PR). Diversity is understood according to the proposals emerging from social movements and other spheres of the social space, being an important factor for recognizing differences and overcoming inequalities. Two documents were defined as objects of analysis, the II National Education Conference - Conae reference document and the proposals for Conae -PR, organized in the Summary of Amendments. The analysis stems from a discussion on the concept of diversity, how it is expressed in the documents, and converges to ethnic and race relations, particularly in the propositions aiming at establishing ethnic and race equality and leveling education outcomes between white and black race groups. The analysis process brings out a much wider diversity agenda, with several axles stretching out, regarding goals and strategies for specifications that attend to country education, quilombolas (marrons descents), indigenous schools, people with disabilities, ethnic and race relations, gender relations and sexual orientation. There is a clear and very intense discussion, including even antagonistic positions, that ends up withdrawing proposals promoting ethnic and race equality. However, the reaffirmation and increase of minorities prevails, in a tendency that looks to combine focal policies with advancements in universalizing policies.
\end{abstract}

Keywords: Educational policy; Diversity; Social movements; Black movements; Race relations.

\title{
Resumen
}

Este artículo se centra en la relación entre la diversidad y la educación tratados en la Conferencia de la Educación del Estado de Paraná (Conae-PR). Se entiende la diversidad de las propuestas provenientes de Ios movimientos sociales y otras esferas del espacio social como un factor importante para el reconocimiento de las diferencias y superación de las desigualdades. Se definieron como objeto de análisis el documento de referencia de la II Conferencia Nacional de Educación - Conae y propuestas para la Conae-PR organizado en las enmiendas. En el análisis del debate sobre el concepto de la diversidad y sus expresiones en los documentos converge a las relaciones étnico-racial, en particular las propuestas dirigidas al establecimiento de la igualdad étnica-racial y trata de igualar los resultados educativos de los grupos raciales/de color blanco(as) y negro(as). En el proceso de análisis, el texto demuestra que hay un proceso de alargamiento de la diversidad, que se extiende a lo largo de los ejes, objetivos y estrategias con las especificaciones que cumplen la educación nel campo, quilombolas, escuelas indígenas, personas con discapacidad, relación étnico-racial, relaciones de género y de orientación sexual. Pero, lo que ha prevalecido fue un debate muy intenso incluso con posiciones antagónicas, que finalmente se retiraron las propuestas para promover la igualdad étnica y racial. Sin embargo, lo que finalmente prevalece es la reafirmación y el aumento de las políticas educativas dirigidas a las minorías, en una tendencia que busca combinar las políticas focales con los avances en las políticas universales.

Palabras-clave: Política educativa; Diversidad; Movimientos sociales; Movimientos Negros; Relaciones etnico-raciales. 
Este artigo focaliza a relação entre diversidade e educação tratada na Conferência Estadual de Educação do Estado do Paraná (Conae-PR), ocorrida em setembro de 2013 no processo preparatório para a II Conferência Nacional de Educação - Conae ${ }^{5}$. Foram definidos como objeto de análise o documento referência da II Conae (FNE, 2013) e as propostas para a Conae -PR organizadas no Caderno de Emendas (FEE, 2013).

A compreensão é que os documentos construídos de forma coletiva por diversos atores sociais são reveladores de diferentes e por vezes divergentes pontos de vista, de interesses também conflitantes quando não contraditórios, de acordos possíveis nos processos coletivos de discussão. Um foco de interesse são as possibilidades de participação dos movimentos sociais nesses processos democráticos e a efetividade de suas proposições.

A análise parte de uma discussão sobre o conceito de diversidade e suas expressões nos documentos e converge para as relações étnico-raciais, em especial as proposições dirigidas para o estabelecimento de igualdade étnico-racial e para buscar equalizar os resultados educacionais dos grupos de raça/cor brancos(as) e negros(as).

A discussão tem como referência o conceito de racialização, ou seja, raça compreendida como uma construção que opera socialmente para manter hierarquias entre grupos populacionais classificados, por características de aparência ou não. Tais classificações sociais definem processos de diferença de acesso a recursos materiais e simbólicos na sociedade. No Brasil temos dados para afirmar com segurança que a população negra, os povos indígenas e os povos ciganos são racializados. Porém, em função dos limites do artigo, o foco da análise recai sobre as propostas referentes à população negra e de forma bastante sintética, mencionamos as que se destinaram aos povos ciganos.

Para tal, organizamos os argumentos em três diferentes partes, a primeira analisa as proposições para a diversidade que constam no documento-referência da II CONAE, com maior detalhamento das proposições do eixo II, intitulado "Educação e Diversidade"; a segunda dá continuidade à análise, mas focalizando nas proposições dos demais eixos; a terceira volta o foco novamente para o eixo Educação e Diversidade nas proposições para a Conae do Paraná, explorando na análise em especial as tensões reveladas por proposições contraditórias e divergentes.

\section{A diversidade no documento referência da II Conae}

Antes de chegar na discussão das proposições passemos pelo documento-referência da II Conae. Uma primeira questão é a constatação do aumento de relevância que as proposições sobre "diversidade" ganharam nesse documento, em relação ao da I Conae 20106. Laprane e Prieto (2010), apontaram que nesta Conferência foi possível constatar um aumento de visibilidade dos temas referentes a temática no eixo VI - Justiça Social, Educação e Trabalho: Inclusão, Diversidade e Igualdade o que acabou por produzir formulações de metas que contemplaram aspectos relativos aos temas evidenciados no eixo porém, alertam:

Pode-se, sem muito auxílio analítico, antever que a discussão de cada proposta dos referidos temas foi absolutamente prejudicada pela própria organização do eixo. Assim, muitas propostas foram referendadas por uma dinâmica movida muito mais pelo sentido de reconhecimento do processo de construção das reivindicações de cada segmento representado nas plenárias, do que pela discussão aprofundada de algumas destas (LAPRANE, PRIETO, p. 912, 2010).

5 Que inicialmente estava prevista para ocorrer em 2014, mas foi adiada pelo Ministério da Educação, resultando em críticas diversas dos movimentos sociais e das associações científicas da área da educação.

6 A composição do Fórum Nacional de Educação permaneceu com uma única "representação dos Movimentos de Afirmação da Diversidade" com tanto titular quanto suplente do movimento social negro. Acresceu-se a representação da Comissão Nacional de Educação Escolar Indígena (CNEEI). A outra novidade ficou na "equipe de consultores da Comissão Especial de Monitoramento e Sistematização do FNE", coordenada pelo pesquisador Luiz F. Dourado da UFG, a equipe tem 3 outros pesquisadores da mesma universidade, 2 da UNB, 1 da UFMG e 1 da UFPE. Além de composta por pesquisadores hegemonicamente da região Centro-Oeste, uma novidade em relação aos processos nacionais nos quais pesquisadores do sudeste, especialmente de São Paulo assumem os postos mais relevantes, a comissão contou como especialista sobre diversidade com a pesquisadora Nilma L. Gomes, ativista do movimento negro acadêmico e professora da UFMG. 
Constatamos na II Conae algumas mudanças qualitativas em relação ao que as autoras apontam, visto que de seis eixos da I Conae passaram a sete e o tema da diversidade que estava localizado no eixo VI, e dava a impressão de ser apenas um anexo ao tema principal, cujo título realçava dois campos de estudo bastante consolidados na educação brasileira, "justiça social" e "educação e trabalho", mas nem sempre permeáveis a questões trazidas pela agenda da diversidade.

Na II Conae o eixo II foi intitulado "Educação e Diversidade: justiça social, inclusão e direitos humanos", no qual fica explícito o ganho de relevância, menos pela mudança de numeração do eixo, mais pela redação que coloca o tema em ênfase. Verificadas as redações dos eixos da II Conae, pode-se afirmar que os dois temas que ganharam em importância em relação aos eixos da I Conae foram a "gestão democrática" e a "diversidade" e foi possível constatar que propostas dispersas nos diversos eixos se relacionam a tópicos específicos da "diversidade" dos quais destacaremos ao longo do texto os referentes à igualdade étnico-racial.

A apresentação do eixo II traz uma série de elementos significativos para a discussão da diversidade: 0 tema Educação e diversidade: justiça social, inclusão e direitos humanos constitui 0 eixo central da educação e objeto da política educacional. Diz respeito à efetivação da educação pública democrática, laica e com qualidade social nas instituições educativas de todos os níveis, etapas e modalidades.

A diversidade, como dimensão humana, deve ser entendida como a construção histórica, social, cultural e política das diferenças que se expressa nas complexas relações sociais e de poder.

Uma política educacional pautada na diversidade traz para o exercício da prática democrática a problematização sobre a construção da igualdade social e as desigualdades existentes. Esta construção pressupõe o reconhecimento da diversidade no desenvolvimento sócio histórico, cultural, econômico e político da sociedade.

No contexto das relações de poder, os grupos humanos não só classificam as diferenças como, também, hierarquizam-nas, colocandoas em escalas de valor e subalternizam uns em relação a outros. Nesse processo, as diferenças são descaracterizadas e transformadas em desigualdades.

Historicamente, os movimentos feminista, indígena, negro, quilombola, LGBT7, ambientalista, do campo, das pessoas com deficiências, dentre outros, denunciam as ações de violência, desrespeito aos direitos humanos, intolerância religiosa e toda forma de fundamentalismo, racismo, sexíssimo, homofobia, lesbofobia, transfobia e segregação, que incidem sobre os coletivos sóciorraciais considerados diversos (FNE, 2013, p. 28).

A afirmação no início do eixo II de que a diversidade é o carro chefe da perspectiva da inclusão e dos direitos humanos e se constitui em "tema central da educação e objeto da política educacional" dá fundamento para a interpretação de que a diversidade passou a ocupar um lugar de maior relevância na II Conae, desde seu processo inicial. Na frase seguinte do documento-referência a educação pública é projetada como "laica, democrática e com qualidade social", sendo que a adjetivação da qualidade como "qualidade social" responde aos anseios de muitos dos propositores da II Conae, do Fórum Nacional de Educação (FNE) e equipe de consultores. Na parte seguinte, o texto oferece uma definição de diversidade, afirmando que a diversidade se expressa nas relações sociais e de poder; expressa os complexos processos sociais de construção e tratamento das diferenças; envolve a crítica às hierarquias que estabelecem as diferenças como desigualdades; envolve a luta dos "movimentos feministas, indígena, negro, quilombola, LGBT, ambientalista, do campo, das pessoas com deficiência, entre outros" (FNE, 2013).

Tal perspectiva se coaduna com as preocupações já apontadas por Rodrigues e Abramowicz (2011, p.245), que alertam sobre a necessidade de qualificar o discurso sobre diversidade, para que seu uso não sirva ao "esvaziamento e/ou de apaziguamento das diferenças", mas possa ser um exercício crítico de compreensão sobre as diferenças

7 A sigla LGBT se refere a lésbicas, gays, bissexuais, travestis, transexuais e transgêneros. 0 uso do termo foi aprovado durante conferência realizada em Brasília, em 2008, e substituiu a sigla GLS (gays, lésbicas e bissexuais), utilizada até então para representar a diversidade sexual. Fonte: <http:/l www12.senado.gov.br/noticias/entenda-0-assunto/lgbt> Acesso em 15 Jun, 2014. 
problematizando as relações hierarquizadas e as desigualdades sociais. E também do já problematizado por Pierucci (1999) quando aponta que o discurso da "diferença" pode ser apropriado por conservadores, de forma a atuar mais para a conservação, apaziguamento e esvaziamento das diferenças que para sua crítica.

O que se verifica no texto do eixo II é um esforço para fazer um caminho distinto dos perigos que os autores supracitados estão indicando, busca-se uma definição ampla de diversidade articulada a luta de movimentos sociais que são múltiplos (têm configurações e pautas muito diversas) mas têm em comum a luta pelo combate às desigualdades a que foram historicamente submetidos. Concorre para isso a explicitação de oito movimentos sociais que estão citados no item e articulados em torno da pauta, ou seja, não é somente uma diversidade abstrata e generalizante, mas a luta por igualdade dos movimentos "feministas, indígena, negro, quilombola, LGBT, ambientalista, do campo, das pessoas com deficiência, entre outros" (FNE, 2013).

O texto faz a ressalva em relação ao tratamento generalizante, no que diz respeito aos direitos humanos: "A concepção de direitos humanos, numa perspectiva emancipatória, se contrapõe à compreensão abstrata de humanidade ainda presente em muitos discursos, políticas e práticas de educação meramente regulatórios, que mantêm suposta neutralidade frente à luta pela inclusão social” (FNE, 2013, p. 29). Além disso, amplia e qualifica a atuação dos movimentos sociais:

Os coletivos políticos, tais como os movimentos negro, quilombola, indígena, de mulheres, LGBT, ambientalista, povos do campo, povos da floresta e povos das águas ${ }^{6}$. Das comunidades tradicionais, de inclusão das pessoas com deficiência, dentre outros, afirmam o direito à diferença, instigam a adoção de políticas públicas específicas, fazendo avançar, na sociedade, a luta política pelo reconhecimento, pela luta contra 0 racismo e pela valorização da diversidade. Os movimentos sociais contribuem para a politização das diferenças, da identidade e as colocam no cerne das lutas pela afirmação e garantia dos direitos. Ao atuarem dessa forma, questionam o tratamento dados pelo Estado à diversidade, cobram políicas públicas e democráticas e a construção de ações afirmativas destinadas aos grupos historicamente discriminados (FNE, 2013, p. 29).

O posicionamento que o texto reflete sobre a diversidade não deixa dúvida quanto ao seu caráter crítico e ao compromisso político dessa perspectiva, pois reconhece os protagonistas dessa luta identificando-os e também qualifica o papel do Estado para que ao reconhecer a diversidade, produza mecanismos que operem na construção de políticas públicas que alcancem os grupos específicos para que atinjam a igualdade política e econômica.

A ressalva sobre a concepção de diversidade ter validade para o texto base do eixo II, mas não para todo o documento, relaciona-se com o reconhecimento que este tipo de documento faz parte de um processo amplo de negociação política e de acordos possíveis, sendo expressão de vozes de diferentes atores sociais. Portanto, o esperado não é a organicidade ou coerência ao longo de todo o documento, mas as contradições e inconstâncias que caracterizam os processos de amplas negociações sociais. No caso do documento-referência da II Conae, a redação inicial foi feita pela equipe de consultores e após foi pormenorizadamente discutida pelo Fórum Nacional de Educação. Então as vozes que estão no texto são fruto dos embates e acordos entre os representantes dos movimentos sociais, dos membros governamentais e dos pesquisadores da área de educação que formaram a equipe de consultores.

\section{Diversidade e diversidade étnico-racial nos demais eixos do documento-referência da II Conae}

Para além do eixo II, a "agenda da diversidade" em geral e a "agenda da igualdade étnico-racial" em particular galgaram espaços nos diversos outros eixos que compuseram o documento-referência. O eixo I versa sobre o Sistema Nacional de Educação (SNE) e o Plano Nacional de Educação (PNE) e propõe que ambos devem promover, reconhecer e valorizar a diversidade. Nesse eixo que tem uma importância central, pois busca ser organizador do sistema e orientador do PNE, função precípua da Conae, a manifestação sobre a diversidade é ampla e toma parte nas diretrizes expressas do eixo compondo os fundamentos do mesmo e afirmando a necessária promoção da educação do campo, quilombola, escolar indígena, das pessoas com deficiência, das relações étnico-raciais, de gênero e de orientação sexual. 
Nas proposições e estratégias encontramos também uma pauta ampla, com indicações e articulações diversas envolvendo a "promoção da diversidade étnico-racial", "de gênero e orientação sexual"; "diversidade, educação ambiental e inclusão"; "direitos humanos"; e "diversidade étnico-racial", "Fórum de Educação Escolar Indígena, Fórum de Educação do Campo, Fórum de Educação Inclusiva, Fórum de Educação em Direitos Humanos, Fórum de Educação de Jovens e Adultos, Fórum de Educação Profissional, Fórum LGBT, dentre outros". A pauta mantêm-se ampla, a diversidade na maior parte das vezes tem determinadas minorias sociais explicitadas, ao mesmo tempo em que um detalhamento maior de pautas e de grupos minoritários, especialmente dos novos movimentos sociais (povos quilombolas, povos da águas, povos das florestas) ainda não surge no texto.

No eixo III (Educação, Trabalho e Desenvolvimento Sustentável: Cultura, Ciência, Tecnologia, Saúde, Meio Ambiente), observa-se uma série de proposições para a EJA e as diretrizes do eixo têm como um dos princípios considerar a "diversidade cultural". Os movimentos negros e indígenas tem, ao longo das décadas, realizado a crítica aos discursos que enaltecem a diversidade cultural brasileira, mas que operam para desconsiderar as desigualdades sociais a que tais grupos são submetidos e operam para encobrí-las ao lado de uma perspectiva mas ampliada, isto é, politicamente comprometida com igualdade como se pode conferir suas pautas e seu reconhecimento. Por outro lado, uma das proposições do eixo se referiu aos povos indígenas e povos tradicionais, e nas proposições 2.4 e 8.21 do eixo a diversidade cultural se apresenta da seguinte forma:

2.4. Garantir o respeito e valorização do meio-ambiente, contexto e diversidade cultural, igualdade de gênero, raça, étnica, orientação sexual e geracional. (FNE, 2013, p. 43).

8.19. Desenvolver intersetorialmente políticas públicas educacionais de valorização sustentabilidade socioambiental, diversidade regional, biodiversidade, diversidade cultural, promoção da igualdade de gênero, raça, etnia e orientação sexual, identidade de gênero e idade (FNE, 2013, p. 50).

Temos, portanto, um exemplo de redação que parece buscar a integração de duas perspectivas uma sobre a "diversidade cultural" e outra sobre a necessidade de promover a igualdade para grupos específicos.

O eixo IV (Qualidade da Educação: democratização do acesso, permanência, avaliação, condições de participação e aprendizagem) coloca as políticas afirmativas no foco, especialmente no que se refere a políticas de acesso. Analisaremos com mais detalhe o tema, relacionando com as proposições da Conae-PR. A pauta ampla da diversidade entra com proposições para grupos diversos: populações do campo, 25\% mais pobres, negros/as, indígenas, mulheres, LGBT com uma meta específica para acesso e permanência de travestis e transexuais no ensino fundamental e médio, quilombolas, povos da floresta, povos do campo, povos das águas e populações tradicionais. Uma das metas propunha um objetivo bastante audacioso:

Elevação da escolaridade média da população de 18 a 29 anos, de modo a alcançar o mínimo de 12 anos de estudo no último ano, para as populações do campo, da região de menor escolaridade no país, e dos 25\% mais pobres, e igualar a escolaridade média entre negros e não negros declarados do IBGE (FNE, 2013, p. 62).

Uma média mínima de 12 anos de estudo para população entre 18 e 29 anos implica em mudanças bastante profundas no padrão atual do sistema, que mais reproduz e produz as desigualdades do que atua para a igualdade. A meta propõe a desejada superação, na educação, de clivagens de classe social, regionais, rural/ urbano e étnico-racial. Por uma via coerente, de buscar um mínimo de 12 anos de estudo para tais minorias.

Em relação à população negra, propõe igualar a média, com implicações distintas para as etapas da educação básica e educação superior. Para atingir tal meta é necessário aumento de cobertura, acesso e permanência na educação infantil numa ponta e na educação superior e pós-graduação na outra. No caso da desigualdade entre brancos e negros, o foco teria que ser especialmente pós-graduação, graduação e ensino médio, pois à medida que se avança nas etapas observa-se a ampliação do fosso entre tais grupos de cor/etnia. De acordo com dados do censo de 2010, analisados por Rosemberg (2013), na conclusão do ensino fundamental a população negra tinha uma defasagem de 29,6\% em comparação com a não negra; na conclusão do ensino médio esta defasagem era de 51,3\%; no ensino superior de 294,3\%; na conclusão da pós- 
graduação de 450,0\%. Além disso, a defasagem em média de anos de estudo no ensino fundamental, se não é tão ampla quanto na etapa posterior, é persistente e profundamente arraigada, conforme análise de Jaccoud e Beghin (2002) com uma diferença que se manteve durante todo o século XX. Então, chegar, ao final de 10 anos, a um regime de igualdade entre negros/as e brancos/as de 18/29 anos é meta ousada e necessária, que envolve uma complexidade de ações para ser realizada. A intersetorialidade proposta no item (classe, região, urbano/rural, raça/cor) é parte relevante no processo, mas não a única e medidas específicas de promoção de igualdade étnico-racial precisam ser ampliadas para se cumprir a importante meta.

No eixo V (Gestão Democrática, Participação Popular e Controle Social) verificamos um único item voltado para a diversidade, propondo a ampliação das taxas "de permanência e conclusão de estudantes do campo, negros, indígenas, povos das florestas, povos das águas, quilombolas, das comunidades tradicionais, das pessoas com deficiência, transtornos globais de desenvolvimento e altas habilidades ou superdotação" (FNE, 2013, p 76/77). Embora só se constate este, a questão da permanência e da conclusão é de alta relevância para garantir a igualdade, pois não basta garantir o acesso aos grupos socialmente excluídos, é necessário muitas ações internas nas instituições que Ihes garantam o sucesso escolar.

No eixo VI (Valorização dos Profissionais da Educação: formação, remuneração, carreira e condições de trabalho), observa-se uma amplitude maior de propostas que se articula com o que denominamos de agenda da diversidade, especialmente com propostas de produção de material didático e formação de professores, tanto inicial quanto continuada, nos temas gênero, diversidade e orientação sexual; promoção da saúde e dos direitos sociais e reprodutivos de jovens e adolescentes; diversidade cultural-religiosa; educação do campo; educação quilombola; educação escolar indígena; educação dos povos da floresta; dos povos das águas; das relações étnico-raciais; dos povos ciganos, para a educação especial, populações tradicionais e demais segmentos.

Aqui temos dois temas sobre os quais o restante do documento pouco trata e que tomam parte nas proposições de formação de professores, a diversidade religiosa e a escolaridade para povos ciganos. Ambos são de grande complexidade. As tensões sobre o ensino religioso no Brasil são permanentes e a afirmação do estado laico contrasta, na própria constituição, com a definição de oferta "facultativa" de ensino religioso na escola pública. Nos diversos estados existem diferentes orientações dos conselhos estaduais e municipais de educação quanto a oferta do ensino religioso, por vezes com orientação como campo da ciência, o estudo do fenômeno religioso, por outros por proposições confessionais (admitidas pela legislação). Nos anos recentes, tem sido denunciado o aumento das formas de discriminação e violência produzidas especialmente por movimentos cristãos fundamentalistas contra as religiões de matriz africana. Embora seja um tema abordado somente nesta parte, é assunto relevante e poderia compor outras metas para além da formação de professores e produção de material didático. Já a educação dos povos ciganos é outro tema complexo e quase esquecido. O país tem poucos dados sobre estes povos e sua escolaridade e demandas educacionais. Além disso, a própria definição de cigano é palco de disputas o que torna mais difícil a organização de informações e consequentemente a produção de políticas públicas em educação que os beneficiem. Apesar de pequena presença, é louvável que apareçam essas preocupações quando se trata da formação de professores, ao mesmo tempo que preocupa sua pouca inserção em outras metas da II Conae.

No eixo VII (Financiamento da Educação: gestão, transparência e controle social dos recursos), as duas primeiras metas focam no regime de colaboração e indicam o combate à desigualdades regionais, propondo priorizar "os entes federados com baixos índices de desenvolvimento socioeconômico e educacional, tendo como critérios indicadores o IDH, altas taxas de pobreza, índices de fragilidade educacional na oferta de EJA, entre outros" (FNE, 2013, p. 95). Tais critérios, em sendo aprovados e executados, possivelmente teriam impacto sobre as desigualdades de classe e de raça/cor. A meta 1 do eixo II propõe a disponibilidade de orçamento para as ações sobre educação e diversidade, o que talvez pudesse ter sido articulada com uma das metas deste eixo de financiamento. Uma meta propõe o transporte gratuito para a educação do campo e outra foca 
os orçamentos das instituições públicas de ensino superior, indicando a necessidade de "políticas de acesso e permanência de estudantes negros, indígenas, quilombolas, povos e comunidades tradicionais, entre outros, tanto na graduação quanto na pós-graduação" (FNE, 2013, p. 103).

\section{As relações raciais e as proposições para o eixo Educação e Diversidade na Conae-PR}

O Fórum Estadual de Educação (FEE) do Paraná apresentou as emendas em dois blocos, bloco I e bloco III. Segundo o regulamento da Conae, o bloco I contem as emendas que além de aprovadas em mais de $20 \%$ das conferências municipais tiveram indicação de aprovação pelo FEE. O bloco II teria as emendas aprovadas na mesma proporção, mas que o FEE indicaria sua reprovação, no entanto o mesmo FEE se absteve de montar um bloco com emendas que indicasse reprovação mesmo tendo sido aprovadas em 20\% das conferências e esse bloco não constou no caderno de emendas. No bloco III, por sua vez, foram colocadas as emendas passíveis de destaque por não atingirem um total de $20 \%$ em todas as conferências municipais, tendo sido feita uma sistematização que aglutinou emendas com a mesma redação e excluiu aquelas que se referiam a realidades locais de municípios ou regiões do estado.

No bloco I foram listadas as emendas que tiveram mais de $20 \%$ de aprovação nas diversas conferências municipais ocorridas no estado, correspondendo a aprovação em pelo menos 44 conferências municipais entre as realizadas no estado do Paraná. Os eixos I e IV não houve nenhuma emenda nesta situação, os eixos III e V tiveram uma emenda cada e o eixo VII teve duas emendas.

O eixo II, por sua vez, teve 23 emendas no bloco I, ou seja, teve quase 6 vezes mais que todos os demais eixos juntos. Essas emendas denotam um grau de organização e mobilização alto, indicando a participação e articulação dos movimentos sociais relacionados com a pauta da diversidade nas diversas conferências em âmbito municipal. Das 23 emendas aprovadas em 20\% das conferências para o eixo II, sete se relacionam com a igualdade étnico-racial, e nenhuma delas alterava de forma significativa as proposições do documentoreferência, sendo somente ajustes de linguagem (por exemplo, substituição de "negro" por "população negra"), portanto nem limitavam nem ampliavam as proposições vindas do FNE. Das 23 emendas, a maioria era aditiva, havia outras substitutivas e não houve supressivas, ou seja, foram propostas de adequações de texto e muitas vezes adição de termos relacionados com minorias específicas. Por exemplo, em uma meta que tratava de políticas afirmativas para grupos já citados no texto-referência (negros, indígenas, quilombolas, povos do campo, povos das águas, povos das florestas, comunidades tradicionais, pessoas com deficiência, gays, lésbicas, bissexuais, travestis e transexuais), foi proposto o acréscimo de "povos ciganos". A sua inclusão denota que suas demandas estão chegando nos espaços institucionalizados, provavelmente indicando maior organização desse grupo o que lhe garantiu a referência no texto, em conferências diversas, de modo a figurar no bloco I.

No bloco III, mesmo após a sistematização com aglutinação de repetições e exclusão de emendas dirigidas a realidades municipais, o número de emendas continuou alto e foram apresentadas somente para o eixo II (Educação e diversidade) um total de 838 emendas. Vários parágrafos e metas tiveram um número grande de emendas aprovadas em distintas conferências, sendo em muitos casos antagônicas ou contraditórias. Nossa análise busca justamente esses elementos de antagonismo, considerando-os como expressão de diferentes atores sociais que participaram das conferências. Ou seja, o fato de determinada meta ter sido amplamente debatida e ter tido emendas diversas, que se contradizem, aprovadas em diferentes municípios expressa compreensões distintas sobre a "agenda da diversidade".

A reflexão aqui recai especialmente sobre os parágrafos e metas que se relacionam com as proposições de igualdade étnico-racial, especialmente as voltadas para a população negra e para a população cigana (visto que a temática da educação indígena está contemplada em outro capítulo do livro). O intuito então é analisar as diversas formas de interpretação da temática étnico-racial expressas pelas emendas ao documento- 
referência da II Conae aprovadas em diferentes municípios do estado do Paraná. No entanto, uma análise geral das emendas sugere que as vozes dissonantes foram relativamente minoritárias no que se refere às proposições do eixo II, pois as emendas que mantêm ou ampliam o texto foram maioria absoluta em relação às que restringem as propostas.

A parte inicial do texto do eixo, que apresenta a temática, define diversidade e os grupos minoritários a que devem se dirigir as políticas, foi totalmente mantida ou ampliada. O parágrafo inicial do eixo é o que apresenta uma redação bastante contundente e que citamos anteriormente, afirmando que o tema título do eixo "constitui o eixo central da educação e objeto da política educacional" (FNE, 2013, p. 28). Este parágrafo não sofreu nenhuma emenda em qualquer conferência, ou seja, foi aprovado em todas e chegou à conferência estadual como pré-aprovado, visto que não podia nem ser destacado. De 40 das 54 emendas que tinham caráter aditivo, grande parte delas propunha detalhamento sobre grupos minoritários a serem contemplados. Foram apresentadas as seguintes adições: síndromes (TGD), transtornos globais do desenvolvimento, altas habilidades e superdotação; ciganos (em três distintos parágrafos); bifobia (além de lesbofobia); moradores em situação de rua; comunidade surda, comunidade judaica; direitos linguísticos dos surdos.

Além disso, figuram também proposta de acréscimos de grupos já citados no texto em outros parágrafos tais como: escolas de educação básica na modalidade educação especial; indígenas; quilombolas; população negra; pessoas com deficiências. Ainda, foi demandada a explicitação no texto de instrumentos de políticas específicas: Política Nacional para a População de Rua; Lei Maria da Penha; Educação escolar de povos ciganos; Diretrizes Curriculares para a EJA; Diretrizes Operacionais para a EJA; Política Nacional para a Escola de Educação Especial; decreto n. 4.887/03 que regulariza os territórios tradicionais das comunidades remanescentes de quilombos e a convenção 169 da Organização Internacional do Trabalho.

No que se refere aos povos ciganos, vimos que já havia sido feito menção em ponto específico do texto, mas aqui temos a proposição de sua inclusão em três diferentes parágrafos da introdução do eixo. Tais ocorrências sugerem que o reconhecimento desse grupo como minoria racial e que tem demandas específicas de políticas educacionais tem aumentado dentre os atores sociais envolvidos com a "agenda da diversidade". Além disso, encontra-se nas proposições o termo "educação escolar de povos ciganos", que nas políticas educacionais e por consequências nos sistemas estaduais e municipais de ensino é uma discussão ainda incipiente, ou seja, as proposições e mesmo a discussão durante a II Conae pode operar de forma que o tema ganhe legitimidade e possa ser ampliada a reflexão sobre o mesmo desencadeando políticas públicas antes mesmo da realização da Conferência Nacional, dado seu atraso.

No que se refere aos povos quilombolas, o parágrafo do documento-referência afirma:

Na educação, as ações afirmativas dizem respeito à garantia do acesso, da permanência e do direito à aprendizagem nos diferentes níveis, etapas e modalidades da educação aos grupos historicamente excluídos. Isto requer o pleno reconhecimento do direito à diferença e o posicionamento radical na luta pela superação das desigualdades socioeconômicas, raciais, de gênero, orientação sexual, regionais, de acesso à terra, moradia e oriunda da condição de deficiência, para o exercício dos direitos humanos (FNE, 2013, p. 29).

A proposta aprovada em uma das conferências municipais foi de acréscimo após o termo "de acesso à terra" de uma frase longa: "garantido a continuidade e a vigência do decreto n. 4.887/03 que regulariza os territórios tradicionais das comunidades remanescentes de quilombos e a convenção 169 da OIT”. A proposição articula-se pouco com a redação do parágrafo em tela. Indicando certa ansiedade dos participantes no que se refere ao tema que é central para os povos do campo e quilombolas e, mesmo como pouca coerência com o texto original, bastou a citação do tema de acesso à terra para acionar a necessidade de afirmar legislações específicas sobre a terra ou mais ampla, como é ocaso da referida convenção da OIT. Também revela que as mesmas não têm sido cumpridas, por isso a demanda à sua efetivação continua. 
Um outro tema que teve ocorrência de proposição de acréscimo relaciona-se com o parágrafo que afirma que: A concepção de direitos humanos, numa perspectiva emancipatória, se contrapõe à compreensão abstrata de humanidade ainda presente em muitos discursos, políticas e práticas de educação meramente regulatórios, que mantêm suposta neutralidade frente à luta pela inclusão social. Essa compreensão traduz a prevalência do modelo de humanidade, que nega a diversidade e reforça um determinado padrão de humano: branco, masculino, de classe média, adulto, heterossexual, ocidental e sem deficiência. Nessa concepção homogeneizante e hegemônica de direitos humanos, a diversidade é colocada como um problema e não como um dos principais eixos da experiência humana (FNE, 2013, p. 29).

Foi aprovado em uma conferência o acréscimo de "cristão" após "ocidental", marcando que a religiosidade hegemônica também opera de forma opressora contra as minorias religiosas. Em outro parágrafo, o tema entrou pela proposição de acréscimo da palavra "laicidade" relacionada com a diversidade, identidade, igualdade e direitos humanos. Apontamos que, mesmo de forma bastante pontual, as proposições do eixo II foram no sentido da crítica ao centralismo cristão e de afirmação da laicidade como princípio da educação brasileira.

As metas, em geral, receberam um número de emendas bem mais significativo que a introdução e é aqui que vamos encontrar com mais nitidez as múltiplas vozes, as quebras, injunções, contradições. A primeira meta do eixo II foi intensamente debatida. Ela afirma que é necessário assegurar recursos para a implementação das políticas da diversidade e inclusão e recebeu 31 emendas. Em dois municípios foi aprovada sua supressão. Isso revela um alto grau de tensão e contradições em relação ao tema, visto o que apontamos, isto é, a proposição no documento-referência da diversidade como eixo central da educação, não foi questionada em nenhuma conferência municipal. Ou seja, pode-se afirmar a diversidade como importante, mas definir recursos para a sua operacionalização já é muito menos consensual.

Consideramos que as proposições de supressão da meta, portanto, são significativas das posições conflitantes entre os participantes das conferências municipais. No entanto, o conjunto geral das emendas buscou o aprofundamento da temática. Por exemplo, a redação da meta inicia com o verbo no infinitivo "assegurar" e nove emendas propuseram acréscimos (doze no total, visto que três emendas foram aprovadas em dois distintos municípios), propondo a redação da meta como "assegurar em lei"; "assegurar efetivamente"; "assegurar e acelerar", "assegurar e prover"; "assegurar e manter", "assegurar e prover", "assegurar e viabilizar", "assegurar por meio de programas específicos", "assegurar entre os entes federados". Ou seja, as proposições de dirigir recursos e as diversas formas de reforçar o verbo "assegurar" apontam para uma hegemonia, nas conferências, das proposições orientadas pelos atores sociais que defendem a diversidade.

Na segunda proposição do eixo II temos uma redação que busca muito articular áreas da diversidade, com um texto longo que cita diversas legislações específicas sobre ensino de história e cultura afro-brasileira e indígena, educação escolar indígena, educação do campo, educação especial, educação em direitos humanos, educação ambiental, educação para jovens e adultos em privação de liberdade. As diversas emendas sobre este parágrafo 134 tem um sentido de agregar outros grupos e de dar densidade às propostas. No que se refere às questões étnico-raciais esta proposta opera no sentido de aprofundar o estabelecimento de políticas curriculares em curso. A despeito de termos normativas diversas que definiram legalmente que a educação deva constituir um ensino em que os conhecimentos dos diversos grupos sociais que compõem a sociedade brasileira sejam reconhecidos no processo educacional, as instituições escolares ainda se debatem entre a tradição curricular eurocêntrica e perspectivas multiculturais.

Em maior frequência, as emendas no eixo II tenderam a agregar ou identificar minorias não contempladas no texto original em determinadas metas; aprofundar as propostas e ajustes de redação. Em número menor figuraram a retirada de proposta ou de minorias das metas. A análise do documento e do material recebido na Conferência Estadual do Paraná apontam uma participação articulada e coesa dos movimentos sociais envolvidos com a "agenda da diversidade" no sentido de garantir políticas educacionais não hierarquizantes, reconhecendo as diferenças e combatendo as desigualdades. 


\section{Síntese conclusiva}

A análise do tratamento da temática da diversidade no documento base da ll Conae revela um aprofundamento da agenda no decorrer do processo, com especificação crescente dos movimentos sociais e minorias a serem atendidos com políticas focais.

Além disso, a pauta ampla da diversidade contou com proposições diversas e difundidas em todos os eixos, especialmente nas metas. Novos movimentos sociais entram nas metas (quilombolas, povos da floresta, povos das águas, povos ciganos). Sobre a população cigana, aparece a proposta de formação de professores o que pode ser interpretado como um avanço, mas, ao mesmo tempo, pouco significativa porque no restante do texto mantem pouca inserção.

A análise das diferentes proposições de emendas para as metas do eixo II revela um debate bastante intenso e, como não deveria deixar de ser, posições antagônicas. Ao passo que identificamos movimentos de retirada de propostas de promoção de igualdade étnico-racial no texto, a tendência geral foi de reafirmação e aumento de garantia dos direitos das minorias, inclusive agregando novos grupos às metas específicas, ou aprofundando as propostas das metas.

A interpretação é que os movimentos sociais em geral e os movimentos negros em específico passaram a atuar de forma a organizar acordos com os demais movimentos, o que fica patente pela análise dos documentos e pela sua participação nas conferências. Ao não hierarquizarem as diferenças, os movimentos sociais atuaram para o reconhecimento da voz e da demanda dos outros, ao mesmo tempo em que tiveram maior sucesso na aprovação de suas pautas e proposições.

\section{Referências}

FÓRUM NACIONAL DE EDUCAÇÃO. Documento-Referência/CONAE, 2014. PNE na Articulação do Sistema Nacional de Educação: Participação Popular, Cooperação Federativa e regime de colaboração, 2013.

JACCOUD, L. B.; BEGHIN, N. Desigualdades raciais no Brasil: um balanço da intervenção governamental. Brasília : Ipea, 2002.

LAPLANE. A. L. F.; PRIETO, R. G. Inclusão, Diversidade e Igualdade na CONAE 2010: perspectivas para o novo Plano Nacional de Educação. Educação e Sociedade, Campinas, v. 31, n. 112, p. 919-938, jul.-set. 2010. Disponível em <http://www.cedes.unicamp.br>. Acesso em 17 Jun. 2014

PIERUCCI, A. F. As ciladas da diferença. São Paulo: Ed.34, 1999.

PIOVESAN, F. Ações Afirmativas da Perspectiva dos Direitos Humanos. Cadernos de Pesquisa, v. 35, n. 124, p. 43-55, jan./abr. 2005.

RODRIGUES, T. C.; ABRAMOWICZ, A. Diversidade e as políticas públicas comparadas de educação. Revista Contrapontos, Itajaí, SC., v. 11, n. 3, p. 244-254, out. 2011. Disponível em: <http://www6.univali.br/seer/index. php/rc/article/view/2936/2026>. Acesso em: 17 Jun. 2014.

ROSEMBERG, F. Relações raciais e desigualdades educacionais no Brasil Contemporâneo. Palestra de abertura da Semana de Ensino Pesquisa e Extensão do Setor de Educação (SEPE), Universidade Federal do Paraná, 2013. 


\title{
Políticas Curriculares para o Ensino Médio e para a Educação Profissional: propostas, controvérsias e disputas em face das proposições do Documento Referência da Conae 2014
}

\author{
Curricular Policies to High School and Professional Education: \\ proposals, controversies and discussions in the face of Conae \\ 2014 Reference Document
}

Políticas Curriculares para la Escuela Secundaria y para la Formación Profesional: propuestas, controversias y conflictos frente a las proposiciones del Documento de Referencia de la Conae 2014

\section{Márcio Luiz Bernardim Monica Ribeiro da Silva²}

\section{Resumo}

O texto traz uma análise das proposições de políticas para o Ensino Médio e para a Educação Profissional Técnica de Nível Médio, com ênfase para a formulação de diretrizes curriculares. Toma por referência as proposições presentes no contexto da discussão da Lei de Diretrizes e Bases da Educação em torno da ideia de formação tecnológica, formação politécnica ou formação integrada, assumidas aqui como correlatas. Analisa, além das proposições presentes na LDB de 1996, os textos oficiais que tratam da matéria, notadamente os exarados pelo Conselho Nacional de Educação, em dois momentos distintos. O primeiro, quando da proposição das Diretrizes Curriculares de 1998 e 1999 e o segundo, quando da revisão e reformulação dessas Diretrizes, entre os anos de 2011 e 2012. O estudo mostra um embate de concepções e uma disputa por projetos societários e educativos que marcam a formulação dessas políticas curriculares. Tais embates e disputas são analisados à luz do Documento Referência da Conae 2014.

Palavras Chaves: Políticas Curriculares; Ensino Médio; Educação Profissional Técnica de Nível Médio; Diretrizes Curriculares.

\footnotetext{
1 Professor Adjunto da Universidade Estadual do Centro Oeste (UNICENTRO). Doutor em Educação pela Universidade Federal do Paraná (UFPR). E-mail: marcio. bernardim@gmail.com
}

2 Professora Associada da Universidade Federal do Paraná (UFPR). Doutora em Educação pela Pontifícia Universidade Católica de São Paulo (PUC-SP). E-mail: monicars@ufpr.br 


\begin{abstract}
The text brings an analysis of the policy propositions to High School and to Technic Professional High School Education, focusing on the curricular guidelines formulation. It takes as reference the present formulations found within the context of the Education Guidelines and Basis Law about the idea of technological, polytechnic or integrated formation, which are assumed here as correlated. It analyses, besides the propositions that are in the 1996 LDB, the official texts that deal with the subject, notedly the registered by the National Council of Education ones, in two distinct moments. The first one, by the time of the proposition of the Curricular Guidelines in 1998 and 1999; and the second one, by the time of the reformulation of the same guidelines, between 2011 and 2012. The study shows an opposition of conceptions and a dispute for societary and educative projects that determine the elaboration of those curricular policies and that are present in the Conae 2014 Reference Document.

Key words: Curricular Policies; High School; Technic Professional High School Education; Curricular Guidelines.
\end{abstract}

\title{
Resumen
}

El texto ofrece un análisis de las propuestas de políticas de Educación Secundaria y Formación Profesional de Técnica de nivel secundário, con énfasis en el desarrollo de los lineamientos curriculares. Toma por proposiciones las referencia presentes en el contexto de la discusión de la Ley de Directrices y Bases de la Educación sobre la idea de formación tecnológica, formación politécnica o entrenamiento integrado, asumidas aquí como relacionada. El artículo analisia, además de las propuestas actuales en 1996 LDB, los textos oficiales que se ocupan de la materia, en particular los formalizados por el Consejo Nacional de Educación, en dos momentos diferentes. El primero, cuando de la proposición de las Directrices Curriculares de 1998 y 1999 y el segundo, en la revisión y reformulación de las presentes Directrices, entre los años 2011 y 2012. El estudio muestra un choque de ideas y un concurso de proyectos de sociedad y educativos que marcan la formulación de estas políticas curriculares. Tales conflictos y disputas son analizadas frente al Documento de Referencia de la Conae 2014.

Palabras-clave: Políticas curriculares; Enseñanza secundária; Educación técnica de nivel secundário; Directrizes curriculares.

\section{Introdução}

Atualmente pouco mais de $50 \%$ dos jovens cursam o Ensino Médio na faixa etária adequada, além do que cerca de $35 \%$ dos matriculados estudam à noite e muitas vezes em precárias condições. De acordo com o Censo Demográfico de 2011, o Brasil possui 10,3 milhões de jovens entre 15 e 17 anos, dos quais apenas 5,4 milhões encontram-se matriculados na última etapa da educação básica. Aproximadamente 3 milhões e 300 mil encontravam-se, em 2012, matriculados no Ensino Fundamental e pouco mais de 1 milhão de jovens nessa faixa etária estavam fora da escola, em que pese pertencerem à faixa etária de escolaridade obrigatória. A matrícula total na última etapa da Educação Básica é de 8.312.815, conforme mostra o censo escolar de 2013 (INEP, 2014), indicando que um número bastante expressivo de estudantes desta etapa possui mais de 17 anos.

Com relação à Educação Profissional Técnica de Nível Médio (EPTNM), de acordo com a Sinopse Estatística da Educação (INEP, 2013), o Brasil tem 1,4 milhão de matriculados, dos quais 338 mil na oferta Integrada, 310 mil na forma Concomitante e 793 mil na oferta Subsequente. Enquanto a oferta Integrada é atendida basicamente pelas redes públicas federal, estaduais e municipais, perfazendo $92 \%$ do total das matrículas, as ofertas Concomitante e Subsequente são atendidas majoritariamente pela rede privada, com 65\% e 58\%, respectivamente. 
Esses dados suscitam questionamentos sobre como vem se dando o diálogo entre necessidades da sociedade, em particular da(s) juventude(s) e as políticas curriculares para o Ensino Médio e para a Educação Profissional Técnica de Nível Médio. Um aspecto que de certo modo se mantém presente nos últimos quase 30 anos desde os debates em torno da atual Lei de Diretrizes e Bases da Educação Nacional (LDB), Lei Federal 9.394/96, é a relação entre escola, juventude e trabalho, observando-se distintas compreensões acerca das relações entre trabalho e educação. Tomando-se por referência o contexto de redemocratização do país, que marcou as discussões sobre a LDB no período compreendido entre 1986 e 1996, identifica-se como uma das propostas presentes a concepção de formação integrada, formação tecnológica e/ou formação politécnica, frequentemente empregadas como correlatas e que, embora timidamente, encontra-se incorporada no texto da LDB.

Este texto busca mostrar aproximações e distanciamentos em relação à ideia de formação politécnica/ tecnológica/integrada em três momentos da formulação de políticas para o Ensino Médio no Brasil: no contexto da elaboração da LDB; nas proposições das Diretrizes Curriculares Nacionais para o Ensino Médio de 1998 (Parecer CNE/CEB 15/98) e para a Educação Profissional de 1999 (Parecer CNE/CEB 16/99); e nas atuais Diretrizes Curriculares Nacionais para o Ensino Médio (Parecer CNE/CEB 05/2011 e Resolução CNE/CEB 02/2012) e para a Educação Profissional Técnica de Nível Médio (Parecer CNE/CEB 11/2012 e Resolução CNE/ CEB 06/2012). A finalidade dessa discussão se ancora, principalmente, na necessidade de aprofundamento e ampliação do debate considerando as proposições presentes no Documento Referência para a realização da Conferência Nacional de Educação - Conae 2014 e as possibilidades dela decorrentes, de orientar e subsidiar a definição e a análise de políticas educacionais para esta etapa e modalidade de oferta da educação básica.

\section{Proposições do Documento Referência da Conae 2014 para o Ensino Médio e para a Educação Profissional Técnica de Nível Médio}

As concepções e propostas para o Ensino Médio e para a Educação Profissional estão explicitadas principalmente (mas não exclusivamente) no Eixo III - Educação, trabalho, desenvolvimento sustentável, saúde e meio ambiente do Documento Referência da Conae 2014. Para a presente análise, considerou-se a versão que inclui as proposições advindas das conferências municipais e estaduais constantes do texto que serviu de base para a Conferência Nacional de Educação realizada em Brasília-DF entre os dias 19 e 22 de novembro de 2014.

O Documento referência da Conae 2014 considera a educação como prática social cada vez mais ampla e presente na sociedade atual. A compreensão e formulação de propostas para a educação passa, necessariamente, conforme o Documento da Conae 2014, por considerar as transformações econômicas e políticas ocorridas na esfera mundial e local, em especial as relativas à reestruturação produtiva, à mundialização do capital e às novas formas de regulação econômica e social a elas relacionadas ${ }^{3}$ (BRASIL, 2014, p. 46).

Considerando as mudanças na configuração social do país nas últimas décadas, com ênfase para os processos que ampliaram as dificuldades de inserção dos jovens no mundo do trabalho, o agravamento do desemprego juvenil e a não inclusão de expressiva parcela da juventude brasileira no sistema educacional, o Documento Referência da Conae 2014 confere destaque ao desafio educacional associado ao desenvolvimento científico e tecnológico. Desse modo, educação, ciência, tecnologia e sustentabilidade tornam-se "elementos fundamentais nos processos de desenvolvimento econômico e social" do país (BRASIL, 2014, p. 57). Tais elementos adquirem centralidade quando se trata da definição de políticas para o Ensino Médio e para a Educação Profissional.

\footnotetext{
3 A constituição de um novo padrão de acumulação e regulação "sustenta-se em dois alicerces fundamentais que demarcam uma nova base técnica do trabalho e caracterizam a reestruturação produtiva: assenta-se na adoção de novas tecnologias que se utilizam da microeletrônica no processo de produção e de circulação de mercadorias e serviços; e, na adoção de novas formas de organização e gestão da produção inspirados que demandam participação ativa por parte do trabalhador no processo de trabalho. 0 que tem sido retratado com frequência como um movimento de reestruturação produtiva mostra-se como uma reestruturação da sociedade e que conduz a mudanças nos processos de formação para além das anunciadas como adequação ao que é requerido pelo mercado de trabalho".
} 
Com vistas a demonstrar tal centralidade, e dada a natureza e escopo deste artigo, confere-se destaque a duas formulações, destacadas por compreenderam de modo geral e substantivo, as concepções e propostas do Documento da Conae. A primeira diz respeito ao Ensino Médio de educação geral. A segunda, à Educação Profissional Técnica de Nível Médio.

247 - 8.18. Reestruturar o Ensino Médio, incentivando práticas pedagógicas com abordagens interdisciplinares, estruturadas pela relação entre teoria e prática, por meio de currículos escolares com conteúdos obrigatórios e eletivos, em dimensões como ciência, arte, trabalho, linguagens, tecnologia, cultura, meio ambiente e esporte, garantindo a aquisição de equipamentos e laboratórios, a produção de material didático específico, o reconhecimento da diversidade linguística, a formação continuada de professores e a articulação com instituições acadêmicas, esportivas e culturais (BRASIL, 2014, p. 57).

E

239 - 8.10. Garantir expandir a Educação Profissional pública de qualidade, em diferentes modalidades e níveis, na perspectiva do trabalho como princípio educativo, com financiamento público permanente, que atenda às demandas produtivas e sociais locais, regionais e nacionais, em consonância com a sustentabilidade socioambiental, com a gestão territorial e com a inclusão social, as diversidades étnico-raciais de modo a dar suporte aos arranjos produtivos locais e regionais, contribuindo com o desenvolvimento econômico-social (BRASIL, 2014, p. 56).

A seguir, faz-se um percurso analítico das proposições oficiais para a organização pedagógico-curricular para o Ensino Médio e para a Educação Profissional nas duas últimas décadas com vistas a identificar elementos que possam ter servido de referência para as formulações acima destacadas ou que caracterizem embates, controvérsias ou disputas em torno da definição dessas políticas.

\section{A LDB 9.394/96, as proposições para o Ensino Médio e a ideia de formação politécnica}

A LDB consagrou o Ensino Médio como educação básica. Este é um aspecto realmente positivo no sentido da definição de uma identidade para essa etapa educacional, em que pese não ter sido assegurada a necessária condição de obrigatoriedade. A lei define que a educação escolar deve estar vinculada ao mundo do trabalho e à prática social e que compete à educação básica possibilitar uma formação comum com vistas ao exercício da cidadania e ao fornecimento dos meios para progredir no trabalho e em estudos posteriores (art. 22).

O Ensino Médio com duração mínima de três anos possui, conforme a LDB, as finalidades de consolidação e aprofundamento dos conhecimentos adquiridos no ensino fundamental, possibilitando o prosseguimento de estudos; de preparação básica para o trabalho; de formação ética, de desenvolvimento da autonomia intelectual e do pensamento crítico do educando; de compreensão dos fundamentos científico-tecnológicos dos processos produtivos (art. 35).

Tendo em vista alcançar essas finalidades, a Lei de Diretrizes e Bases propõe que o currículo e a organização pedagógica do Ensino Médio confiram especial ênfase à educação tecnológica básica; à compreensão do significado da ciência, das letras e das artes; ao processo histórico de transformação da sociedade e da cultura; à língua portuguesa como instrumento de comunicação, acesso ao conhecimento e exercício da cidadania.

A concepção de Ensino Médio estabelecida na LDB traz, ainda que de forma pouco precisa, a incorporação da ideia de uma educação tecnológica, que deveria ser capaz de relacionar teoria e prática, mundo da ciência e mundo do trabalho, enfim, algo que se assemelha a uma formação politécnica, proposição que vinha sendo alvo das discussões entre os educadores nos anos que antecederam a elaboração da LDB, bem como nos momentos em que, a pretexto dela, realizaram-se inúmeros debates nos quais a questão da definição da identidade dessa etapa da educação básica era preocupação recorrente. Distanciando-se, no entanto, dessa compreensão ampliada, o texto final da LDB toma o trabalho em um sentido mais restrito, por vezes dimensionado como ocupação ou emprego.

No contexto de elaboração da LDB, as críticas a um Ensino Médio elitista e excludente apontavam para a necessidade de se tomar o mundo do trabalho como referência para a definição da identidade dessa etapa 
da educação básica. O conceito chave em torno do qual se articulava essa intenção era o de "politecnia", entendido, naquele contexto, como a formação humana assentada na tríade que compreende a educação intelectual, a educação do corpo e a educação tecnológica (MACHADO, 1989, p. 124).

O sentido de educação tecnológica proposta na LDB, vale ressaltar, deriva dos debates em torno da formação politécnica e significa conduzir, tal qual explicitado no corpo da lei, à compreensão dos princípios e fundamentos científicos das técnicas criadas com o fim de satisfazer as necessidades humanas nos mais diferentes contextos, tempos e espaços em que essa produção se dá. Nessa direção, a proposição presente na LDB se aproxima da ideia de formação politécnica ou tecnológica, bem como encontra ressonância nas propostas acima destacadas do Documento Referência da Conae 2014.

\section{O pós-LDB 9.394/96: as diretrizes curriculares de 1998 e 1999, a centralidade da noção de competências e o distanciamento da ideia de formação politécnica}

Entre os anos de 1995 e 2000 foram produzidos vários documentos de política que, se divergem em sua natureza - ora assumem o caráter de proposta, ora têm uma função normativa - manifestam uma mesma intencionalidade, qual seja a de produzir mudança significativa na estrutura curricular do Ensino Médio. Os principais documentos oficiais que explicitam essa intenção são: os Parâmetros Curriculares Nacionais para o Ensino Médio (PCNEM), produzidos sob orientação do MEC pela sua Secretaria de Educação Média e Tecnológica (SEMTEC); as Diretrizes Curriculares Nacionais para o Ensino Médio (DCNEM), explicitadas no Parecer 15/98 e na Resolução 3/98 da Câmara de Educação Básica (CEB) do Conselho Nacional de Educação (CNE); e, ainda, as duas formas de avaliação, o Sistema Nacional de Avaliação da Educação Básica (SAEB) e o Exame Nacional do Ensino Médio (ENEM).

A política norteadora da reforma curricular esteve articulada ao pressuposto de uma propalada necessidade de articulação entre demandas da economia e educação escolar. Esse pressuposto se mostrou ora de forma explícita, ora subsumido no interior dos dispositivos legais que fundamentaram e normatizaram a reforma do Ensino Médio no momento imediatamente após a promulgação da LDB. No que diz respeito à reforma curricular, o pressuposto da necessidade de adequação da escola média às demandas da economia traduzia-se na necessidade de mudança do paradigma curricular. De modo recorrente as proposições das DCNEM (1998) e PCNEM afirmavam que a organização do currículo com base nos saberes disciplinares tradicionais não mais responderia às demandas da esfera produtiva, especialmente no que diz respeito à formação para o mundo do trabalho. Em substituição, foi proposta a organização curricular com base na definição de competências e habilidades.

A multiplicidade de origens e significados atribuídos ao termo competências entre os diferentes dispositivos normativos culminaram em um discurso fragmentado, mas nem por isso desarticulado. A lógica que o articula está dada pelas mudanças tecnológicas e organizacionais dos processos produtivos, conforme justificativa encontrada nos textos normativos e que, no campo da educação, conduziria à homogeneização dos requisitos de formação, marcados, especialmente, pelo atendimento a demandas advindas do mercado de trabalho.

Observa-se ainda, tanto nas proposições dos PCNEM e das DCNEM, quanto nos encaminhamentos do SAEB e do ENEM, que seus formuladores partiram do pressuposto de que o emprego da noção de competências fosse algo consensual, amplamente partilhado e de conhecimento, inclusive, por parte dos que teriam que lidar com essa referência sem terem, no entanto, se envolvido com o processo de definição dessas políticas, os professores. Essa pressuposição explica, por exemplo, a fluidez e as ambiguidades presentes na maneira com que é exposta a noção de competências nas poucas vezes em que se tenta defini-la, ou nas inúmeras vezes em que é prescrita como resultado desejado da organização pedagógica-curricular (SILVA, 2008; 2012).

Deve-se lembrar que o momento histórico de homologação das diretrizes para o Ensino Médio, seja na versão para educação geral (1998), seja na versão de Educação Profissional (1999), estava marcado pela 
abertura dos mercados nacionais e pelo incentivo ao comércio internacional como estratégias de enfrentamento ao baixo crescimento econômico verificado nos anos 1980 e início dos anos 1990. Também estavam na ordem do dia os efeitos das crises econômicas do México e da Ásia. No plano econômico interno, o Brasil havia finalmente controlado a inflação e estava prestes, no plano político, a reeleger o presidente Fernando Henrique Cardoso, que capitaneava a desregulamentação econômica, com privatização de estatais e flexibilização das relações de trabalho.

Essa orientação do governo resultaria em uma nova estratégia de incorporação dos trabalhadores ao mercado, conforme mostra Ferretti (2010, p. 97):

No que diz respeito ao trabalhador, essa incorporação tende, cada vez menos, a passar pelo crivo e orientação do coletivo e cada vez mais pelas competências individuais. Isso implica uma alteração fundamental nas relações contratuais entre capital e trabalho porque, por esse processo, o lado do capital se fortalece exponencialmente, na mesma medida em que 0 do trabalho se enfraquece. As disputas contratuais tendem a ser não mais entre dois coletivos, mas entre um coletivo muito forte, a empresa, e, de outro lado, os sujeitos individuais, contratados individualmente - como antes -, mas agora sem a mediação e a cobertura do sindicato.

Esses elementos ajudam a compreender por que o discurso do sistema produtivo, preocupado com a recuperação das "perdas" e ampliação dos lucros, e maquiado pela metalinguagem da eficiência e produtividade, foi incorporado nas políticas públicas, aí incluída a educacional, gerando um especial tensionamento durante a elaboração das diretrizes para o Ensino Médio e para a Educação Profissional.

Nesse contexto, portanto, as primeiras diretrizes defendiam o "prolongamento da escolaridade e a ampliação das oportunidades de continuar aprendendo" (BRASIL, MEC, DCNEM, 1998, p. 18) e a "vinculação entre educação e trabalho, na perspectiva da laboralidade [...] para se entender o conceito de competência como capacidade pessoal de articular os saberes [...] inerentes a situações concretas de trabalho" (BRASIL, MEC, DCNEP, 1999, p. 19).

Segundo Silva (2004, p. 9), "a centralidade da noção de competências, como eixo articulador da formação e da atuação profissional desloca, para o indivíduo, a responsabilidade de assegurar as condições de ingresso e permanência no emprego". Não por acaso, durante a década de 1990 os neologismos proliferaram no âmbito das relações de trabalho, sendo o termo "empregabilidade" o mais paradigmático deles. Sua defesa é coerente com o discurso de que as incongruências, as exclusões e a marginalização dos trabalhadores não são fruto do capitalismo, mas culpa deles próprios ou da escola, quando não se preparam para enfrentar os desafios da sociedade mercantilizada.

O modo como está retratada a relação entre mudanças tecnológicas, mudanças no conhecimento e necessidade de mudanças na educação escolar ilustra a maneira pela qual os propositores desses Parâmetros e Diretrizes recaíram em um determinismo econômico que circunscreve uma visão parcial e limitada do papel da escola. Nesse contexto, a escola fica restrita à formação para o mercado de trabalho e suas finalidades vinculadas à produção econômica, ainda que afirme uma pretensa formação para a cidadania, que também se confunde com os anseios de observância à lógica do mercado.

Os argumentos apresentados permitem afirmar que tais formulações se distanciam do debate que marcou as discussões sobre o Ensino Médio no contexto da elaboração da LDB, que girou, fortemente, em torno da ideia de formação politécnica e de educação tecnológica, na acepção já explicitada. Se distanciam, igualmente, das concepções presentes no Documento Referência da Conae 2014, sobretudo no que diz respeito à formação para o mundo do trabalho. Para este documento, a educação básica, mesmo aquela que se volta para a formação profissional, não deve perder de vista o horizonte da formação tecnológica, integral e integrada por meio das dimensões do trabalho, da ciência, da tecnologia e da cultura.

Os limites das proposições das Diretrizes Curriculares de 1998 e 1999, o novo cenário político brasileiro a partir do início dos anos 2000 e os debates em torno de um novo Plano Nacional de Educação (PNE) revigoraram as discussões em torno das políticas para a educação básica. Somente, porém, ao final da década, é que se 
coloca em pauta a necessidade de revisão das diretrizes exaradas pelo Conselho Nacional de Educação. Esse processo e o contexto em que ele transcorre são tratados na seção a seguir.

\section{As novas/atuais Diretrizes Curriculares Nacionais para o Ensino Médio e Educação Profissional: tensionamentos em torno da (re)aproximação da proposta de formação politécnica}

A Emenda Constitucional n 59/2009 (BRASIL, 2009) e os Planos Nacionais de Educação (BRASIL, 2001; 2014) sinalizam na direção da universalização do acesso à última etapa da educação básica, o que implica na ampliação do financiamento e na criação de possibilidades curriculares que propiciem a atribuição de novos sentidos ao currículo e à experiência vivida na escola pelos jovens (e adultos) que a frequentam, considerando a diversidade das culturas e identidades juvenis, as necessidades e expectativas de seus sujeitos, e as demandas da sociedade atual.

Na esteira da formulação de novos cenários para o Ensino Médio estão as novas Diretrizes Curriculares Nacionais para o Ensino Médio (Parecer CNE/CEB 05/2011 e Resolução CNE/CEB 02/2012) e as Diretrizes Curriculares Nacionais para a Educação Profissional (Parecer CNE/CEB 11/2012 e Resolução CNE/CEB 06/2012).

A retomada da Educação Profissional enquanto política teve início com os Decretos $n^{\circ} 2.208 / 1997$ e $n^{\circ}$ 5.154/2004 (BRASIL, 1997, 2004) e com os pareceres e resoluções do Conselho Nacional de Educação a eles relacionados, que trataram da organização e das diretrizes da Educação Profissional Técnica de Nível Médio (EPTNM). Em ambos os casos, ressentiram-se de melhor clareza na concepção e planejamento da Educação Profissional de modo que proporcionassem o abandono dos percursos formativos fragmentados, destituídos de significado mais amplo para a formação do trabalhador, ficando claro que tais alterações "se plasmaram para que esta esfera se ajustasse aos processos de desregulamentação, flexibilização e privatização" (FRIGOTTO, CIAVATTA e RAMOS, 2005, p. 13).

A crítica que se disseminou entre os educadores que reivindicavam um itinerário formativo único e integrado, onde não houvesse separação entre Educação Profissional e Ensino Médio, prevista no Decreto n².208/1997, é que sensibilizou o governo para a incorporação, pelo seu sucedâneo 5.154/2004, da possibilidade de oferta integrada.

Assim como os decretos citados, outros dispositivos legais afetaram o percurso recente da EPTNM no Brasil, focados na melhoria dos indicadores de escolarização e "profissionalização", refletindo o esforço para elevar a imagem externa e possibilitar maior participação brasileira no mercado globalizado e na divisão internacional do trabalho, sem romper, portanto, com a lógica de conformação da educação escolar às demandas do mercado de trabalho.

Apesar do tangenciamento da educação escolar aos interesses do sistema produtivo, não é demais esperar que as políticas de Educação Profissional contribuam, ao mesmo tempo, para a conclusão da educação básica e para a inserção laboral ou melhoria das condições de ocupação e renda dos trabalhadores, sem que isso impeça o seu acesso a um Ensino Médio de qualidade, ou que obstaculize o seu avanço ao ensino superior.

Nessa perspectiva, a análise dos contextos social, econômico e político em que as diretrizes foram concebidas ajuda a compreender os avanços e limites do Ensino Médio e da Educação Profissional nas últimas duas décadas.

Ao retomar a análise dos cenários em que se construíram as diretrizes, deve-se lembrar que depois de uma década desde as primeiras versões (1998/1999), e mais de sete anos da mudança de orientação política na condução do governo federal (2003), deflagrou-se a revisão desses documentos normativos, chegandose à homologação, em 2011, das DCNEM, mediante o Parecer 05/2011 e Resolução 02/2012, e das DCNEP, mediante o Parecer 11/2012 e Resolução 06/2012, todos emanados do CNE/CEB.

No interstício de treze anos entre as versões antigas e novas, os indicadores brasileiros mostram uma melhora em geral, tanto no aspecto econômico quanto social: mesmo em tempos de alternadas crises financeiras, o Produto Interno Bruto, ainda que baixo, apresenta resultados acima da média mundial; a inflação inspira 
preocupações, mas segue controlada; os juros chegaram aos níveis mais baixos registrados na história brasileira recente e, além disso, não houve necessidade de novos empréstimos internacionais para rolar a dívida externa. Tudo isso contribuiu para melhorar a imagem do Brasil perante os países ricos e os organismos internacionais, o que não significa uma transformação qualitativa radical, haja vista o aprofundamento do fosso entre ricos e pobres e a necessidade de políticas de renda mínima, como o Programa Bolsa-Família.

É esse, portanto, em síntese, o contexto no qual foram concebidas as políticas públicas recentes, dentre as quais aquelas que procuram intervir na realidade mediante a ampliação da escolaridade da população, ganhando destaque as preocupações com o Ensino Médio enquanto etapa escolar privilegiada de mediação da relação dos filhos da classe trabalhadora com o mundo do trabalho.

As novas Diretrizes Curriculares para o Ensino Médio têm como fundamento a formação integral do estudante, o trabalho como princípio educativo e a pesquisa como princípio pedagógico; a educação em direitos humanos; a sustentabilidade ambiental como meta universal; a indissociabilidade entre educação e prática social, considerando-se a historicidade dos conhecimentos e dos sujeitos do processo educativo, bem como entre teoria e prática no processo de ensino-aprendizagem; a integração de conhecimentos gerais e, quando for o caso, técnico-profissionais realizada na perspectiva da interdisciplinaridade e da contextualização; o reconhecimento e aceitação da diversidade e da realidade concreta dos sujeitos do processo educativo, das formas de produção, dos processos de trabalho e das culturas a eles subjacentes; a integração entre educação e as dimensões do trabalho, da ciência, da tecnologia e da cultura como base da proposta e do desenvolvimento curricular.

O Ensino Médio deverá considerar o trabalho, a ciência, a cultura e a tecnologia como dimensões da formação humana e eixo da organização curricular. O texto das DCN para o Ensino Médio assim compreende essas dimensões:

$\S 1^{0} 0$ trabalho é conceituado na sua perspectiva ontológica de transformação da natureza, como realização inerente ao ser humano e como mediação no processo de produção da sua existência;

$\S 2^{\circ}$ A ciência é conceituada como o conjunto de conhecimentos sistematizados, produzidos socialmente ao longo da história, na busca da compreensão e transformação da natureza e da sociedade.

$\S 3^{\circ}$ A tecnologia é conceituada como a transformação da ciência em força produtiva ou mediação do conhecimento científico e a produção, marcada, desde sua origem, pelas relações sociais que a levaram a ser produzida.

$\S 4^{\circ}$ A cultura é conceituada como o processo de produção de expressões materiais, símbolos, representações e significados que correspondem a valores éticos, políticos e estéticos que orientam as normas de conduta de uma sociedade (Brasil, Parecer CNE/CEB 05/2011).

Essas Diretrizes estabelecem ainda que a organização curricular do Ensino Médio possua uma base nacional comum e uma parte diversificada (art. $7^{\circ}$ ) e que as mesmas não se constituem em blocos distintos, mas em um todo integrado. O currículo deverá se organizar em quatro áreas do conhecimento: Linguagens, Matemática, Ciências da Natureza e Ciências Humanas.

A compreensão dos processos sociais a partir dos significados produzidos pela articulação entre trabalho e cultura, entre ciência e tecnologia, conforme estabelecido nas Diretrizes Curriculares Nacionais para o Ensino Médio (Parecer CNE/CEB 05/2011 e Resolução CNE/CEB 02/2012; MEC, 2011 e 2012) confere uma identidade para o Ensino Médio ao propor que esta última etapa da educação básica se oriente pela busca de uma formação humana integral. A ideia de formação integral e integrada converge com as formulações em torno do conceito de formação politécnica e tecnológica e tem sido referência quando se trata de propor políticas de currículo que visem a uma organização pedagógica menos fragmentada e hierarquizada. Tais proposições resgatam o debate que vinha sendo feito acerca da identidade do Ensino Médio no contexto das discussões da atual LDB e que, pelas correlações de força daquele período, acabou enfraquecida.

Quanto às Diretrizes Curriculares Nacionais para a Educação Profissional, o primeiro texto (BRASIL, MEC, DCNEP, 1999) fazia alusão ao artigo 40 da LDBEN, prescrevendo o desenvolvimento do ensino técnico "em 
articulação com o ensino regular, ou por diferentes estratégias de educação continuada". O relator entendia que articulação indicava mais que simplesmente complementaridade:

[...] implica em intercomplementaridade mantendo-se a identidade de ambos; propõe uma região comum, uma comunhão de finalidades, uma ação planejada e combinada entre o Ensino Médio e o ensino técnico. Nem separação, como foi a tradição da educação brasileira até os anos 70, nem conjugação redutora em cursos profissionalizantes, sucedâneos empobrecidos da educação geral, tal qual a propiciada pela Lei Federal n ${ }^{0}$ 5.692/71. Mas, na sua articulação com o Ensino Médio a educação técnica deve buscar como expressar, na sua especificidade, os valores estéticos, políticos e éticos que ambos comungam (BRASIL, MEC, DCNEP, 1999, p.14-15).

Além da "intercomplementaridade" não ter se resolvido com o tempo, verifica-se que as novas diretrizes (MEC, DCNEP, 2012, p. 58) mantiveram a Educação Profissional "articulada e subsequente ao Ensino Médio, podendo a primeira ser integrada ou concomitante a essa etapa da Educação Básica", conf. art. 3․ A previsão de Educação Profissional "não integrada" ao Ensino Médio, tanto na forma concomitante quanto na forma subsequente, não é mera questão curricular ou de organização do trabalho pedagógico escolar, permitindo inferir que ao manter percursos formativos fragmentados, divididos e não integrados, a escola reproduz e aprofunda a dualidade, marca histórica quando se trata do Ensino Médio.

A manutenção da não integração reflete o percurso inicial escolhido para a elaboração das novas DCNEP pelo Conselho Nacional de Educação que não tinha como objetivo construir uma proposta pedagogicamente mais avançada e preocupada com os interesses e necessidades dos educandos, futuros trabalhadores, mas apenas ajustar o texto às últimas alterações legais:

A proposta do Parecer Cordão [...] à atualização das DCNEP, inicia-se com um histórico da Educação Profissional Técnica de Nível Médio a partir da LDB de 1996, destacando o conjunto de regulamentações provocadas pelo dec. n. 2.208/97. Curiosamente, ressalta que essas permaneceram plenamente compatíveis com o dec. n. 5.154/2004, o que teria exigido do Conselho somente sua atualização promovida pelo Parecer CNE/CEB n. 39/2004. Nesse momento, a finalidade de um novo parecer seria principalmente explicitar orientações complementares em relação a eventuais divergências, considerando, inclusive, as alterações introduzidas pela lei n. 11.741/2008 (CIAVATTA; RAMOS, 2012, p. 20, grifo nosso).

Esse percurso inicial controvertido, que começou com a apresentação de um texto já pronto, poderia ter consequências ainda mais prejudiciais, não fosse a manifestação de setores da sociedade civil, que se articularam e contribuíram com o debate por meio do documento DIRETRIZES CURRICULARES NACIONAIS PARA A EDUCAÇÃO PROFISSIONAL TÉCNICA DE NÍVEL MÉDIO EM DEBATE - texto para discussão. ${ }^{4}$

A versão oficial preliminar que circulou durante as discussões estava marcada pelo foco no desenvolvimento de competências e pela desconsideração da articulação teórico-prática da formação humana:

0 art. $6^{0}$ da Resolução CNE/CEB nº 4/99 já estabelecia que 0 desenvolvimento de competência profissional é 0 compromisso ético das instituições de Educação Profissional e Tecnológica para com seus alunos e a sociedade beneficiária de seu trabalho profissional, devendo ser entendido no sentido de promoção da "capacidade de mobilizar, articular e colocar em ação, valores, habilidades e conhecimentos necessários para o desempenho eficiente e eficaz de atividades requeridas pela natureza do trabalho" (MEC, DCNEP versão em discussão em 2011, p. 22, e posteriormente substituída, grifo nosso)5.

\footnotetext{
4 Esse texto surgiu no âmbito de Grupo de Trabalho que contou com a participação de gestores estaduais de Educação Profissional vinculados ao Conselho Nacional dos Secretários de Educação (CONSED); do Fórum dos Conselhos Estaduais de Educação; do Conselho Nacional das Instituições da Rede Federal de Educação Profissional, Científica e Tecnológica (CONIF); da Central Única dos Trabalhadores (CUT), representada pela Escola dos Trabalhadores; do Sindicato Nacional dos Servidores Federais da Educação Básica, Profissional e Tecnológica (SINASEFE); da Associação Nacional de Pós-Graduação e Pesquisa em Educação (ANPEd), e a colaboração de renomados pesquisadores da Educação Profissional e tecnológica. Também participaram, no âmbito do governo federal, quatro Secretarias do MEC, o Ministério do Trabalho e Emprego (MTE) e o Ministério da Saúde (MS), representado pela Escola Politécnica de Saúde Joaquim Venâncio (EPSJV - Fiocruz). No presente texto a autoria deste Documento será referida como Coletivo Social (BERNARDIM, 2013).

5 Trata-se da versão que circulou nos bastidores do Conselho Nacional de Educação e que foi motivo de crítica nos meios intelectuais, sofrendo inúmeras alterações até que se chegasse ao Parecer 11/2012 CNE/CEB, aprovado em 09.05.2012. As várias versões do texto das atuais DCNEP são emblemáticas do embate de concepções e das disputas em torno da definição da política curricular para a educação básica, notadamente, para 0 Ensino Médio e para a Educação Profissional Técnica de Nível Médio. A esse respeito sugere-se a leitura do artigo de Ramos, M. e Ciavatta intitulado "A 'era das diretrizes': a disputa pelo projeto de educação dos mais pobres" publicado na Revista Brasileira de Educação, v. 17, n 49, jan-abr de 2012.
} 
O maior tempo requerido para a discussão e a apreciação pela CEB/CNE parece ter sido oportuno para aprimorar o texto e eliminar trechos como o acima transcrito, que limitavam bastante as possibilidades da Educação Profissional. Apenas esse exemplo já antecipava os problemas que permaneceriam no texto dessas diretrizes, não fosse a crítica de um grande número de entidades e intelectuais preocupados com a educação dos jovens e dos trabalhadores, e que se manifestaram por meio do documento mencionado.

Logo, no interstício de treze anos entre as primeiras diretrizes e a sua recente revisão persistem preocupações, tensionamentos e controvérsias no que diz respeito à relação entre mudanças na base material, mudanças no mundo do trabalho e o direcionamento das políticas educacionais.

Outro aspecto que merece menção diz respeito a que, embora fundamental na constituição do ser humano e na construção de uma nova sociedade, a educação escolar não pode ser responsabilizada pelos problemas sociais, visto que também ela é determinada historicamente nos planos infra e superestruturais, conforme destaca o texto que faz análise crítica à versão das diretrizes apresentada pelo Conselheiro Cordão, de 2010:

[...] deve ser rejeitada a concepção que vê a educação como salvação do país e a Educação Profissional e tecnológica como a porta da empregabilidade, entendida como condição individual necessária ao ingresso e permanência no mercado de trabalho, de responsabilidade exclusiva dos trabalhadores (COLETIVO SOCIAL, 2010, p. 39).

Não se trata de negar o papel importante da escola para a formação das novas gerações e para a construção de uma sociedade justa, mas sim de relativizar o seu poder em um mundo marcado pela mercantilização das coisas e das relações.

Nesse sentido, se as DCNEM de 2012 apresentam avanços, e se aproximam das concepções e propostas do Documento Referência da Conae 2014, o mesmo não se pode dizer das DCNEP aprovadas também em 2012 , cujos aspectos mais críticos foram apontados por intelectuais, educadores e trabalhadores da educação, durante o período de sua elaboração, análise e discussão no CNE. Em síntese, os pontos mais sensíveis assinalados pelo Grupo de Trabalho anteriormente identificado e aqui denominado de Coletivo Social (2010), são:

- Centralidade formativa na dimensão econômica e aceitação do mercado como instrumento regulador da sociabilidade humana;

- Insistência no modelo de Educação Profissional centrado no desenvolvimento de competências profissionais e abandono da perspectiva de formação politécnica;

- Aceitação de uma inserção subserviente da sociedade brasileira na divisão internacional do trabalho;

- Concepção de desenvolvimento produtivista, centrado na produção destrutiva e não na socialização dos bens e distribuição da riqueza que assegurem uma vida digna a todos.

A não explicitação, no texto da resolução que homologa as atuais DCNEP, de elementos que remetam à necessidade de formação integral e integrada, da tomada do trabalho como princípio educativo, e da ciência, da tecnologia, da cultura e do trabalho como categorias orientadoras do currículo, é sintomática das dificuldades de se implementar um projeto de Educação Profissional que não esteja restrita à lógica mercantil.

Considera-se estas questões fundamentais quando o que está em disputa é o projeto de formação dos jovens e dos trabalhadores. Logo, a Educação Profissional a ser abraçada pela escola pública, de caráter universal e de concepção politécnica, ainda que carregue as marcas do tempo presente e esteja inserida na sociedade capitalista, converge com a proposição do Coletivo Social de que a escola pode e deve sinalizar para a superação de sua estreita subordinação à lógica mercantil e à racionalidade econômica.

O desvelamento das relações obscurecidas pelo sistema mercantil é o pressuposto que orienta a proposição de educação que se pretende integrada, politécnica, tecnológica, e emancipatória. Se o trabalho é central, precisa ser assimilado de modo a ultrapassar o senso comum que o vincula à mera profissionalização para o sistema produtivo e o reduz a um simulacro das possibilidades de realização das necessidades humanas. Esta é a perspectiva que está anunciada e assumida pelo Documento Referência da Conferência Nacional de Educação - Conae 2014. 


\section{A título de conclusão}

O Parecer 05/2011 do CNE/CEB parte do reconhecimento de que as novas Diretrizes Curriculares Nacionais para o Ensino Médio estão ancoradas na necessidade de conferir outra dinâmica a essa etapa da educação básica e de buscar novas formas de organização do currículo com vistas à ressignificação dos saberes escolares para que sejam capazes de conferir qualidade e ampliar a permanência dos jovens na escola. Nesse sentido, o texto normativo traz um conjunto de argumentações que buscam qualificar e contextualizar suas proposições: a educação como direito social; o Ensino Médio com qualidade social; o sentido da escola para as "juventudes"; as especificidades do Ensino Médio noturno, da educação de jovens e adultos, dos quilombolas, indígenas e do campo, os estudantes da educação especial, estão entre os argumentos que explicam as propostas para a organização curricular segundo essas diretrizes. Nesses aspectos, as atuais diretrizes para o Ensino Médio se aproximam, reiteram e valorizam as formulações constantes do Documento Referência da Conae 2014.

A indicação de afastamento do uso do termo "qualidade" no sentido da racionalidade, eficiência e produtividade, passando a ser tomado no sentido de "qualidade social", que expressa a democratização do acesso, o compromisso e a responsabilidade social, também aponta para a convergência com os interesses do público que se ressente da conclusão da educação básica, público este alçado à prioridade nos debates que culminaram com a elaboração do documento da Conae.

Nesse sentido, levando-se em conta o contexto socioeconômico em que foram concebidas, as atuais DCNEM (2012) sinalizam, em comparação com a sua versão anterior (1998), uma visão mais clara e posicionamento mais crítico quanto à necessidade de um esforço articulado entre tipos e níveis de educação, formal ou não, como resposta à educação continuada demandada pela contemporaneidade, mas não restrita ao mercado de trabalho, preocupação sinalizada reiteradamente no Documento Referência da Conae 2014.

As bases conceituais sobre as quais se ancoram as novas Diretrizes para o Ensino Médio tomam o trabalho como princípio educativo, a pesquisa como princípio pedagógico e o eixo ciência-cultura-trabalho-tecnologia como fundamento da organização pedagógico-curricular do Ensino Médio. Tais proposições recuperam a ideia de formação politécnica, presente, como mencionado, nos debates que antecederam a elaboração da atual LDB. Aqui, uma vez mais, se assevera a proximidade de concepções entre a política curricular para o Ensino Médio e as formulações que orientaram a realização da Conferência Nacional de Educação no ano de 2014.

No caso das novas Diretrizes Curriculares Nacionais para a Educação Profissional e dos pareceres e resoluções que Ihes deram caráter normativo (2011/2012), quando comparadas com a sua versão anterior (1999) e, ainda, cotejadas com a proposta de DCNEP feita pelo Coletivo Social, revelam que a manutenção de percursos fragmentados e desarticulados entre si fere os princípios de integração reivindicados para a escola politécnica. Além disso, o forte apelo de formação voltada aos interesses do mercado de trabalho sinaliza a persistência de um tangenciamento da escola aos interesses do empresariado e ao aprofundamento da divisão social do trabalho. Nesse aspecto ele se distancia significativamente das proposições presentes no Documento Referência da Conae 2014, amplamente debatidas pela sociedade brasileira ao longo das conferências municipais e estaduais, e reiteradas na Conferência Nacional de novembro de 2014.

Embora as novas diretrizes para a Educação Profissional não observem os pressupostos da educação politécnica que atenda aos anseios da(s) juventude(s), de certa forma representam avanços quanto à flexibilidade na organização curricular, introduzindo a ampliação do tempo de integralização como vantagem a ser considerada quando se leva em conta as especificidades dos alunos, em especial dos trabalhadores. Se isso não é suficiente, deve-se considerar que a Educação Profissional Técnica de Nível Médio de oferta integrada apresenta-se como alternativa historicamente viável para a última etapa da educação básica. Por essa razão se confere especial sentido e relevância para as propostas do documento base da Conae 2014. 


\section{Referências}

BERNARDIM, M. L. Juventude, escola e trabalho: sentidos atribuídos ao Ensino Médio integrado por jovens da classe trabalhadora. Curitiba: UFPR, 2013. (Tese de Doutorado).

BRASIL. Fórum Nacional de Educação. CONAE 2014. Documento Referência. Brasília, 2014. Disponível em http://conae2014.mec.gov.br/images/pdf/doc referencia.pdf. Acesso em 12 de dezembro de 2014.

Decreto $\mathbf{n}^{\circ} \mathbf{2 . 2 0 8}$, de 17 de abril de 1997. Regulamenta o $\S 2^{\circ}$ do art. 36 e os arts. 39 a 42 da Lei $n^{\circ}$ 9.394, de 20 de dezembro de 1996, que estabelece as diretrizes e bases da educação nacional. D.O.U., Brasília, 18 abr. 1997. Disponível em: www.planalto.gov.br/ccivil 03/decreto/D2208.htm. Acesso em: 10 jun. 2013.

Decreto $n^{\circ} \mathbf{5 . 1 5 4}$, de 23 de julho de 2004. Regulamenta o $\S 2^{\circ}$ do art. 36 e os arts. 39 a 41 da Lei no 9.394, de 20 de dezembro de 1996, que estabelece as diretrizes e bases da educação nacional, e dá outras providências. D.O.U., Brasília, 26 jul. 2004. Disponível em: www.planalto.gov.br/ccivil_03/_Ato2004-2006/2004/ Decreto/D5154.htm. Acesso em: 10 jun. 2013.

Emenda Constitucional $\mathbf{n}^{\circ} \mathbf{5 9}$, de 11 de novembro de 2009. Acrescenta $\S 3^{\circ}$ ao art. 76 do Ato das Disposições Constitucionais Transitórias para reduzir, anualmente, a partir do exercício de 2009, o percentual da Desvinculação das Receitas da União incidente sobre os recursos destinados à manutenção e desenvolvimento do ensino de que trata o art. 212 da Constituição Federal, dá nova redação aos incisos I e VII do art. 208, de forma a prever a obrigatoriedade do ensino de quatro a dezessete anos e ampliar a abrangência dos programas suplementares para todas as etapas da educação básica, e dá nova redação ao $\S 4^{\circ}$ do art. 211 e ao $\S 3^{\circ}$ do art. 212 e ao caput do art. 214, com a inserção neste dispositivo de inciso VI. Disponível em: http://www.planalto. gov.br/ccivil 03/constituicao/Emendas/Emc/emc59.htm. Acesso em: 23 jul. 2014.

Lei $\mathbf{n}^{\circ} \mathbf{9 . 3 9 4}$, de 20 de dezembro de 1996. Estabelece as diretrizes e bases da educação nacional. D.O.U., Brasília, 23 dez. 1996. Disponível em: www.planalto.gov.br/ccivil 03/Leis/L9394.htm. Acesso em: 10 jun. 2013.

Lei $\mathbf{n}^{\circ} \mathbf{1 0 . 1 7 2}$, de 9 de janeiro de 2001. Aprova o Plano Nacional de Educação e dá outras providências. D.O.U., Brasília, 10 jan. 2001. Disponível em: http://www.planalto.gov.br/ccivil 03/leis/leis 2001/l10172.htm. Acesso em: 23 jul. 2014.

Lei $\mathbf{n}^{\mathbf{1}} \mathbf{1 3 . 0 0 5}$, de 25 de junho de 2014. Aprova o Plano Nacional de Educação - PNE e dá outras providências.D.O.U., Brasília, 26 jun. 2014. Disponível em: http://www.planalto.gov.br/ccivil 03/ Ato20112014/2014/Lei/L13005.htm. Acesso em: 23 jul. 2014.

. Conselho Nacional de Educação. Parecer CNE/CEB n 15, de $1^{\circ}$ de junho de 1998. Trata das Diretrizes Curriculares Nacionais para o Ensino Médio. Brasília: 1998.

. Conselho Nacional de Educação. Parecer CNE/CEB n 16, de 5 de outubro de 1999. Trata das

Diretrizes Curriculares Nacionais para a Educação Profissional Técnica de Nível Médio. Brasília: 1999.

Conselho Nacional de Educação. Parecer CNE/CEB nº 5, de 4 de maio de 2011. Trata das Diretrizes

Curriculares Nacionais para o Ensino Médio. Brasília: 2011.

Conselho Nacional de Educação. Parecer CNE/CEB n 11, de 9 de maio de 2012. Trata das Diretrizes Curriculares Nacionais para a Educação Profissional Técnica de Nível Médio. Brasília: 2012.

Conselho Nacional de Educação. Resolução CNE/CEB n 3, de 26 de junho de 1998. Institui as Diretrizes Curriculares Nacionais para o Ensino Médio. Brasília: 1998. Disponível em: http://portal.mec.gov.br/ cne/arquivos/pdf/rceb03 98.pdf. Acesso em: 25 out. 2012.

Conselho Nacional de Educação. Resolução CNE/CEB n 4, de 8 de dezembro de 1999. Institui as Diretrizes Curriculares Nacionais para a Educação Profissional. Brasília, 1999. Disponível em: http://portal.mec. gov.br/dmdocuments/rceb004 99.pdf. Acesso em: 29 set. 2013.

Conselho Nacional de Educação. Resolução CNE/CEB $\mathbf{n}^{\circ}$ 2, de 30 de janeiro de 2012. Define 
Diretrizes Curriculares Nacionais para o Ensino Médio. D. O. U., Brasília, 31 jan. 2012, Seção 1, p. 20. Disponível em: $\quad$ http://www.sinepe-pe.org.br/wp-content/uploads/2012/05/Resolucao CNE 022012 Ensino Medio.pdf. Acesso em: 10 jun. 2013.

Conselho Nacional de Educação. Resolução CNE/CEB n 6, de 20 de setembro de 2012. Define Diretrizes Curriculares para a Educação Profissional. D.O.U., Brasília, 21 set. 2012, Seção 1, p. 22. Disponível em: http://curitiba.ifpr.edu.br/wp-content/uploads/2011/06/resolu\%C3\%A7\%C3\%A3o-DIRETRIZES-EDUCACAOPROFISSIONAL-6 12-ATUAL.pdf. Acesso em: 10 jun. 2013.

MEC. Conselho Nacional de Educação. Texto preliminar das Diretrizes Curriculares Nacionais para a Educação Profissional Técnica de Nível Médio. Brasília: CNE, 2010. Texto do relator Francisco A. Cordão, que esteve em discussão entre 2011 e 2012, e foi substituído. Disponível em: http://forumeja.org.br/ sites/forumeja.org.br/files/versaopreliminaraudipublinaciona.PDF. Acesso em: 28 set. 2013.

MEC. Parâmetros Curriculares Nacionais para o Ensino Médio. Brasília: MEC, 1999.

CIAVATTA, M. A formação integrada: a escola e o trabalho como lugares de memória e de identidade. In: FRIGOTTO, G.; CIAVATTA, M.; RAMOS, M. (org.). Ensino Médio integrado: concepção e contradições. São Paulo: Cortez, 2005.

CIAVATTA, M.; RAMOS, M. A "era das diretrizes": a disputa pelo projeto de educação dos mais pobres. In: Revista Brasileira de Educação, v. 17, n. 49, jan.-abr. 2012.

COLETIVO SOCIAL. Diretrizes curriculares nacionais para a Educação Profissional Técnica de Nível Médio em debate. Texto para discussão. Brasília. 2010. Disponível em: https://www.google.com/url?sa=t\&rct=j\& $q=\& e s r c=s \&$ source $=$ web\&cd $=1 \& v e d=0 C C 0 Q F j A A \& u r l=h t t p \% 3 A \% 2 F \% 2 F p o r t a l$. mec.gov.br\%2Findex.php\%3FI temid\%3D\%26gid\%3D6695\%26option\%3Dcom docman\%26task\%3Ddoc download\&ei=6ji3UdXXHKSU0QH3 6oGABw\&usg=AFQjCNESIC wOTTz QgJ2RIvQgoLvX9MWw\&sig2=Tgsq7ao2veKIMVumWMnM3g\&bvm=bv.47 534661,d.dmQ. Acesso em: 10 jun. 2013.

FERRETI, C. J. Mudanças no âmbito do trabalho, juventude e escolhas profissionais. In: FERREIRA Cristina et al (orgs). Juventude e iniciação científica: políticas públicas para o Ensino Médio. Rio de Janeiro: EPSJV; UFRJ, 2010.

FRIGOTTO, G.; CIAVATTA, M.; RAMOS, M. (org.). Ensino Médio integrado: concepções e contradições. São Paulo: Cortez, 2005.

INEP. MEC. Sinopse Estatística da Educação Básica. 2013. Disponível em: http://portal.inep.gov.br/basicacenso-escolar-sinopse-sinopse. Acesso em 15 jul. 2014.

Censo da Educação Básica 2013. Brasília: MEC, INEP, 2014. Disponível em http://download.inep.gov. br/educacao basica/censo escolar/apresentacao/2014/apresentacao coletiva censo edu basica 022014. pdf. Acesso em 15 de dezembro de 2014.

MACHADO, L. Politecnia, escola unitária e trabalho. São Paulo, Autores Associados, 1989.

SILVA, M. R. Competências: fluidez e ambigüidades para administrar a formação do trabalhador. In: $27^{\mathbf{a}}$ Reunião Anual da ANPED, 2004, Caxambu - MG. Sociedade, Democracia e Educação. Qual Universidade? 2004, p. 01-17.

Currículo e competências: a formação administrada. São Paulo: Cortez, 2008.

Perspectivas Curriculares Contemporâneas. Curitiba: Editora Ibpex, 2012.

Tecnologia, trabalho e formação na reforma curricular do Ensino Médio. Cadernos de Pesquisa,

v. 39, n.137, p.441-460, maio/ago. 2009. Disponível em: http://www.scielo.br/scielo.php?pid=S0100$15742009000200007 \&$ script=sci arttext. Acesso em: 24 jul. 2014.

Recebido em novembro de 2014 - Aprovado em dezembro de 2014 


\title{
Gestão democrática, participação popular e controle social: análise das emendas paranaenses ao documento referência da Conae 2014
}

\author{
Democratic Administration, popular participation and social \\ control: analysis of the Paraná state's amendments to the \\ Reference Document of Conae 2014
}

Gestión democrática, participación popular y control social: análisis de las enmiendas del Estado del Paraná a el Documento Referencia de la Conae 2014

\section{Adriana Dragone Silveira' Taís Moura Tavares ${ }^{2}$}

\section{Resumo}

Este artigo tem por objetivo apresentar uma análise das propostas de emendas paranaenses ao Documento Referência da Conferência Nacional de Educação (Conae) 2014, para o eixo "Gestão democrática, participação popular e controle social". O caderno de emendas preparado para a discussão na Conferência Estadual de Educação do Paraná, para o eixo em destaque constou com 356 sugestões. Da análise se destacam as emendas referentes: à participação popular por meio de Conselhos; sobre os mecanismos de participação na promoção da democratização da gestão dos sistemas de ensino e das instituições escolares; ao destaque do setor público na gestão da educação e dos seus recursos; à alternância nos postos de gestão das instituições escolares e à autonomia da escola na gestão dos recursos financeiros.

Palavras-chave: Gestão democrática; Participação popular; Controle social; Conae 2014;

\begin{abstract}
This article aims to present an analysis of the state of Paraná proposed amendments to the Reference Document of the National Conference on Education (Conae) in 2014, to the theme "Democratic administration, popular participation and social control". The amendments documents prepared for discussion at the Paraná State Conference of Education consisted with 356 suggestions. From the analysis we highlight the related amendments: popular participation through councils; about the mechanisms of involvement in promoting democratization of the management of education systems and school institutions; the highlight of the public sector in management education and its resources; the alternation in principal's at public schools positions; and school autonomy in the management of financial resources.
\end{abstract}

Keywords: Democratic administration; Popular participation; Social control; Conae 2014.

1 Doutora em educação, professora e pesquisadora do Núcleo de Políticas Educacionais (NuPE) e do Programa de Pós-Graduação em Educação (PPGE) da UFPR; e-mail: adrianadragone@yahoo.com.br

2 Doutora em educação, professora e pesquisadora do Núcleo de Políticas Educacionais (NuPE) e do Programa de Pós-Graduação em Educação (PPGE) da UFPR; e-mail: tavarestais@gmail.com 


\section{Resumen}

Este artículo tiene como objetivo presentar un análisis de las propuestas de enmienda hechas por el estado de Paraná al documento de referencia de la Conferencia Nacional de Educación (Conae) en 2014, sobre el eje "Gestión democrática, la participación popular y el control social". Los documentos preparados para su discusión en la Conferencia de Educación del Estado de Paraná, para el eje consistían con 356 sugerencias de alteración. Del análisis se destacan las modificaciones relacionadas: la participación popular a través de los consejos; sobre los mecanismos de participación en la promoción de la democratización de la gestión de los sistemas educativos y las instituciones escolares; el destaque del sector público en la gestión de la educación y sus recursos; la alternancia en los cargos directivos de las instituciones educativas; y la autonomía escolar en la gestión de los recursos financieros.

Palabras-clave: Gestión democrática; Participación popular; Control social; Conae 2014.

A aceitação da democracia como valor nos processos de definição dos rumos das sociedades modernas é hoje consensual. No Brasil, marcado por vários episódios de regimes de exceção, em que direitos civis e políticos foram restringidos por governos autoritários, atingimos um estágio em que todos se declaram democráticos.

Nos parâmetros do estado liberal, a democracia constitui-se a partir de alguns critérios ainda não consolidados na prática e na cultura política brasileira. Segundo Robert Dahl (2001), os critérios de um processo democrático são cinco: a) participação efetiva, entendida como iguais oportunidades de que cada um possa expressar sua posição; b) igualdade de voto; c) entendimento esclarecido, ou seja, oportunidades de compreender as alternativas em disputa e suas consequências; d) exercício do controle efetivo sobre o planejamento das políticas; e) inclusão de todos os adultos nos processos decisórios. A base desses critérios é o princípio da igualdade intrínseca:

"Devemos considerar o bem de cada ser humano intrinsecamente igual ao de qualquer um". [...] como julgamento moral insistimos que a vida, a liberdade e a felicidade de uma pessoa não são intrinsecamente superiores ou inferiores às de qualquer outra. Consequentemente, devemos tratar todas as pessoas como se possuíssem igual direito à vida, à liberdade, à felicidade e a outros bens e interesses fundamentais. Chamarei esse julgamento moral de princípio da igualdade intrínseca (DAHL, 2001, p.78, grifos do autor).

Pode um país com históricas desigualdades sociais, culturais e econômicas ser efetivamente democrático? Ultrapassar a democracia formal estabelecida no plano legal na direção de uma democracia efetiva tem sido o desafio no contexto atual, tanto no plano do funcionamento do Estado e da sua relação com a sociedade civil, quanto no que se refere especificamente à democratização da educação.

Com a redemocratização da sociedade brasileira, no final dos anos 1970 e 1980, as demandas em educação centram-se na democratização do acesso à educação, na defesa do ensino público de qualidade e na participação popular na gestão da educação e da escola, visando romper com as práticas autoritárias e centralizadoras, de participação restrita e formal, construindo e aperfeiçoando espaços democráticos para a partilha do poder e controle social.

Na Constituição Federal de 1988, a República Federativa do Brasil constitui-se em Estado Democrático de Direito. Segundo José Afonso da Silva (2001), um Estado de Direito tem como características básicas a submissão do poder estatal à lei, a separação de poderes e a enunciação e a garantia dos direitos individuais. Já um Estado Democrático tem como base o princípio da soberania popular na formação das instituições representativas, mas também visa à garantia dos direitos fundamentais da pessoa humana como realização do princípio democrático. Na definição do Estado brasileiro, a expressão "democrático de direito" tem como pressuposto que o 'democrático' qualifique o Estado, portanto irradiando os valores da democracia sobre todos os elementos constitutivos do Estado e também sobre a ordem jurídica" (SILVA, 2001, p.123). 
Quando refletimos sobre o campo da educação e da escola, observamos que os princípios democráticos presentes na Constituição Federal estendem-se aos processos educacionais. Neste sentido, sendo a democracia a base do Estado brasileiro e das suas instituições, o princípio da "gestão democrática do ensino público" é um reforço à concepção de Estado brasileiro adotado pela Carta Constitucional de 1988.

A Lei de Diretrizes e Bases da Educação Nacional (LDB), de 1996, reafirma como princípio "a gestão democrática do ensino público na forma desta Lei e da legislação dos sistemas de ensino" (BRASIL, 1996, art. $3^{\circ}$, VIII). E no artigo 14 estabelece os princípios norteadores das "normas de gestão democrática do ensino público na educação básica" pelos sistemas de ensino:

I - participação dos profissionais da educação na elaboração do projeto pedagógico da escola;

II - participação das comunidades escolar e local em conselhos escolares ou equivalentes (BRASIL, 1996, art. 14).

Vemos aqui como o plano legal ainda apresenta restrições à participação de todos, contrariando os princípios anteriormente expostos: a participação para a elaboração do projeto pedagógico, segundo a LDB restringe-se aos profissionais da educação. Nesse sentido, apresenta um retrocesso, em termos conceituais, ao estabelecido pelo Estatuto da Criança e do Adolescente (ECA), de 1990, que assegura como "direito dos pais ou responsáveis ter ciência do processo pedagógico, bem como participar da definição das propostas educacionais" (art. 53, parágrafo único).

O sentido de autonomia também é marcado por controvérsias. A autonomia é um elemento fundamental no exercício da democracia, com participação de seus usuários na tomada de decisões, no sentido, como afirma Paro (2001, p. 84), "que a escola seja detentora de um mínimo de poder de decisão que possa ser compartilhado com seus usuários com a finalidade de servi-los de maneira mais efetiva". A LDB trata da autonomia das escolas face aos sistemas de ensino:

Os sistemas de ensino assegurão às unidades escolares públicas de educação básica que os integram progressivos graus de autonomia pedagógica e administrativa e de gestão financeira, observadas as normas gerais do direito financeiro público (BRASIL, 1996, art. 15).

Entretanto, é preciso considerar que essa autonomia é sempre "relativa", pois a escola segue a legislação referente às normas do direito administrativo e público e no aspecto pedagógico as bases mínimas de conteúdos curriculares nacionais. É essa base que assegura, por outro lado, a unidade de qualidade que atende ao princípio de igualdade.

Ao mesmo tempo, a "autonomia da escola" tem sido mecanismo de aprofundamento das desigualdades quando serve para justificar processos de desresponsabilização do poder público em relação à manutenção das unidades escolares. Cabe ressaltar que autonomia não pode ser confundida, como destaca Paro (2001, p. 83-4), com "abandono e privatização" no que concerne ao Estado ser desresponsabilizado de suas tarefas e "descentralização de poder" com "desconcentração das atividades e procedimentos de cunho meramente executivo", devendo a escola ser detentora de "um mínimo de poder de decisão que possa ser compartilhado com seus usuários".

Os múltiplos sentidos com os quais têm sido usados os termos como "autonomia" e "participação" intensificam a disputa pelos conceitos do que seja "democrático" no campo da sociedade e consequentemente da escola. Essa disputa tem sido objeto da reflexão teórica, mas também da proposição e realização de novas práticas no interior das instituições escolares e sistemas de ensino que se expressam nos espaços coletivos de definições sobre as políticas educacionais como foi o caso da Conferência Nacional de Educação (Conae).

Visando à construção e ao aperfeiçoamento dos espaços democráticos de controle social e de tomada de decisão, algumas experiências se destacam, como a realização de assembleia da comunidade escolar; constituição e fortalecimento das atribuições do conselho de escola e grêmio estudantil; participação da comunidade local e escolar, inclusive de pais, comunidade e alunos, na elaboração e implementação do projeto político pedagógico, regimento escolar e currículo; orçamento escolar democrático; eleição/escolha dos dirigentes escolares por meio de consulta aos usuários. Alguns desses processos estão destacados no Documento Referência da Conae 2014: 
Ao conceber a educação e as instituições educativas como espaço público de expressão de concepções e interesses múltiplos, a perspectiva democrática pressupõe uma estrutura organizacional diferente daquela defendida e praticada pela visão conservadora. Na perspectiva democrática, a educação e as instituições educacionais passariam a considerar a horizontalidade nas relações de poder, a alternância nos postos de comando e das funções a serem desempenhadas, a visão geral dos objetivos a realizar e a solidariedade na execução de suas ações, para alcançar os objetivos coletivamente definidos e a qualidade socialmente referendada (BRASIL, 2013, p. 68).

A democratização da gestão educacional visa romper com tradições e lógicas autoritárias e centralizadoras, para tanto se faz necessária a participação popular, com a representação paritária dos diferentes atores, tanto nos colegiados escolares por professores, funcionários, alunos, pais e comunidade, como nos fóruns e conselhos decisórios de políticas públicas educacionais por gestores públicos, trabalhadores e organizações da sociedade civil. Outro elemento essencial para a participação relaciona-se aos processos democráticos de escolha dos representantes, coibindo práticas de indicação e/ou direcionamento dos participantes destes conselhos e fóruns, assim como na proibição de parentes dos gestores públicos na sua composição, pois a manutenção destas práticas não garante "o controle social dos processos educativos, o compartilhamento das decisões e do poder, configurando-se muito mais como mecanismo legitimador de decisões já tomadas centralmente" (BRASIL, 2013, p. 68).

Outro aspecto fundamental para a construção da democracia em nossas instituições refere-se ao controle social. Para tanto, se faz necessário aperfeiçoar o papel fiscalizador dos recursos públicos educacionais dos Conselhos Estaduais e Municipais de Educação, com transparência na aplicação dos recursos públicos, pelos órgãos administrativos centrais e também pelas unidades escolares, com publicização dos orçamentos e das prestações de contas em linguagem acessível, assim como a realização de audiências públicas. Nesse processo é essencial que os conselhos se fortaleçam em suas funções e seus membros sejam capacitados.

Considerando que a democracia "nunca é o fruto de uma evolução natural e inelutável da sociedade política", mas se "institucionaliza ao longo de um incessante e penoso trabalho de modelagem das instituições políticas, em defesa da dignidade humana" (COMPARATO, 1998, p.48), a realização das conferências municipais e estaduais, com ampla participação popular, como meio de preparação para a Conae/2014, nas quais se debateram concepções, proposições e estratégias para o eixo "Gestão democrática, participação popular e controle social", constituiu um importante mecanismo para o fortalecimento da democracia na educação e em nosso país. Dessa forma, este artigo tem por objetivo apresentar uma análise das propostas de emendas paranaenses ao Documento Referência da Conae 2014 referentes a este eixo.

\section{Propostas de emendas das Conferências Municipais e Intermunicipais do estado do Paraná para o eixo "Gestão Democrática, participação popular e controle social"}

O estado do Paraná realizou 220 conferências municipais e intermunicipais, o que demonstra a forte mobilização no estado para a discussão do Documento Referência da Conae 2014, como um elemento fundamental para a consolidação da democratização da gestão na educação, por meio da discussão coletiva das políticas educacionais. Ao todo foram 18.000 propostas de emendas ao documento.

O caderno de emendas (PARANÁ, 2013) preparado para a discussão na Conferência Estadual de Educação do Paraná, ocorrida em setembro de 2013, compõe-se de dois volumes: I) das emendas aprovadas em no mínimo 20\% ou 44 conferências municipais que o Fórum Estadual de Educação recomenda à aprovação; II) das emendas passíveis de destaque na Conferência Estadual do Paraná, aprovadas em menos de $20 \%$ ou 44 conferências municipais ou intermunicipais.

Para o Eixo V "Gestão democrática, participação popular e controle social", das emendas com aprovação em no mínimo 20\% das conferências municipais e que o Fórum Estadual de Educação recomendou para aprovação, houve somente uma, que tratava da ampliação dos programas de apoio e formação aos/às conselheiros/as, de caráter supressivo, pois havia coincidência entre dois parágrafos. 
Já as emendas deste eixo, aprovadas em menos de 20\% das conferências, totalizaram 356 propostas no estado do Paraná, conforme quadro a seguir. O maior percentual de alterações concentrou-se em emendas aditivas. Com exceção de dois parágrafos deste eixo (350 e 360), nos quais não houve proposta de modificação ao texto do documento referência, todos os demais apresentaram sugestões.

Quadro 1 - Quantitativo das emendas propostas ao Eixo V "Gestão democrática, participação popular e controle social”

\begin{tabular}{|c|c|c|c|c|}
\hline PARÁGRAFOS & $\begin{array}{l}\text { QUANTIDADE DE } \\
\text { EMENDAS }\end{array}$ & $\begin{array}{c}\text { EMENDAS } \\
\text { SUPRESSIVAS }\end{array}$ & EMENDA: ADITIVA & $\begin{array}{l}\text { TIPO DE EMENDA } \\
\text { SUBSTITUTIVA }\end{array}$ \\
\hline 349 & 1 & 0 & 1 & 0 \\
\hline 350 & 3 & 0 & 3 & 0 \\
\hline 351 & 0 & 0 & 0 & 0 \\
\hline 352 & 2 & 0 & 1 & 1 \\
\hline 353 & 6 & 2 & 3 & 1 \\
\hline 354 & 4 & & 4 & 0 \\
\hline 355 & 6 & 2 & 3 & 1 \\
\hline 356 & 8 & 0 & 5 & 3 \\
\hline 357 & 2 & 0 & 2 & 0 \\
\hline 358 & 2 & 0 & 1 & 1 \\
\hline 359 & 2 & 0 & 1 & 1 \\
\hline 360 & 0 & 0 & 0 & 0 \\
\hline 361 & 26 & 0 & 23 & 3 \\
\hline 362 & 21 & 2 & 13 & 6 \\
\hline 363 & 46 & 4 & 24 & 18 \\
\hline 364 & 18 & 1 & 16 & 1 \\
\hline 365 & 17 & 2 & 12 & 3 \\
\hline 366 & 13 & 0 & 13 & 0 \\
\hline 367 & 14 & 2 & 12 & 0 \\
\hline 368 & 19 & 2 & 16 & 1 \\
\hline 369 & 9 & 2 & 4 & 3 \\
\hline 370 & 12 & 1 & 9 & 2 \\
\hline 371 & 6 & 1 & 4 & 1 \\
\hline 372 & 13 & 1 & 12 & 0 \\
\hline 373 & 12 & 0 & 11 & 1 \\
\hline 374 & 9 & 1 & 8 & 0 \\
\hline 375 & 15 & 1 & 12 & 2 \\
\hline 376 & 19 & 1 & 13 & 5 \\
\hline 377 & 7 & 2 & 3 & 2 \\
\hline 378 & 8 & 3 & 5 & 0 \\
\hline 379 & 8 & 0 & 7 & 1 \\
\hline 380 & 12 & 3 & 6 & 3 \\
\hline 381 & 16 & 0 & 15 & 1 \\
\hline TOTAL & 356 & 33 & 262 & 61 \\
\hline
\end{tabular}

Fonte: as autoras com base no Caderno de Emendas (PARANÁ, 2013). 
A maior parte das sugestões estava relacionada às propostas para acrescentar e/ou modificar expressões visando aperfeiçoar o texto na realização das ações, como "implementar", "promover", "estimular", "garantir condições técnicas e financeiras". Outras reforçaram a importância da gestão democrática em todas as instituições educacionais, assim com o fortalecimento dos mecanismos de participação e controle social. A seguir apresenta-se análise de algumas dessas emendas.

\section{Participação popular por meio de conselhos}

A proposta de criação de uma comissão nas escolas sobre meio ambiente e qualidade de vida esteve presente no parágrafo 354, ao propor a inclusão de parágrafo novo:

Através de desenvolvimento efetivo, criar e fortalecer as comissões de meio ambiente e qualidade de vida como espaço colegiado democrático da comunidade escolar, para articulação e fortalecimento das questões socioambientais na gestão das instituições educativas e na sua relação com a sociedade (PARANÁ, 2013, p. 181).

Esta discussão também esteve manifesta no parágrafo 367, que trata especificamente sobre a criação e fortalecimento das "comissões de meio ambiente e qualidade de vida, como espaço colegiado democrático da comunidade escolar [...]" (BRASIL, 2013, p. 70). Algumas emendas tratavam sobre a necessidade de incluir financiamento, assim como condições técnicas e financeiras. Uma emenda propunha suprimir todo o parágrafo, no entendimento de que esses temas devem ser abordados pelos outros conselhos já instituídos nas instituições educacionais.

A necessidade de considerar as especificidades de dinâmicas de participação, por diferentes segmentos da sociedade, foi destacada na emenda ao parágrafo 355 ao propor substituir parte do texto, com a seguinte redação:

[...] tendo em vista que há dinâmicas que se caracterizam pelo envolvimento mais restrito a sujeitos ou grupos determinados e outras que se caracterizam por um movimento mais amplo, mediante o qual se busca democratizar os processos decisórios envolvendo diferentes segmentos da sociedade, que há dinâmicas que se caracterizam pelas ações e as tomadas de decisão por meio do trabalho coletivo (PARANÁ, 2013, p. 181).

Sobre a necessidade de reforçar o papel do Conselho de Escola, como órgão máximo de gestão e administração, uma das emendas propôs adicionar ao final do paragrafo 357, que "[...], o conselho escolar deve ser o órgão máximo de gestão das instituições educacionais". Todavia, esta sugestão restringe-se ao Conselho Escolar, não reforçando o papel dos conselhos na gestão da educação como um todo, o que envolve também a gestão do sistema de ensino.

No parágrafo 369, que tratava sobre "Garantir a representação paritária (movimentos sociais e governo) nos fóruns decisórios de políticas públicas educacionais [...]", as propostas tenderam a alterar a expressão "movimentos sociais" para "populares", "entidades de representação dos pais, comunidade escolar", ou alterar "movimentos sociais e governo" para "de gestores públicos, trabalhadores da educação e organizações da sociedade civil". Houve também a proposição de um parágrafo novo, com a seguinte redação:

9.1. Garantir a paridade nos conselhos de Educação (nacional, estaduais e municipais).

9.2. Garantir que as entidades da sociedade civil que farão parte dos conselhos de educação sejam eleitas em conferência.

9.3. Garantir que as indicações das entidades da sociedade civil na composição dos conselhos de educação sejam respeitadas (PARANÁ, 2013, p. 195).

Em relação ao parágrafo 372, que abordava a criação e consolidação de fóruns e conselhos de educação, as emendas propostas destacaram a necessidade de "garantir as condições técnicas e financeiras" e a "forma paritária" de representação dos setores envolvidos. Mas também apresentaram propostas de exclusão total do parágrafo e inclusão de novo sobre as Associações de Pais e Mestres:

Estimular a constituiçã̃o e fortalecimento de associações de pais e mestres e delegar a esse órgão, autonomia a seus membros, no que diz respeito à função da associação, desde que respeitada as Leis vigentes da Instituição de Ensino, para que possam auxiliar a instituição escolar e a comunidade, na busca de soluções para as situações cotidianas em que a escola na pessoa do gestor, pais e sua equipe pedagógica achar necessário (PARANÁ, 2013, p. 196). 
Sobre a Associação de Pais e Mestres, a emenda ao parágrafo 376 requeria a inclusão da palavra "funcionários", pois este termo está presente nas Associações do Paraná.

Ainda sobre os conselhos, uma das emendas ao parágrafo 358 reforçava a necessidade de capacitação e formação dos membros dos conselhos, ao acrescentar ao final: "criando mecanismos de chamamento, capacitação e formação continuada aos membros da comunidade escolar" (PARANÁ, 2013, p. 182).

Como destacado anteriormente, o parágrafo 364 tratava da "ampliação dos programas de apoio e formação aos/às conselheiros/as" foi suprimido. No entanto, em outras conferências, 18 sugestões foram feitas, entre elas destacam-se as que adicionam a garantia de condições técnicas e financeiras para a formação dos conselheiros, inclusive com a previsão de programas de apoio financeiro da União aos municípios para este fim e criação de incentivos financeiros por meio de bolsas para formação e capacitação dos membros dos referidos conselhos, ainda com a precisão de "incentivo financeiro a cada reunião realizada" (PARANÁ, 2013, p. 190).

As principais propostas ao parágrafo 374 referiam-se à inclusão de apoio técnico e financeiro na ampliação dos "programas de apoio e formação aos conselheiros", mas destaca-se também a proposta de supressão do parágrafo todo.

Ainda sobre a capacitação dos membros dos conselhos escolares, a proposta no parágrafo 361 acrescentava: apoio por meio de pró-labore ou bolsa para a capacitação dos membros dos Conselhos.

\section{Mecanismos de promoção da gestão democrática}

No parágrafo 365 enfatiza-se a criação de "mecanismos de participação que promovam a democratização da gestão dos sistemas de ensino e das instituições educacionais, com a participação dos professores, funcionários técnico-administrativos, estudantes, pais e/ou responsáveis e comunidade local". As emendas destacaram substituir "funcionários técnico-administrativos" para "funcionários", "técnicos de apoio" ou "profissionais da educação". Das emendas que propunham adicionar novo parágrafo, destaca-se a que enfatizava a necessidade de:

[...] efetivar mecanismos de gestão democrática, assegurando: eleições diretas para direção de unidades escolares públicas, realização regulares de fóruns e conferências de educação no âmbito de todos os entes federados e dar condições para a efetiva atuação dos conselhos que representam os diversos segmentos da educação (PARANÁ, 2013, p. 191).

No conjunto de emendas ao parágrafo 379, 24 conferências sugeriram incluir a expressão "estudantes", para além de "gestores públicos, trabalhadores da educação e organizações da sociedade civil" na constituição de fóruns para "debater o financiamento da educação e as diretrizes curriculares nacionais".

As emendas ao parágrafo 380 trataram na sua maioria de inclusão de "fóruns permanentes de educação" e 17 sugestões sobre "fóruns permanentes de educação étnico-racial" para "estimular a constituição e o fortalecimento de conselhos escolares e conselhos municipais de educação, como instrumentos de participação e fiscalização na gestão escolar e educacional, inclusive por meio de programas de formação de conselheiros [...]" (PARANÁ, 2013, p. 201).

Entre as propostas ao parágrafo 366, sobre a institucionalização da Conae, estavam as que propunham adicionar "previsão em calendário escolar"; realização a "cada quatro anos", em "lei federal" e após a garantia de "condições técnicas e financeiras" acrescentar: "suficientes para a realização dos eventos, assegurando ampla participação social" (PARANÁ, 2013, p. 192).

As emendas ao parágrafo 368 discutiram sobre a necessidade de não restringir às instituições federais de ensino superior a garantia de que "tenham Plano de Desenvolvimento Institucional (PDI), assim como o projeto pedagógico curricular dos cursos", desta forma sugeriram incluir estaduais, ou estaduais, municipais e privadas ou ainda retirar a expressão "federais", mas também há proposta de incluir o adjetivo "público".

O parágrafo 377 abordava sobre a necessidade de "estabelecer diretrizes nacionais para a gestão democrática da educação" e destacaram-se as emendas para supressão de todo o parágrafo, mas também as que solicitaram a alteração do prazo de dois anos previsto para a aprovação para imediato, e outra para um ano. 
No último parágrafo (381), deste eixo, sobre os mecanismos para promover a gestão democrática no sistema de ensino, o texto estava muito restrito às normatizações da própria LDB, dessa forma, as ementas propunham incluir também "movimentos sociais" ao conjunto com os demais segmentos elencados para a participação: "profissionais da educação, familiares, estudantes e comunidade local". Aos mecanismos previstos no texto base (descritos na citação abaixo), dez propostas de parágrafos novos foram apresentadas:

I) na elaboração ou adequação e implementação dos planos de educação;

II) no apoio e incentivo às instituições educacionais para a construção de projetos político-pedagógicos ou planos de desenvolvimento institucional sintonizados com a realidade e as necessidades locais;

III) na promoção e efetivação da autonomia pedagógica, administrativa e financeira) das instituições da educação básica, profissional, tecnológica e superior (BRASIL, 2013, p. 72).

Entre as emendas aditivas de parágrafo novo destacam-se as que tratam sobre a escolha dos dirigentes das instituições, associações de pais, professores e funcionários, papel fiscalizador dos conselhos com relação aos recursos públicos. Sobre a eleição dos dirigentes:

347 - Texto a Adicionar: Regulamentar, através de lei, a eleição direta para dirigentes das instituições de ensino superior públicas com garantia de paridade de votos entre docentes, técnico-administrativos e estudantes;

348 - Texto a Adicionar: Garantir a eleição dos dirigentes das escolas estaduais e municipais e do Distrito Federal pela comunidade, observando-se a legislação para sua nomeação;

353- Texto a Adicionar: Criar e garantir no prazo de dois anos, a escolha dos gestores das instituições públicas através do voto direto; (PARANÁ, 2013, p. 192).

Inclusão de Associação de Pais, Mestres, Funcionários (APMF) como mecanismo de participação:

349- Texto a Adicionar: Estimular a constituição e fortalecimento de associações de pais e mestres e delegar a esse órgão, autonomia a seus membros, no que diz respeito à função da associação, desde que respeitada as Leis vigentes da Instituição de Ensino, para que possam auxiliar a instituição escolar e a comunidade, na busca de soluções para as situações cotidianas em que a escola na pessoa do gestor, pais e sua equipe pedagógica achar necessário (PARANÁ, 2013, p. 192).

Sobre a composição e atribuições dos conselhos estaduais e municipais de educação na fiscalização dos recursos públicos foram apresentadas as seguintes sugestões de inclusão:

350- Texto a Adicionar: Garantir a constituição democrática dos conselhos estaduais e municipais de educação, contemplando a representação da educação básica, das instituições estaduais de ensino superior, dos trabalhadores da educação e das secretarias de estado, as quais compete a gestão da educação, da ciência, da tecnologia e do ensino superior nos estados e no Distrito Federal.";

351- Texto a Adicionar: Criar mecanismos de Controle Social para acompanhar a destinação dos recursos públicos (Bolsas, PROUNI) para instituições privadas.;

354 - Texto a Adicionar: Garantir o papel fiscalizador dos Conselhos Estaduais e Municipais de Educação no monitoramento das aplicações e prestações de contas dos recursos de ordem federal, estadual e municipal, referentes a fundos, programas e projetos, considerando sua composição e suas atribuições legais;

355 - Texto a Adicionar: Tornar público, por meio de audiências públicas e portais eletrônicos de transparência, especialmente criados para este fim, a organização, o financiamento e as ações de conselhos e de fóruns de educação, no prazo de cinco anos após aprovação do projeto de lei 8035/2010;

356- Texto a Adicionar: Assegurar nas diretrizes orçamentárias em todos os níveis de governo, recursos para capacitação e participação de todos os segmentos dos conselhos contribuídos (PARANÁ, 2013, p. 202).

Uma perspectiva democrática de organização e gestão da educação prescinde de fortalecimento dos mecanismos de participação popular e de controle social, não somente nas instituições escolares, mas fundamentalmente na gestão dos sistemas de ensino municipal, estadual e federal, enfoque este pouco discutido nas emendas deste eixo. Para tanto, reforça-se a necessidade de aprovação de normatização nacional que regulamente a gestão democrática. 


\section{Ressalva ao setor "público" na gestão da educação e dos seus recursos}

Destacam-se no conjunto de emendas deste eixo várias proposições de adjetivar a expressão "público" na gestão da educação e de seus recursos em diferentes contextos. No parágrafo 356, na seguinte frase: "Na perspectiva democrática, a educação e as instituições educacionais 'públicas' passariam a considerar a horizontalidade nas relações de poder" (grifos das autoras). No parágrafo 359 emenda aditiva após a expressão "política nacional de educação" incluindo "pública".

No parágrafo 371 destaca-se a sugestão de suprimir a expressão "privada" no final, o que limitaria a proposição somente às instituições públicas: "criar condições objetivas para o fortalecimento dos conselhos superiores das instituições de ensino superior públicas e privadas" (BRASIL, 2013, p. 71).

Sete propostas de emenda ao parágrafo 373 solicitaram que a autonomia pedagógica, administrativa e de gestão financeira das instituições educativas ficasse restrita ao "público". No parágrafo 376 que abordava a constituição e o fortalecimento de grêmio estudantil e de associação de pais e mestres também houve uma emenda adjetivando no final o "público" para funcionamento destas instituições.

Essas propostas denotam a retomada da discussão da restrição da gestão democrática às instituições públicas, debate vitorioso na Constituinte de 1987-1988. O texto final da Constituição Federal de 1988, ao art. 208, inciso VI, acrescentou-se o adjetivo "público" à gestão democrática, conteúdo este apoiado pelos setores conservadores (ADRIÃO, CAMARGO, 2001), excluindo a gestão democrática ao ensino privado.

No parágrafo 361 constava a inclusão da expressão "público" em "fortalecer os mecanismos e os instrumentos que assegurem a transparência e o controle social na utilização dos recursos públicos aplicados em educação 'pública'", assim como outra proposição de incluir "preferencialmente em instituições de educação pública" (PARANÁ, 2013, p. 183). No parágrafo 379 também constavam proposições para adjetivar educação "pública" no financiamento da educação: "constituir fóruns paritários e regulares, envolvendo gestores públicos, trabalhadores de educação e organizações da sociedade civil, para debater o financiamento da educação 'pública'” (p. 201).

Considerando a previsão legal de repasse de recursos públicos para instituições privadas prevista na Constituição Federal, essas sugestões podem ter o sentido de restrição do monitoramento da aplicação dos recursos públicos nas instituições privadas. Todavia, podem-se compreender essas emendas também no sentido de reforçar o papel do atendimento das políticas do Estado exclusivamente para o setor público.

\section{Alternância nos postos de gestão das instituições escolares}

Três das emendas do parágrafo 356 tratavam sobre a "alternância nos postos de comando e das funções a serem desempenhadas". Uma propunha adicionar a regulamentação da alternância a ser definida em lei posterior, e outras duas acrescentar a eleição direta pela comunidade para diretores de instituições educacionais públicas. Cabe destacar que a alternância foi um dos temas mais reforçados pelos presentes na conferência estadual, dado que a rede estadual e muitas redes municipais no Paraná já realizam eleição para diretores, no entanto a falta de previsão expressa da alternância ou constantes alterações nas regulamentações deste processo permite que muitos profissionais se mantenham no poder, apenas trocando de funções na composição da chapa, ora de diretor ou de vice-diretor.

Ainda sobre a instituição de eleições para diretor, destaca-se a solicitação de acrescentar ao parágrafo 375 a expressão: "garantir a escolha dos gestores escolares, pela comunidade escolar, por meio de eleição direta".

\section{Autonomia da escola na gestão dos recursos financeiros}

No parágrafo 362 que trata da transferência de recursos financeiros à escola entre as emendas que propõem modificações, destacam-se as aditivas sobre a autonomia da escola para destinar os recursos onde for necessário e estabelecimento de norma federal, com critérios simplificados na utilização e prestação de contas dos recursos. Por outro lado, uma emenda propôs retirar o final do parágrafo que estabelecia a finalidade do 
repasse dos recursos às instituições "visando à ampliação da transparência e ao efetivo desenvolvimento da gestão democrática", o que pode denotar um entendimento restrito do repasse de recursos, ou seja, da não compreensão da autonomia financeira como elemento deste princípio (PARANÁ, 2013, p.185).

No mesmo parágrafo 362, sobre a participação da comunidade escolar no planejamento e na aplicação dos recursos, uma emenda propôs sobre a compreensão de "comunidade escolar", reforçando a necessidade da presença de diferentes atores: "professores, funcionários de apoio e técnico administrativo, estudantes, pais e ou responsáveis e comunidade local" (p. 185).

\section{Considerações finais}

As emendas apresentadas nas conferências municipais e intermunicipais paranaenses indicam que ainda estamos instituindo e aperfeiçoando mecanismos que permitam o cumprimento dos critérios de uma democracia liberal no interior dos sistemas de ensino e das unidades escolares.

As indicações sobre quem devem ser os representados pela nominação dos sujeitos - movimentos sociais, funcionários, estudantes etc. - aponta para a não consolidação do critério da inclusão de todos nos processos decisórios. O que se entende por "comunidade escolar" parece estar ainda em definição.

Nas emendas nota-se forte reivindicação por paridade, ou seja, iguais condições de fazer-se representar, manifestar posições e decidir pelo voto. Percebe-se também recorrente preocupação com o provimento de condições prévias ao atendimento dos critérios quando o Documento Referência da Conae 2014 aponta necessidade de capacitação para conselheiros, apoio técnico e financeiro. A formação segue o princípio do entendimento esclarecido (DAHL, 2001), ou seja, da aquisição de compreensão dos processos e conteúdos do que é definido.

A alternância no poder apresenta-se como um aperfeiçoamento da escolha de dirigentes pelo mecanismo de eleição cuja realização iniciou-se, no Paraná, na década de 1980.

Além dessas, duas questões merecem destaque: a do financiamento e da relação público privado. Ambas estão relacionadas, como se pode ver no Documento Referência (BRASIL, 2013).

A tomada de decisão tem como objeto a realização de programas e ações no interior do espaço escolar que não se efetivam na ausência de recursos financeiros que os viabilizem. Tendo em vista a disputa sobre o fundo público, a gestão só é democrática se recair sobre questões efetivas de fazer uma escola com condições de qualidade para todos, o que implica participação nas decisões e controle na execução dos fins e dos meios para que o direito à educação se efetive.

A história das políticas educacionais no Brasil é marcada pela transferência de recursos públicos para o setor privado de ensino. Embora pontualmente os representantes desse setor tenham exercido pressões ocasionais sobre questões de currículo, faixa etária etc., é no que diz respeito ao financiamento que se centram os seus principais interesses.

A presença numericamente superior da representação do setor público nas conferências explica a preocupação com a inclusão do termo "público" e seus efeitos ambíguos no texto.

Entretanto, tal ambiguidade tem raízes para além do texto. Assenta-se na afirmação do dever do Estado no provimento da educação e da sua não realização que se faz pela ausência desse Estado, o que leva a ocupação do espaço de oferta pelo setor privado; e pela promiscuidade entre público e privado, em que o setor privado se mantém e se desenvolve por meio da transferência de recursos públicos.

Seu resultado é a manutenção de altos índices de desigualdade nas condições de qualidade e nos resultados educacionais que se põem tanto como limites quanto como desafios ao processo de aperfeiçoamento da democratização da gestão educacional e escolar.

Desse modo, a discussão do Documento Referência da Conae 2014 em conferências municipais e estaduais é expressão do movimento de conquista de um sentido de democracia que ultrapasse as definições legais, as lacunas normativas e os acúmulos históricos de desigualdade e autoritarismo. 


\section{Referências}

ADRIÃO, T.; CAMARGO, R. B. A gestão democrática na Constituição Federal de 1988. In: OLIVEIRA, Romualdo Portela de; ADRIÃO, T, (Org.). Gestão, financiamento e direito à educação: análise da LDB e da Constituição Federal. São Paulo: Xamã, 2001.

BRASIL. Constituição da República Federativa do Brasil de 1988. 1988. Disponível em: http://www.planalto. gov.br/ccivil 03/constituicao/constituicao.htm. Acesso em: 25 jun. 2014.

Lei $\mathbf{n}^{\circ}$ 8.096, de 13 de julho de 1990. Dispõe sobre o Estatuto da Criança e do Adolescente e dá outras providências. Disponível em: http://www.planalto.gov.br/ccivil 03/leis/18069.htm. Acesso em: 25 jun. 2014.

Lei 9.394, de 20 de dezembro de 1996. Estabelece as diretrizes e bases da educação nacional. Disponível em: http://www.planalto.gov.br/ccivil 03/leis/19394.htm. Acesso em: 25 jun. 2014.

Ministério da Educação. Fórum Nacional de Educação. Conae 2014: Documento Referência. Brasília: Ministério da Educação, Secretaria Executiva Adjunta, 2013. Disponível em: http://conae2014.mec.gov.br/ images/pdf/doc referencia.pdf. Acesso em: 25 jun. 2014.

COMPARATO, F.K.. Ensaio sobre o juízo de constitucionalidade de políticas públicas. Revista de Informação Legislativa. Brasília, ano 35, n. 138, abr.jun. 1998. p. 39-48.

DAHL, R. A. Sobre a democracia. Brasília: Editora Universidade de Brasília, 2001.

PARANÁ. Fórum Estadual de Educação. Caderno de Emendas Paraná ao Documento Referência da II Conae. Disponível em: http://www.app.com.br/portalapp/imprensa/Caderno Emendas Conae PR press.pdf. Acesso em: 25 jun. 2014.

PARO, V. H.. O princípio da gestão democrática no contexto da LDB. In: OLIVEIRA, Romualdo Portela de; ADRIÃO, Theresa (Org.). Gestão, financiamento e direito à educação: análise da LDB e da Constituição Federal. São Paulo: Xamã, 2001.

SILVA, J. A. Curso de Direito Constitucional Positivo. 19 ed. São Paulo: Malheiros Editores, 2001. 


\title{
Em tempos de valorização dos profissionais da educação ${ }^{1}$
}

\author{
Education professional's times of appreciation
}

\author{
En tiempos de apreciación de los professionales de la educación
}

\section{Maria Dilnéia Espíndola Fernandes ${ }^{2}$}

\section{Resumo}

Este artigo discute a questão da valorização dos profissionais da educação, diante dos seus objetivos e finalidades, no contexto atual da política educacional brasileira. Apresentando uma reflexão sobre tal conjuntura, o trabalho destaca as políticas educacionais cujo desenho institucional, no período de 1996 a 2011, materializou mecanismos importantes no âmbito da valorização docente, particularmente as políticas de fundos e o Piso Salarial Profissional Salarial (PSPN). Nas conclusões, o texto evidencia que o grande desafio para a valorização docente ainda permanece no Brasil, uma vez que o PSPN tem provocado, na conjuntura nacional, todos os estremecimentos possíveis, como o cálculo de seu reajuste ano a ano.

Palavras-chave: Valorização dos profissionais da educação; Trabalho docente; PSPN.

\begin{abstract}
:
This article discusses the question about the appreciation of education professionals face its goals and objectives in the current context of Brazilian educational policy. Featuring a reflection about this conjuncture, the study highlights the education policies whose institutional design, from 1996 to 2011, materialized important mechanisms in the area of teacher appreciation, particularly the fund policies and the National Educational Professional Minimun Wage (PSPN). In the conclusions, the text shows that the great challenge for teacher appreciation remains in Brazil, since the PSPN has led, in the national situation, all possible conflicts, such as the evaluation of its annual adjustment.
\end{abstract}

Keywords: Education Professional's appreciation; Teacher work; PSPN.

\section{Resumen:}

Este artículo aborda la questión de la apreciación de los profesionales de la educación, considerando sus metas y objetivos en el contexto actual de la política educativa brasileña. Con una reflexión sobre esta coyuntura, el estudio se centra en las políticas de educación cuyo diseño institucional, de 1996 a 2011,

10 trabalho integra a pesquisa nacional em rede: "Remuneração de Professores de Escolas Públicas de Educação Básica no contexto do Fundeb e do PSPN" financiada pelo Edital n. 049/2012, CAPES/INEP/MEC, Programa Observatório da Educação, coordenada nacionalmente pelos Professores Marcos Edgar Bassi (UFPR), Rosana Maria Gemaque Rolim (UFPA) e Maria Dilnéia Espíndola Fernandes (UFMS).

2 Doutora em Educação pela Universidade Estadual de Campinas. Professora e pesquisadora do Programa de Pós-Graduação em Educação da Universidade Federal de Mato Grosso do Sul (PPGEdu/UFMS). Coordenadora do Grupo de Trabalho Estado e Política Educacional da Associação Nacional de Pós-Graduação e Pesquisa em Educação (GT 5 - ANPEd) na gestão 2013 a 2015. E-mail: mdilneia@uol.com.br. 
materializó mecanismos importantes en el área de apreciación del profesor, en especial las políticas de fondos y el Piso Salarial Profesional Nacional (PSPN). En las conclusiones, el texto muestra que el gran desafío para la apreciación del profesor permanece en Brasil, ya que el PSPN ha generado, en la situación nacional, todos los estremecimientos posibles, como la evaluación anual de su ajuste.

Palabras-clave: Apreciación de los professionales de la educación; Trabajo Docente; PSPN.

\section{Introdução}

O propósito do trabalho é apresentar e discutir a valorização dos profissionais da educação ${ }^{3}$ - uma ideia secular -, em face dos seus objetivos e finalidades, no atual desenho das políticas educacionais.

De fato, tem-se como objetivo, no campo da política educacional, que a formação dos profissionais da educação - cada vez mais uma força de trabalho especializada - seja propulsora de sua valorização, à medida que a formação condensa esforços institucionais e individuais e tem como corolário a remuneração e a carreira no âmbito de Planos de Cargos, Carreira e Remuneração (PCCR).

A esse propósito, Souza e Gouveia (2011, p. 06) analisam:

Tem havido, seja por pressão dos movimentos sociais, seja por proposição das reformas educacionais, uma significativa alteração no perfil docente no que tange à maior formação. Isto tem relação tanto com as exigências legais, quanto ao necessário aperfeiçoamento e qualificação profissional, quanto com os (re)desenhos dos planos de carreira docente que, em alguma proporção, incorporam elementos como aumento no nível de formação para progressão e melhor remuneração na carreira. Destaca-se, em particular, o crescimento do número de profissionais que informou possuir algum curso de pós-graduação, grupo este que atinge perto de $50 \%$ em 2007, sendo que em 1997 eram apenas 12,4\%.

Nesse panorama, o Censo Educacional produzido pelo Instituto Nacional de Estudos e Pesquisas Educacionais "Anísio Teixeira" (INEP) informou que, em 30 de maio de 2007, havia 53.028.928 matrículas na educação básica brasileira, em todas as etapas e modalidades de ensino (BRASIL, 2007a). Para atender a esse contingente de matrículas, o censo levantou que 2.221.921 professores ${ }^{4}$ atuaram na educação básica em 2007 (BRASIL, 2007b). O Censo Educacional do INEP relacionou, em 2013, 2.148.023 funções docentes ${ }^{5}$ e um total de 50.042.448 matrículas na educação básica (BRASIL, 2013a). Esses valores indicam uma queda tanto no número de matrículas quanto no número de professores e ainda nas funções docentes porque, embora esta última signifique o registro do mesmo professor ocupando mais de uma função docente, justamente tal definição poderia elevar o quantitativo. Por esses dados, vê-se que as matrículas na educação básica diminuíram de 2007 a 2013 na ordem de 5,6\%. Já no caso do número de professores ou de funções docentes, mesmo que os números absolutos mostrem diminuição, não se pode precisar em números relativos, devido à base diferencial de contagem.

Pode-se argumentar que a diminuição de matrículas na educação básica tem ocorrido em larga medida pela implantação de programas de correção de fluxo, principalmente no ensino fundamental (SOUZA; GOUVEIA, 2011), por um lado e, por outro, pelo crescimento vegetativo da população brasileira (BRASIL, 2006a).

Nesse cenário, evidencia-se também que:

[...] a taxa de escolarização das crianças de sete aos 14 anos atingiu quase a universalização com atendimento de $97 \%$, [e] quanto maior o nível de rendimento familiar per capita, maior a taxa de escolarização de quatro a seis anos de idade; cerca de 80\% das pessoas de

3 Tanto a literatura especializada da área quanto a legislação educacional ora denominam "profissionais da educação" todos os trabalhadores desse setor, ora denominam somente aqueles que estão no efetivo exercício de docência e/ou cargos, funções de administração, coordenação e supervisão educacional.

40 Censo Educacional de 2007 inventariou o número de professores e não o número de funções docentes, como era habitual até então.

5 A função docente pode contabilizar um professor exercendo mais de um cargo na mesma função de professor. Isso significa que o mesmo professor pode ser contado mais de uma vez. 
15 a 17 anos estudam e apenas pouco mais de 30\% das 18 a 24 anos, sendo que, destes $71 \%$ ainda estavam no ensino fundamental ou médio; a defasagem idade-série continua sendo um dos grandes problemas da educação básica; é baixa a média de anos de estudos da população brasileira que gira em torno de seis anos de escolarização; em 2005, a taxa de escolarização líquida no ensino médio era de 45,3\% (BRASIL, 2010, p. 64-65).

Pinto e Alves ampliam a análise, ao demonstrarem a necessidade de expansão de matrículas na educação básica para a sua universalização:

Para universalizar a educação básica para a população compreendida na faixa etária de quatro a 17 anos estima-se um adicional de 3,96 milhões de alunos em todo o país. Os esforços devem ser maiores nas etapas e idades que estavam fora da faixa etária do ensino obrigatório anterior e por isso o esforço da educação infantil será maior (37,4\%), seguido pelo ensino médio (18,9\%) e 0 ensino fundamental (2,6\%). As idades que estavam fora da faixa etária obrigatória correspondem a quase $81 \%$ das matrículas a expandir ou 3,2 milhões de matrículas (PINTO; ALVES, 2011, p. 213).

Perante tal diagnóstico da educação básica brasileira, a atenção da política educacional para a valorização da docência, que se expressa na legislação em programas e atividades governamentais, tem ainda que levar em consideração a descentralização dos sistemas de ensino em uma república federativa, quando as unidades subnacionais operam em regime de interdependência e autonomia em relação à União. Decorrente disso, "[...] a organização político-administrativa da Educação no Brasil combina três diretrizes centrais: autonomia dos sistemas de ensino, organização desses sistemas em regime de colaboração e cooperação intergovernamental na educação" (FARENZENA, 2014, p. 41).

Tal organização, legada por processo histórico e consagrada pela Constituição Federal de 1988 (BRASIL, 1988), permitiu que muitas unidades subnacionais construíssem processos de descentralização de oferta da educação básica, ainda antes da aprovação da Emenda Constitucional n. 14/1996 e da Lei n. 9.394/1996 (BRASIL, 1996a; 1996b), que instituiu as Diretrizes e Bases da Educação Nacional (LDB). A descentralização verificou-se principalmente no ensino fundamental, quando os estados delegaram a seus municípios o seu atendimento, com a perspectiva de "[...] os estados contribuírem para assegurar o ensino fundamental sem a necessidade de ofertá-lo" (FARENZENA, 2014, p.42).

Como bem observou Farenzena (2014, p. 43):

Nesse processo enredou-se uma série de situações e projeções, cabendo realçar a crise fiscal dos estados e concepções ou propostas de descentralização intergovernamental, de administração pública e de repartição de encargos entre as esferas federativas nas políticas sociais, eivadas em lógicas distintas.

Não obstante, a partir dos anos 1990, no contexto da reforma administrativa do Estado brasileiro, a União centralizou a política educacional mediante reformas no currículo, na avaliação e no financiamento da educação (PERONI; OLVEIRA; FERNANDES, 2009), situação que implicou, obviamente, alterações importantes para as políticas de valorização da docência.

Nessa conjuntura, fortalece-se a tendência de centralizar as políticas educacionais pela União e descentralizar a operação e os custos para as unidades subnacionais. Tais políticas desenham-se, então, aos entes federativos, seja por forma de adesão, por indução, por adesão/induzida ${ }^{6}$ ou, ainda, com vistas à complementação financeira da União, como requer o caráter supletivo e complementar para a matéria, diante do regime de colaboração instituído pelo pacto federativo historicamente construído em solo nacional.

Assim, este trabalho destaca as políticas educacionais cujo desenho institucional, no período de 1996 a 2011, materializou mecanismos importantes no âmbito da valorização docente, a saber: as políticas de fundos e o Piso Salarial Profissional Salarial (PSPN).

6 A adesão/induzida refere-se àquelas iniciativas propostas tanto pela União quanto pelos estados, que chegam aos municípios atrelados a processos, principalmente no âmbito do financiamento. Os municípios acabam por entender que, se não aderirem, serão prejudicados, seja na esfera institucional, seja no campo do financiamento. Tal relação também se reproduz entre a União e os estados da federação. Nos anos 1990, um exemplo típico desse processo foi o programa Fundo de Fortalecimento da Escola (FUNDESCOLA) e, a partir dos anos 2000, o Programa de Ações Articuladas (PAR). 


\section{O perfil da política educacional para a valorização docente no contexto do Estado hodierno}

\section{a. O Fundef e o valor do custo/aluno/ano/mínimo: implicações para a valorização docente}

O Fundo de Manutenção e Desenvolvimento do Ensino Fundamental e de Valorização do Magistério (Fundef), instituído pela Emenda Constitucional n. 14/1996 e regulamentado pela Lei n. 9.424/1996 (BRASIL, 1996a; 1996c), surgiu no contexto da reforma administrativa do Estado brasileiro, com vistas ao ajuste estrutural no âmbito da concepção do Estado neoliberal. Por isso mesmo, o Fundef colocou em cena uma das diretrizes centrais dessa concepção de Estado, qual seja, a focalização da política social por meio de seu financiamento - neste caso, da política educacional - ao considerar como imperativo, por meio do fundo, o financiamento do ensino fundamental somente.

Destaca-se que o Fundef, ao reservar $60 \%$ dos seus recursos para salários docentes do ensino fundamental, regulou de forma centralizada por parte da União - pela primeira vez na história da educação brasileira - a obrigatoriedade para as unidades subnacionais da construção de PCCRs, com vistas à carreira e à remuneração docente.

É certo que o Fundef, ao regulamentar percentual mínimo de recursos para salários docentes, expressou também o rompimento de um acordo entre partes - entre o governo federal e a Confederação Nacional dos Trabalhadores em Educação (CNTE) -, que havia sido construído no âmbito do Plano Decenal de Educação (PDE). No contexto do PDE, acordou-se que haveria um Piso Profissional Salarial Nacional (PSPN). Isso foi rompido em 1995, quando assumiu a Presidência da República Fernando Henrique Cardoso e, no lugar do (PSPN), praticou-se o custo/aluno/ano/mínimo (FERNANDES; RODRIGUEZ, 2011).

Por sorte, a implantação do valor custo/aluno/ano/mínimo significou para professores, principalmente da esfera municipal nas regiões norte e nordeste do país, incremento salarial. Tal incremento, contudo, deveuse porque esses professores recebiam salários abaixo do salário mínimo nacional, por um lado e, por outro, porque a equação montada em torno do valor do custo/aluno/ano mínimo considerou a receita disponível para manutenção e desenvolvimento do ensino (MDE), dividida pelas matrículas do ensino fundamental registradas no censo educacional do ano anterior. Assim, paradoxalmente:

A remuneração do magistério público brasileiro, que, historicamente, já onerava mais de $60 \%$ dos recursos da educação em pagamento de pessoal, em qualquer de suas esferas, dificilmente seria aumentada significativamente pós-Fundef, a não ser em cidades e regiões em que gastasse muito pouco, e, provavelmente, de forma ilegal, em salários. [...] com relação à melhoria dos salários, as estimativas apresentadas pelo no Balanço MEC explicitam o que já se previa e esperava, ou seja, poderá haver aumento nas regiões e/ou cidades em que os salários são extremamente baixos (a maioria relacionada a um salário abaixo ou igual ao salário mínimo atual [...]) sem tradição de investimento em formação continuada ou cumprimento de qualquer carreira ou estatuto do magistério (ARELARO, 1999, p. 34-35).

Outra implicação importante para a valorização docente no contexto do Fundef foi que, até o final dos anos 1990, muitos municípios, pelo país afora, apesar da obrigatoriedade da lei, não tinham aprovado os PCCRs (GATTI; BARRETO, 2009).

Tal desenho da política educacional, que se tornou a força motriz para a valorização docente por meio da carreira e remuneração no contexto da reforma administrativa do Estado brasileiro, operou positivamente, consoante à reforma engendrada.

De fato, o Fundef expressou, no campo da política educacional, as diretrizes da reforma do Estado de contenção de receitas e de custos. Por um lado, desobrigou a União de gastar em MDE volumes significativos de recursos na "[...] aplicação direta de recursos na erradicação do analfabetismo" (DUARTE; TEIXEIRA, 1999, p. 05); por outro, redistribuiu os recursos existentes - aqueles oriundos do artigo 212 da Constituição Federal de 1988 - por meio de transferências entre as unidades subnacionais. Tal operação contábil provocou nova organização para as receitas e despesas com MDE. Contudo, isso nem sempre se expressou na valorização docente por meio dos PCCRs. 


\section{b. O Fundeb e o PSPN: implicações para a valorização docente}

O Fundo de Manutenção e Desenvolvimento da Educação Básica e de Valorização dos Profissionais da Educação (Fundeb) foi instituído pela Emenda Constitucional n. 53/2006 e regulamentado pela Lei n. 11.494/2007 (BRASIL, 2006b; 2007c). A Lei n. 11.494/2007 dispôs em seu artigo 41: "O poder público deverá fixar, em lei específica, até 31 de agosto de 2007, piso salarial profissional nacional para os profissionais do magistério público da educação básica" (BRASIL, 2007c). Tal dispositivo ensejou a aprovação da Lei n. 11.738, em agosto de 2008, que instituiu o Piso Salarial Nacional Profissional para os profissionais da educação básica (BRASIL, 2008a).

De fato, a partir da gestão governamental de Lula da Silva na Presidência da República, houve a expectativa de que um novo fundo viesse a substituir o Fundef. Tal expectativa de substituição girou em torno das críticas que o Fundef havia recebido durante a sua vigência, por vários atores coletivos, e também pelos compromissos firmados entre Lula da Silva com setores organizados da sociedade civil durante o processo da campanha eleitoral.

Não obstante a conjuntura econômica e política nacional estivesse estremecida por "[...] oito anos de reformas liberais, [quando] o Estado aparece, uma vez mais, fraco, desarticulado e com baixa capacidade de iniciativa estratégica" (FIORI, 2003, p. 196), em tal saldo conjuntural, entre outras situações, para esse autor,

[...] a grande novidade é a vitória de um partido de esquerda, com um projeto popular e nacional de democratização do desenvolvimento: uma novidade histórica, em todos os sentidos. A viabilidade de projeto dependerá da sua capacidade de mobilizar o povo e construir uma vontade nacional, obrigando as elites a se voltarem para sua própria terra e sua gente (FIORI, 2003, p. 196-197).

Sob essa perspectiva, iniciou-se ainda em 1995 a construção do processo de substituição do Fundef pelo Fundeb. Oliveira (2009, p. 52) denominou esse caminho de "percursos legislativos". Contudo, sua "[...] proposição ocorre tardiamente em relação às expectativas geradas pelos compromissos firmados ainda em campanha eleitoral pelo então Presidente Luis Inácio Lula da Silva" (OLIVEIRA, 2009, p. 54).

De fato, a expectativa era de que, também, a concepção de Estado neoliberal, posta em marcha desde 1989, fosse revista e que as políticas educacionais espelhassem tal revisão. O Fundeb trouxe elementos que puderam ser aventados como pressupostos de redefinição do papel do Estado, principalmente ao resgatar o conceito de educação básica pelo fundo. Também o Fundeb expressou vínculos de "[...] regras constitucionais, legado de políticas prévias e o ciclo da política [que estrutura] arenas decisórias, [...] fundamental para compreender o sucesso ou o fracasso de dada política pública" (ARAÚJO, 2011, p. 3).

Paradoxalmente, o Fundeb não conseguiu atingir um ponto crucial, qual seja: "Os obstáculos econômicos - a histórica resistência à manutenção da educação pública no Brasil” (SAVIANI, 2009, p. 16). Isso porque o Fundeb não enfrentou o aumento de receitas para MDE, além dos dispostos na vinculação constitucional de recursos. É verdade que, nas transferências intrarredes, pode haver aumentos de recursos - como também podem ocorrer perdas -, dado que o fundo é estadual. Entretanto, a operação contábil não eleva o patamar de receitas além da vinculação constitucional. Nesse panorama, permaneceram os obstáculos para a valorização dos profissionais da educação, que se explicitaram com maior intensidade a partir da aprovação da Lei n. 11.738/2008 (BRASIL, 2008a).

A aprovação desta lei colocou a valorização dos profissionais da educação no centro da agenda da política educacional, sobretudo pela descentralização do sistema educacional. Afinal, pagam os salários docentes da educação básica, estados e municípios. Assim, se a lei centralizou sob o comando da União um PSPN, descentralizou seus custos para as unidades subnacionais. Obviamente, permaneceu na lei em questão o caráter supletivo e complementar da União para as unidades subnacionais cuja receita fosse insuficiente para alcançar o Piso.

O fato foi que a aprovação da lei que institui o PSPN provocou estremecimentos na conjuntura política entre as unidades federativas. Alegaram os estados, ao acionar o Poder Judiciário, por meio de uma Ação Direta de 
Inconstitucionalidade (ADin) ${ }^{7}$, quebra pela União da autonomia federativa. Porque, na avaliação dos estados, a União estaria legislando em esfera não própria de sua atuação ao instituir, pela Lei n. 11.738/2008 (BRASIL, 2008a), além de um Piso Nacional, as horas atividades dos professores dedicadas a estudos e planejamento de trabalho, cuja conta as unidades subnacionais teriam que pagar.

A questão política que se transformou em contenda judicial foi resolvida pelo Supremo Tribunal Federal (BRASIL, 2008b) em favor da União. Tal decisão, entretanto, não significou a imediata valorização docente pela aplicação do PSPN no escopo de carreira, remuneração e jornada de trabalho. Desde a aprovação da lei, a Confederação Nacional dos Trabalhadores em Educação (CNTE) tem construído mobilizações de professores em todo o país, com o objetivo de que a lei que instituiu o PSPN seja cumprida por estados e municípios. Diante disso, a CNTE informou que, em 2013:

[...] não pagam o piso os estados de Alagoas, Amazonas, Bahia, Maranhão, Paraná, Piauí, Rio Grande do Sul, Rondônia. Não cumprem a lei na íntegra: Amapá, Espírito Santo, Goiás, Mato Grosso, Mato Grosso do Sul, Minas Gerais, Pará, Paraíba, Rio Grande do Norte, Roraima, São Paulo, Santa Catarina e Sergipe. Cumprem a lei na totalidade: Acre, Ceará, Distrito Federal, Pernambuco e Tocantins. Não informado: Rio de Janeiro (CONFEDERAÇÃO NACIONAL DOS TRABALHADORES EM EDUCAÇÃO, 2013, p.01).

De fato, no âmbito da República Federativa, há que se levar em conta a "organização político-territorial do poder" (ABRUCIO, 2006, p. 95). Para o autor, o Brasil apresenta duas condições de natureza histórica em sua constituição que justificam o federalismo e que se expressam na "[...] desigualdade regional e na diversidade de formação das elites locais" (Idem, ibidem). A aprovação da Lei n. 11.738/2008 (BRASIL, 2008a) e a sua trajetória, até então, têm sido exemplares para a materialização das duas dimensões elencadas por Abrucio (2006) na experiência federativa brasileira.

A aprovação desta lei se deu no contexto de uma redefinição de concepção de Estado, quando seu novo modelo - ainda inconcluso - (POCHMANN, 2011) estaria engendrando o estado pós-neoliberal ou o estado de padrão de novo desenvolvimentismo no Brasil (OLIVA, 2010) que teria, entre suas premissas, a ampliação do padrão dos direitos sociais por meio da recuperação da política social, como instrumento de reprodução de classe. Apesar disso, a manifestação dos traços elencados por Abrucio (2006) na constituição da República Federativa Brasileira são elementos que vêm obstaculizando tal processo. De fato, confrontam-se agora, em plena vigência da Lei n. 11.738/2008 (BRASIL, 2008a), o poder local versus o poder nacional.

Nesse contexto, a observância da lei federal, como requer o modelo federativo, é interpretada pelas unidades subnacionais no plano político-ideológico como indução da União. Por sua vez, no plano fiscal-orçamentário, reportarem-se a uma lei federal, para as unidades subnacionais, seria como se a União exigisse que estados e municípios pagassem uma conta com a qual elas não poderiam arcar. Ou seja, a União interferiria em esfera que não seria de sua competência, ao aprovar uma lei cuja conta seria paga pelas unidades subnacionais. Retomouse aqui, por ocasião da aprovação da Lei n. 11.738/2008 (BRASIL, 2008a), em novas bases, a força política dos governadores, objeto de análise desenvolvida por Faoro (2012), quando se deteve em: "A transição para o federalismo hegemônico: a política dos governadores" (FAORO, 2012, p. 626). Mais recentemente, Abrucio (2002) atentou-se para o poder dos governadores na federação brasileira:

Os estados [...] constituíram-se em obstáculos ao processo de descentralização, o que não quer dizer que eles não tenham aumentado sua atuação e seus gastos nas políticas públicas. 0 fato é que a descentralização das políticas ocorreu segundo as conveniências políticas de cada governo estadual. Esta atomização, como a vista no caso da guerra fiscal, tem reflexos verdadeiramente predatórios para o conjunto da Federação (ABRUCI0, 2002, p. 196-197).

Mais um protagonista apresentou-se nessa conjuntura, para reforçar o poder local diante da aprovação e implementação da Lei n. 11.738/2008 (BRASIL, 2008a) e do que isso representaria - de forma negativa - no

7 Os governadores impetrantes da ADIn n. 4.167, de 28 de outubro de 2008, foram os dos estados do Rio Grande do Sul, Santa Catarina, Paraná, Mato Grosso do Sul e Ceará. Contaram com o apoio dos governadores dos estados de São Paulo, Minas Gerais, Tocantins e do Distrito Federal (FERNANDES; RODRIGUEZ, 2001, p. 96). 
contexto das finanças municipais. Tratou-se da Confederação Nacional dos Municípios (CNM), que informou: "Os recursos do Fundeb não estão sendo suficientes para o pagamento da folha do magistério. Em 2009, 87\% dos Municípios comprometeram 75\% do Fundeb com a folha do magistério" (CONFEDERAÇÃO NACIONAL DE MUNICÍPIOS, 2011, p. 08). Cabe lembrar que a subvinculação dos recursos para MDE do Fundeb não são a totalidade de recursos que estados e municípios tem para financiar MDE, cuja rubrica inclui salários docentes. Além da subvinculação, está a vinculação constitucional de recursos da ordem de $25 \%$ da receita de impostos a ser gasta no mínimo, ao ano. Tais receitas poderiam, também, ser acrescidas de mais recursos para salários docentes e para a educação de forma geral. Nada impede a ampliação dessa conta, a depender da capacidade de inovação de cada ente federativo para recuperar/aumentar suas finanças. Isso faria jus aos discursos em campanhas eleitorais, quando a educação é sempre alçada como meta da maior importância para alavancar o desenvolvimento econômico e social de cada lugar de onde se fala. Também há, nesse tipo de argumentação produzida e fomentada pela CMN, a manifestação de traços históricos do estado patrimonialista e coronelista porque, entre outros fatores, é "[...] a fraqueza financeira dos municípios um fator que contribui, relevantemente, para manter o 'coronelismo' na sua expressão governista” (LEAL, 2012, p. 65).

A propósito, a Controladoria-Geral da União (CGU), ao exercer processo de fiscalização em uma amostra selecionada de 124 unidades subnacionais (quatro estados e 120 municípios), em 2013, arguiu: "A parcela do Fundeb destinada à remuneração dos profissionais vem contribuindo para a valorização dos mesmos e para a implantação do plano de carreira?" (BRASIL, 2013b, p. 07). O relatório em questão concluiu que:

[...] somente em 83 ocorreu 0 atingimento do limite mínimo de aplicação de 60\% dos recursos na remuneração dos professores. Observou-se, ainda, que em cinco das unidades fiscalizadas ocorreram pagamentos com mais de 30 dias de atraso. Tais dados demonstram a adoção de procedimentos inadequados quanto ao cumprimento do percentual mínimo de $60 \%$ dos recursos com a remuneração dos profissionais do magistério. [...] Foi detectada a falta de implantação do plano de carreira, integral, do magistério em 14 unidades das 124 fiscalizadas (BRASIL, 2013b, p. 07-08).

Caber pontuar que o relatório da CGU, devido à sua natureza e finalidade, registrou tal situação em unidades subnacionais que receberam complementação de recursos da União para o Fundeb. Como o próprio relatório expôs, "a Ação OE-36" objetiva "[...] a participação da União, a título de complementação, [...] de forma a garantir, no âmbito dos estados onde o valor per capita do Fundo encontrar-se abaixo do valor mínimo nacional por aluno/ano, o alcance desse valor mínimo nacional” (BRASIL, 2013b. p. 5). O relatório em questão fiscalizou a aplicação dos recursos complementares da União ao Fundeb durante os anos de 2007 a 2012 e informou:

Nesse período, dez estados das regiões Norte e Nordeste foram contemplados com recursos de complementação da União para execução do Fundeb (Alagoas, Amazonas, Bahia, Ceará, Maranhão, Pará Paraíba Pernambuco, Piauí e Rio Grande do Norte), sendo que o Estado do Amazonas iniciou em 2008 e Rio Grande Norte recebeu esses recursos a partir de 2011(BRASIL, 2013b, p. 06).

Diante disso, pode-se considerar que se tratou de amostragem pequena, dada a dimensão territorial brasileira, por um lado e, por outro, porque, dada a equação que opera os recursos do Fundeb - a subvinculação de $20 \%$ das receitas de impostos, as matrículas da educação básica registradas no censo do INEP do ano anterior e o coeficiente de ponderação para etapas e modalidades de ensino que resultam no valor do custo/aluno/ano/ mínimo -, a maioria dos entes subnacionais não necessitou de recursos complementares da União no período considerado, objeto da Ação OE-36 da Controladoria-Geral da União.

De fato, ao se estender o alcance da fiscalização, poderia se aventar a hipótese de que mais unidades subnacionais estariam negligenciando os dispositivos legais que regulam o Fundeb, ao mesmo tempo que poderiam estar também obstaculizando a valorização docente por meio de salários, ausências ou inconclusões de PCCRs.

Não obstante o fundo tenha instituído, para cada ente federativo, o Conselho de Acompanhamento e Controle Social (CACS) para o uso e a aplicação de seus recursos, a composição e a atuação dos CACS têm apresentado tanto limites como possibilidades no trato da transparência pública para o financiamento de 
MDE. Já se constatou que os CACS, desde o Fundef, têm a possibilidade de alargar as potencialidades do jogo democrático no interior de uma dada sociedade (FERNANDES; OLIVEIRA, 2011), daí sua importância e imprescindibilidade. Como também defendeu Sena (2008, p. 321), "[...] no aspecto do controle social, as fragilidades reveladas no período do Fundef levaram ao aperfeiçoamento das regras referentes aos conselhos, acerca de sua autonomia, democracia, composição e instrumentos" no Fundeb. Sobre as limitações dos CACS (DAVIES, 2006), duas ainda são recorrentes: a tentativa de o poder público em estados e municípios transformar o controle social em somente controle estatal e, por vezes, a baixa capacidade técnica dos quadros que o compõem, no que tange à matéria do financiamento da educação. Tais limites podem, sobretudo, se expressar no que concerne à valorização docente, pois uma baixa capacidade técnica de membros desse conselho tende a ser mais influenciada por dados que nem sempre correspondem à realidade.

Observa-se que, no desenho das atuais políticas educacionais que têm como objetivo e finalidade a valorização docente por meio de salários, remuneração, planos e carreiras, as contradições engendradas na dinâmica do processo social e econômico revelam-se no plano político-ideológico, com vistas à manutenção do status quo. Enfrentar pari passu tais contradições tem sido o desafio posto à força de trabalho docente organizada em suas instâncias sindicais, culturais e acadêmicas.

\section{Considerações finais}

O período longevo de construção, discussão e tramitação do recentemente aprovado Plano Nacional de Educação ${ }^{8}$ (PNE) pode representar, por um lado, o alargamento de relações democráticas no conjunto da sociedade brasileira, mas sobretudo por outro lado, pode revelar que a aprovação de um PNE está direta e proporcionalmente relacionada a um projeto de sociedade em disputa.

De fato, o novo PNE poderia se somar às demais políticas educacionais que engendrariam a valorização docente por meio de salários e PCCRs. Durante os anos de construção do PNE, as lutas de setores organizados da sociedade brasileira em defesa da escola pública referenciada na qualidade social, construíram e disputaram a perspectiva de que o PNE poderia ser o instrumento para aumentar os recursos para a educação pública além do dispositivo constitucional. Diante disso, o Fundeb, tanto quanto os demais recursos para MDE, poderiam ser acrescidos por outras fontes de financiamento para promover, por exemplo, o Custo Aluno Qualidade (CAQ), estratégia 20.5 da Meta 20 (BRASIL, 2014), que versa sobre a ampliação dos investimentos em educação no PNE.

A redação final da Meta 20 do PNE (Idem, ibid, 2014), todavia, se expressou o consenso possível, não correspondeu integralmente às expectativas daqueles que defendem a educação pública referenciada na qualidade social. Isto porque a pretensão de se ter 10\% do Produto Interno Bruto (PIB) para financiar a educação pública saiu de cena, como historicamente tem ocorrido nas peças de planejamento para o setor. Concorrerão para ter recursos públicos, nesse cenário, os setores públicos e privados. Como argumentou Saviani em entrevista à Associação Nacional de Pós-Graduação e Pesquisa em Educação (ANPEd),

[...] o empresariado assumiu o discurso da importância da educação considerada um bem de produção e passou a se manifestar e intervir mais diretamente no campo educacional influenciando as políticas e ocupando espaços nos órgãos da administração educacional como as secretarias estaduais e municipais e os Conselhos em todos os níveis (SAVIANI, 2014, p.01).

Para a constituição do CAQ, também a Meta 20 o deixa opaco, comprometido, pois a estratégia de sua construção estabeleceu: "Definir o custo aluno-qualidade da educação básica à luz da ampliação do investimento público em educação" (BRASIL, 2014). Assim, a definição do CAQ passará a ser delimitada pela disponibilidade gradativa de recursos até o percentual de $10 \%$ do PIB até 2024, que concorrerá com a iniciativa privada pelos recursos públicos.

8 Lei n. 13.005, de 26 de junho de 2014. Disponível em: http://presrepublica.jusbrasil.com.br/legislacao/125099097/lei-13005-14?ref=home. Acesso em 27 jun. 2014. 
Também se mostrou alvissareira, na atual conjuntura, a destinação de recursos do pré-sal para aumentar os recursos para a educação. Principalmente porque tal medida acrescentaria novas fontes de financiamento para a educação, além das receitas de impostos, cuja fonte é a que se tem materializado, não sem contradições e paradoxos, desde a Constituição Federal de 1988 (BRASIL, 1988). No entanto, sobre os recursos do pré-sal para as políticas setoriais, alertou Lima: "[...] apenas uma pequena parcela será destinada diretamente ao estado brasileiro. Dessa parcela, um pequeno percentual será destinado às áreas de educação e saúde" (LIMA, 2014 p. 36). Em relação à educação, as receitas do pré-sal

[...] poderão ser aplicadas no custeio de despesas com manutenção e desenvolvimento do ensino, especialmente na educação básica pública em tempo integral, inclusive as relativas a pagamento de salários e outras verbas de natureza remuneratória a profissionais do magistério em efetivo exercício na rede pública (Idem, ibid. p. 46).

Assim, no contexto regulatório atual sobre o pré-sal, cabe considerar que:

Embora a legislação sobre a questão ainda possa ser alterada, a educação poderá receber recursos da exploração de petróleo e gás natural de duas formas diferentes. Uma delas é a remuneração dos investimentos feitos por um fundo social (FS), criado pela lei 12.351 de 2010, e outra é formada pelos royalties gerados por concessões de exploração posteriores a 3 de dezembro de 2012, Lei 9.478 de 1997, ambas alteradas pela Medida Provisória 592 de 2012 (HELENE, 2013, p. 01).

A descoberta do pré-sal e consequente padrão de desenvolvimento científico e tecnológico para sua exploração e comercialização, portanto, exigiu marcos regulatórios da esfera da União que, por sua vez, vem provocando estremecimentos nas relações federativas. Tal questão, historicamente denominada de "Guerra Fiscal", é

Fruto da artificiosidade política, característica do modelo federativo, silenciosa e inerente aos estados federados trata-se de uma antiga batalha travada entre os Estados que detém autonomia gerencial sobre interesses definidos como locais, convivendo sob jurisdição de uma comum União. Com associação direta à questão tributária, é histórica a situação e se reveste de situações de embate político e social, desde o império no Brasil (SANTOS, 2013, p. 83).

Neste caso em particular, trata-se do enfrentamento, com a União, de como serão divididos os recursos oriundos do pré-sal entre as unidades estaduais produtoras e confrontantes (LIMA, 2014).

Nesse panorama conjuntural, alguns desafios para a valorização docente no campo jurídico-legal vêm sendo vencidos, como requer a construção de uma sociedade democrática. Um deles consolidou-se na transparência que as políticas de fundos ensejaram aos recursos para financiar MDE. De fato, não sem contradições, o Fundef e o Fundeb colocaram, no centro da agenda política, econômica e social, a possibilidade histórica de endereçar os recursos de MDE para as suas finalidades. Outro desafio que vem sendo configurado conjunturalmente é a implantação da Lei n. 11.738/2008 (BRASIL, 2008a), em um sistema de ensino descentralizado e que, por isso mesmo, convive com múltiplos sistemas de ensino, diante do modelo federativo historicamente construído. Os poderes locais - quando Ihes interessa - afirmam a indução centralizadora da União para se contrapor às suas regulamentações, mesmo que seja em matéria sobre a qual, a princípio, todos concordariam, como é o caso de salários e horas atividades dos professores.

Mas o grande desafio para a valorização docente, carreira, remuneração e jornada de trabalho ainda permanece. O PSPN tem provocado, na conjuntura econômica e política nacional, todos os estremecimentos possíveis, alguns já superados, outros ainda em curso, como o cálculo de seu reajuste ano a ano. De fato, o reajuste anual do PSPN deve operar com o mesmo índice de reajuste do valor do custo/aluno/ano/Fundeb. Contudo, ao se tomar aqui como exemplo o reajuste do PSPN praticado em 2013, constatou-se que: "Cálculos preliminares do governo federal apontam um aumento de 19\% em 2014, mais do que o dobro do que os 7,97\% concedidos à categoria no início deste ano. Hoje, nenhum docente pode receber menos do que R\$1.567" (FOREQUE, 2013). Mais uma vez, os protagonistas de tal restrição salarial foram os governadores estaduais, pois, "[...] com a previsão de um alto reajuste do piso nacional dos professores da educação básica, os governadores se uniram para sugerir uma nova fórmula de correção dos salários" (Idem, ibid.). Outra situação importante 
consiste em superar a problemática de que, entre os profissionais com o mesmo grau e nível de formação, os professores constituem categoria com os menores salários e que, por isso mesmo, a atratividade na carreira é cada vez menos sedutora, o que compromete a formação de futuras gerações para magistério.

A perspectiva de lidar com tal problemática, de forma a reduzir tais disparidades no contexto da valorização docente, reside novamente no recente PNE aprovado - Lei n. 13.005/2014 (BRASIL, 2014), que estabeleceu:

[...] até o sexto ano de vigência, os salários dos professores da educação básica [deverão] ser equiparado ao rendimento médio dos demais profissionais com escolaridade equivalente. [...] em dez anos, 50\% desses professores deverão ter pós-graduação. Todos deverão ter acesso à formação continuada (AQUINO, 2014, p. 01).

Trata-se de verificar, agora, como reagirão os poderes locais diante do novo dispositivo do PNE.

Por tudo isso, resoluções a esse respeito estão a depender - aliás, como sempre estiveram - do grau de organização dos professores da educação básica do Brasil - cerca de 2.148.023, distribuídos em funções docentes em 2013 - e também do grau de adesão que a categoria possa amalgamar com setores da sociedade brasileira em defesa da escola pública referenciada na qualidade social da educação.

\section{Referências}

ABRUCIO, L.F. Os barões da federação - os governadores e a redemocratização brasileira. $2^{a}$ ed. São Paulo, SP: HUCITEC, 2002, 253 p.

Para além da descentralização: os desafios da coordenação federativa no Brasil. In: FLEURY, S. (Org.). Democracia, descentralização e desenvolvimento: Brasil e Espanha. Rio de Janeiro: FGV, 2006, p. 77-125.

AQUINO, Y. EBC Agencia Brasil. Dilma sanciona Plano Nacional de Educação sem vetos. 26 de junho de 2014. Disponível em: < http://agenciabrasil.ebc.com.br/educacao/noticia/2014-06/dilma-sanciona-planonacional-de-educacao-sem-vetos >. Acesso em 27 jun. 2014.

ARAÚJO, L. O federalismo brasileiro e a aprovação da Emenda Constitucional n. 53 de 2006. Fineduca Revista de Financiamento da Educação, v. 1, n. 5, p. 1-13, 2011.

ARELARO, L.R.G. Financiamento e qualidade da educação brasileira: algumas reflexões sobre o documento "Balanço do Primeiro Ano do Fundef - Relatório MEC". In: DOURADO, L.F. (Org.). Financiamento da educação básica. Campinas, SP: Autores Associados; Goiânia, GO: UFG, 1999, p. 27-46.

BRASIL. Lei n. 9.394, de 20 de dezembro de 1996. Estabelece as diretrizes e bases da educação nacional. Diário Oficial da União, Brasília, DF: 23 dez. 1996b.

Lei n. 9.424, de 24 de dezembro de 1996. Dispõe sobre o Fundo de Manutenção e Desenvolvimento do Ensino Fundamental e de Valorização do Magistério - FUNDEF. Diário Oficial da União, Brasília, DF: 26 dez. 1996c.

Instituto Brasileiro de Geografia e Estatística. Indicadores Sociodemográficos Prospectivos para

- Brasil 1991-2030. Rio de Janeiro, out. 2006a. Disponível em: < http://www.ibge.gov.br/home/estatistica/ populacao/projecao_da_populacao/publicacao_UNFPA.pdf > . Acesso em: 29 mai. 2014.

Constituição Federal de 1988. Emenda Constitucional n. 53, de 19 de dezembro de 2006. Dá nova redação aos arts. $7^{\circ}, 23,30,206,208,211$ e 212 da Constituição Federal e ao art. 60 do Ato das Disposições Constitucionais Transitórias. Brasília, DF: 2006b. Disponível em: < http://www.planalto.gov.br/ccivil_03/ constituicao/Emendas/Emc/emc53.htm >. Acesso em: 08 jun. 2014.

Ministério da Educação. Instituto Nacional de Estudos e Pesquisas Educacionais Anísio Teixeira.

Sinopse Estatística da Educação Básica. Brasília: 2007a. Disponível em: < http://portal.inep.gov.br/basicacenso-escolar-sinopse-sinopse >. Acesso em: 29 mai. 2014.

Ministério da Educação. Instituto Nacional de Estudos e Pesquisas Educacionais Anísio Teixeira. 
Sinopse Estatística do Professor (atualizado em 29/05/2009). Brasília: 2007b. Disponível em: < http://portal. inep.gov.br/basica-censo-escolar-sinopse-sinopse >. Acesso em: 29 mai. 2014.

Lei n. 11.494, de 20 de junho de 2007. Regulamenta o Fundo de Manutenção e Desenvolvimento da Educação Básica e de Valorização dos Profissionais da Educação - Fundeb e dá outras providências. Brasília, DF: 2007c. Disponível em: <http://www.planalto. gov.br.>. Acesso em: 05 mai. 2011.

Lei n. 11.738, de 16 de julho de 2008. Regulamenta a alínea "e" do inciso III do caput do art. 60 do Ato das Disposições Constitucionais Transitórias, para instituir o piso salarial profissional nacional para os profissionais do magistério público da educação básica. Brasília, DF: 2008a. Disponível em: <http://www. planalto.gov.br>. Acesso em: 10 ago. 2010.

Supremo Tribunal Federal. Decisão Tribunal Pleno, 17 /12/ 2008. Acompanhamento Processual da ADI 4167 - Ação Direta de Inconstitucionalidade, 2008b. Disponível em: < www.stf.jus.br/portal/processo/ verProcessoAndamento.asp?numero $=4167 \&$ classe $=$ ADI\& origem $=$ AP\&recurso=0\&tipoJulgamento $=M>$. Acesso em: 3 mar. 2010.

Ministério da Educação. Conae 2010 - Conferência Nacional de Educação - construindo o Sistema Nacional Articulado de Educação: o Plano Nacional de Educação, diretrizes e estratégias de ação - Documento Final. Brasília, DF: MEC, 2010.

Ministério da Educação. Instituto Nacional de Estudos e Pesquisas Educacionais Anísio Teixeira.

Sinopses Estatísticas da Educação Básica. Brasília, DF: 2013a. Disponível em: < http://portal.inep.gov.br/ basica-censo-escolar-sinopse-sinopse >. Acesso em: 29 abr. 2014.

Controladoria-Geral da União. Secretaria Federal de Controle Interno. Relatório de avaliação da execução de programas de governo n 22 - complementação da União ao Fundo de Manutenção e Desenvolvimento da Educação Básica e de Valorização dos Profissionais da Educação - Fundeb. Brasília, DF: 2013b.

Lei n. 13.005, de 25 de junho de 2014. Aprova o Plano Nacional de Educação - PNE e dá outras providências. Disponível em: < http://www.jusbrasil.com.br/topicos/27489479/lei-n-13005-de-25-de-junhode-2014 >. Acesso em: 20 jun. 2014.

CONFEDERAÇÃO NACIONAL DE MUNICÍPIOS. Impacto da Lei do piso salarial dos profissionais do magistério público da educação básica nas finanças municipais. Estudos Técnicos. Brasília, DF: v. 2, 2009.

CONFEDERAÇÃO NACIONAL DE MUNICÍPIOS. Educação. O piso salarial nacional do magistério público em debate. Informativo CNM. Brasília, DF: 2011.

CONFEDERAÇÃO NACIONAL DOS TRABALHADORES EM EDUCAÇÃO. CNTE divulga tabela atualizada dos estados que não respeitam integralmente a Lei do Piso. Brasília, DF: 2013. Disponível em: < http://www. cnte.org.br/index.php/lutas-da-cnte/piso-salarial-e-carreira/11802-cnte-divulga-tabela-atualizada-dos-estadosque-nao-respeitam-integralmente-a-lei-do-piso.html >. Acesso em: 14 jun. 2014.

DAVIES, N. Fundeb: a redenção da educação básica? 2006. Disponível em: < http://www.scielo.br/pdf/es/ v27n96/a07v2796. pdf >. Acesso em: 21 mar. 2012.

DUARTE, M. R. T.; TEIXEIRA, V.L. Política Nacional de administração da edecação básica - autonomia e intervenção. IN: DOURADO, L.F. (Org.). Financiamento da educação básica. Campinas, SP: Autores Associados; Goiânia, GO: UFG, 1999, p. 05-25.

FAORO, R. Os donos do poder - formação do patronato político brasileiro. $5^{a}$ ed. São Paulo, SP: Globo, 2012.

FARENZENA, N. Panorama do gasto público em educação na esfera estadual. In: PINTO, J.M.R.; SOUZA, S.A. (Orgs.). Para onde vai o dinheiro? Caminhos e descaminhos do financiamento da educação. São Paulo: Xamã, 2014, p. 41-56.

FERNANDES, M.D.E.; OLIVEIRA, R.T.C. O Fundef no Estado de Mato Grosso do Sul: Balanço da Política de 
Financiamento para o Ensino Fundamental (1998 a 2006). Fineduca - revista de Financiamento da Educação, Porto Alegre, v.1, n.4, p. 01-19, 2011

FERNANDES, M.D.E.; RODRIGUEZ, M.V. O processo de elaboração da Lei n. 11.738/2008 (Lei do Piso Salarial Profissional Nacional para carreira e remuneração docente): trajetória, disputas e tensões. Histedbr Online, Campinas, n.41, p. 88-101, mar. 2011.

FOREQUE, F. Governadores se unem por reajuste menor do piso de docentes. Brasília, DF: 2013. Disponível em: < http://www1.folha.uol.com.br/educacao/2013/09/1345978-governadores-se-unem-por-reajuste-menor-dopiso-nacional-do-professor.shtml >. Acesso em: 23 set. 2013.

HELENE, O. Os recursos do Pré-Sal para a educação. 2013. Disponível em: < http://www.correiocidadania. com.br/index. php?option=com_content\&view=article\&id=8422: submanchete290513\&catid=72:imagensrolantes >. Acesso em: 21 jun. 2014.

FIORI, J.L. O voo da coruja - para reler o desenvolvimentismo brasileiro. Rio de Janeiro, RJ: Record, 2003, $207 \mathrm{p}$.

GATTI, B.A.; BARRETO, E.S.S. Professores do Brasil: impasses e desafios. Brasília, DF: UNESCO, 2009, $293 \mathrm{p}$.

LEAL, V.N. Coronelismo, enxada e voto - o município e o regime representativo no Brasil. $7^{a}$ ed. São Paulo, SP: Companhia das Letras, 2012, 363 p.

LIMA, P.C.R. Cartilha sobre o petróleo e as receitas para a educação. Versão preliminar. Brasília: [s.n.], 2014, 63 p.

OLIVA, A.M. As bases do novo desenvolvimentismo no Brasil: análise do governo Lula (2003-2010). 2010. 537 p. Tese (Doutorado) - Instituto de Economia, Universidade Estadual de Campinas. Campinas, SP.

PERONI, V.M.V.; OLIVEIRA, R.T.C.; FERNANDES, M.D.E. Estado e terceiro setor: as novas regulações entre o público e o privado na gestão da educação básica brasileira. Educação e Sociedade, Campinas, v. 30, n. 108, p. 761-778, out. 2009.

PINTO, J.M.R.; ALVES, T. O impacto financeiro da ampliação da obrigatoriedade escolar no contexto do Fundeb. Educação e Realidade, Porto alegre, v. 36, n. 2, p. 605-624, maio/ago. 2011.

POCHMANN, M. O trabalho no Brasil pós-neoliberal. Brasília, DF: Liber, 2011, 206 p.

SANTOS, G.J. A guerra fiscal e suas ligações federativas. Jornal Eletrônico. Faculdades Integradas Vianna Júnior. 2013. Disponível em: < http://www.viannajr.edu.br/files/uploads/20140226_145602.pdf >. Acesso em 21 jun. 2014.

SAVIANI, D. Sistema de Educação: subsídios para a Conferência Nacional de Educação. 2009. Disponível em: < http://conae.mec.gov.br/images/stories/pdf/conae_dermevalsaviani.pdf >. Acesso em: 27 jan. 2014.

Entrevista com Dermeval Saviani - PNE. 07 de abril de 2014. Entrevista concedida a Associação Nacional de Pós-Graduação e Pesquisa em Educação (ANPEd). Disponível em: < http://www.anped.org.br/ news/entrevista-com-dermeval-saviani-pne >. Acesso em: 20 jun. 2014.

SENA, P. A legislação do Fundeb. Cadernos de Pesquisa, v. 38, n. 134, p. 319-340, maio/ago. 2008.

SOUZA, A.R.; GOUVEIA, A.B. Os trabalhadores docentes da educação básica no Brasil em uma leitura possível das políticas educacionais. Arquivos Analíticos de Políticas Educativas. Arizona, EUA, v. 19, n. 35, p. 01-22, jan. 2011.

Recebido em Outubro de 2014 - Aprovado em Dezembro de 2014 


\title{
O desafio do regime de colaboração no novo Plano Nacional de Educação
}

\author{
The challenge of collaborative arrangment in the new National \\ Education Plan
}

El desafio del pacto de colaboración en el nuevo Plan Nacional
de Educación

Luiz Araujo'

\section{Resumo}

Este artigo discute os desafios do regime de colaboração no contexto do novo Plano Nacional de Educação, aprovado pela Lei Federal 13.005/2014. Partindo do reconhecimento de que o modelo de federalismo brasileiro é uma combinação entre o desejo de descentralização de poder e a histórica primazia do papel regulador e indutor do poder central em nosso país, o artigo evidencia como se deu o debate sobre o regime de colaboração no PNE e qual o cenário futuro desenhado a partir do plano. Por fim, o texto conclui destacando que o enfrentamento às desigualdades educacionais, agravadas pelo modelo federativo atual, passa por rever o papel da União no financiamento da educação, mas especialmente, passa pelo desenvolvimento de políticas redistributivas reguladas pelo governo central, única forma de induzir comportamentos mais equânimes na aplicação dos recursos na área educacional.

Palavras-chave: Regime de Colaboração; Federalismo; Plano Nacional de Educação; Financiamento da Educação.

\begin{abstract}
:
This article discusses the challenges of collaborative arrangement in the new National Education Plan, approved by Federal Law 13.005/2014. Recognizing that the Brazilian federalism model is a combination of the desire of power decentralization and the historical primacy of the central regulatory role and power of the inductor in our country, the article shows how was the debate on the collaborative arrangment in PNE and what the future scenario drawn from the plane. Finally, the text concludes highlighting that the solution to educational inequalities, aggravated by the current federal model, needs the revision of the Union's role in education financing, but especially through the development of redistributive policies regulated by the central government, that is the only way to induce more equitable behavior in the application of resources in education.
\end{abstract}

Keywords: Collaborative arrangment; Federalism; National Education Plan; Education financing. 


\section{Resumen:}

Este artículo aborda los desafíos del pacto de colaboración en el nuevo Plan Nacional de Educación, aprobado por la Ley Federal 13.005/2014. Reconociendo que el modelo del federalismo brasileño es una combinación de la voluntad de descentralización del poder y la primacía histórica del papel regulador central del poder central en nuestro país, el artículo muestra cómo fue el debate sobre el pacto de colaboración en PNE y como será el escenario futuro dibujado por el plan. Por último, el texto concluye destacando que enfrentar las desigualdades educativas, agravados por el modelo federativo actual, incluye revisar el papel de la Unión en la financiación de la educación, pero en especial a través del desarrollo de políticas redistributivas regulados por el gobierno central, como la única manera de inducir un comportamiento más equitativo en la aplicación de los recursos en la educación.

Palabras-clave: Pacto de colaboración; Federalismo; Plan Nacional de Educación; Financiamiento de la Educación.

\section{Introdução}

O debate sobre regime de colaboração está circunscrito à forma de funcionamento do federalismo brasileiro. Conceituar um país como federal é difícil, pois existe uma clara dificuldade para construir uma formulação que fosse aceita universalmente, inclusive mesmo a teoria política encontraria dificuldade para precisar qual seria a divisão de poder adequada e o formato institucional correto para que dado Estado possa ser denominado de federado (FIORI, 1995).

Mas em todas as definições sobre federalismo estão presentes algumas características, dentre elas a existência de uma

(...) dupla autonomia territorial do poder político, ou seja, na qual se distinguem duas esferas autônomas de poder: uma central, que constitui o governo federal, e outra descentralizada, que constitui os governos-membro, sendo que ambas têm poderes únicos e concorrentes para governar sobre o mesmo território e as mesmas pessoas (SOARES, 1998, p.3).

O Brasil se reivindica desde a Constituição de 1891 enquanto uma República Federativa. É verdade que o federalismo brasileiro buscou inspiração na experiência americana para formatar as suas instituições, mas as diferenças devem ser prontamente anotadas. As características desiguais do desenvolvimento das diversas regiões são uma marca constitutiva do federalismo brasileiro, o qual não convive com características de plurinacionalidades ou distinções religiosas que justificassem o modelo. Em verdade, o estado brasileiro nunca reconheceu e/ou utilizou como pré-requisito para sua organização institucional a existência de nacionalidades originárias, ou seja, as várias etnias indígenas nunca foram levadas em consideração na formatação dos desenhos institucionais (SOUZA, 2005).

O modelo de federalismo brasileiro reconheceu autonomia para três entes federados: a União, os Estados e os Munícipios, e inscreveu no texto constitucional as responsabilidades de cada um destes entes federados. Em termos teóricos, a federação advém de um pacto que implica a igualdade de autonomia de seus membros e a mesma possibilidade de participação para a construção da vontade política do estado federal. Assim, o equilíbrio federativo "depende da dosagem das competências e da garantia de fontes de recursos suficientes para que cada ente possa preservar sua autonomia financeira e assim sustentar os encargos decorrentes da prestação de serviços de sua competência" (Martins, 2011, p. 29).

Porém, o modelo de federalismo brasileiro está inserido nas denominadas "soluções de compromisso", tão características das formulações que emergem do processo constituinte de 1988, e é uma combinação entre o desejo de descentralização de poder e a histórica primazia do papel regulador e indutor do poder central em nosso país.

O processo de globalização econômica que se aprofundou no mundo na década seguinte à promulgação do texto constitucional provocou desequilíbrios na fórmula federativa brasileira. Este processo é caracterizado 
pelo despojamento, de uma forma cada vez mais acentuada, dos governos nacionais diante das suas clássicas atribuições, e no interior de cada país o mesmo processo se reproduz através de um "efeito cascata", sendo que o governo central saqueia e viola municípios e estados. Estes, por sua vez, também aplicam essa receita aos municípios. Enfim, o arranjo federativo constitucionalmente pactuado é tornado letra morta (RODRIGUES, 2012).

Neste contexto de reforma do estado, "a descentralização passou a ser encarada como um fator capaz de gerar eficiência no sistema de oferta de políticas públicas. Tal descentralização veio acompanhada da centralização no processo de definição de políticas" (CRUZ, 2012, p.71). De forma contraditória, enquanto a Carta permitiu a alocação de mais recursos para unidades subnacionais, diminuindo receitas do poder central, ao mesmo tempo foram criados sistemas de controle em um movimento re-centralizador, cujo exemplo mais paradigmático foi a aprovação, na década seguinte, da Lei de Responsabilidade Fiscal. Além disso, presenciouse um movimento de recomposição da base tributária nas mãos da União por meio de criação de contribuições sociais, as quais fugiram da necessidade de repartição com unidades subnacionais e a redefinição de alíquotas.

Quase três décadas de vigência do modelo federativo promulgado em 1988 não foram suficientes para que as regras de repartição de recursos e responsabilidades fossem devidamente regulamentadas. O parágrafo único do seu artigo 23 continua sem o devido detalhamento e o esperado regime de colaboração entre os entes federados é ainda impreciso e desequilibrado.

Esta situação fica evidente ao analisarmos a distribuição dos recursos destinados à educação pública por entes federados. O último dado disponível (2012) demonstra que a União contribui com 18,2\% dos recursos aplicados, participação bastante desproporcional ao seu potencial arrecadatório. Essa fraca participação, que não sofreu variações na última década (em 2000 a União participou com 17,9\%), sobrecarrega os demais entes federados na prestação dos serviços educacionais e reforça os traços desiguais na oferta educacional, ou dizendo de outra forma, favorece a existência de diferentes padrões de qualidade.

\section{O debate sobre regime de colaboração no PNE}

O artigo 211 da Constituição Federal, reconhecendo a complexidade do modelo desconcentrado de prestação de serviço educacional instituído pelos artigos precedentes afirma que "a União, os Estados e os Municípios organizarão em regime de colaboração seus sistemas de ensino". Tal afirmação é oriunda do caráter concorrencial da matéria educacional, pois é afeita a todos os entes. Porém, "se temos uma educação nacional, não temos um sistema nacional de educação. Nacional é a educação, não o sistema" (CURY, 2007, p. 124).

A falta de regulamentação de um regime de colaboração na área educacional torna a tarefa de formulação e posterior implementação de um Plano Nacional de Educação ainda mais complexa. Independente desta lacuna, articular metas e estratégias a serem cumpridas durante dez anos por 5570 municípios, 26 estados, um Distrito Federal e a União, por si só envolve muitas variáveis e enormes dificuldades operacionais, exigindo um nível de trabalho conjunto inexistente em nosso país.

O termo "regime de colaboração" aparece 21 vezes no texto da Lei n 13.005 de 25 de junho de 2014. Porém, é forçoso registrar que após vinte e seis anos de vigência da Constituição Federal e de sua previsão de materialização de um regime de colaboração, uma parte das citações ainda ficaram no terreno das boas intenções.

Os avanços mais relevantes na busca de criar um regime de colaboração estão inscritos no artigo $7^{\circ}$ da referida norma e em alguns dos seus parágrafos. No caput do artigo é repetida a necessidade de atuação conjunta dos entes federados, visando o alcance das metas e estratégias do plano, mas no parágrafo $5^{\circ}$ temos a obrigação de constituir uma "instância permanente de negociação e cooperação entre a União, os Estados, o Distrito Federal e os Municípios". E no parágrafo $6^{\circ}$ é dito que "o fortalecimento do regime de colaboração entre os Estados e respectivos Municípios incluirá a instituição de instâncias permanentes de negociação, cooperação e pactuação em cada Estado". 
A falta de regulamentação do regime de colaboração gerou dois fenômenos nocivos ao equilíbrio federativo e à garantia do direito à educação. De um lado, houve clara sobrecarga de alguns entes federados, especialmente os municípios, que assumiram mais responsabilidades do que previsto na Constituição (a oferta do ensino fundamental é exemplar) e tais atribuições não foram acompanhadas de alocação de recursos proporcionais. De outro lado, houve concorrência entre estados e municípios e uma relação de subordinação da esfera municipal, fruto do padrão de relacionamento político existente em muitas unidades da federação.

A tradição patrimonialista ganha farto espaço de teimosa persistência, regulando-se caso a caso, na forma de convênios pontuais e temporários, decretos ocasionais e, até mesmo, acordos informais entre "autoridades educacionais". É evidente que, num quadro destes, os princípios proclamados pela Constituição ficam sumariamente relativizados ao sabor do entendimento político dos governos de turno em cada unidade federada (ABICALIL, 2002, p. 256).

As redações dos dois parágrafos, caso se concretizem, colaboram para diminuir o cenário descrito por Carlos Abicalil há doze anos e que permanece bastante representativo das relações entre os entes federados em nosso país.

Além disso, o exemplo de funcionamento da área da saúde, onde existem instâncias de negociação entre os entes (trilateriais e bilaterais) poderá servir de parâmetro para a construção de uma nova experiência na área educacional. A diferença, que é muito relevante, é que a saúde optou por um Sistema Único já durante o processo constituinte e a educação manteve um formato desconcentrado de funcionamento e só recentemente a discussão sobre um Sistema Nacional de Educação voltou a ganhar força. Aliás, o novo Plano Nacional de Educação, no seu artigo 13, estabelece um prazo para que esta lacuna seja superada.

Art. 13. 0 poder público deverá instituir, em lei específica, contados 2 (dois) anos da publicação desta Lei, o Sistema Nacional de Educação, responsável pela articulação entre os sistemas de ensino, em regime de colaboração, para efetivação das diretrizes, metas e estratégias do Plano Nacional de Educação.

Em diversas estratégias do PNE a questão do regime de colaboração se apresenta. No geral, mesmo que exista previsão constitucional clara de a qual ente federado cabe a responsabilidade pelo provimento educacional de dada etapa ou modalidade, a capacidade do ente em cumprir a meta ou estratégia estabelecida no plano é insuficiente para que a mesma se concretize. Assim, cabe ajuda dos demais entes federados.

Na Meta 01, que trata da expansão das matrículas de educação infantil, o regime de colaboração aparece em três estratégias. Ele se faz necessário para garantir as "metas de expansão das respectivas redes públicas de educação infantil segundo padrão nacional de qualidade, considerando as peculiaridades locais" (Estratégia 1.1). Para que seja feito o levantamento da demanda de creche para a população de até 3 (três) anos também a lei reconhece a necessidade de apoio dos demais entes aos municípios (Estratégia 1.3). E, na estratégia mais concreta, a manutenção e ampliação de "programa nacional de construção e reestruturação de escolas, bem como de aquisição de equipamentos, visando à expansão e à melhoria da rede física de escolas públicas de educação infantil”, deverá também contar com apoio, neste caso, mesmo que não de maneira explícita, a Estratégia 1.5 se refere a aporte federal já existente e que necessita de ampliação.

Um dos desafios do novo Plano Nacional de Educação é ampliar o número de escolas com tempo integral na educação básica. A Meta 06 estabelece dez anos para o Brasil ter tempo integral em 50\% (cinquenta por cento) das escolas públicas, de forma a atender, pelo menos, 25\% (vinte e cinco por cento) dos(as) alunos(as) da educação básica. Para isso será fundamental um "programa de construção de escolas com padrão arquitetônico e de mobiliário adequado para atendimento em tempo integral", o qual precisará ser feito em regime de colaboração, conforme Estratégia 6.2. Da mesma forma, a Estratégia 6.3 preconiza colaboração para que se constitua um "programa nacional de ampliação e reestruturação das escolas públicas", pois o desafio é garantir que as atuais escolas tenham quadras poliesportivas, laboratórios, inclusive de informática, espaços para atividades culturais, bibliotecas, auditórios, cozinhas, refeitórios, banheiros e outros equipamentos.

A Meta 7 se propõe a fomentar a qualidade da educação básica em todas as etapas e modalidades e na sua Estratégia 7.19 o novo PNE quer "institucionalizar e manter, em regime de colaboração, programa nacional 
de reestruturação e aquisição de equipamentos para escolas públicas, visando à equalização regional das oportunidades educacionais". Não se pode pretender alcançar indicadores de qualidade sem que as oportunidades educacionais sejam equalizadas, posto que a oferta escolar pública é muito desigual entre as regiões e entre os municípios. Por isso, também na Estratégia 7.21 é colocada a necessidade dos entes federados colaborarem para a construção de "parâmetros mínimos de qualidade dos serviços da educação básica".

Seguindo o mesmo caminho aparecem quatro citações nas Metas 9 e 10, que tratam da educação de jovens e adultos, e que também reclamam por uma atuação colaborativa entre os entes federados.

Se a quase totalidade das metas do Plano precisam de algum nível de colaboração entre os entes, certamente a Meta 15 é representativa desta necessidade. Para garantir uma política nacional de formação dos profissionais da educação, ou seja, para que se desenvolvam esforços formativos para mais de dois milhões de trabalhadores da área educacional é necessário engajamento das instituições do ensino superior (as públicas majoritariamente federais, mas também estaduais) e alocação de recursos que permita a estes trabalhadores se ausentar do local de trabalho para estudar, exigindo enorme esforço financeiro de estados e municípios. Aqui também se fez presente a reivindicação de um regime de colaboração, inclusive para que seja implantada no prazo de um ano, uma política de formação para os não-docentes (Estratégia 15.11).

Da mesma forma, o esforço para elevar o nível de professores com pós-graduação lecionando na educação básica exigirá trabalho conjunto dos entes federados. Pelo menos esta é a assertiva presente na Estratégia 16.1. E, ainda se tratando de docentes, na Estratégia 18.5 é estabelecido que se realize "anualmente, a partir do segundo ano de vigência deste PNE, por iniciativa do Ministério da Educação, em regime de colaboração, o censo dos(as) profissionais da educação básica de outros segmentos que não os do magistério".

Por fim, para completar esta compilação da presença do termo "regime de colaboração" no texto do novo Plano Nacional de Educação, cabe citar a Estratégia 20.9.

20.9) regulamentar o parágrafo único do art. 23 e 0 art. 211 da Constituição Federal, no prazo de 2 (dois) anos, por lei complementar, de forma a estabelecer as normas de cooperação entre a União, os Estados, o Distrito Federal e os Municípios, em matéria educacional, e a articulação do sistema nacional de educação em regime de colaboração, com equilíbrio na repartição das responsabilidades e dos recursos e efetivo cumprimento das funções redistributiva e supletiva da União no combate às desigualdades educacionais regionais, com especial atenção às regiões Norte e Nordeste.

Apesar de redundante, a Estratégia transcrita acima reforça a necessidade de se regulamentar o dispositivo constitucional no que diz respeito à educação. E, passados tantos anos, a lei estabelece novo prazo, no caso dois anos, para que a lacuna seja preenchida por uma Lei Complementar. A referida norma deve seguir, dentre outras preocupações, o equilíbrio na repartição das reponsabilidades e tratar da efetivação do cumprimento das funções redistributivas que cabem à União.

Certamente a efetivação de ações redistributivas por parte da União passam pela equalização das oportunidades educacionais e este tema está profundamente associado à criação de um padrão mínimo de qualidade. A Constituição de 1988, ao instituir a educação como um direito social (caput do Artigo $6^{\circ}$ ), expresso como direito de todos e dever do Estado (Artigo 205), não partiu de uma situação de inexistência de oferta educacional. Pelo contrário, os avanços ali registrados são fruto da consolidação de um sistema educacional descentralizado e com padrões de oferta muito diferenciados.

Diante de um quadro em que a oferta educacional não estava garantida para todos e, ao mesmo tempo, havia forte questionamento social acerca da qualidade dos serviços prestados (neste momento muito subordinado à não garantia de permanência dos estudantes que conseguiam ingressar nas escolas), a Constituição consignou como um dos princípios que deveriam reger o ensino a "garantia de padrão de qualidade" (Artigo 206, VII).

Foi justamente a busca por concretizar este princípio constitucional que se transformou em um dos debates mais polêmicos durante a tramitação do novo Plano Nacional de Educação. O estabelecimento de um padrão mínimo de qualidade foi materializado no indicador desenvolvido pela Campanha Nacional pelo Direito à 
Educação² e sistematizado por Carreira e Pinto (2007) denominado de Custo Aluno-Qualidade. A polêmica se deu principalmente sobre o papel que deveria caber à União após o estabelecimento do referido padrão, ou seja, detectando que muitos estados e municípios estariam abaixo do patamar de qualidade determinado pelo referido indicador, qual seria a participação financeira da União para que o Brasil possuísse este novo patamar de oferta educacional.

20.10) caberáà União, na forma da lei, a complementação de recursos financeiros a todos os Estados, ao Distrito Federal e aos Municípios que não conseguirem atingir o valor do CAQi e, posteriormente, do CAQ.

Depois de idas e vindas legislativas, o texto da Estratégia 20.10, transcrito acima, foi aprovado. Seu conteúdo é diretamente vinculado ao regime de colaboração e à discussão da revisão dos papéis dos entes federados no financiamento educacional. A referida estratégia ensejará uma maior participação financeira da União no financiamento da educação básica. Estudos desenvolvidos pela Fineduca³ (2014) e por Araujo (2013) apontam para a necessidade de significativo aporte financeiro para que o Custo Aluno-Qualidade Inicial seja efetivado. E a redação remete para a União a obrigação de suprir a carência de recursos dos entes federados que não alcançarem o patamar estabelecido enquanto padrão mínimo de qualidade.

\section{Os desafios dos próximos anos}

Comungo da apreciação feita por Araújo (2010) sobre o desafio presente na regulamentação do regime de colaboração.

No processo de regulamentação do regime de colaboração, há que se levar em conta um grande desafio para as relações intergovernamentais no Brasil: 0 estabelecimento de uma justa distribuição de poder, autoridade e recursos entre os entes federados, garantindo a independência e interpenetração dos governos nacional e subnacionais sem que haja comprometimento de um projeto de desenvolvimento nacional, no qual um dos elementos é a educação (ARAUJ0, 2010, p. 764).

Com a aprovação de um novo Plano Nacional de Educação, o debate sobre a regulamentação do regime de colaboração passou a estar presente na ordem do dia da pauta educacional. A "justa redistribuição de poder, autoridade e recursos entre os entes federados" é o grande desafio dos próximos anos. Há uma certeza de que as metas e estratégias presentes no PNE somente serão cumpridas se houver esta redistribuição de responsabilidades e recursos.

Dentre as polêmicas embutidas neste desafio está uma contradição muito relevante. De um lado, existe uma demanda reprimida de maior participação dos demais entes federados nas decisões de alocação de recursos e a descentralização destes de forma proporcional às responsabilidades assumidas. De outro, são justamente as políticas reguladas pela instância nacional que mais eficácia têm mostrado no combate à desigualdade entre os estados e municípios (ARRETCHE, 2010; ARAUJO, 2013). Encontrar o equilíbrio é o desafio teórico e prático. Dito de outra forma, combater as desigualdades passa por rever o papel da União no financiamento, mas necessariamente passa pelo desenvolvimento e/ou aprofundamento de políticas redistributivas reguladas pelo governo central, única forma de induzir comportamentos mais equânimes na aplicação dos recursos na área educacional.

A implementação do Custo Aluno-Qualidade Inicial, previsto para dois anos, conforme a Estratégia 20.6 do PNE, colocará a necessidade de definição, ao mesmo tempo, dos parâmetros de qualidade aceitos socialmente e historicamente pelo Brasil, mas também exigirá, em paralelo, acordos entre os entes federados das formas, dos prazos e da participação financeira de cada ente na materialização do referido padrão.

2 A Campanha Nacional pelo Direito à Educação, neste texto também denominada simplesmente como Campanha, é uma rede da sociedade civil que tem por missão atuar pela efetivação e ampliação dos direitos educacionais para que todas as pessoas tenham garantido seu direito a uma educação pública, gratuita e de qualidade no Brasil. Articula mais de $\mathbf{2 0 0}$ grupos e entidades distribuídas por todo o País. Entre outras conquistas, a Campanha liderou a incidência da sociedade civil na elaboração e regulamentação do Fundeb.

3 A Associação Nacional de Pesquisa em Financiamento da Educação, Fineduca, é uma associação civil de direito privado, que esteve presente nos debates legislativos do novo PNE. 
Da mesma forma, a constituição de instâncias negociadoras entre os entes federados trará à tona o debate sobre o Sistema Nacional de Educação, temática mais ampla do que apenas a repartição de responsabilidades e recursos, que ensejará reflexões acerca dos limites da autonomia normativa dos entes, por exemplo. Uma nova norma legal sobre o tema e a reformulação da Lei de Diretrizes e Bases da Educação se tornarão necessidades prementes.

A esperança é que tais reformulações tornem a oferta de educação uma ferramenta mais efetiva no combate às desigualdades, sejam elas sociais, raciais, de gênero ou territoriais.

\section{Referências}

ABICALIL, C. Sistema Nacional de Educação Básica: nós da avaliação? Revista Educ. Soc., Campinas, v. 23, n. 80, setembro/2002, p. 253-274. Disponível em <http://www.cedes.unicamp.br>

ARAUJO, G. Constituição, federação e propostas para o novo Plano Nacional de Educação: análises das propostas de organização da educação brasileira a partir do regime de colaboração. Revista Educ. Soc., Campinas, v. 31, n. 112, p. 749-768, jul.-set. 2010. Disponível em <http://www.cedes.unicamp.br>

ARAUJO, L. Limites e possibilidades da redução das desigualdades territoriais por meio do financiamento da educação básica. 416f. Tese (Doutorado em Educação). Faculdade de Educação, Universidade de São Paulo, 2013.

ARRETCHE, M. Federalismo e igualdade territorial: uma contradição em termos. Revista de Ciências Sociais, Rio de Janeiro, v. 53, n. 3, 2010, p. 587-620.

BRASIL. Constituição Federal. Diário Oficial da República Federativa do Brasil, Brasília, DF, 05 out. 1988. p. 01 (Anexo).

Lei $\mathbf{n}^{\circ} \mathbf{1 3 . 0 0 5}$, de 9 de janeiro de 2001. Aprova o Plano Nacional de Educação e dá outras providencias. Brasília, DF. Disponível em: http://www.planalto.gov.br/CCIVIL 03/ Ato2011-2014/2014/Lei/L13005.htm. Acesso em 10 de julho de 2014.

CARREIRA, D.; PINTO, J. Custo aluno-qualidade inicial: rumo à educação pública de qualidade no Brasil. São Paulo: Global; Campanha Nacional pelo Direito à Educação, 2007.

CRUZ, R. E. Federalismo e Educação: um pacto a se rever. Retratos da Escola, Brasília, v. 6, n. 10, p.65-78, jun. 2012. Semestral.

CURY, C. Sistema Nacional de Educação: desafio para uma educação igualitária e federativa. Revista Educ. Soc., Campinas, vol. 29, n. 105, p. 1187-1209, set./dez. 2008. Disponível em <http://www.cedes.unicamp.br>

FIORI, J. O federalismo diante do desafio da globalização. In: AFFONSO, Rui; SILVA, Pedro. A federação em perspectiva: ensaios selecionados. São Paulo: Fundap, 1995. p. 20-36.

MARTINS, P. Fundeb, federalismo e regime de colaboração. Campinas, SP: Autores Associados, 2011.

RODRIGUES, E. Território e soberania na globalização: Amazônia jardim de águas sedento. Belo Horizonte: Editora Fórum, 2012. 459 p.

SOARES, M. Federação, democracia e instituições políticas. Lua Nova (on line), São Paulo, n. 44, p.137-163, dez. 1998.

SOUZA, C. Federalismo, desenho constitucional e instituições federativas no Brasil pós-1988. Rev. Sociologia e Política. Curitiba, n. 24, jun. 2005. Disponível em http://migre-me/dOJul. Acesso em 05 dezembro de 2010.

Recebido em agosto de 2014 - Aprovado em setembro de 2014 


\title{
Recursos públicos para a educação: percentual irrevogável do PIB
}

\section{Resources for public education: irrevocable percentage of GDP}

\author{
Los recursos públicos para la educación: porcentaje irrevocable del PIB
}

\section{João A.C. de Monlevade ${ }^{1}$}

\section{Resumo:}

Este artigo intenciona apresentar uma leitura acerca da execução dos dispositivos da Lei $n^{\circ} 13.005$, de 25 de junho de 2014, que instituiu o novo Plano Nacional de Educação, em particular daqueles contidos na Meta 20, que trata do financiamento da educação brasileira. O texto apresenta e discute a evolução dos percentuais investidos em educação no Brasil, e analisa a proposição de vinculação deste investimento ao Produto Interno Bruto (PIB) do país. Ao final, o artigo conclui analisando o contexto e as dificuldades para a implementação do projeto de financiamento da educação contido no PNE.

Palavras-chave: Financiamento da educação; PIB; PNE.

\begin{abstract}
:
This article intends to present a reading on the implementation of Law No. 13,005, of 25th june 2014, which established the new National Education Plan, in particular about the contained in goal 20, which deals with the financing of Brazilian education. The paper presents and discusses the evolution of the percentage invested in education in Brazil, and analyzes the linking proposition of this investment to gross domestic product (GDP). Finally, the article concludes by looking at the context and the difficulties in implementing the education financing project contained in the PNE.
\end{abstract}

Keywords: Education financing; GDP; PNE.

\section{Resumen:}

Este artículo tiene la intención de presentar una lectura sobre la aplicación de las disposiciones de la Ley № 13.005, de 25 de junho de 2014, que estableció el nuevo Plan Nacional de Educación, en particular las contenidas en el Objetivo 20, que se ocupa de la financiación de la educación brasileña. El artículo presenta y discute la evolución del porcentaje invertido en educación en Brasil, y analiza la propuesta vinculante de esta inversión y el producto interior bruto (PIB). Por último, el artículo concluye observando el contexto y las dificultades en la aplicación del proyecto de financiamiento de educación contenida en el PNE.

Palabras-clave: Financiamiento de la Educación; PIB; PNE. 


\section{Introdução: Uma Metodologia para o Aperfeiçoamento do Plano}

O que pretendo com este artigo, fruto de muito diálogo e de longa reflexão sobre textos legais e propostas legislativas, é, antes de tudo, uma contribuição para a leitura e execução dos dispositivos da Lei $n^{\circ}$ 13.005, de 25 de junhol de 2014, que institui o Plano Nacional de Educação - PNE. Especialmente dos que se resumem na Meta 20 e em suas doze estratégias, sobre o financiamento das ações em educação escolar - básica e superior.

Como foi festejado durante os dolorosos quarenta meses de tramitação, reduziram-se as quase trezentas metas do PNE de 2001-2010 para as vinte do PNE agora em vigor. Entretanto, multiplicaram-se demais as estratégias, quase sempre sem sujeito definido para transformá-las em ações: chegaram a 254, sem considerar os dispositivos inscritos nos 14 artigos introdutórios, tanto ou mais importantes que elas. A verdadeira questão, porém, não estão nesses números. Para se atingir os objetivos do plano, é necessário que as metas, além de claras, contenham marcos graduais em seus indicadores quantitativos e que, acima de tudo, estejam "amarradas" por estratégias de responsabilidade definida entre os atores da República Federativa.

Por exemplo, na meta de atendimento a $50 \%$ da demanda potencial por creches e, sabendo-se que as matrículas em 2013 não atingiam a 25\% da população de zero a três anos de idade, impõe-se saber como deveremos estar no quinto ano de vigência do Plano - inclusive quanto ao percentual a ser atendido por instituições privadas com e sem fins lucrativos - e quais responsabilidades administrativas e financeiras serão assumidas por estratégias da União, dos estados e dos municípios. Na realidade, neste e em outros exemplos, de nada adiantaria a meta ser de 50\%, 70\% ou mesmo 100\% (como ocorre em relação às pré-escolas, tornadas obrigatórias pela Emenda Constitucional n 59, de 2009), se não ficarem claros os encargos federativos nas estratégias. Não ficaram, assim resta a esperança de os Planos Estaduais (PEE) e Municipais (PME) suprirem esta lacuna. No caso do financiamento da educação, não é diferente.

\section{Financiamento da Educação Pública: Evolução dos Percentuais Vinculados}

Segundo o art. 212 da Constituição, duas são as principais fontes de financiamento da educação básica e superior pública, que se responsabiliza hoje por perto de 50 milhões de matrículas: as receitas de impostos vinculados à manutenção e desenvolvimento do ensino (MDE) e a contribuição social chamada Salário Educação.

Desde a Independência, a oferta de escola gratuita foi viabilizada pelo uso de receita de tributos. De 1834 em diante, quando o encargo das escolas primárias e secundárias passou para as províncias, coube a estas investir crescentes verbas - da receita de seus tributos - na educação escolar. Por isso, tanto mais escolas tinha a província que arrecadava mais impostos e deles investia maior percentual em educação.

Com a crescente urbanização do país, ficou escancarada a desproporção entre a demanda por matrículas e a frágil oferta de recursos. A cada ano, no âmbito da União, de cada estado e de cada município, travava-se a disputa por um orçamento maior para as escolas públicas. Daí a luta, já no século XX, no período republicano, pela adoção, em lei, de um percentual de impostos para a Manuntenção e Desenvolvimento do Ensino - MDE. Do Manifesto dos Pioneiros para o texto da Constituição de 1934 - que pretendia democratizar o regime revolucionário de Getúlio Vargas - foi um pulo: em 1934, quando 75\% da população do Brasil moravam no campo e $25 \%$ nas cidades, foi fixado o primeiro formato de vinculação: $10 \%$ dos impostos da União, 20\% dos Estados e 10\% dos Municípios para a MDE.

$\mathrm{Na}$ Constituição de 1946, em razão do aumento da demanda e da presença mais significativa dos municípios na oferta de escolas públicas, fixou-se uma segunda formatação: 10\% da União, 20\% dos Estados e $20 \%$ dos Municípios.

Contraditoriamente, a Constituição de 1967 - quando a população urbana acabara de ultrapassar a rural, provocando a explosão de matrículas, inclusive por se dobrar a duração da escolarização obrigatória - conservou aos percentuais de impostos para a MDE dos Estados e Municípios e retirou o dever constitucional da União. 
Dali até 1988, exatamente quando o governo federal arrecadou as maiores receitas da história, o aumento de encargos financeiros de todas as esferas administrativas foi viabilizado pelo corte na qualidade da educação pública e nos salários de seus profissionais. Sofremos as consequências até hoje.

A luta do Senador João Calmon ainda está na lembrança de muitos de nós; em 1983 emplacou sua Emenda, que fixou 13\% dos impostos da União, 25\% dos Estados e 25\% dos Municípios - o que resultava em aproximadamente $26 \%$ de ganho real para a educação.

Finalmente, a Constituição de 1988 dispôs que 18\% dos impostos da União, 25\% dos Estados e 25\% dos Municípios se aplicassem em MDE - o que foi reafirmado pelo art. 69 da Lei no 9.394, de 1996, Lei de Diretrizes e Bases da Educação Nacional - LDB, com três detalhes importantes: a exclusividade para a educação pública, a possibilidade de aumento de percentuais vinculados nas constituições estaduais e o dispositivo do repasse a cada dez dias dos recursos do órgão financeiro para o "órgão responsável pela educação". Resolução do Conselho Nacional de Educação elucidou que por "órgãos responsáveis pela educação" na União, nos estados, no Distrito Federal e nos municípios são os respectivos conselhos e secretarias de educação.

Quanto ao Salário Educação, a história é mais curta e mais simples, tendo evoluído na mesma lógica. Em 1964 foi criado o percentual de 1,4\% na folha de contribuição dos empregados de cada empresa privada, destinado aos ensino primário, então de quatro anos; em 1972, com a ampliação do ensino obrigatório para oito anos (então denominado de $1^{\circ} \mathrm{grau}$ ), a alíquota passou a ser de 2,5\%, que se mantém até hoje, embora sua destinação deva cobrir toda a educação básica, de dezessete a dezoito anos de duração.

\section{$O$ referencial ao PIB: Do ex-post ao ex-ante}

Tanto no caso dos impostos quanto no do Salário Educação, percebe-se que não basta qualquer aumento de arrecadação para se fazer face às despesas obrigatórias com a educação pública.

É verdade que, desde 1934, houve um aumento real de arrecadação. A grande questão é analisar se o aumento das demandas por investimentos na educação não é superior ao crescimento da receita, incluídos os recursos provenientes de "atualização" dos percentuais de MDE.

Ora, três variáveis históricas reais incrementaram a necessidade de novos e vultosos investimentos: o aumento de demanda por escolarização (maior população urbana); aumento de demanda de escolaridade (novos níveis de ensino), rumo à educação superior; aumento das exigências de qualidade do processo educativo escolar. Essas razões não somente fatos observáveis e registrados estatisticamente, como tendem a se acentuar nos próximos anos. As demandas quantitativas - mesmo com a queda da taxa de natalidade - são crescentes, inclusive numa faixa nova e pouco atendida, a da educação infantil. Já as demandas qualitativas se impõem pelo advento de novas tecnologias, pela necessidade de maior capacitação para o mundo do trabalho e pelo imperativo da volta à jornada curricular integral, como única forma provada de se superar o fosso das desigualdades sociais e os desafios da qualidade na aprendizagem.

Nesse contexto, a educação comparada, que analisa os diversos sistemas nacionais de educação, tem recorrido a um índice para avaliar o esforço de cada País em adotar políticas públicas na educação: trata-se do percentual do Produto Interno Bruto (PIB) que cada um aplica em sua rede de ensino, oferecido à população de forma gratuita, pelo menos na faixa da educação obrigatória.

A UNESCO tem-se esmerado em publicar as tabelas desses percentuais de aplicação, que são obtidos ex-post, ou seja, depois de verificado o total de gastos públicos em educação num determinado ano, divide-se esse número pelo valor do PIB obtido no mesmo ano. Embora não se deva desconsiderar os números absolutos (montante do PIB, total da receita pública, população estudantil, escolaridade da população - para citar alguns mais importantes), o número relativo, expresso pelo percentual de recursos públicos aplicados em educação em relação ao PIB, parece ser um dos indicadores mais importantes para se avaliar a política de educação de cada país no concerto das nações. 
É corrente a opinião de que o Brasil tem gasto (ou investido) em educação um percentual baixo em relação a seu PIB - números que vão de 3\% a 5\% nos últimos trinta anos, com subidas e descidas. Assim, foi "natural" se construir na opinião pública, principalmente entre os educadores, um consenso de que se deveria investir mais e mais - inclusive para se propiciar melhores salários para os profissionais. De 1990 a 200, tramitou no Congresso Nacional um projeto de lei fixando um PNE com previsão de despesas públicas em educação equivalentes a $10 \%$ do PIB. A Lei $n^{\circ} 10.172$, de 9 de janeiro de 2001, fixou 7\%, percentual que foi vetado pelo poder executivo com razões pífias, as quais escondiam argumentos tão poderosos quanto impublicáveis.

De 2003 em diante, existe uma sensação de que se aumentaram os gastos em relação ao PIB. Por duas razões, entre outras. A primeira foi o aumento real de arrecadação de impostos para a educação, acrescida pelo "dinheiro novo" da complementação da União ao Fundo de Manutenção e Desenvolvimento da Educação Básica e Valorização dos Profissionais da Educação - FUNDEB, que contribuíram para uma distribuição mais equânime e para um controle social mais visível, embora ineficaz na maioria dos entes federados. Focalizando somente o Imposto sobre Circulação de Mercadorias e Serviços (ICMS) - tributo de maior receita no Brasil, sua arrecadação em valores correntes parte de $R$ \$ 94,3 bilhões em 2001 e chega a $R$ \$ 270,7 bilhões em 2010 - 187\% de aumento diante de uma inflação pouco superior a 100\% no mesmo período. A segunda, muito propalada pela mídia oficial, foi a desativação da Desvinculação dos Recursos da União (DRU), que sequestrava mais de $20 \%$ dos impostos federais vinculados à MDE. A informação oficial dá conta de que se evoluiu de 3,9\% do PIB em 2003 para $5 \%$ em 2009.

Nada mais natural, portanto, que os educadores e outros cidadãos envolvidos na Conferência Nacional de Educação (Conae), realizada em abril de 2010, ainda lembrados do veto de Fernando Henrique Cardoso à meta de $7 \%$ do PIB e embalados pelo crescimento econômico e aumento dos investimentos em educação do Governo Lula, advogassem que se fixasse no PNE uma meta de aplicação de 10\% dos recursos públicos em relação ao PIB. Cumpre afirmar que a Emenda Constitucional n 59, de 2009, tinha acrescido ao art. 214 o dispositivo de obrigar o PNE a fixar a meta de aplicação de recursos relativos ao PIB.

\section{Sete ou dez por cento do PIB para a Educação ?}

Esse dilema, na verdade, não me parece ser o principal no financiamento da educação pública no Brasil, desde que se assegure um crescimento de despesas proporcional ao aumento quantitativo e qualitativo das demandas. O nó da questão é como transformar uma medida de avaliação (ex-post) em uma meta (ex-ante) e se garantir a efetividade desta meta numa República Federativa, com desproporcionalidade nas receitas e dispersão de responsabilidades.

O que significa transformar uma medida de avaliação tão ampla e global numa meta objetiva? Explicamonos. Uma coisa é ter no orçamento a vinculação de impostos e projetar a destinação de $25 \%$ ou $30 \%$ para a MDE, mês a mês, em cada estado e município - ou de 18\% na União. Os erros na previsão de receitas têm sido desprezíveis, tal o grau de cientificidade dos exercícios dos economistas. O mais difícil é a realização da despesa e sua qualidade como investimento - não como simples gasto, ou pior, como desperdício. Mudar o percentual do PIB, porém, do ex-post para o ex-ante, é quase um salto de trapezista. Primeiro, porque não se sabe qual o valor do PIB que o País alcançará até 31 de dezembro. Segundo, porque as receitas e despesas de impostos, de Salário Educação e de outros tributos que comporão o percentual do gasto em educação são sujeitos não somente a previsões, como a imprevistos. Terceiro, porque o percentual final da aplicação em educação pública será resultado da soma de diversos percentuais - da União, do conjunto de 26 Estados e do DF e do "pequeno" coletivo de 5.564 Municípios, que variam de um mil a onze milhões de habitantes.

Chegar a $7 \%$ em quatro anos, como afirmou a plataforma do Governo Dilma, era uma operação complexa, que supunha não somente marcos gradativos, a serem definidos no conjunto dos orçamentos públicos, conjugando 
compromissos da União, dos estados e dos municípios. Entretanto, ao fim do terceiro ano de seu governo (2013), não se chegou a 6\%. Pode-se ter também um aumento enganoso em 2014, em vista da estagnação do PIB, qualquer aumento de despesa em educação, que se dissolveria pelo crescimento do PIB, vai-se tornar mais visível. Corremos o "risco" de chegar a 6,5\% do PIB em 31 de dezembro de 2014 (ou seja, quase 10\% no percentual de investimento) com ganho real de investimento abaixo de 5\% - embora os prognósticos caminhem em sentido contrário, dada a redução de arrecadação de tributos da União já visível nos meados do ano.

Essa complexidade leva alguns estudiosos e políticos a invalidar o critério de melhorar a educação via percentual do PIB - preferindo as medidas de aumento real de arrecadação ou até mesmo de aumento dos percentuais. Contra essa última hipótese trabalham os dados históricos da evolução dos percentuais de MDE e do Salário Educação e a pressão dos outros setores da economia, que seriam necessariamente afetados - a não ser que ocorressem crescimentos do PIB acima de 5\% anuais, o que é muito improvável nos próximos dez anos.

Tenho uma posição média: se na administração pública temos um precedente de sucesso na política de ajuste fiscal, que é a composição do "superávit primário", como percentual do PIB oriundo da diferença entre receitas e despesas da União e dos entes federados, por que se arguiria impossibilidade ou impraticabilidade da mesma estratégia de gestão em relação à educação pública?

Ocorre que existe um componente político explosivo, tanto ou mais que no caso do "superávit primário", dentro do regime de cooperação dos entes federados no financiamento da educação: quem mais arrecada, a União, tem sido quem menos aplica em MDE desde que o Brasil é independente. E quem tem despendido cada vez mais é, exatamente, quem menos arrecada - o conjunto dos municípios. Como remontar essa equação? $\mathrm{Na}$ realidade, bastaria classificar uma série de gastos como "aplicações em educação" e poder-se-ia ganhar até 1\% do PIB: merenda escolar, bolsa-família, aposentadorias e pensões de educadores.

É preciso, ao afirmar as metas e estratégias, ter conceitos claros e definidos, para, então, distribuir a responsabilidade dos aumentos de encargos em cada conjunto federativo no alcance dos 7, 8, 9, até 10\% do PIB em educação. Traduzindo em reais, para 2014, em valores correntes, estima-se um PIB de $R \$ 5$ trilhões. O que significa que $7 \%$ seriam $R \$ 350$ bilhões; 10\%, R\$ 500 bilhões. Em 2013, os dados dos "dispêndios" em educação - neles incluída a maior parte de MDE - oscilam entre $R \$ 260$ e $R \$ 280$ bilhões. De onde brotariam os $R \$ 70$ ou $R \$ 90$ milhões que faltam?

No campo da ciência do financiamento, urge adotar-se um conjunto de conceitos e uma metodologia de interpretação idênticos para todas as contas que compõem a aplicação de recursos públicos em educação, inclusive traduzidos em artigos da LDB, semelhantes ao 70 e 71 que regulam o que é e o que não é despesa de MDE. Nessa hora, ensino é uma coisa; educação é outra, mais ampla. E são mesmo conceitos distintos. Mas não se pode alargar tanto que de ensino público se chegue a "educação societária permanente", nessa toada já teríamos até ultrapassado os $10 \%$ do PIB...

\section{As responsabilidades da União, dos estados, do DF e dos municípios para o aumento progressivo e sustentável do percentual do PIB aplicado em educação}

Grosso modo, pela legislação atual, cabe à União a educação superior e profissional; aos estados, o ensino médio em todas as suas modalidades e parte do ensino fundamental; aos municípios, a educação infantil e parte do fundamental; e ao Distrito Federal, toda a educação básica. Na realidade, quase todos os estados têm universidades e matrículas remanescentes na educação infantil, tanto quanto os municípios ainda sustentam cursos de ensino médio, até mesmo profissionais. A iniciativa privada, que já foi hegemônica na oferta de "ginásios e colégios" até 1960, atende hoje a 15\% das matrículas na educação como um todo, principalmente na educação superior (75\%), na profissional (50\%) e na infantil (40\%). Essa variação se reflete nas diferenças de gastos das diversas redes, de que decorrem variados percentuais em relação ao PIB.

Infelizmente, não conto com dados confiáveis, classificados pela ciência contábil, para descrever os percentuais de aplicação de recursos financeiros de cada um dos conjuntos em relação ao PIB. Em 2010, o PIB em valores 
nominais foi de $\mathrm{R} \$ 3,675$ bilhões. Diz-se que a União, naquele ano, não aportou recursos superiores a $1 \%$ do PIB ( $R \$ 36,75$ bilhões). Talvez seja uma questão de interpretação: trata-se do que ela aplicou diretamente em sua rede ou do que ela destinou a toda a educação escolar, incluindo as transferências? No segundo caso, só para a complementação do Fundeb e para as cotas estaduais e municipais do Salário Educação, foram mais de $R \$ 15$ bilhões. E como classificamos as transferências dos Fundos de Participação dos Estados e dos Municípios (FPE e FPM), dos quais 25\% são destinados à MDE? Nove estados da Federação têm no FPE receita maior que do próprio ICMS para a educação; e cerca de 2.000 Municípios "sobrevivem" do FPM - tal a penúria das receitas próprias e das transferências de ICMS e IPVA. Nessa linha de raciocínio, dos 5\% do PIB de 2010, 2\% teria derivado de arrecadação da União - a metade "transferida" para os entes federados. De qualquer maneira, uma análise fria dos números nos últimos dez anos revelará que o maior crescimento das despesas se deveu ao esforço fiscal da União.

Para se obter um diagnóstico preciso, de que sejam extraídas estratégias e ações para o PNE, para os PEE e para os PME impõe-se uma uniformização de critérios. Com este artigo, tento contribuir para clarear a questão das receitas e investimentos de cada uma das esferas do poder. Tanto na hipótese dos 7\% quanto na dos 10\% do PIB para a educação, ousaria propor como medida de aplicação dos recursos públicos arrecadados por cada conjunto, independente de onde foi investido, a seguinte proporção: dois quintos da União, outros dois dos estados e DF e um quinto dos municípios. Evidentemente, uma vez conhecidas essas proporções nos balanços de 2013 e 2014, esta proposta estaria sujeita à avaliação e a uma programação de ajuste gradual, sempre em direção à qualidade da educação pública, porque no mundo real e nas finanças, não se fazem saltos.

Cumpre agora indicar as possíveis fontes dos novos investimentos em educação escolar pública e a enumeração das estratégias gerais, entre as quais enfatizo o que chamo de "compromissos federais".

\section{Fontes para a expansão dos investimentos públicos em educação}

No âmbito da União, pode-se, além de se majorar levemente o percentual de impostos para a MDE (de 18\% para 20\%) e de elevar a alíquota do Salário Educação para 3,5\%, pensar numa destinação para a educação em geral das Contribuições Sociais (Cofins, CSLL, PIS-PASEP, etc), gradativa até 10\% em cinco anos. Tais medidas, a médio prazo, poderiam dobrar a capacidade de investimento da União na educação superior e básica, especialmente para aumentar a complementação do Fundeb e ampliar a rede de universidades e institutos federais. Caberia também à União potencializar a arrecadação do ITR (hoje absurdamente baixa, de cerca de $\mathrm{R} \$ 1,00$ por hectare) e direcionar as receitas dos royalties do petróleo para o Fundeb, em especial para a remuneração digna dos profissionais da educação.

No âmbito dos estados, do Distrito Federal e dos municípios, a proposta seria a de generalizar a vinculação de $30 \%$ dos impostos e transferências para a MDE - já praticada por oito estados e muitos municípios. Desses $30 \%, 25 \%$ ficariam adstritos à educação básica pública (continuando a redistribuição de 20\% para o Fundeb) e $5 \%$ poderiam ser destinados a qualquer nível, etapa ou modalidade do ensino, a critério dos planos estaduais e municipais de educação. Para aumentar a arrecadação de ICMS, seria revista a imunidade constitucional (oriunda da Lei Kandir) dos produtos exportados, o que tem reduzido drasticamente a capacidade de receita de muitos estados e seus municípios. Basta lembrar o caso do Pará, talvez o território mais rico do País: exportados o minério, a madeira, os grãos e a carne sem pagamento de impostos, a União precisa lhe transferir mais de $R \$$ 2 bilhões a título de complementação do Fundeb...

Nos municípios seriam potenciados os impostos que derivam da capacidade contributiva dos seus cidadãos e empresas: ITR, IPTU, ISS e IRRF dos servidores públicos. Numa democracia, o princípio que funda a presença do estado nas políticas sociais é o dos direitos sociais (educação, saúde, transporte, previdência, etc), garantidos pela canalização de recursos financeiros baseados na capacidade contributiva de pessoas físicas

e jurídicas. A humanidade evoluiu das práticas predatórias e individualistas para o princípio universalmente 
aceito de convivência: "a cada um segundo suas necessidades, cobrando de cada um segundo sua capacidade". É uma irresponsabilidade fiscal convivermos com fortunas de pessoas e empresas que não são taxadas proporcionalmente à sua capacidade - não só pagam um IR desprezível, não só não são cobrados pelo Imposto sobre Grandes Fortunas, como não são alcançados pelos tributos patrimoniais, como o ITR e IPTU. Na vizinhança do MEC, no Distrito Federal, mansões pagam IPTU em valores subestimados e os professores têm parte de seus salários providos pelo "Fundo Constitucional" do DF, oriundo de tributos que gravam os estados e municípios de todo o país. O que dizer da prática anti-cidadã de cartórios que sub-valorizam casas e terrenos para reduzir o valor do ITBI e a alíquota de 4\% do Imposto sobre Heranças (ITBDCM), que nos países avançados é de mais de $40 \%$ e representa a contribuição dos que acumularam riquezas para as novas gerações?

Concluindo esta seção do artigo: só chegaremos a 10\% do PIB com mais arrecadação. Ou, ironicamente, com a diminuição do ritmo de crescimento e com maior inflação. Imagino que ninguém aposta nessas tragédias...

\section{Breve análise da Meta 20 e das estratégias de financiamento no PNE}

É fundamental partirmos do texto da Meta e das doze estratégias:

Meta 20. Ampliar o investimento público em educação pública de forma a atingir, no mínimo, o patamar de 7\% do PIB do País no quinto ano de vigência desta Lei e, no mínimo, o equivalente a $10 \%$ do PIB no final do decênio.

Estratégias

20.1) garantir fontes de financiamento permanentes e sustentáveis para todos os níveis, etapas e modalidades da educação básica, observando-se as políticas de colaboração entre os entes federados, em especial as decorrentes do art. 60 do Ato das Disposições Constitucionais Transitórias e do $\$ 1^{\circ}$ do art. 75 da Lei $n^{\circ} 9.394$, de 20 de dezembro de 1996, que tratam da capacidade de atendimento e do esforço fiscal de cada ente federado, com vistas a atender suas demandas educacionais à luz do padrão de qualidade nacional;

20.2) aperfeiçoar e ampliar os mecanismos de acompanhamento da arrecadação da contribuição do Salário Educação;

20.3) destinar à manutenção e desenvolvimento do ensino, em acréscimo aos recursos vinculados nos termos do art. 212 da Constituição Federal, na forma de lei específica, a parcela da participação no resultado ou da compensação financeira pela exploração de petróleo e gás natura e outros recursos, com a finalidade do cumprimento da meta prevista no inciso VI do caput do art. 214 da Constituição Federal;

20.4) fortalecer os mecanismos e os instrumentos que assegurem, nos termos do parágrafo único do art. 48 da Lei Complementar $n^{\circ}$ 101, de 4 de maio de 2000, a transparência e o controle social na utilização dos recursos públicos aplicados em educação, especialmente a realização de audiências públicas, a criação de portrais eletrônicos de transparência e a capacitação de membros dos conselhos de acompanhamento e controle social do Fundeb, com a colaboração entre o Ministério da Educação, as Secretarias de Educação dos Estados e dos Municípios e os Tribunais de Contas da União, dos Estados e dos Municípios;

20.5) desenvolver, por meio do Instituto Nacional de Estudos e Pesquisas Educacionais Anísio Teixeira INEP, estudos e acompanhamento regular dos investimentos e custos por aluno da educação básica e superior pública, em todas as suas etapas e modalidades;

20.6) no prazo de dois anos da vigência deste PNE, será implantado o Custo-Aluno-Qualidade inicial - CAQi, referenciado no conjunto de padrões mínimos estabelecidos na legislação educacional e cujo financiamento será calculado com base nos respectivos insumos indispensáveis ao processo de ensino-aprendizagem e será progressivamente reajustado até a implementação plena do Custo-Aluno-Qualidade - CAQ;

20.7) implementar o Custo-Aluno-Qualidade - CAQ, como parâmetro para o financiamento da educação de todas as etapas e modalidades da educação básica, a partir do cálculo e do acompanhamento regular dos indicadores de gastos educacionais com investimentos em qualificação e remuneração do pessoal docente e dos 
demais profissionais da educação pública, em aquisição, manutenção, construção e conservação de instalações e equipamentos necessários ao ensino e em aquisição de material didático-escolar, alimentação e transporte escolar;

20.8) o CAQ será definido no prazo de três anos e será continuamente ajustado, com base em metodologia formulada pelo Ministério da Educação - MEC, e acompanhado pelo Fórum Nacional de Educação, pelo Conselho Nacional de Educação - CNE e pelas Comissões de Educação da Câmara dos Deputados e de Educação, Cultura e Esportes do Senado Federal;

20.9) regulamentar o parágrafo único do art. 23 da Constituição Federal, no prazo de dois anos, por lei complementar, de forma a estabelecer as normas de cooperação entre a União, os Estados, o Distrito Federal e os Municípios, em matéria educacional, e a articulação do sistema nacional de educação em regime de colaboração, com equilíbrio na repartição das responsabilidades e dos recursos e efetivo cumprimento das funções redistributiva e supletiva da União no combate às desigualdades educacionais regionais, com especial atenção às regiões Norte e Nordeste;

20.10) caberá à União, na forma da lei, a complementação de recursos financeiros a todos os Estados, ao Distrito Federal e aos Munic ípios que não conseguirem atingir o valor do CAQi e, posteriormente, do CAQ;

20.11) aprovar, no prazo de um ano, Lei de Responsabilidade Educacional, assegurando padrão de qualidade na educação básica, em cada sistema e rede de ensino, aferida pelo processo de metas de qualidade aferidas por institutos oficiais de avaliações educacionais;

20.12) de finir critérios para distribuição dos recursos adicionais dirigidos ao longo do decênio, que considerem a equalização das oportunidades educacionais, a vulnerabilidade socioeconômica e o compromisso técnico e de gestão do sistema de ensino, a serem pactuados na instância prevista no $§ 5^{\circ}$ do art. $7^{\circ}$ desta Lei.

Celebremos, em primeiro lugar, o texto da Meta 20. Além de se preservar o sentido original do art. 214, do objetivo de se pactuar o percentual de recursos públicos investidos em educação pública, são fixadas duas metas ao longo do decênio: $7 \%$ e 10\% no quinto e décimo ano, respectivamente. Embora não tenha ficado claro, nas estratégias, de que percentual se parte - poderia ser o de 5,6\% em 2013? - é importante ter a meta intermediária mais próxima num valor menos ousado, inclusive para dar tempo a mudanças legislativas e de gestão necessárias para se atingir as metas.

Uma das mudanças legislativas diz respeito à uniformização dos percentuais de impostos vinculados à MDE - se possível na perspectiva proposta neste artigo, de 30\% para a educação, sendo 25\% para a educação básica e $20 \%$ para o Fundeb.

Mudança urgente que afeta a capacidade de investimento da União em educação é uma proposta de emenda à Constituição para desvincular das principais contribuições sociais, gradativamente, até 10\% de suas receitas para a MDE, se possível destinados ao Fundeb e à viabilização do Piso Salarial Nacional dos Profissionais da Educação, segundo o art. 206 da Constituição.

Importante também será a definição de uma política de financiamento para as Universidades Federais e os Institutos Federais de Educação, Ciência e Tecnologia. Podemos, inclusive, resgatar a ideia - válida também para as instituições estaduais de educação superior - de se criar uma contribuição social semelhante à do Salário Educação, que não gravasse empresas, mas os concluintes de cursos superiores gratuitos, em valores discretos mas contínuos, proporcionais a suas rendas anuais aferidas pela Receita Federal. Há dez anos, calculei que um adicional ao IR, de 3\% sobre a renda bruta, seria suficiente para duplicar as receitas que hoje sustentam as universidades federais e estaduais. Com o extraordinário incremento de concluintes de cursos superiores gratuitos no último decênio, criar-se-ia um círculo virtuoso capaz de reverter nossa situação de inferioridade em termos de atendimento na educação superior no conjunto de países da América Latina.

A introdução dos conceitos do CAQ e do CAQi exige, a curto prazo, a reformulação de dispositivos do Fundeb que atualmente regulam o valor mínimo anual por aluno e, consequentemente, o quantitativo necessário para a 
complementação da União. Na verdade, o INEP e outras instituições do MEC terão a responsabilidade de fixar valores - inclusive variados entre escolas de jornada integral e turno parcial - que, devidamente aplicados aos orçamentos da União, dos estados, do DF e dos municípios, revolucionarão o financiamento. Parece-me urgente que se transforme a atual Secretaria de Articulação dos Sistemas de Ensino (SASE) numa Secretaria de Planejamento Articulado do Sistema Nacional de Educação, a ser dotada de técnicos de alto nível com formação e experiência multidisciplinar, para dar conta da complexidade da nova proposta a ser implementada a partir de 2016 (ou 2017?).

A maior dificuldade de implementação da Meta 20, entretanto, tem a ver com dois procedimentos urgentes, contra os quais pesam consideráveis obstáculos.

O primeiro é o da elaboração ou adequação dos Planos Estaduais e Municipais de Educação, para o que a lei deu prazo até dia 25 de junho de 2015, conforme seu artigo $8^{\circ}$. Os PEE e PME abrangem $90 \%$ dos 50 milhões de atendidos na educação básica e superior; e cerca de 90\% dos que se deve atender, principalmente na educação infantil, na EJA e na educação profissional. Ora, só chegaremos a 7\% do PIB do país em 2019 se planejarmos investir, em cada estado, no DF e em cada município, 7\% ou mais do PIB de cada ente federado. Exemplificando: o Acre já investe mais de 10\% de seu PIB em educação, somando os gastos ali feitos pela União, governo estadual e governos municipais. Ou seja, ele já chegou a 2023. Mas tem pouco peso no resultado geral do País, por sua pequena população. Mas São Paulo investe menos de 5\% de seu PIB. O mesmo acontece com o Distrito Federal. Ora, na conta da composição do PIB-Brasil, São Paulo + DF representam mais de 20\%, enquanto o Acre não chega a 0,5\%. Em outras palavras - os 7\% e 10\% do PIB não são um ato de voluntarismo do Governo Federal, mas um esforço do país como um todo. Não desanimemos...

O segundo procedimento tem a ver com um conflito de legislação que está impedindo o avanço do atendimento à demanda por educação e a melhoria dos salários dos profissionais da educação. De um lado, o Fundeb exige que pelo menos $60 \%$ de sua receita, em cada estado e município, sejam destinados ao pagamento dos professores em exercício. De outro, a Lei de Responsabilidade Fiscal impede que se ultrapasse a 49\% e 54\%, respectivamente, em gastos com pessoal. Ora, educação é uma política pública que responde a direitos constitucionais, inalienáveis e se caracteriza pela massiva concentração de gastos com pessoal - professores, gestores e funcionários das escolas, que consomem entre $80 \%$ e $90 \%$ de suas receitas. A solução tem sido não abrir mais vagas, não dar aumentos de salários, não contratar mais professores - o que redunda em precarização, terceirização e privatização. Está na hora de se rasgar a fantasia. O Ministério da Fazenda, o Ministério da Educação, o Congresso Nacional, o Tribunal de Contas da União e o Poder Judiciário precisam se entender com urgência. Senão, o incrível vai acontecer: o Ministério da Educação, as Secretarias de Educação com as burras repletas de reais, tendo que devolver os recursos ou gastá-los nos prédios das escolas, em pisos de mármores e vasos de ouro.

\section{Referências}

BRASIL. Constituição Federal de 1988. Disponível em http://www.planalto.gov.br/ccivil_03/constituicao/ constituicaocompilado.htm

. Lei de Diretrizes e Bases da Educação Nacional, Lei Federal 9.394/96. Disponível em http://www. planalto.gov.br/ccivil_03/leis/19394.htm.

Lei de Responsabilidade Fiscal, Lei Complementar 101/2000. Disponível em http://www.planalto.gov. br/ccivil_03/leis/lcp/lcp101.htm.

Lei do Plano Nacional de Educação, Lei Federal 13.0005/14. Disponível em http://www.planalto.gov. br/ccivil_03/_Ato2011-2014/2014/Lei/L13005.htm

Recebido em Setembro de 2014 - Aprovado em Novembro de 2014 


\title{
O Custo Aluno-Qualidade Inicial como proposta de justiça federativa no PNE: Um primeiro passo rumo à educação pública de qualidade no Brasil
}

The Quality Student Initial Cost as a federal justice proposed in the PNE: a first step towards the quality of public education in Brazil

El Costo Inicial Estudiante-Calidad como una proposta de justicia federativa en el PNE: un primer paso hacia la calidad de la educación pública en Brasil

Daniel Cara'

\section{Resumo}

Este artigo apresenta o Custo Aluno-Qualidade Inicial (CAQi) como um instrumento voltado a equilibrar o federalismo brasileiro no que se refere à educação básica, e discute como ele se constitui em um dos principais pilares do novo PNE. Para tanto, o trabalho contextualiza o federalismo brasileiro, localizando os problemas da política educacional em meio às desigualdades regionais geradas ou potencializadas pelo modelo de organização do estado nacional brasileiro. O artigo ainda discute os marcos legais e a localização do CAQi neste cenário, e, com isto, advoga-o como uma ferramenta que garante o padrão mínimo de qualidade definido na Constituição Federal. Por fim, o texto apresenta como a questão do CAQi figura no PNE, assim como evidencia como se dará a transição entre o CAQi e o Custo Aluno-Qualidade (CAQ).

Palavras-chave: Custo Aluno-Qualidade Inicial; PNE; Financiamento da Educação; Justiça federativa.

\begin{abstract}
:
This paper presents the Initial Quality Student Cost (CAQi) as an instrument aimed to balance the Brazilian federalism and its effects on the basic education, and discusses how it is one of the main pillars of the new PNE. Therefore, the work contextualizes the Brazilian federalism, locating the problems of education policy in the context of regional inequalities generated or enhanced by Brazilian national state organizational model. The article also discusses the legal framework and the location of CAQi in this scenario, and, thus, advocates it as a tool that guarantees the quality minimum standard defined in the Federal Constitution. Finally, the text shows how the issue of CAQi figure in the PNE, as well as evidences how will be the transition between CAQi and the Quality Student Cost (CAQ).
\end{abstract}

Keywords: Initial Quality Student Cost; PNE; Education financing; Federative justice.

1 Doutorando na Faculdade de Educação da Universidade de São Paulo (USP), mestre em ciência política (USP), coordenador geral da Campanha Nacional pelo Direito à Educação, membro titular do Fórum Nacional de Educação (FNE) e colunista do canal "Educação" do portal UOL. E-mail: tojeira.cara@gmail.com 


\section{Resumen:}

Este trabajo presenta el Costo Estudiante-Calidad Inicial (CAQi) como un instrumento destinado a equilibrar el federalismo brasileño con respecto a la educación básica, y se analiza la forma en que el CAQi es uno de los principales pilares del nuevo PNE. Por lo tanto, el trabajo contextualiza el federalismo brasileño, la localización de los problemas de la política educativa en medio a las desigualdades regionales generadas o majoradas por el modelo de organización del Estado nacional brasileño. El artículo también analiza el marco legal y la ubicación de CAQi en este escenario, y, por lo tanto, lo defiende como una herramienta que garantiza el estándar mínimo de calidad definido en la Constitución Federal. Por último, el texto muestra cómo CAQi está puesto en el PNE, así como demostra como se dará la transición entre CAQi y el costo-calidad para Estudiantes (CAQ).

Palabras-clave: Costo Estudiante-Calidad Inicial; PNE; Financiamiento de la educación; Justicia Federativa.

\section{Introdução}

A implementação do Custo Aluno-Qualidade Inicial (CAQi) esteve entre os temas mais debatidos pela opinião pública, sociedade civil, pesquisadores, parlamentares e representantes do Poder Executivo Federal no processo de tramitação do novo Plano Nacional de Educação (PNE) no Congresso Nacional.

Este artigo apresenta o mecanismo do Custo Aluno-Qualidade Inicial (CAQi), criado e calculado pela Campanha Nacional pelo Direito à Educação, como um instrumento capaz de tornar mais equilibrado e eficaz o federalismo brasileiro no tocante à oferta de matrículas em educação básica, sendo um dos principais pilares do novo PNE - estabelecido na forma da Lei 13.005/2014.

O objetivo do CAQi é materializar um padrão mínimo de qualidade justo, capaz de promover uma educação que visa "o pleno desenvolvimento da pessoa, seu preparo para o exercício da cidadania e sua qualificação para o trabalho", tal como determina o caput do Art. 205 da Constituição Federal - CF.

Além disso, o CAQi busca garantir a "igualdade de condições para o acesso e permanência na escola", princípio asseverado no primeiro inciso do Art. 206 da CF. Em outras palavras, o que se quer com sua implementação é dar condições para que seja ofertada uma educação plural, emancipadora e justa para todos os brasileiros e brasileiras. Enfim, a educação necessária para um Brasil justo e próspero.

O texto também mostra como a questão do CAQi figura no plano, bem como se dará a transição entre o CAQi e o Custo Aluno-Qualidade.

\section{Contextualização: o federalismo brasileiro, as políticas sociais e a política de educação}

No Brasil, ao longo da história, o debate educacional tem dado crescente destaque à questão federativa. O motivo é simples: o pacto federativo é um dos fatores mais relevantes para o resultado das políticas educacionais (CURY, 2006), pois acaba determinando a organização e a gestão do Estado, gerando enorme impacto na estruturação administrativa e política dos governos e na forma como eles respondem² aos cidadãos (ABRUCIO, 2010).

Para analisar os resultados do federalismo brasileiro na implementação e gestão de políticas sociais, Arretche (2004) realiza um extenso levantamento bibliográfico de política internacional comparada. Segundo as pesquisas sistematizadas pela autora, os estados federativos ao redor do mundo são encarados como propensos a produzir níveis comparativamente mais baixos de gasto social em relação a países unitários, bem como menor abrangência e cobertura dos programas sociais. Tendem, ainda, a tornar mais difíceis os problemas de coordenação dos objetivos das políticas, gerando superposição de competências e competição 
entre os diferentes níveis de governo, dada a relação negativa entre a dispersão da autoridade política e a consistência interna das decisões coletivas. Adicionalmente, em estados federativos, as políticas nacionais tendem a se caracterizar por um mínimo denominador comum, necessário para amenizar o impacto das assimetrias existentes nas federações.

É ocioso frisar que qualquer semelhança com a realidade brasileira não é mera coincidência. As conclusões listadas por Arretche (2004) acabam por compor o elenco de desafios a serem considerados e tratados por todos os estados federados, ainda que em graus diferentes e a partir de pontos de partida distintos.

As heterogeneidades, as trajetórias históricas e o legado cultural de cada país impedem a elaboração de uma fórmula específica que oriente os países federados a estabelecer suas instituições (ABRUCIO, 2010). Contudo, se não é possível implementar um desenho institucional ótimo e universal para as federações, ao menos é conhecido o fator determinante do sucesso ou insucesso de qualquer modelo federativo: a capacidade de coordenação entre os entes federados para a realização de políticas públicas que visem à superação de desigualdades diversas e à correção de assimetrias intrafederativas. Em outras palavras, a qualidade de uma federação depende de sua capacidade de compatibilizar autonomia e interdependência entre os entes federados, necessariamente por meio de direitos e deveres bem definidos, além do estabelecimento de normas e arenas institucionais que, respectivamente, orientem e arbitrem medidas administrativas adequadas e legítimas para o conjunto dos entes federados.

Como as assimetrias intrafederativas, ou simplesmente as desigualdades, é um traço comum de todas as federações, a coordenação entre os entes federados exige o estabelecimento de padrões nacionais de qualidade para as políticas públicas, até mesmo como um esforço de legitimação das iniciativas dos governos federais. Como é muito difícil universalizar em um mesmo território a qualidade da oferta de um serviço público, recorre-se aos padrões mínimos de qualidade, ou ao "mínimo denominador comum" das políticas nacionais destacado pela investigação bibliográfica de Arretche (2004).

Condizente com essa lógica, quando determinou que sua proposta de Custo Aluno-Qualidade (CAQ) era inicial (CAQi), a Campanha Nacional pelo Direito à Educação buscou materializar o padrão mínimo de qualidade da oferta de educação básica no Brasil. Portanto, o CAQi representa apenas um primeiro passo, um ponto de partida, e não pode ser tratado como um patamar suficiente de qualidade da educação, em que pese o fato de que o Brasil esteja distante de concretizá-lo.

OCAQ, por sua vez, representa uma tentativa de superação desse padrão mínimo de qualidade materializado no CAQi, aproximando o Brasil do padrão de investimento praticado pelos países mais desenvolvidos em termos educacionais.

\section{O federalismo brasileiro e a educação}

No caso da educação, há três mecanismos constitucionais que, sendo adequadamente regulamentados e bem articulados entre si, podem garantir uma profícua coordenação federativa, colaborando para o estabelecimento de um modelo de "federalismo cooperativo" no Brasil, tal como propõe Abrucio (2010).

A primeira tarefa para a emergência de um pacto cooperativo seria regulamentar o caput do parágrafo único do art. 23 da CF, que trata da cooperação entre os entes federados.

Art. 23. É competência comum da União, dos Estados, do Distrito Federal e dos Municípios:

$[\ldots]$

V - proporcionar os meios de acesso à cultura, à educação e à ciência;

$[\ldots]$

Parágrafo único. Leis complementares fixarão normas para a cooperação entre a União e os Estados, o Distrito Federal e os Municípios, tendo em vista 0 equilíbrio do desenvolvimento e do bem-estar em âmbito nacional. (Redação dada pela Emenda Constitucional n 53 , de 2006) (grifo nosso). 
A segunda tarefa seria a regulamentação do art. 211 da CF, que, aliás, integra o capítulo da educação da Carta Magna e evidencia a necessidade de materialização do padrão mínimo de qualidade.

Art. 211. A União, os Estados, o Distrito Federal e os Municípios organizarão em regime de colaboração seus sistemas de ensino.

$\S 1^{0} \mathbf{A}$ União organizará o sistema federal de ensino e 0 dos Territórios, financiará as instituições de ensino públicas federais e exercerá, em matéria educacional, função redistributiva e supletiva, de forma a garantir equalização de oportunidades educacionais e padrão mínimo de qualidade do ensino mediante assistência técnica e financeira aos Estados, ao Distrito Federal e aos Municípios; (Redação dada pela Emenda Constitucional $n^{0}$ 14, de 1996).

$\S 2^{\circ}$ Os Municípios atuarão prioritariamente no ensino fundamental e na educação infantil. (Redação dada pela Emenda Constitucional $\mathrm{n}^{0} 14$, de 1996)

$\S 3^{\circ}$ Os Estados e o Distrito Federal atuarão prioritariamente no ensino fundamental e médio. [...] (grifo nosso).

A terceira e última tarefa seria estabelecer o Sistema Nacional de Educação (SNE), disposto no caput do art. 214 da CF. 0 SNE deve ser fruto da síntese da cooperação federativa entre os entes federados (art. 23, parágrafo único) e o regime de colaboração entre os sistemas de ensino (art. 211). Reza a CF que o instrumento legal que articula o SNE é, precisamente, o Plano Nacional de Educação (PNE).

Art. 214. A lei estabelecerá o plano nacional de educação, de duração decenal, com o objetivo de articular o sistema nacional de educação em regime de colaboração e definir diretrizes, objetivos, metas e estratégias de implementação para assegurar a manutenção e desenvolvimento do ensino em seus diversos níveis, etapas e modalidades por meio de ações integradas dos poderes públicos das diferentes esferas federativas [...] (Redação dada pela Emenda Constitucional nº 59, de 2009) (grifo nosso).

Embora o texto da CF apresente uma demanda clara, até o momento, nenhuma autoridade política, no geral, ou qualquer ministro da Educação, em particular, soube ou quis convocar e liderar a agenda para regulamentar a cooperação federativa e o regime de colaboração (CARA, 2012), condição obrigatória para o estabelecimento do SNE. Contudo, a importância do tema levou as comissões organizadoras das três conferências educacionais empreendidas desde 2008 - Conferência Nacional de Educação Básica (Coneb-2008), I Conferência Nacional de Educação (Conae-2010) e II Conae (2014) - a enfatizar a construção do SNE como principal desafio a ser superado para o sucesso das políticas públicas educacionais.

\section{Desafios para a implantação do SNE}

A necessidade de estabelecimento do SNE, que deve ser articulado pelo PNE segundo o Art. 214 da CF, advém das inúmeras desigualdades verificadas na República brasileira, continuamente retroalimentadas pela falta de regulamentação dos mecanismos de equilíbrio federativo que integram a Carta Magna, o que acaba por prejudicar demasiadamente a realização das políticas e, consequentemente, a consagração dos direitos sociais, inclusive o direito à educação.

É possível elencar três grandes categorias de desigualdades: a desigualdade regional, a desigualdade federativa horizontal e a desigualdade federativa vertical.

\section{A desigualdade regional}

No tocante a fatores federativos, as desigualdades mais conhecidas no Brasil são as regionais. O Gráfico 1 mostra a desigualdade regional na participação do Produto Interno Bruto (PIB) brasileiro, retratando a flagrante concentração de atividade econômica no Sudeste, desde 1939. 


\section{Gráfico 1 - Participação (em \%) do PIB regional no PIB brasileiro.}

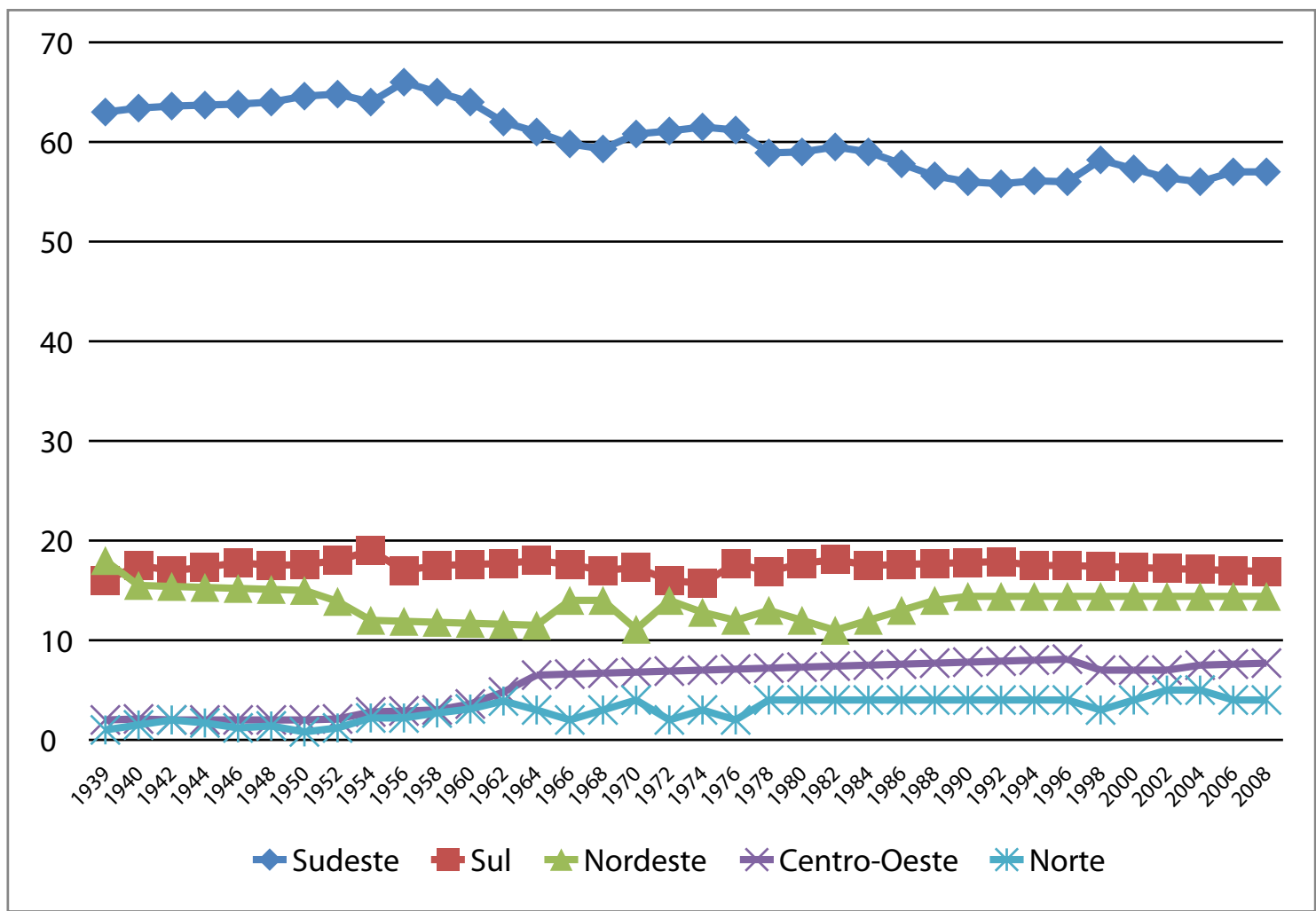

Fonte: Adaptado de Siafi (2008).

\section{A desigualdade federativa horizontal}

Além das desigualdades regionais, há as desigualdades entre os estados, mesmo entre aqueles localizados em uma mesma região e também entre os municípios - inclusive, em relação a cidades localizadas em estados diferentes ou em um mesmo estado. Essa realidade compõe uma espécie de desigualdade federativa horizontal, ou seja, manifesta entre entes subnacionais do mesmo tipo. Em outras palavras, essa categoria compreende as desigualdades entre os estados como pares e também as assimetrias verificadas no conjunto dos municípios entre si.

Em dezembro de 2013, o Instituto Brasileiro de Geografia e Estatística (IBGE) divulgou o estudo "Perfil dos Municípios Brasileiros - 2011". Os resultados da pesquisa demonstram que a geração de riqueza permanece extremamente concentrada no País. Apenas três municípios foram responsáveis por um quinto do PIB brasileiro em 2011, o equivalente a 20,6\% de toda a geração de renda nacional. São eles: São Paulo, Rio de Janeiro e Brasília ${ }^{3}$. Os três primeiros são seguidos por Curitiba, Belo Horizonte e Manaus. O mesmo resultado foi verificado em edição similar da pesquisa, que analisou o ano de 2010. A ordem de importância na geração de riqueza permanece a mesma desde 2008.

Juntos, os seis maiores geradores de riquezas foram responsáveis por $25 \%$ do PIB do Brasil e concentram 13,7\% da população brasileira. Segundo o IBGE - e graças à Zona Franca de Manaus -, com exceção da capital amazonense, onde há equilíbrio entre a participação da indústria de transformação e dos serviços, os outros cinco municípios são concentradores da atividade de "serviços, intermediação financeira, comércio e administração pública". 
Em 2011, apenas São Paulo gerou 11,5\% de toda a renda do País. O Rio de Janeiro foi responsável por uma fatia de 5,1\% do PIB nacional, enquanto Brasília ficou com 4,0\%; Curitiba, com 1,4\%; Belo Horizonte, 1,3\%; e Manaus, 1,0\%. Naquele ano, o país era dividido em 5.565 municípios.

Pela pesquisa também é possível demonstrar as desigualdades entre os estados: São Paulo emplacou nove municípios na lista dos 25 maiores geradores de renda do País. Além da capital paulista, os outros grandes geradores de renda do estado foram: Guarulhos (1,05\% do PIB), Campinas (0,98\%), Osasco (0,95\%), São Bernardo do Campo (0,88\%), Barueri (0,77\%), Santos (0,76\%), São José dos Campos (0,61\%) e Jundiaí (0,53\%). Juntos, os nove municípios paulistas foram responsáveis por $18,04 \%$ do PIB brasileiro.

No conjunto dos 50 maiores geradores de renda, há 15 municípios paulistas, que produziram o equivalente a uma fatia de $20,19 \%$ do PIB. Além dos citados acima estão ainda Ribeirão Preto $(0,45 \%)$, Sorocaba $(0,43 \%)$, Santo André (0,43\%), Diadema (0,28\%), São Caetano do Sul (0,28\%) e Piracicaba (0,28\%).

Já na lista dos cem principais responsáveis pelo PIB de 2011, a participação paulista sobe para 31 municípios, com a presença de Louveira (0,26\%), Taubaté (0,24\%), São José do Rio Preto (0,23\%), Mogi das Cruzes $(0,23 \%)$, Paulínia (0,20\%), Bauru (0,19\%), Sumaré $(0,19 \%)$, Mauá $(0,18 \%)$, Limeira $(0,18 \%)$, Vinhedo $(0,18 \%)$, Cotia $(0,17 \%)$, Americana (0,17\%), Hortolândia (0,16\%), Itapevi (0,15\%), Indaiatuba $(0,14 \%)$ e Cajamar $(0,14 \%)$. Juntos, os 31 municípios paulistas aqui listados responderam por quase um quarto do PIB nacional, o equivalente a $23,2 \%$.

Além disso, a partir dos dados do estudo do IBGE, é possível verificar que a grande maioria dos municípios brasileiros tem gastos públicos maiores do que o que a sua economia gera de tributos, somando as arrecadações municipais, estaduais e federais. No total, apenas 417 cidades brasileiras geram mais dinheiro público do que gastos. E quando se analisa os dados por unidade da federação, é possível entender melhor o perfil dos municípios deficitários e as desigualdades horizontais: oito estados nordestinos estão entre os dez com maior defasagem entre arrecadação municipal e os gastos públicos de seus municípios. Os outros dois são Pará e Rondônia, localizados na Região Norte.

\section{A desigualdade federativa vertical}

Por último, há a desigualdade vertical, sendo esta a menos conhecida, mas certamente a mais representativa em termos federativos globais.

Segundo dados de 2010 do Conselho de Desenvolvimento Econômico e Social da Presidência da República, a União retém 57,1\% dos recursos disponíveis arrecadados, sobrando 24,6\% para os 26 Estados e para 0 Distrito Federal e apenas 18,3\% para os mais de 5.000 municípios. Contudo, conforme dados de 2009 do Inep (Instituto Nacional de Estudos e Pesquisas Educacionais Anísio Teixeira), órgão vinculado ao MEC (Ministério da Educação), a cada $\mathrm{R} \$ 1$ público investido em políticas educacionais naquele ano, Estados e 0 Distrito Federal despenderam $R \$ 0,41$, os municípios investiram $R \$ 0,39$ e a União colaborou com só $R \$ 0,20$ (CARA, 2012a).

O aspecto dramático das desigualdades federativas brasileiras, em especial a desigualdade vertical, é que as políticas sociais, como resultado da lógica de municipalização, alicerçada pela CF vigente, ficam essencialmente a cargo dos municípios, seja por responsabilização constitucional ou devido à pressão do munícipe sobre o prefeito ou prefeita, o que é territorialmente facilitado. O lema do ex-governador paulista André Franco Montoro pode ter se tornado lugar-comum, mas permanece verdadeiro: "Ninguém vive no Estado ou na União. Eles são figuras jurídicas. Nós vivemos nos municípios." Como também é fato que muitos municípios não gozam de condições para dar conta das demandas que lhe são cobradas.

Como os instrumentos para o federalismo cooperativo não foram, ainda, devidamente regulamentados e articulados, além do próprio fato de os municípios serem desiguais entre si e terem menor capacidade de investimento somado do que o conjunto dos estados e a União, as políticas sociais que dependem da ação dos governos locais tendem a enfrentar maior fragilidade orçamentária, resultando em menor cobertura e pior qualidade.

No caso da educação, o prejuízo mais explícito é o da educação infantil, em especial o direito à creche. O motivo, como reza o $\S 2^{\circ}$ do art. 211 da CF, é que cabe ao município atuar "prioritariamente no ensino 
fundamental e na educação infantil." Dito de outro modo, cabe ao ente federado mais frágil, especialmente em termos orçamentários, custear a etapa mais onerosa de toda a educação básica. Cabe ressaltar que, embora a situação do município seja muito mais complexa, diante de sua baixa arrecadação, também não é fácil para os estados arcarem com os custos do ensino médio.

\section{O CAQi como padrão mínimo de qualidade}

Para determinar uma referência de qualidade no investimento em educação, em 2007, a Campanha Nacional pelo Direito à Educação publicou o livro Custo Aluno-Qualidade Inicial: rumo à educação pública de qualidade no Brasil (CARREIRA; PINTO, 2007), resultado de um estudo inédito conduzido desde 2002.

A partir de insumos como número médio de alunos por turma, pagamento do piso nacional salarial do magistério, política de carreira e de formação continuada aos profissionais da educação, bibliotecas e salas de leitura, laboratórios de ciências, laboratórios de informática, quadras poliesportiva cobertas, brinquedotecas para todas as creches, pré-escolas e escolas dos anos iniciais do ensino fundamental e garantia de recursos para o desenvolvimento de projetos pedagógicos - o Custo Aluno-Qualidade Inicial (CAQi) aponta quanto deve ser investido anualmente por aluno de cada etapa da educação básica para que o Brasil comece a oferecer uma educação (e uma escola) pública com um padrão mínimo de qualidade, materializando a demanda disposta no $\S 1^{\circ}$ do art. 211 da CF, que obriga uma participação mais efetiva da União.

Em termos práticos, o CAQi propõe uma inversão da lógica que rege hoje a definição dos orçamentos públicos para a educação no País, pois parte do que é necessário para garantir a educação com um padrão mínimo de qualidade e não do que está disponível no orçamento. O estudo do CAQi foi a base da Nota Técnica "Por que 7\% do PIB para a educação é pouco? Cálculo dos investimentos adicionais necessários para o novo PNE garantir um padrão mínimo de qualidade" (CAMPANHA NACIONAL PELO DIREITO À EDUCAÇÃO, 2011)4, até o momento o principal documento produzido pela sociedade civil para questionar o patamar de investimento de $7 \%$ do PIB, proposto pelo MEC, como meta de financiamento do novo Plano Nacional de Educação (PNE). Essa Nota Técnica foi analisada pelo Ipea em três publicações: no Comunicado nº 124 (2011), no livro Brasil em desenvolvimento 2011: Estado, Planejamento e Políticas Públicas (2012a) e no Políticas Sociais: acompanhamento e análise (2012b).

\section{O CAQi e o marco legal brasileiro}

Historicamente, a participação da União no financiamento das políticas sociais está muito aquém de seu poder arrecadatório e de sua capacidade de investimento. Relembrando uma citação anterior, segundo dados do Inep, em 2009, a cada $R$ \$ 1 público investido em educação pública, o governo federal aplicou apenas $R$ \$ 0,20. Em 2012 a situação piorou. Novamente, conforme dados do Inep, de cada R\$1 público investido em educação pública, o governo federal colocou $\mathrm{R} \$ 0,18$. Os estados e o Distrito Federal aplicaram, em conjunto, $R \$ 0,40$. Já os municípios investiram $R \$ 0,42 .{ }^{5}$

Ou seja, o ente federado que mais arrecada, possuidor de mais da metade da receita tributária líquida, é aquele que menos contribui com as políticas públicas educacionais. Inversamente, o que menos arrecada, é o que mais investe em educação.

Sendo problema antigo, o tema é tratado objetivamente no $\S 1^{\circ}$ do art. 211 da CF: a União deve exercer, em matéria educacional, "função redistributiva e supletiva, de forma a garantir equalização de oportunidades

4 A referida Nota Técnica foi produzida por mim e por Luiz Araújo, doutor em educação pela Faculdade de Educação da Universidade de São Paulo e expresidente do Instituto de Políticas Educacionais Anísio Teixeira (Inep).

5 Os dados de 2012 só foram divulgados após requerimento de informação apresentado pelo Senador Randolfe Rodrigues (Psol-AP). 
educacionais e padrão mínimo de qualidade do ensino mediante assistência técnica e financeira aos estados, ao Distrito Federal e aos municípios."

\section{O legislador e o padrão mínimo de qualidade}

Ciente de que as desigualdades existentes na federação brasileira são herança, entre outros fatores, do desenvolvimento assimétrico da economia nas diversas regiões e estados do país, e que a União arrecada muito mais do que os demais entes federados, o legislador estabeleceu que caberia a ela o papel de diminuir as desigualdades federativas. Tal ação deveria ser feita via redistribuição de recursos, por meio de medidas como foi o Fundef ${ }^{6}$ e é atualmente o Fundeb ${ }^{7}$, ambos no caso da educação.

Como as desigualdades são muito gritantes e os custos das regiões brasileiras são díspares, o legislador determinou que a função supletiva e redistributiva da União deve ter como pressuposto um padrão mínimo de qualidade nacional $^{8}$, como um atributo de cidadania e justiça federativa. Em outras palavras, independentemente de onde esteja residindo a cidadã ou o cidadão, toda brasileira ou brasileiro deve ter assegurado seu direito à educação pública com base em um patamar básico de qualidade.

Essa referência pretende reduzir as desigualdades nacionais, tal como dispõe o inciso I do Art. 206 da Constituição Federal: "Art. 206. O ensino será ministrado com base nos seguintes princípios: I - igualdade de condições para o acesso e permanência na escola; [...] (grifo nosso)".

Como dito anteriormente, foi como um exercício de definição objetiva do padrão mínimo de qualidade na educação básica que a Campanha Nacional pelo Direito à Educação coordenou os esforços coletivos que culminaram na formulação do mecanismo do CAQi (Custo Aluno-Qualidade Inicial). Pragmaticamente, a Campanha também buscou mensurar os custos da demanda gerada pelo inciso IX do Art. $4^{\circ}$ da Lei de Diretrizes e Bases da Educação Nacional (LDB, Lei 9.394/1996).

Art. $4^{0} 0$ dever do Estado com educação escolar pública será efetivado mediante a garantia de: (...)

IX - padrões mínimos de qualidade de ensino, definidos como a variedade e quantidade mínimas, por aluno, de insumos indispensáveis ao desenvolvimento do processo de ensino-aprendizagem. (grifo nosso)

Após diversas rodadas de consulta e negociação, que envolveram dezenas de pesquisadores, gestores e servidores públicos, sindicalistas, ativistas, professores e outros educadores, pais e estudantes, a Campanha Nacional pelo Direito à Educação concluiu uma primeira versão do CAQi, expressa concretamente pela a lista e a precificação dos insumos necessários para a garantia do padrão mínimo de qualidade para cada etapa e modalidade da educação básica.

Em 5 de maio de 2010, o Conselho Nacional de Educação (CNE) aprovou o Parecer CNE/CEB n 8, de 2010, que normatiza os padrões mínimos de qualidade da educação básica nacional de acordo com o CAQi. O parecer resulta do Termo de Cooperação firmado entre a Câmara de Educação Básica do CNE e a Campanha Nacional pelo Direito à Educação em 5 de novembro de 2008, o primeiro estabelecido entre o Conselho e uma organização da sociedade civil. Contudo, o parecer aguarda homologação por parte do MEC ${ }^{9}$ desde então.

Aprovado nos documentos finais de todas as conferências de educação, como ferramenta basilar do SNE, a viabilização do CAQi impõe a necessidade de materialização da função redistributiva e supletiva da União na educação básica.

6 Fundef é o Fundo de Manutenção e Desenvolvimento do Ensino Fundamental e de Valorização do Magistério. Foi instituído pela Emenda Constitucional n. ${ }^{0} 14$, de setembro de 1996, e regulamentado pela Lei $n .{ }^{\circ}$ 9.424, de 24 de dezembro do mesmo ano, e pelo Decreto $n^{0} 2.264$, de junho de 1997.

7 Fundeb é o Fundo de Manutenção e Desenvolvimento da Educação Básica e de Valorização dos Profissionais da Educação. Foi criado pela Emenda Constitucional $n^{0}$ 53/2006 e regulamentado pela Lei $n^{0}$ 11.494/2007 e pelo Decreto n ${ }^{0}$ 6.253/2007, em substituição ao Fundef, que vigorou de 1998 a 2006.

80 piso nacional salarial do magistério, regulamentado pela Lei 11.738/2008 é familiar à ideia de padrão mínimo de qualidade ou de "mínimo denominado comum" das políticas nacionais, relembrando Arretche (2004).

9 Poderiam ter homologado o CAQi os ex-ministros Fernando Haddad e Aloizio Mercadante. 
Para mensurar essa medida de justiça federativa, inúmeras metodologias poderiam ser trilhadas. Em Nota Técnica ${ }^{10}$ recente, a Associação Nacional dos Pesquisadores em Financiamento da Educação (Fineduca), optou por calcular a necessidade de participação financeira da União a partir do melhor mecanismo federativo vigente na educação: o Fundeb. Este sistema de 27 fundos estaduais financia toda a educação básica - a creche até o ensino médio, considerando todas as modalidade - e foi construído por meio de forte interação entre o Poder Público e a sociedade civil (MARTINS, 2011) ${ }^{11}$.

Em termos práticos, segundo o ordenamento normativo atual, o CAQi é uma referência comparativa à definição dos valores mínimos do Fundeb, que não correspondem a um padrão mínimo de qualidade. Tanto é assim que menos de $1 \%$ das escolas brasileiras têm infraestrutura mínima segundo os critérios do CAQi (SOARES NETO, 2013), sendo que além da infraestrutura das escolas, o mecanismo considera muitos outros insumos, como remuneração dos profissionais, número de alunos por turma, etc.

Para a realização da estimativa de demanda da participação da União na educação básica, primeiro foi levantado o número de matrículas de cada etapa e modalidade contabilizadas em cada um dos 27 fundos estaduais do Fundeb, conforme o Censo Escolar de 2011. Posteriormente, as matrículas foram multiplicadas pelo valor corrente do CAQi-2012. Os resultados dessa longa operação está sintetizada no Quadro 1.

\section{Quadro 1. Valores de referência do CAQi (2012)}

\begin{tabular}{|c|c|c|}
\hline & Fonte/cálculo & Valor (R\$) \\
\hline Creche (tempo integral) & CAQi & $8.288,28$ \\
\hline Creche (tempo parcial & CAQi + Fundeb* & $5.097,29$ \\
\hline Pré-escola (tempo integral) & CAQi + Fundeb ${ }^{*}$ & $4.171,77$ \\
\hline Pré-escola (tempo parcial) & CAQi & $3.209,05$ \\
\hline Ensino Fundamental Anos Iniciais - Urbano & CAQi & $3.060,29$ \\
\hline Ensino Fundamental Anos Finais - Urbano & CAQi & $2.996,53$ \\
\hline Ensino Fundamental Anos Iniciais - Rural & CAQi & $5.057,98$ \\
\hline Ensino Fundamental Anos finais - Rural & CAQi & $3.867,86$ \\
\hline Ensino Fundamental Tempo Integral & CAQi + Fundeb ${ }^{*}$ & $3.978,38$ \\
\hline Ensino Médio Urbano & CAQi & $3.081,54$ \\
\hline Ensino Médio Rural & CAQi (EF II Rural) & $3.867,86$ \\
\hline Ensino Médio Tempo Integral & CAQi + Fundeb & $3.337,31$ \\
\hline Ensino Médio integrado à Ed. Profissional & CAQi + Fundeb & $3.337,31$ \\
\hline Educação Especial & CAQi & $6.120,50$ \\
\hline Educação de Jovens e Adultos & CAQi & $3.060,29$ \\
\hline EJA (integrada à Educação Profissional) & CAQi + Fundeb & $3.672,35$ \\
\hline Educação Indígena e Quilombola & CAQi (EF I Rural) & $5.057,98$ \\
\hline Creches conveniadas (tempo integral) & CAQi + Fundeb & $7.011,88$ \\
\hline Creches conveniadas (tempo parcial) & CAQi + Fundeb & $5.097,29$ \\
\hline Educação Especial (instituições conveniadas) & CAQi + Fundeb & $6.120,58$ \\
\hline
\end{tabular}

Fonte: Fineduca, 2013.

Obs: * Nesses casos, em que o Parecer CEB/CNE no 8/2010 não estabeleceu um valor para o CAQi, usou-se o valor por aluno do CAQi para a etapa correspondente o fator de ponderação do Fundeb.

Nota: Os valores do CAQi levaram em conta o Parecer CEB/CNE nº 8/2010 e o PIB per capita de 2011 (R\$ 21.252,00).

10 Publicada em setembro de 2013, esta Nota Técnica foi produzida pelo Prof. Dr. José Marcelino Rezende Pinto (USP/Ribeirão Preto e presidente da Fineduca) e contou com a minha colaboração e de Luiz Araújo.

11 Por sua bem-sucedida incidência na construção e regulamentação do Fundeb, a Campanha Nacional pelo Direito à Educação foi agraciada em 2007 com Prêmio Darcy Ribeiro, concedido pela Câmara dos Deputados. 
Em seguida, a Nota Técnica apresenta o cálculo da complementação atual da União ao Fundeb em comparação com o valor que deveria ter sido destinado ao fundo para viabilizar o CAQi em $2012^{12}$ (Tabela 1).

Tabela 1. Estimando complementação da União ao CAQi, com base no Fundeb por Fundo Estadual. Ano: 2012, tendo por base a matrícula de 2011.

\begin{tabular}{|c|c|c|c|c|c|}
\hline \multirow{4}{*}{$\begin{array}{l}\text { Fundo Estadual } \\
\text { por Unidade da } \\
\text { Federaçãa }\end{array}$} & \multicolumn{2}{|c|}{ Fundeb atual } & \multirow[b]{2}{*}{ C } & \multicolumn{2}{|c|}{ Fundeb com CAQi } \\
\hline & A & B & & D & $E=(D-C)$ \\
\hline & $\begin{array}{c}\text { Recursos do } \\
\text { Fundeb aportados } \\
\text { por Estados e } \\
\text { Municípios (previsão } \\
\text { 2012) }\end{array}$ & \begin{tabular}{c}
\multicolumn{2}{c}{ Complemento da } \\
União via Fundeb \\
(previsão 2012)
\end{tabular} & $\begin{array}{l}\text { Total de Recursos } \\
\text { dos Fundos } \\
\text { Estaduais do Fundeb }\end{array}$ & $\begin{array}{l}\text { Recursos } \\
\text { necessários para a } \\
\text { garantia do CAQi via } \\
\text { Fundeb }\end{array}$ & $\begin{array}{c}\text { Complemento } \\
\text { adicional da União } \\
\text { para viabilizar o } \\
\text { CAQi }\end{array}$ \\
\hline & (previsão 2012) & (previsão 2012) & (previsão 2012) & (base 2012) & (base 2012) \\
\hline$A C$ & 638.251 .462 & $\mathrm{~N} / \mathrm{A}$ & 638.251 .462 & 892.533 .114 & 254.281 .652 \\
\hline $\mathrm{AL}$ & 1.682.374.140 & 398.860 & 1.682 .773 .000 & 2.946.708.335 & 1.263 .935 .335 \\
\hline AM & 2.146 .581 .209 & 286.529 & 2.146.867.738 & 3.693.269.631 & 1.546.401.893 \\
\hline AP & 602.612 .554 & $\mathrm{~N} / \mathrm{A}$ & 602.612 .554 & 714.731 .646 & 112.119 .092 \\
\hline $\mathrm{BA}$ & 7.009.382.532 & 2.264 .033 & 7.011 .646 .565 & 12.442 .932 .699 & 5.431 .286 .134 \\
\hline $\mathrm{CE}$ & 3.986 .443 .436 & 1.110 .954 & 3.987 .554 .390 & 6.957 .956 .638 & 2.970 .402 .248 \\
\hline ES & 2.369 .896 .327 & $\mathrm{~N} / \mathrm{A}$ & 2.369 .896 .327 & 2.747.184.091 & 377.287 .764 \\
\hline G0 & 3.001.324.965 & $\mathrm{N} / \mathrm{A}$ & 3.001.324.965 & 3.986 .494 .123 & 985.169 .158 \\
\hline MA & 4.014.974.338 & 2.080 .903 & 4.017 .055 .241 & 7.194.889.337 & 3.177 .834 .096 \\
\hline$M G$ & 9.190 .477 .730 & $\mathrm{~N} / \mathrm{A}$ & 9.190 .477 .730 & 14.239 .418 .434 & 5.048 .940 .704 \\
\hline MS & 1.524.423.065 & $N / A$ & 1.524 .423 .065 & 2.185 .997 .448 & 661.574 .383 \\
\hline MT & 1.654 .640 .284 & $\mathrm{~N} / \mathrm{A}$ & 1.654 .640 .284 & 2.792.431.074 & 1.137 .790 .790 \\
\hline PA & 4.470.574.217 & 2.214 .575 & 4.472.788.792 & 7.968.943.025 & 3.496.154.233 \\
\hline PB & 1.748 .284 .744 & 154.254 & 1.748 .438 .998 & 3.074.561.866 & 1.326 .122 .868 \\
\hline $\mathrm{PE}$ & 3.989.960.495 & 530.611 & 3.990 .491 .106 & 6.828 .064 .711 & 2.837 .573 .605 \\
\hline $\mathrm{PI}$ & 1.673.862.453 & 399.655 & 1.674.262.108 & 2.964.219.788 & 1.289.957.680 \\
\hline $\mathrm{PR}$ & 5.046 .513 .944 & $\mathrm{~N} / \mathrm{A}$ & 5.046 .513 .944 & 7.991.725.526 & 2.945 .211 .582 \\
\hline $\mathrm{RJ}$ & 6.444 .668 .573 & $N / A$ & 6.444 .668 .573 & 9.434 .468 .136 & 2.989 .799 .563 \\
\hline RN & 1.516 .644 .774 & N/A & 1.516 .644 .774 & 2.625.726.952 & 1.109.082.178 \\
\hline Ro & 964.490 .586 & $\mathrm{~N} / \mathrm{A}$ & 964.490 .586 & 1.469 .084 .135 & 504.593 .549 \\
\hline $\mathrm{RR}$ & 425.147 .268 & $\mathrm{~N} / \mathrm{A}$ & 425.147 .268 & 463.824 .317 & 38.677 .049 \\
\hline RS & 5.727.395.131 & $N / A$ & 5.727.395.131 & 7.189.126.056 & 1.461 .730 .925 \\
\hline $\mathrm{SC}$ & 3.427 .561 .011 & $\mathrm{~N} / \mathrm{A}$ & 3.427 .561 .011 & 4.725.302.780 & 1.297.741.769 \\
\hline SE & 1.131 .140 .034 & $N / A$ & 1.131 .140 .034 & 1.708 .260 .222 & 577.120 .188 \\
\hline $\mathrm{SP}$ & 25.903 .591 .684 & $\mathrm{~N} / \mathrm{A}$ & 25.903 .591 .684 & 29.129 .817 .811 & 3.226 .226 .127 \\
\hline TO & 997.087 .938 & $\mathrm{~N} / \mathrm{A}$ & 997.087 .938 & 1.331 .546 .398 & 334.458 .460 \\
\hline TOTAL & 101.288 .304 .893 & 9.440 .374 .000 & 110.728 .678 .893 & 147.699 .218 .292 & 36.970 .539 .399 \\
\hline
\end{tabular}

Fontes: Para as estimativas do Fundeb e matrículas por etapa e modalidade: Portaria Interministerial $\mathrm{n}^{0} 1.809$ de 28/12/2011; Para os valores do CAQi: Quadro 1. 
Como resultado, apenas considerando-se as matrículas atuais, se faz necessária a transferência global de mais de $\mathrm{R} \$ 46,10$ bilhões de reais da União para os Estados, Distrito Federal e Municípios, via o sistema de fundos do Fundeb. Ou seja, os atuais $\mathrm{R} \$$ 9,4 bilhões acrescidos de $\mathrm{R} \$ 36,9$ bilhões. Este valor é quase o quádruplo da previsão da complementação da União para 2012 e seria o volume capaz de garantir o cumprimento do texto constitucional e da LDB, a partir do padrão mínimo de qualidade mensurado pelo CAQi.

Assim, conforme os dados apresentados na Tabela 1, todos os fundos estaduais do Fundeb deveriam receber complementação da União, não apenas nove, como ocorreu em 2012. Somente se quase quintuplicasse sua participação no âmbito do Fundeb é que o governo federal estaria cumprindo integralmente com sua obrigação estabelecida no $\S 1^{\circ}$ do art. 211 da CF, contribuindo efetivamente para reduzir as desigualdades regionais e assegurar padrão mínimo de qualidade de ensino.

$\mathrm{Na}$ análise da Tabela 1 chama a atenção o fato de que mesmo o fundo do Fundeb de São Paulo receberia complementação da União. Isso ocorre por uma razão simples: o valor por aluno para creche no Fundeb está absolutamente abaixo de qualquer relação com o custo real desta etapa. Como o número de matrículas em creche é relativamente alto em São Paulo, se comparado com o restante do país, surge a demanda por recursos adicionais. O mesmo vale para a educação do campo.

O baixo comprometimento da União na educação básica, entre outros prejuízos, tem inviabilizado o cumprimento da Lei do Piso Nacional Salarial do Magistério (Lei 11.738/2008) por parte de muitos entes federados, em especial naquelas regiões mais pobres do país, nas quais o Fundeb é a fonte quase exclusiva de recursos educacionais. Paralelamente a isso, observa-se um incremento das chamadas transferências voluntárias pelo governo federal, ou a gestão baseada em programas. Isso tem obrigado os gestores estaduais e municipais a se submeterem às políticas definidas em Brasília para conseguir alguns parcos recursos para melhorar a educação ofertada por suas administrações. Assim, recria-se uma espécie de nova política de balcão, que estimula práticas pouco cidadãs, atrasando o desenvolvimento da democracia brasileira (NOBRE, 2013).

\section{Necessidade de alterações no Fundeb}

Embora possa ser considerada uma medida insuficiente de coordenação federativa, caso o Fundeb seja fortalecido à luz de maior participação da União como mensura a Nota Técnica da Fineduca, o Brasil daria um grande passo rumo ao fortalecimento da educação básica como um todo.

Nesse sentido, uma emenda da Campanha Nacional pelo Direito à Educação, aprovada por unanimidade na plenária final da I Conae necessita ser transformada em Lei:

b) Alterar a lei do Fundeb no sentido de retirar o sistema de balizas que limitam os fatores de ponderação do fundo a uma escala de 0,7 a 1,3. Esta medida é imprescindível para substituir a atual perspectiva do gasto-aluno/a/ano ou custo-aluno/a/ano existente no fundo, por uma política de custo-aluno/a-qualidade. Concomitantemente, a complementação da União ao Fundeb deve avançar imediatamente para uma transferência equivalente a 1\% do PIB/ano. (BRASIL, 2010b, p. 114).

Ao propor a retirada do sistema de balizas ${ }^{13}$, o objetivo é viabilizar o correto investimento em creches - que, segundo o estudo do CAQi, custa mais do que o dobro do investimento necessário no ensino fundamental anos iniciais - uma vez que as balizas impõem um teto de diferenciação de apenas $30 \%$ para o valor da matrícula para essa etapa. Contudo, apenas a retirada do sistema de balizas não resolve o problema. Como visto anteriormente, é preciso incluir um novo volume de recursos no conjunto do fundo. Desse modo, a emenda propõe que a contribuição da União avance de cerca de $\mathrm{R} \$ 10$ bilhões para $\mathrm{R} \$ 46$ bilhões, adicionado mais de $\mathrm{R} \$ 36,9$ bilhões de dinheiro novo, tal como visto na Tabela 1.

13 As balizas determinam que os valores de todas as etapas e modalidades da educação básica devem ser, no mínimo, 70\% do valor do ensino fundamental anos iniciais (urbano) e, no máximo, 30\% maior do que essa etapa de referência. 0 sistema de balizas, de certo modo, é uma herança do Fundef que só investia no ensino fundamental. 


\section{O CAQi como instrumento de equidade}

Os indicadores educacionais disponíveis, captados pelos exames nacionais de desempenho, pelo censo escolar, pelo censo populacional e pelas pesquisas nacionais de amostragem domiciliar, atestam de forma inequívoca que os esforços até então implementados não foram eficazes para aproximar as condições de oferta educacional dos municípios e estados mais pobres daqueles registrados pelas regiões mais ricas do país, reforçando via a educação as gritantes desigualdades nacionais.

Em 2012, a União Nacional dos Dirigentes Municipais de Educação (Undime) lançou o estudo Perfil dos Gastos Educacionais nos Municípios Brasileiros - Ano Base 2009, com o cálculo do custo real de cada etapa da educação básica empreendida pelos municípios brasileiros. No Gráfico 2, a comparação entre o CAQi e o custo-aluno/ano praticado na região Nordeste, segundo o estudo mencionado, mostra o quanto essa região está distante de alcançar o padrão mínimo de qualidade do ensino, especialmente na educação infantil.

Gráfico 2 - Comparação do custo-aluno/ano da região Nordeste e o CAQi (2009).

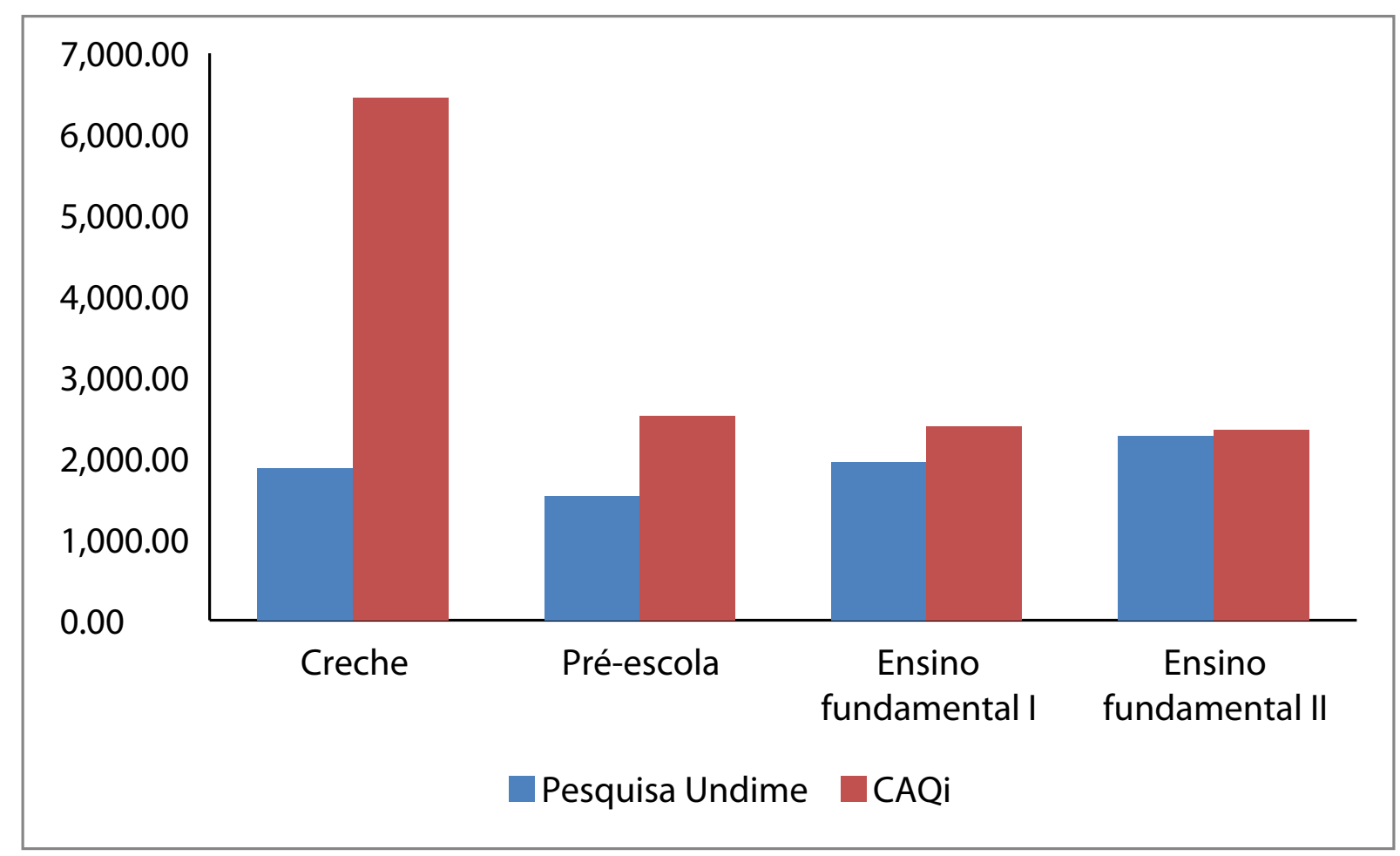

Fonte: Adaptado de Undime (2012) e Campanha Nacional pelo Direito à Educação (2011).

O mecanismo do CAQi é um primeiro passo no longo caminho de melhoria da escola pública no Brasil. Em termos práticos, além de obrigar um primeiro nível de justiça federativa na matéria educacional, sua implementação atenderia também a uma parte importante da demanda calculada pela Campanha Nacional pelo Direito à Educação em sua Nota Técnica (2011), que aponta o custo do novo PNE. Conforme o estudo, para cumprir com as metas do novo plano, garantindo padrão de qualidade tanto para as matrículas atuais quanto para aquelas que precisam ser criadas na educação básica e na educação superior, o Brasil deve investir um patamar equivalente a 10,4\% do PIB em educação pública até o décimo ano do novo plano. Essa demanda é sintetizada na Tabela 2. 


\section{Tabela 2 - Custo adicional do novo PNE.}

\begin{tabular}{|c|c|c|c|}
\hline \multirow{2}{*}{ Categoria } & $\begin{array}{c}\text { Cálculos da Campanha } \\
\text { Nacional pelo Direito à } \\
\text { Educação (R\$) }\end{array}$ & Cálculos do MEC (R\$) & Diferença \\
\cline { 2 - 4 } & $\mathrm{A}$ & $\mathrm{B}$ & $\mathrm{C}=(\mathrm{B}-\mathrm{A})$ \\
\hline Educação infantil & $23.656 .775 .160,00$ & $9.683 .635 .930,00$ & $13.973 .139 .230,00$ \\
\hline Ensino médio & $3.643 .905 .000,00$ & 0 & $3.643 .905 .000,00$ \\
\hline Educação especial & $3.589 .867 .120,00$ & 0 & $3.589 .867 .120,00$ \\
\hline Educação em tempo integral & $23.964 .400 .000,00$ & $3.766 .240 .130,06$ & $20.198 .159 .869,94$ \\
\hline Educação de Jovens e Adultos (EJA) & $21.256 .661 .768,20$ & 0 & $21.256 .661 .768,20$ \\
\hline Educação profissionalizante & $5.927 .954 .879,12$ & $4.456 .014 .000,00$ & $1.471 .940 .879,12$ \\
\hline Educação superior & $45.266 .181 .400,00$ & $15.203 .801 .874,83$ & $30.062 .379 .525,17$ \\
\hline Formação docente & $9.258 .894 .000,00$ & $923.023 .365,76$ & $8.335 .870 .634,24$ \\
\hline Remuneração docente & $33.265 .961 .706,57$ & $27.025 .805 .706,30$ & $6.240 .156 .000,27$ \\
\hline TOTAL & $169.830 .601 .033,89$ & $61.058 .521 .006,95$ & $108.772 .080 .026,94$ \\
\hline \% PIB - 2009* & $5,4 \%$ & $1,9 \%$ & $3,5 \%$ \\
\hline
\end{tabular}

Fonte: Campanha Nacional pelo Direito à Educação, 2011.

* Aqui é apresentado o custo adicional. Segundo o Inep, em 2009, o Brasil investiu 5\% do PIB em educação pública. Portanto, a meta de investimento do novo PNE deve ser de 10,4\% do PIB, segundo a Campanha Nacional pelo Direito à Educação.

Utilizar o CAQi para fortalecer o Fundeb, exigindo maior participação da União no financiamento da educação básica, não é o caminho definitivo para consagrar o direito à educação no Brasil, nem para resolver toda a regulamentação do SNE. Mas pode ser uma referência e um importante e pragmático primeiro passo no enfrentamento das desigualdades federativas brasileiras, melhorando em curto prazo a qualidade da oferta das mais de 40 milhões de matrículas públicas de educação básica que hoje existem no País.

Pontualmente, com a implementação do CAQi, todos os professores que lecionam receberiam pelo menos o piso salarial e teriam 1/3 de sua jornada dedicada ao planejamento de aulas. Concomitantemente, todos os profissionais da educação teriam política de carreira e formação continuada. Além disso, o número de alunos por turma seria adequado e todas as unidades escolares teriam infraestrutura suficiente para a promoção da relação de ensino-aprendizagem, tal como determina a LDB e demandam os artigos 205 e 206 da CF.

Sem dúvida, trata-se de uma boa introdução a uma reivindicação imprescindível já apresentada neste texto: efetivar um investimento equivalente a 10\% do PIB em educação pública até o décimo ano de vigência do PNE, conforme mensura a Nota Técnica da Campanha Nacional pelo Direito à Educação (2011).

Isso é necessário porque implementar o CAQi via Fundeb representa um acréscimo de 1,06\% do PIB no investimento direto em educação básica pública no Brasil. No entanto, aumentar o padrão de qualidade das atuais matrículas de educação básica é insuficiente, pois há 3,7 milhões crianças e adolescentes de 4 a 17 anos fora da escola (UNICEF \& CAMPANHA, 2012), 14 milhões de analfabetos e 3,4 milhões de matrículas em creche precisam ser criadas nos próximos 10 anos (CAMPANHA, 2011). Portanto, é preciso avançar.

Assim, além dos $R \$ 46$ bilhões de reais que a União deve transferir para estados e municípios para o cumprimento do padrão mínimo de qualidade mensurado pelo CAQi, com R\$36,9 bilhões de recursos novos, é preciso insistir no cumprimento das metas do novo PNE. Uma simulação da distribuição dos recursos da educação, por nível de ensino, pode ser vista no Gráfico 3. 
Gráfico 3. Investimento em educação por nível realizado em 2009 versus Custo do PNE II, segundo a Campanha Nacional pelo Direito à Educação, em R\$

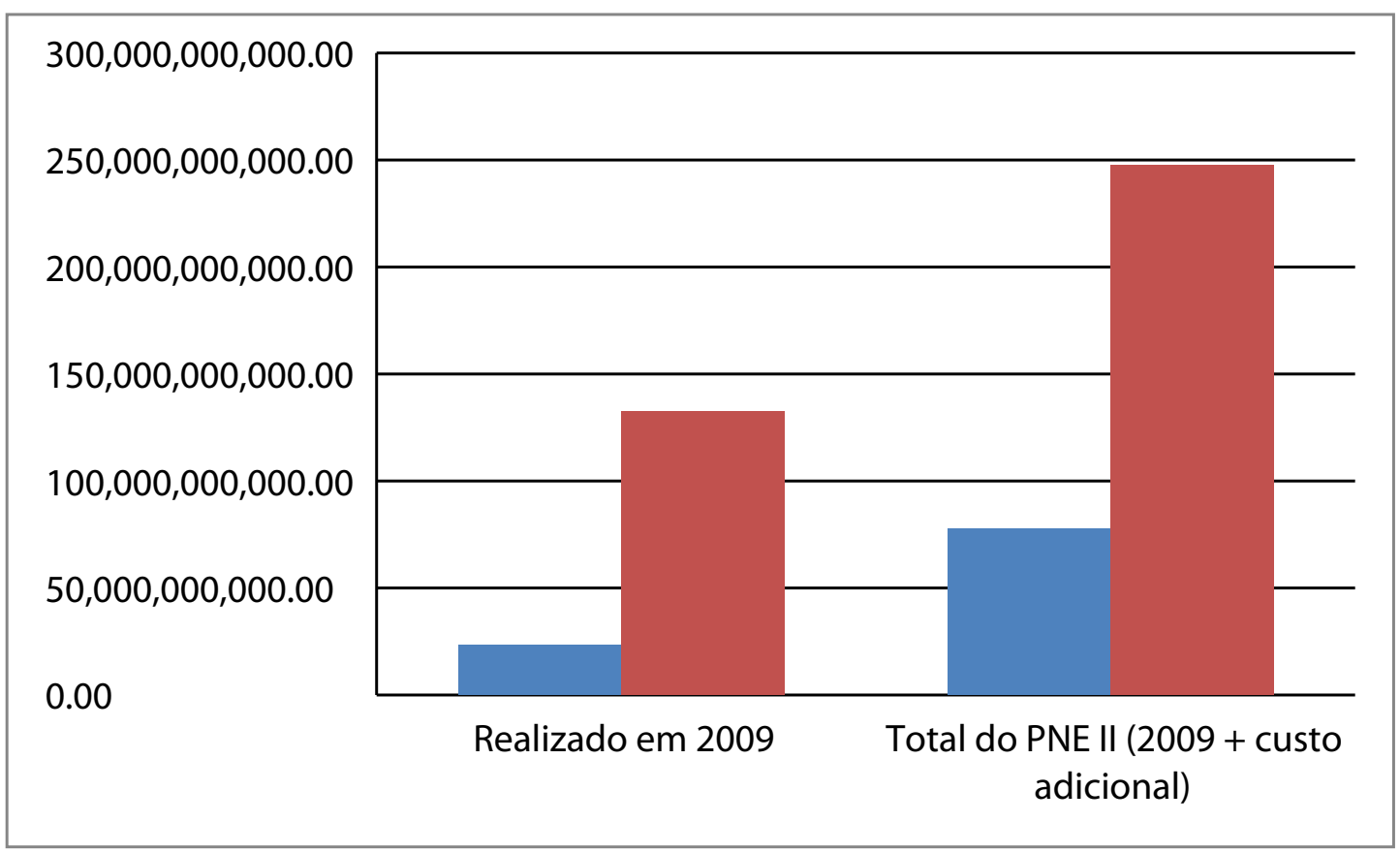

Fonte: Campanha Nacional pelo Direito à Educação (2011).

Em outras palavras, se em 2011 somente a educação básica pública contou com um investimento equivalente a 4\% do PIB (Inep, 2014), a implementação do CAQi - via um justo aumento da complementação da União ao Fundeb - faria com que somente este nível de ensino recebesse um investimento próximo de 4,84\% do PIB. Contudo, para o cumprimento de todas as metas do PNE relativas à educação básica, o Brasil preciso avançar para um patamar equivalente a $8 \%$ do PIB. Essa é a agenda nacional prioritária, considerando que aumentar o financiamento das políticas públicas educacionais é condição necessária, ainda que insuficiente, para a consagração plena do direito à educação - que compreende, necessariamente, acesso e padrão de qualidade, materializado no CAQ.

\section{CAQi e CAQ no PNE}

O novo PNE, na forma da Lei 13.005/2014, faz precisamente esta transição entre o CAQi e o CAQ, estabelecendo um prazo de dois anos para a implementação plena do CAQi, que deve ser idealmente empreendida pelas alteração no Fundeb supracitadas.

No texto original de PNE, elaborado pelo Ministério da Educação, o tema era abordado da seguinte maneira: "20.5) Definir o custo aluno-qualidade da educação básica à luz da ampliação do investimento".

No final, graças à bem-sucedida incidência da Campanha Nacional pelo Direito à Educação na Câmara dos Deputados e a compreensão adquirida pelo relator da matéria na casa, Deputado Angelo Vanhoni, a questão do CAQi e do CAQ ficaram do seguinte modo:

20.5) desenvolver, por meio do Instituto Nacional de Estudos e Pesquisas Educacionais Anísio Teixeira - INEP, estudos e acompanhamento regular dos investimentos e custos por aluno da educação básica e superior pública, em todas as suas etapas e modalidades;

20.6) no prazo de 2 (dois) anos da vigência deste PNE, será implantado o Custo Aluno-Qualidade inicial - CAQi, referenciado no conjunto de padrões mínimos estabelecidos na legislação educacional e cujo financiamento será calculado com base nos respectivos 
insumos indispensáveis ao processo de ensino-aprendizagem e será progressivamente reajustado até a implementação plena do Custo Aluno Qualidade - CAQ;

20.7) implementar o Custo Aluno Qualidade - CAQ como parâmetro para o financiamento da educação de todas etapas e modalidades da educação básica, a partir do cálculo e do acompanhamento regular dos indicadores de gastos educacionais com investimentos em qualificação e remuneração do pessoal docente e dos demais profissionais da educação pública, em aquisição, manutenção, construção e conservação de instalações e equipamentos necessários ao ensino e em aquisição de material didático-escolar, alimentação e transporte escolar;

20.8) o CAQ será definido no prazo de 3 (três) anos e será continuamente ajustado, com base em metodologia formulada pelo Ministério da Educação - MEC, e acompanhado pelo Fórum Nacional de Educação - FNE, pelo Conselho Nacional de Educação - CNE e pelas Comissões de Educação da Câmara dos Deputados e de Educação, Cultura e Esportes do Senado Federal;

20.9) regulamentar o parágrafo único do art. 23 e 0 art. 211 da Constituição Federal, no prazo de 2 (dois) anos, por lei complementar, de forma a estabelecer as normas de cooperação entre a União, os Estados, o Distrito Federal e os Municípios, em matéria educacional, e a articulação do sistema nacional de educação em regime de colaboração, com equilíbrio na repartição das responsabilidades e dos recursos e efetivo cumprimento das funções redistributiva e supletiva da União no combate às desigualdades educacionais regionais, com especial atenção às regiões Norte e Nordeste

20.10) caberáà União, na forma da lei, a complementação de recursos financeiros a todos os Estados, ao Distrito Federal e aos Municípios que não conseguirem atingir o valor do CAQi e, posteriormente, do CAQ.

Como resultado, em dois anos, além de iniciar a busca pelo padrão mínimo de qualidade materializado com o CAQi, a distribuição federativa de recursos ficará mais justa, tal como confirma o Gráfico 4, abaixo.

Gráfico 4. Projeção da participação do investimento direto em educação, por ente federado (2012), com a implementação da Estratégia 20.10 do PNE.

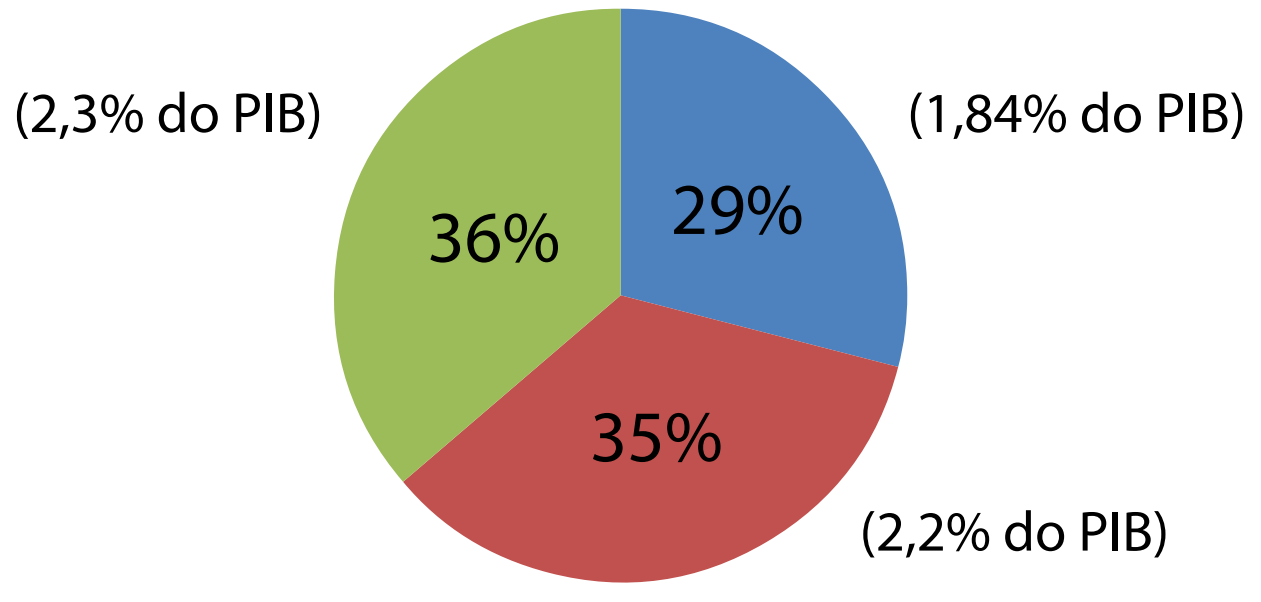

-União "Estados e DF "Municípios

Fonte: Adaptado de Inep (2014). 


\section{Referências}

ABRUCIO, F. L. A dinâmica federativa da educação brasileira: diagnóstico e propostas de aperfeiçoamento. In: OLIVEIRA, R. P.; SANTANA, W. (Orgs.). Educação e federalismo no Brasil: combater desigualdades, garantir a diversidade. Brasília, DF: Unesco, 2010, p. 39-70.

ARAUJO, G. C. Município, federação e educação: história das instituições e das ideias políticas no Brasil. 2005. Tese (Doutorado em Educação) - Faculdade de Educação, Universidade de São Paulo, São Paulo, 2005. ARRETCHE, M. Federalismo e políticas sociais no Brasil: problemas de coordenação e autonomia. São Paulo em Perspectiva, São Paulo, v. 18, n. 2, p. 17-26, abr./jun. 2004. Disponível em: <http://dx.doi.org/10.1590/S010288392004000200003 >. Acesso em: 14 de maio de 2012.

ASSOCIAÇÃO NACIONAL DE PESQUISADORES EM FINANCIAMENTO DA EDUCAÇÃO. Por que a União deve complementar o CAQi no PNE? Disponível em: <http:// http://www.redefinanciamento.ufpr.br/nota1_13. pdf $>$. Acesso em: 13 de dezembro de 2014.

BRASIL. Constituição (1988). Constituição da República Federativa do Brasil. Brasília, DF: Senado Federal, 1988.

. Lei n 9.394, de 20 de dezembro de 1996. Estabelece diretrizes e bases da educação nacional. Diário Oficial da União, Brasília, DF, 23 dez. 1996.

. Lei n 10.172, de 9 de janeiro de 2001. Aprova o Plano Nacional de Educação e dá outras providências. Diário Oficial da União, Brasília, DF, 10 jan. 2001.

Lei no 11.494, de 20 de junho de 2007. Regulamenta o Fundo de Manutenção e Desenvolvimento da Educação Básica e de Valorização dos Profissionais da Educação - FUNDEB, de que trata o art. 60 do Ato das Disposições Constitucionais Transitórias; altera a Lei $n^{\circ}$ 10.195, de 14 de fevereiro de 2001; revoga dispositivos das Leis nos 9.424, de 24 de dezembro de 1996, 10.880, de 9 de junho de 2004, e 10.845, de 5 de março de 2004; e dá outras providências. Diário Oficial da União, Brasília, DF, 21 jun. 2007b.

Emenda Constitucional $n^{\circ}$ 59, de 11 de novembro de 2009. Acrescenta $\S 3^{\circ}$ ao art. 76 do Ato das Disposições Constitucionais Transitórias para reduzir, anualmente, a partir do exercício de 2009, o percentual da Desvinculação das Receitas da União incidente sobre os recursos destinados à manutenção e desenvolvimento do ensino de que trata o art. 212 da Constituição Federal, dá nova redação aos incisos I e VII do art. 208, de forma a prever a obrigatoriedade do ensino de quatro a dezessete anos e ampliar a abrangência dos programas suplementares para todas as etapas da educação básica, e dá nova redação ao $\S 4^{\circ}$ do art. 211 e ao $\S 3^{\circ}$ do art. 212 e ao caput do art. 214, com a inserção neste dispositivo de inciso VI. Diário Oficial da União, Brasília, DF, 12 nov. 2009.

Ministério da Educação. Conselho Nacional de Educação. Parecer CNE/CEB n 8, de 5 de maio de 2010. Estabelece normas para aplicação do inciso IX do artigo $4^{\circ}$ da Lei n 9.394/96 (LDB), que trata dos padrões mínimos de qualidade de ensino para a Educação Básica pública. Ministério da Educação, 2010a. Disponível em: $\quad<$ http://portal.mec.gov.br/index.php?option=com_docman\&task=doc_download\&gid=5368\&ltemid=>. Acesso em: ago. 2012.

Ministério da Educação. Conferência Nacional de Educação. Construindo o sistema nacional articulado de educação: o Plano Nacional de Educação, diretrizes e estratégias; documento final. Brasília, DF: MEC, $2010 b$.

Instituto Nacional de Estudos e Pesquisas Educacionais Anísio Teixeira. Indicadores Financeiros Educacionais. Brasília, DF: 2014.

CAMPANHA NACIONAL PELO DIREITO À EDUCAÇÃO. Nota técnica - por que 7\% do PIB para a educação é pouco? Cálculo dos investimentos adicionais necessários para o novo PNE garantir um padrão máximo de qualidade. São Paulo, 2011. 
CARREIRA, D.; PINTO, J. M. R. Custo aluno-qualidade inicial: rumo à educação pública de qualidade no Brasil. São Paulo: Global; Campanha Nacional pelo Direito à Educação, 2007.

CARA, D. Mais dinheiro federal na educação básica. Sessão Tendências e Debates. Folha de S. Paulo: São Paulo. 03 de fevereiro de 2012a.

Municípios no pacto federativo: fragilidades sobrepostas. Revista Retratos da Escola, Brasília, v. 6, n. 10, p. 255-273, jan./jun. 2012b.

CURY, C. R. J. Federalismo político e educacional. In: FERREIRA, Naura Syria Carapeto (Org.). Políticas públicas e gestão da educação: polêmicas, fundamentos e análises. Brasília, DF: Líber Livro, 2006.

ESTADOS UNIDOS DA AMÉRICA. Constituição (1789). Constituição dos Estados Unidos da América. Washington, D.C.: Convenção Constitucional, 1978.

FEDERAÇÃO DAS INDÚSTRIAS DO ESTADO DO RIO DE JANEIRO (FIRJAN). Índice FIRJAN de Gestão Fiscal (IFGF). Rio de Janeiro, 2012. Disponível em: <http://www.firjan.org.br/IFGF/>. Acesso em: 1 de maio de 2012.

HAMILTON, A.; MADISON, J.; JAY, J. O federalista. Brasília, DF: Editora Universidade de Brasília, 1984.

INSTITUTO BRASILEIRO DE GEOGRAFIA E ESTATíSTICA. Perfil dos Municípios Brasileiros - 2011. Rio de Janeiro, 2013. Disponível em: http://www.ibge.gov.br/home/estatistica/economia/perfilmunic/2011/default.shtm. Acesso em: 13 de fevereiro de 2013.

INSTITUTO NACIONAL DE ESTUDOS E PESQUISAS EDUCACIONAIS ANÍSIO TEIXEIRA (INEP). Sinopse estatística da educação básica: censo escolar 2006. Brasília, DF, 2007.

INSTITUTO DE PESQUISA ECONÔMICA APLICADA (IPEA). № 124 - Financiamento da educação: necessidades e possibilidades. Comunicados do Ipea, Brasília, DF, 14 dez. 2011. Disponível em: <http:// www.ipea.gov.br/portal/images/stories/PDFs/comunicado/111214_comunicadoipea124.pdf>. Acesso em: 1 de maio de 2012.

Brasil em desenvolvimento 2011: Estado, planejamento e políticas públicas. Brasília, DF, 2012a.

Políticas sociais: acompanhamento e análise. n. 20. Brasília, DF, 2012b. Disponível em: <http:// www.ipea.gov.br/portal/images/stories/PDFs/politicas_sociais/bps_20_completo.pdf>. Acesso em: 1 de maio de 2012.

LIMONGI, F. P. "O federalista": remédios republicanos para males republicanos. In: WEFFORT, Francisco (Org.). Os clássicos da política. 14. ed. São Paulo: Ática, 2006, p. 243-287.

MARTINS, P. de S.. Fundeb, federalismo e regime de colaboração. Campinas: Autores Associados, 2011. MONTESQUIEU, C. L. O espírito das leis. Genebra: Barrillot, 1750.

NOBRE, M. Choque de democracia - Razões da revolta. Companhia das Letras (edição Digital), 2013.

SOARES NETO, J. J.; JESUS, G. R.; KARINO, C. A.; ANDRADE, D. F. Uma escala para medir a infraestrutura escolar. Est. Aval. Educ, 2013. vol.24, n.54, pp. 78-99.

UNIÃO NACIONAL DOS DIRIGENTES MUNICIPAIS DE EDUCAÇÃO (UNDIME). Relatório de pesquisa perfil dos gastos educacionais nos municípios brasileiros - ano base: 2009. Brasília, DF, 2012.

UNICEF. CAMPANHA NACIONAL PELO DIREITO À EDUCAÇÃO. Relatório de pesquisa - Fora da escola não pode. Brasília, DF, 2012.

Recebido em Agosto de 2014 - Aprovado em Outubro de 2014 


\title{
O debate acerca do financiamento da educação na etapa municipal da Conae 2013/2014 de Curitiba-PR
}

\section{The debate about Financing of Education in 2013/2014 Curitiba Conae's Conference}

\author{
El debate sobre el financiamiento de la educación en la etapa \\ municipal de la Conae 2013/2014 de Curitiba-PR
}

Jokasta Pires Vieira Ferraz ${ }^{1}$ Ângelo Ricardo de Souza²

\begin{abstract}
Resumo
O artigo aborda os resultados dos debates na etapa municipal da Conferência Nacional de Educação de 2014 (Conae) em Curitiba, no que tange à temática do financiamento da educação, um dos sete eixos da Conae. O texto procura analisar as emendas aprovadas com participação dos diferentes segmentos da comunidade, na medida em que elas representam as ideias que predominaram no debate. O trabalho, ao final, ainda destaca a importância da atualização e constante vigilância no entorno deste temática, tendo em vista a sua centralidade na materialização da política educacional no Brasil.

Palavras-chave: Financiamento da Educação; Políticas Educacionais; Conae 2014.
\end{abstract}

\begin{abstract}
The article discusses the results of the debates in the municipal stage of the National Education Conference 2014 (Conae) in Curitiba, with respect to the topic of education funding, one of the seven axes of Conae. The paper analyzes the approved amendments with participation of different segments of the community, considering that they represent the ideas that prevailed in the debate. At the end, the work also emphasized the importance of updating and constant vigilance surrounding this theme, with the idea about its centrality in the materialization of educational policy in Brazil.

Keywords: Financing of Education; Educational policies; Conae 2014.
\end{abstract}

\section{Resumen}

El artículo analiza los resultados de los debates en la etapa municipal de la Conferencia Nacional de Educación 2014 (Conae) en Curitiba, con respecto al tema del financiamienton de la educación, uno de los siete ejes de la Conae. El artículo analiza las modificaciones aprobadas con la participación de diferentes sectores de la comunidad, en la medida en que representan las ideas que prevalecieron en este debate. El trabajo al final, también ha demostrado la importancia de la actualización y una vigilancia constante en torno a este tema, considerando su centralidad en la materialización de la política educativa en Brasil.

Palabras-clave: Financiamiento de la Educación; Políticas Educativas; Conae 2014.

1 Mestre em Educação. Professora da Rede Municipal de Ensino de Curitiba. E-mail: jokastaferraz@hotmail.com 2 Doutor em Educação. Professor e pesquisador do Núcleo de Políticas Educacionais e do Programa de Pós-Graduação em Educação da UFPR. E-mail: angelo@ufpr.br 


\section{Introdução}

Em 2013 no município de Curitiba foi organizada uma das etapas municipais da Conferência Nacional de Educação (Conae), entre tantas outras que aconteceram pelo Brasil. A conferência é formada pelo poder público e pela sociedade civil organizada, e teve como objetivos na etapa municipal: a) analisar o documento de referência nacional da Conae, b) discutir e estruturar propostas de emendas para este documento, c) encaminhar as emendas propostas e aprovadas em assembleia, para etapa estadual da Conae. As diversas conferências realizadas em todo país no ano de 2013 tiveram o intuito de contribuir para construção do novo Plano Nacional de Educação (PNE 2014-2014), que viria a ser aprovado em junho com a lei 13.005/2014.

A participação da sociedade na definição de metas para educação brasileira confere legitimidade ao PNE, bem como a sua elaboração articulada entre os entes federados une as metas às responsabilidades legais de cada ente, mas há também a inserção de interesse das instituições privadas nas discussões. Sendo assim, temos um espaço público de discussão e todo esse processo de participação pressupõe disputa de poder. Essas relações ficam expressas nas emendas aprovadas, pois a sua aprovação é condicionada à participação de segmentos que defendem determinadas ideias, e se posicionem sobre direitos e ações governamentais.

O objetivo deste texto é abordar o resultado deste debate na etapa municipal da Conae na cidade de Curitiba, procurando analisar as emendas aprovadas com participação dos diferentes segmentos da comunidade, na medida em que compreendemos que as emendas aprovadas representam as ideias que predominaram no debate, bem como os grupos que tiveram mais força para propor alterações.

Conforme o documento referência houve sete eixos para discussões: I) O Plano Nacional de Educação e o Sistema Nacional de Educação: organização e regulação; II) Educação e diversidade: justiça social, inclusão e direitos humanos; III) Educação, trabalho e desenvolvimento sustentável: cultura ciência, tecnologia, saúde e meio ambiente e desenvolvimento sustentável; IV) Qualidade da educação: democratização do acesso, permanência, avaliação, condições de participação e aprendizagem; V) Gestão democrática, participação popular e controle social; VI) Valorização dos profissionais da educação: formação, remuneração, carreira, e condições de trabalho; e o eixo VII) Financiamento da educação. O financiamento da educação é o eixo escolhido para análise proposta neste texto.

\section{Contextualizando o eixo VII: O financiamento da educação no Brasil}

Antes de analisar as emedas apresentadas no eixo VII, cabe apresentar brevemente a estrutura do financiamento da educação brasileira, pois é ela que é posta em discussão no referido eixo.

O financiamento da educação tem como principal fonte de recursos a vinculação da receita de impostos, com uma porcentagem mínima de investimento segundo o artigo 212 da Constituição Federal (CF) de 1988, que é organizada da seguinte forma,

A União aplicará, anualmente, nunca menos de dezoito, e os Estados, o Distrito Federal e os Municípios vinte e cinco por cento, no mínimo, da receita resultante de impostos, compreendida a proveniente de transferências, na manutenção e desenvolvimento do ensino (BRASIL, 1988).

Entretanto, podemos afirmar que é o investimento ${ }^{3}$ em educação ocorre proporcionalmente à arrecadação da união, estados, municípios e Distrito Federal. Sendo assim, a vinculação da receita de impostos age primeiro na regulamentação da aplicação dos recursos, o que vem a assegurar porcentagem mínima de investimento, entretanto, como grande parte dos municípios brasileiros possui baixa arrecadação, a vinculação, por si só, principalmente no caso de alguns entes federados municipais, não assegura valores significativos de investimento.

3 Quando usado 0 termo investimento, não estamos nos referindo ao conceito dado pela economia, na qual o termo significa uma aplicação que busca gerar maior produção ou retorno financeiro. Ao tratar o gasto em educação como investimento, vislumbramos sim, um retorno, porém este se traduz, de forma pedagógica na aprendizagem dos alunos e na qualidade da educação que é oferecida (FERRAZ, 2013, p.3). 
Todavia, com a competência supletiva e redistributiva atribuída à União, o governo federal tem o papel de equalizar a distribuição desses recursos, e um dos mecanismos para tal é a subvinculação da receita de impostos, efetivada pelo Fundo de Manutenção e Desenvolvimento do Ensino Fundamental e de Valorização do Magistério - Fundef, que teve vigência de 1998 até 2006, e pelo Fundo de Manutenção e Desenvolvimento da Educação Básica e de Valorização dos Profissionais da Educação - Fundeb, que foi iniciado em 2007 e tem vigência determinada até 2020.

A proposta da política de fundos é de redistribuição de recursos em âmbito estadual. Os que fundos promovem é uma subvinculação, que no caso do Fundef foi de $15 \%$ da receita de alguns impostos ${ }^{4}$, sendo que os recursos eram destinados apenas para o ensino fundamental. Com o advento do Fundeb, os recursos passaram a ser distribuídos para toda a educação básica e a subvinculação aumentou para 20\%, além de terem sido acrescidos alguns impostos à cesta ${ }^{5}$. Nesse modelo, a política de fundos pode ainda contar com a complementação da União em cada um dos fundos estaduais, quando estes não alcançam o valor mínimo anual por aluno determinado pela presidência da República.

A redistribuição dos recursos do Fundeb segue critérios estipulados anualmente, conforme resolução do Ministério da Educação, por exemplo, os fatores de ponderação aprovados em 2013 para o exercício de 2014, são:

I - creche em tempo integral:

a) pública: 1,30;

b) conveniada: 1,10 .

II - pré-escola em tempo integral: 1,30;

III - creche em tempo parcial:

a) pública: 1,00 ;

b) conveniada: 0,80 .

IV - pré-escola em tempo parcial: 1,00;

$V$ - anos iniciais do ensino fundamental urbano: 1,00;

$\mathrm{VI}$ - anos iniciais do ensino fundamental no campo: 1,15;

VII - anos finais do ensino fundamental urbano: 1,10;

VIII - anos finais do ensino fundamental no campo: 1,20;

IX - ensino fundamental em tempo integral: 1,30;

$X$ - ensino médio urbano: 1,25;

$X I$ - ensino médio no campo: 1,30;

XII - ensino médio em tempo integral: 1,30;

XIII - ensino médio integrado à educação profissional: 1,30;

XIV - educação especial: 1,20;

$X V$ - educação indígena e quilombola: 1,20;

$X V I$ - educação de jovens e adultos com avaliação no processo: 0,80; e

XVII - educação de jovens e adultos integrada à educação profissional de nível médio, com avaliação no processo: 1,20 (MEC, Resolução № 1, de 31 de dezembro de 2014).

4 Fundo de Participação dos Estados - FPE, Fundo de Participação dos Municípios - FPM, Imposto sobre Circulação de Mercadorias e Serviços - ICMS, Imposto sobre Produtos Industrializados, proporcional às exportações - IPIExp, Desoneração de Exportações (LC 87/96).

5 Imposto sobre Transmissão Causa Mortis - ITCM, Imposto sobre Propriedade de Veículos Automotores - IPVA, Imposto sobre Renda e Proventos incidentes sobre rendimentos pagos pelos Municípios, Imposto sobre Renda e Proventos incidentes sobre rendimentos pagos pelos Estados, Quota Parte de $\mathbf{5 0 \%}$ do Imposto Territorial Rural devida aos Municípios - ITR. 
Na redistribuição dos recursos eles são distribuídos conforme o número de matrículas e os fatores de ponderação para cada etapa e modalidade de ensino, conforme listado, o que significa que as matrículas são contabilizadas com pesos distintos, reconhecendo-se que alunos de etapas ou modalidades distintas necessitam de recursos distintos.

Para além dos recursos já citados, o financiamento da educação também conta com o salário-educação (contribuição social inteiramente vinculada à educação), cujos recursos são administrados pelo Fundo Nacional de Desenvolvimento da Educação (FNDE) . $^{6}$

A organização do financiamento da educação no Brasil pode passar por mudanças dentro de alguns anos, pois em 2020 encerra a vigência do Fundeb. É certo que apenas uma mudança muito drástica no modelo tributário brasileiro poderia dispensar a existência de uma política como esta, por isto, parece-nos que sem uma reforma tributária ampla, o Fundeb tende a continuar após esta data, o que implica em rediscussão e aprovação de novo prazo e, quiçá, novo modelo.

Ademais, o PNE aprovado pela lei $n^{\circ} 13.005$ de 2014, aponta para diversas demandas, dentre as quais, emblematicamente temos a aprovação da meta de ampliação do investimento em educação de maneira a atingir a porcentagem de $10 \%$ do PIB brasileiro.

Feita a descrição da estrutura brasileira de financiamento da educação pública, podemos olhar para o texto da Conae e para as emendas analisando sua relação com um panorama maior.

\section{O texto base da Conae 2014}

O texto base da Conae 2014, no que tange ao financiamento da educação, considera esta temática uma peça-chave na organização da educação brasileira:

0 financiamento da educação é elemento estruturante para a organização e o funcionamento das políticas públicas educacionais e, desse modo, para materialização do SNE. Embora não seja fator suficiente, é condição necessária para a universalização do direito à educação pública de qualidade (BRASIL, 2013, p. 84)

Compatível com esta importância, o texto mostra a centralidade do financiamento da educação na política educacional brasileira, evidenciando, por exemplo, o importante papel da Emenda Constitucional 59/2009, que inclui no texto constitucional brasileiro a obrigatoriedade, quando da elaboração do PNE, de uma meta que vincule o investimento público em educação a um percentual do Produto Interno Bruto (PIB) do país.

Contudo, o texto reconhece, mesmo que indiretamente, as dificuldades atreladas à temática do financiamento, em especial por conta do desenho federativo brasileiro, destacando que mesmo a CF reconhecendo o financiamento adequado da educação como um pilar na edificação de políticas mais efetivas, isto só se traduzirá na prática com a implementação de um SNE articulado, que integre e coloque em colaboração efetiva os entes federados.

Esta articulação remete à reflexão sobre a gestão dos recursos. Por isto, o texto base da Conae 2014 destaca a importância da gestão democrática e do controle social sobre os recursos públicos da educação. Por isto, o texto aponta para a importância dos Conselhos de Acompanhamento e Controle Social (CACS) do Fundeb, pois a eles cabe a tarefa de fiscalizar a aplicação do maior contingente de recursos públicos para a educação básica no país.

Na direção de uma melhor gestão, o texto propõe que os secretários de educação possam assumir a gestão dos recursos vinculados à educação, retirando o controle financista ou economicista que normalmente recai

6 Dentre os programas do FNDE que são financiados com este tributo estão: Alimentação escolar, Banda larga nas escolas, Biblioteca na escola (PNBE), Caminho da escola, Dinheiro direto na Escola (PDDE), Licitação e registro de preços, Livro didático (PNLD), PDE escola, Plano de Ação de Aceleração (PAC II), Plano de Ações Articuladas (PAR), Prestação de contas (Contas Online), Programa Um Computador por Aluno (Prouca), Proinfância, Prolnfo, Repasses diretos, Transporte escolar (PNATE).

Fonte: $h$ htp://www.fnde.gov.br/fnde/institucional/perguntasfrequentes/programas. Acesso em 15/08/2014 
sobre o modelo mais comum de organização das finanças públicas, no qual a mencionada gestão é feita pelo secretário da fazenda pública.

O texto, na sequência, é enfático na defesa da ampliação dos gastos públicos em educação, de maneira a se atingir pelo menos $10 \%$ do PIB, meta que acabou consagrada no texto aprovado do PNE, em junho de 20147. Nesta mesma direção, da necessidade de ampliação dos recursos, o texto avalia que os percentuais de vinculação orçamentária como definidos na CF não são suficientes para suprir as crescentes demandas educacionais brasileiras, nem mesmo para dar conta das demandas reprimidas ou mal atendidas historicamente.

Mas, para além da gestão e da ampliação dos recursos, o texto também defende a construção do Custo-Aluno Qualidade (CAQ) como elemento equalizador, tendo em vista a enorme desigualdade entre os entes federados e que, tendo em vista a proposta básica de $C A Q$, garante condições de qualidade para a educação brasileira.

Finalmente, o texto base da Conae 2014 apresenta um conjunto de proposições e estratégias, focalizando: a) a regulamentação do regime de colaboração entre os entes federados; b) redefinição do modelo de financiamento da educação, considerando a capacidade arrecadatória dos entes federados; c) ampliação dos investimentos públicos em educação, de maneira a atingir pelo menos 10\% do PIB; d) garantir novas fontes de financiamento da educação, bem como articular essas fontes e o novo PNE com as outras peças legais que incidem sobre o orçamento público brasileiro; e) ampliar o percentual de vinculação orçamentária para 25\% (União) e 30\% (Estados, Distrito Federal e Municípios), pelo menos; f) deixar de considerar os gastos com aposentadorias e pensões dos gastos como despesas com MDE; g) implementar o CAQi e construir o CAQ; h) reorganizar peças legais, como a LRF, para garantir ampliação das possibilidades de financiamento para a educação; i) alterar e melhorar a política de fundos ${ }^{8}$; dentre outras metas.

\section{Análise das emendas aprovadas}

Da documentação da etapa municipal da Conae, em Curitiba, foram disponibilizados para consulta as ementas aprovadas e estas foram organizadas em dois quadros, o quadro 1 contém as emendas aditivas, totalizando 33 emendas com 23 assuntos diversos. Cada número de referência diz respeito a uma emenda e o assunto do seu referido teor está descrito na coluna "conteúdo".

As emendas aditivas em maior número são as quem procuraram priorizar os recursos para a educação pública, reforçando sempre ao sugerir adicionar a expressão "educação pública" à construção do texto. Essa preocupação buscou assegurar que fosse contemplando o que a Lei de Diretrizes e Bases da Educação Nacional (LDB), Lei Federal 9394/96, não assegura, pois segundo seu artigo 70, considera-se como despesas com MDE, por exemplo, concessão de bolsas de estudo para alunos de escolas privadas. Assim, a leitura dos proponentes de tais emendas é de que o mencionado artigo dá espaço para que os recursos públicos não sejam unicamente investidos na educação pública.

O custo aluno-qualidade (CAQ) está presente em duas emendas e o custo aluno-qualidade inicial (CAQi), em uma, as quais reiteram a preocupação de que o financiamento deve assegurar qualidade e esta deve ser critério para execução dos recursos. A preocupação com o acompanhamento e controle dos recursos também é uma constante, por meio das ementas que tratam sobre o papel do ministério público, sobre a gestão democrática, bem como sobre conselhos e controle social.

Temáticas ligadas às diversidades (afrodescendentes, indígenas, quilombolas, povos e comunidades tradicionais, étnico-raciais e gênero) também permeiam o texto das emedas aditivas. De certa forma, podemos

7 Quando da elaboração do texto base da Conae 2014, o PNE ainda estava em tramitação e, portanto, não se sabia se o Congresso Nacional iria aprovar esta meta, e depois se a Presidenta iria ou não sancioná-la.

80 texto faz uma série de recomendações sobre como o Fundeb pode ser melhorado. 
considerar que se houve alguma necessidade de emendas aditivas é porque a temática deixou de ser contemplada da melhor forma no texto base, além disso, as aprovações destas emendas confirmam a demanda para se pensar e projetar políticas especificas de financiamento.

De maneira geral, as emendas aditivas parecem estar em consonância com as discussões em nível nacional, tendo em vista que vários dos assuntos estiveram presentes na etapa nacional da Conae, além de causarem polêmica na aprovação do PNE, como as questões relativas à igualdade de gênero.

\section{Quadro 1: Emendas aditivas - CONAE Curitiba}

\begin{tabular}{|c|c|c|c|}
\hline Emenda & Quantidade & Conteúdo & Referência \\
\hline & & $\begin{array}{l}\text { Afrodescendentes, indígenas, quilombolas, povos e } \\
\text { comunidades tradicionais e egressos da EJA }\end{array}$ & 502 \\
\hline & & $\mathrm{CAQ}$ & 479 e 480 \\
\hline & & Conselhos & 515 \\
\hline & & Controle social & 453 \\
\hline & & Desigualdades regionais e étnico-raciais & 495 \\
\hline & & Educação básica pública & 508 \\
\hline & & Educação profissional pública & 507 \\
\hline & & Educação pública & $\begin{array}{c}449,451,454,456,466,470,474 \\
475,476,481\end{array}$ \\
\hline & & Ensino superior e distribuição de recursos & 499 \\
\hline & & $\begin{array}{l}\text { Funbed, CAQi, EJA, creches e escolas de ed. especial } \\
\text { conveniadas }\end{array}$ & 488 \\
\hline & & Gestão democrática, controle social & 511.5 .4 \\
\hline \multirow[t]{11}{*}{ Aditiva } & \multirow[t]{11}{*}{33} & $\begin{array}{l}\text { Informatizar gestão considerando as especificidades dos } \\
\text { diferentes níveis, etapas e modalidades de educação. }\end{array}$ & 510 \\
\hline & & Manutenção de equipamentos públicos & 487 \\
\hline & & $\begin{array}{c}\text { Ministério público, Conselhos municipais de educação } \\
\text { deliberativos }\end{array}$ & 463 \\
\hline & & $\begin{array}{l}\text { Pesquisas que levem em conta relações assimétricas, étnico- } \\
\text { raciais e de gênero }\end{array}$ & 482 \\
\hline & & $\begin{array}{c}\text { Pós-graduação stricto sensu com politicas de acesso e } \\
\text { permanência para todos }\end{array}$ & 505 \\
\hline & & Pós-graduação stricto e lato & 503 \\
\hline & & Profissionais da educação & 485 \\
\hline & & Receitas e despesas por nível, etapa e modalidade & 518 \\
\hline & & Regime estatutário & 450 \\
\hline & & Todos os níveis, etapas e modalidade & 471 e 472 \\
\hline & & Transporte escolar e EJA & 491 \\
\hline
\end{tabular}

Fonte: Arquivos Conae Curitiba - Informações organizadas pelos autores, 2013. 
No segundo quadro, temos uma quantidade menor de emendas, porém algumas com grandes pretensões, abordando elementos que se diferem do que já é previsto em lei, como por exemplo, a desvinculação do pagamento dos trabalhadores da educação da folha de pagamento geral para efeitos dos cálculos dos gastos públicos estabelecidos pela Lei de Responsabilidade Fiscal (LRF), mas ao mesmo tempo elimina algum possível empecilho na valorização salarial dos trabalhadores.

Sobre a garantia do transporte escolar com recursos além dos destinados à MDE, parece haver nas emendas uma estratégia de assegurar recursos para além dos $25 \%$ vinculados constitucionalmente, entretanto, no caso do Paraná, existe uma normatização específica para a oferta do transporte escolar, que é o Provimento 1/99 do Tribunal de Contas do Paraná, que prevê regras claras para compra ou locação de veículos, conforme for mais econômico, ademais a aquisição de vales-transportes não se caracterizaria como transporte escolar, ou seja, regras para o bom o uso dos recursos existem, cabe refletir se maior controle social não melhoraria o uso do recurso.

Cabe também observar que já existem recursos para além dos $25 \%$ que são destinados ao transporte escolar, que é o Programa Nacional de Apoio ao Transporte do Escolar (Pnate), porém este é destinado especialmente a alunos moradores da zona rural. Com essas considerações, cabe refletir se a proposição da ampliação/melhoria do programa, com recursos do FNDE, não seria mais interessante do que indicar a desvinculação dos gastos com MDE, pois assim se tem diretrizes mais claras de organização e fontes de recursos.

Outra emenda interessante trata sobre os recursos do salário educação, propondo a ampliação da contribuição de 2,5\% para 3,5\% sobre a folha de pagamento. Esta proposta, se efetivada, apresentaria um ganho real para os programas e políticas gerenciados pelo FNDE, pois a integralidade desses recursos é destinada para educação.

A nova emenda apresentou a defesa da interrupção, em 2018, da transferência de benefícios para iniciativa privada. Esta emenda apoia as emendas aditivas sobre recursos públicos para a educação pública, entretanto tal ação, se de fato efetivada, impactaria em diversos programas federais consolidados, principalmente nos destinados ao ensino superior e técnico, além disso, as políticas de convênio existentes em grande parte na educação especial e infantil, também sofreriam com uma medida como esta. Uma estratégia coerente seria atrelar o cessamento dos recursos para instituições privadas com uma meta de atendimento dessa população pelo poder público em instituições públicas. Este é, de resto, um assunto complexo e que pautou, e ainda pautará por algum tempo, o debate nacional (e mesmo internacional) sobre educação, que é a relação públicoprivado. Parece-nos que, mesmo meritória, a emenda em tela não conseguiria se efetivar em prazo tão exíguo, particularmente na educação infantil e educação especial. Todavia, com um plano mais a longo prazo e, como mencionado, com metas de atendimento explícitas pelo poder público, parece possível se desenhar um futuro no qual o dinheiro público deixe de subsidiar as ações e instituições privadas na educação brasileira.

A emenda substitutiva sobre "estímulo e consulta aos PPPs, currículos, regimentos, planos de gestão", não tem relação direta com a estrutura do financiamento da educação, mas sim com o controle social. Os documentos que regem a organização da escola, de fato, são deixados de lado no cotidiano, mas a ciência dos mesmos, por parte dos profissionais e da comunidade é fundamental para o acompanhamento, fiscalização e intervenção quando necessário. A escola gere recursos que são destinados diretamente a ela, como, por exemplo, o dinheiro do Programa Dinheiro Direto na Escola (PDDE), do Mais-Educação, além de recursos próprios das Associações de Pais e Mestres (APM), sendo que a gestão desses recursos é com certeza mais efetiva na medida em que forem mais conhecidos os documentos norteadores do trabalho no ambiente escolar.

A última emenda que gostaríamos de comentar trata dos "Recursos para o desenvolvimento de políticas para ingresso de afrodescendentes e indígenas no magistério superior da rede pública de ensino", o ponto interessante desta proposição é prever a garantia de recursos e não somente implementação de políticas, demonstrando que o movimento social parece estar ampliando a sua ação, de maneira mais organizada, pois para além da defesa do princípio, está avaliando (e propondo) a materialização do princípio em políticas efetivas. 


\section{Quadro 2: Emendas CONAE Curitiba}

\begin{tabular}{|c|c|c|c|}
\hline Emenda & Quantidade & Conteúdo & Referência \\
\hline Supressiva parcial ou total & 1 & Fundo Social do pré sal & 478 \\
\hline \multirow{4}{*}{ Substitutiva } & \multirow{4}{*}{4} & Fundo Social do pré sal & 478 \\
\hline & & CAQ & 479 \\
\hline & & $\begin{array}{l}\text { LRF - desvincular as despesas com folha de pagamento dos trabalhadores } \\
\text { da educação aos limites de gastos }\end{array}$ & 483 \\
\hline & & Estimulo e consulta aos PPPs, currículos, regimentos, planos de gestão. & 511.5 .4 \\
\hline \multirow{5}{*}{ Nova emenda } & \multirow{5}{*}{5} & Garantia do transporte escolar com recursos além dos destinados a MDE & 2.13 .1 \\
\hline & & $\begin{array}{l}\text { Recursos para o desenvolvimento de politicas para ingresso de } \\
\text { afrodescendentes e indígenas no magistério superior da rede pública de } \\
\text { ensino }\end{array}$ & 3.14 .1 \\
\hline & & $\begin{array}{l}\text { Ampliar a oferta de educação pública superior, pois os programas federais } \\
\text { de subsidio não tem caráter permanente }\end{array}$ & 3.15 \\
\hline & & Cessamento dos benefícios para iniciativa privada até 2018 & 4.1.1 \\
\hline & & $\begin{array}{c}\text { Ampliação da contribuição do salário educação para } 3,5 \text { da folha de } \\
\text { pagamento }\end{array}$ & 520 \\
\hline
\end{tabular}

Fonte: Arquivos Conae Curitiba - Informações organizadas pelos autores, 2013.

\section{Conclusões}

Considerando o material disponibilizado, fruto da etapa municipal da Conae em Curitiba, obtivemos 33 emendas aditivas, 1 supressiva parcial ou total, 4 substitutivas e 5 novas emendas, no eixo VII- Financiamento da Educação.

Não foram aprovadas emendas com relação específica à educação infantil, mas também não temos a informação se emendas foram apresentadas e reprovadas pela assembleia. Considerando que em 2016 a obrigatoriedade do ensino passa a abranger todas as crianças e adolescentes dos 4 aos 17 anos, é estranho não ter havido emendas aprovadas sobre este tema, em particular considerando que a educação infantil não tem oferta universalizada no município de Curitiba.

Conferências se constituem em espaços democráticos, onde participam o poder público, a sociedade civil, os movimentos sociais, os representantes do setor privado, os trabalhadores da educação, dentre outros. Para cada emenda aprovada, podemos considerar a existência de grupos com ideias articuladas, que com maior ou menor grau de organização, conseguiram garantir na etapa municipal que o que consideram melhor para educação fosse debatido.

O momento agora, para o poder público e para a sociedade de Curitiba, com a aprovação do PNE 201420124, é da construção no novo Plano Municipal de Educação:

a grande questão para a sociedade e para os políticos é a seguinte: queremos ou não ter um PNE viável e coerente - com os sucedâneos Planos estaduais, Municipais e do Distrito Federal - para ser efetivamente cumprido? A experiência da lei $n^{0} 10.172$, de 2001, foi desastrosa. Simplesmente seus dispositivos foram ignorados nas leis orçamentárias da União e dos entes federados (MONLEVADE, 2011, p. 19)

Sem a articulação e consonância do PNE com os planos estaduais e municipais, é possível que boa parte do esforço realizado no plano nacional não se efetive. 
Mas, de outro lado, também é necessária muita vigilância e controle social. O município de Curitiba, como todo o Brasil, fez um esforço muito grande, necessário e construtivo, no processo da Conae 2014, buscando discutir ideias e apresentar propostas para o enfrentamento dos problemas históricos da educação em nosso país. A partir de agora, além do necessário debruçar-se sobre o plano municipal, é preciso que todos estejamos atentos às ações do Estado no cumprimento das metas do PNE, em particular as metas que dão materialidade mais concreta às ideias, que são as metas do financiamento da educação.

\section{Referências}

BRASIL. Constituição Federal de 1988. Disponível em http://www.planalto.gov.br/ccivil 03/constituicao/ constituicaocompilado.htm. Acesso em 01/dez/2014.

Lei de Diretrizes e Bases da Educação, Lei Federal 9.394/96. Disponível em http://www.planalto.gov. br/ccivil 03/leis/19394.htm. Acesso em 01/dez/2014.

Plano Nacional de Educação, Lei Federal 13.005/14. Disponível em http://www.planalto.gov.br/ ccivil_03/_Ato2011-2014/2014/Lei/L13005.htm. Acesso em 01/dez/2014.

Conae 2014: Documento Referência. Brasília, 2013. Disponível em http://conae2014.mec.gov.br/ images/pdf/doc referencia.pdf. Acesso em 01/dez/2014.

FERRAZ, J. P. V. Panorama do gasto-aluno nas redes estaduais e municipais brasileiras. Dissertação de mestrado (Mestrado em Educação). Curitiba: UFPR, 2013.

MONLEVADE, J. A. C. Percentual de recursos públicos para a educação: compromisso irrevogável do PIB. Jornal de Políticas Educacionais. v. 5, n. 9, jan-jun 2011, p. 11-19.

TRIBUNAL DE CONTAS DO PARANÁ. Provimento $\mathbf{n}^{\circ}$ 1, 1999. Disponível em http://www.tce.pr.gov.br/ acervo/1999/12/1000088.pdf. Acesso em 01/dez/2014.

Recebido em dezembro de 2014 - Aprovado em dezembro de 2014 


\section{PINTO, J. M.; SOUZA, S. A. de. (Org). Para onde vai o dinheiro? Caminhos de descaminhos do financiamento da educação. São Paulo: Xãma, 2014, 208 p.}

\section{Por Bruna Caroline Camargo}

O financiamento destinado a educação é um tema que tem despertado inúmeros debates no ambiente acadêmico.

A obra "Para onde vai o dinheiro? Caminhos de descaminhos do financiamento da educação" busca discutir, em dez artigos, diversos temas relacionados ao financiamento da educação, os quais possuem ligações entre si, ou seja, todos os temas abordados estão interligados.

O primeiro artigo intitulado "Construção da complexidade do financiamento da educação pública no Brasil", autoria de João Antonio Monlevade traz um retrospecto histórico da construção do financiamento da educação no Brasil. Monlevade salienta que antes dos jesuítas, os indígenas já traziam aspectos relacionados ao processo educativo, objetivando reproduzir sua cultura, porém, não possuíam estrutura física.

O autor afirma que no período dos jesuítas, as arrecadações para suprir os gastos dos colégios e dos religiosos não eram suficientes. Dessa maneira, criou-se um sistema de autofinanciamento por meio de trabalhos escravos e posse de terras e rebanhos. Após a expulsão dos jesuítas criou-se o "subsídio-literário", um tributo destinado ao financiamento da educação. Todavia, Monlevade relata que esse tributo não permitia pagar adequadamente os mestres da escola.

A Constituição de 1934 trouxe avanços para a educação, pois foram vinculados percentuais a serem investidos pelos entes federados. Entretanto, como salienta Monlevade, após esse período tiveram-se momentos em que a obrigatoriedade dessas vinculações foram retiradas.

O autor aponta que por volta de 1960, a industrialização impulsionou a procura por escolas de ensino fundamental e médio público. Entretanto, os estados e municípios, responsáveis pela oferta dessas etapas do ensino não tiveram o crescimento na arrecadação de impostos proporcionais a demanda por matrícula. Monlevade chama esse período de "crise aguda do financiamento da educação pública".

Dentre outros elementos, o autor faz uma avaliação sobre o FUNDEF (Fundo de Manutenção e Desenvolvimento do Ensino Fundamental e de Valorização do Magistério) e FUNDEB (Fundo de Manutenção e Desenvolvimento da Educação Básica e de Valorização dos Profissionais da Educação). Monlevade afirma que o FUNDEF teve efeito nos municípios que pagavam salários muito baixos. Os estados que remuneravam melhor os professores perdiam recursos, ocasionado arrocho salarial e greves estaduais.

Quanto ao FUNDEB, o autor afirma que houve melhorias no custo-aluno anual e nos salários dos profissionais da educação.

O segundo artigo, intitulado "Desafios atuais referentes ao financiamento de uma educação de qualidade", autoria de Andréa Barbosa Gouveia e Angelo Ricardo e Souza, traz dados relativos à qualidade da educação. Os autores trazem dados do FUNDEB, mostrando que apenas dois estados - Roraima e Mato Grosso - ganham efetivamente com o fundo.

Os autores apresentam um índice, construído pelo Núcleo de Políticas Educacionais da Universidade Federal do Paraná, chamado de "Índice de Condições de Qualidade (ICQ)". Esse índice é composto por outros 
elementos, a saber: Índice de Condições Materiais e Estruturais (ICME); Índice de Condições do Professor (ICP); e Índice de Condições a Gestão Escolar (ICG).

Dessa maneira, Gouveia e Souza apresentam dados obtidos pelo uso do ICQ, nos anos de 2007 e 2009, em todos os estados e capitais brasileiras.

De maneira geral, os estados tiveram mais investimentos em educação em 2009 comparados a 2007. Nos dados apresentados pelos autores tiveram estados que obtiveram mais investimentos, porém o ICQ diminuiu; estados que tiveram queda no gasto-aluno mais aumento do ICQ; estados com queda no gasto-aluno e queda no ICQ; estados com crescimento do gasto-aluno e queda no ICQ; e estados com crescimento no gasto-aluno e aumento do ICQ.

Em relação ao ICME, todos os estados tiveram quedas significados de 2007 para 2009. O ICG apresentou melhor desempenho, de um modo geral, pois teve decréscimo em dois estados. Os autores mostram que ICME também teve queda nos municípios.

Na rede municipal, os autores afirmam que as condições do ICG são piores comparadas a rede estadual. Em contrapartida, o ICP possui um desempenho melhor nas redes municipais comparados as redes estaduais.

Por fim, Gouveia e Souza apontam que a qualidade da educação envolve um conjunto de elementos e mostram a importância do PNE frente a isso.

O artigo "Panorama do gasto público em educação na esfera estadual", autoria de Nalú Farenzena, traz a oferta e gasto na educação pública em redes estaduais de ensino, a partir de 1990, por regiões brasileiras e por estado.

A autora mostra por meios dos dados analisados a desigualdade em geração de riqueza entre as regiões brasileiras. O menor PIB fica na região norte e nordeste, além de que as diferenças permanecem entre os estados dessas mesmas regiões. Farenzena afirma que as diferenças do PIB influenciam na capacidade de financiamento da educação básica, pois são as receitas resultantes de impostos dos governos que são mais significativas.

O processo de municipalização também é discutido pela autora, o qual foi induzido pelo FUNDEF. Todavia, existem estados que já haviam iniciado o processo de municipalização por outros fatores, dentre eles crise fiscal do estado e ideia de descentralização.

A autora selecionou os anos de 2004, 2006 e 2010 para a análise. De 2004 para 2006, o gasto anual por aluno aumentou nos estados, exceto nos estados de Rio Grande do Sul e Alagoas. Comparando 2004 a 2010, todos os estados obtiveram aumento no gasto aluno/ano.

A autora Rosana Evangelista da Cruz traz uma análise da gestão dos recursos federais na política da educação básica, enfocando programa Fundo Nacional de Desenvolvimento da Educação (FNDE), no artigo "Os recursos federais para o financiamento da educação básica".

A autora expõe que o MEC (Ministério da Educação e Cultura) é responsável pelo curso das políticas educacionais do governo federal, pois essa é uma atribuição da União. Todavia, a União direciona a maior parte dos recursos federais para o ensino superior.

Dessa maneira, objetivando a universalização do ensino obrigatório e a função supletiva e redistributiva, a União necessita do FNDE, o qual auxilia no financiamento da educação pública obrigatória nos estados e municípios.

Os dados apresentados pela autora mostram que em $2011,78,8 \%$ dos recursos do FNDE foram geridos pelo MEC, em que três programas possuem quase a totalidade dos recursos financeiros executados pelo FNDE, a saber: Projovem (100\%), Brasil Alfabetizado e EJA (99\%) e Brasil Escolarizado (96\%).

Por fim, a autora conclui que a União desenvolve estratégias para cumprir o exposto no artigo 211 da Constituição Federal, ou seja, exercer sua função supletiva e redistributiva.

O quinto artigo, intitulado "Constrangimentos socioeconômicos no acesso à educação superior no Brasil", autoria de Nelson Cardoso Amaral discutir o acesso ao ensino superior, trazendo dados que buscam analisar 
as informações financeiras dos censos financeiros da educação superior e dados de execução orçamentária do governo federal.

Por meio dos dados, o autor mostra que as Instituições de Educação Superior (IES) municipais e privadas tem a maior parte do financiamento com receitas próprias. As IES estaduais e municipais obtém a maior parte de seu financiamento com receitas de transferência.

O autor analisa a meta 12 do Plano Nacional de Educação (2014-2024), a qual discorre acerca da universalização do ensino superior, propondo-se em elevar a taxa de matrícula líquida no ensino superior em 33\% até o último ano de vigência do PNE. Em 2009, esse percentual correspondia a 15 \%.

Amaral destaca que em 2009, 74,4\% das matrículas no ensino superior no Brasil eram em IES privadas. Comparando com alguns países, o Brasil possui percentual menor apenas que o Chile (76,65\%), a Coreia do Sul $(80,2 \%)$ e o Japão $(79,2 \%)$. Além disso, a análise do autor mostra que em 2023 , as matrículas no ensino superior no Brasil continuariam no setor privado.

O autor afirma que para universalizar o ensino superior é necessário também atuar massivamente no ensino médio, pois o número de concluintes é baixo. Assim, é importante elevar o percentual de concluintes o ensino médio para que sejam habilitados a cursar o ensino superior.

O artigo "As relações entre o público e o privado na oferta educacional no Brasil", de autoria de Theresa Adrião busca discutir, de um modo geral, a influência do setor privado na educação. A autora relata que, muitas vezes, tem-se a falsa ideia de que a qualidade está no setor privado.

Essa ideia concretiza-se nas parcerias entre os estados e municípios com o setor privado, como por exemplo, na assessoria a gestão de educação, compra de materiais didáticos do setor privado para ser utilizado em escolas públicas, dentre outros.

Além disso, como afirma a autora, a Lei de Diretrizes e Bases da Educação Brasileira (LDB) permite que os recursos públicos sejam destinados a instituições privadas na educação, respeitando algumas observações.

Em defesa da esfera pública, a autora conclui que é necessário fortalecer e qualificar a gestão pública, almejando-se a articulação entre união, estados, distrito federal e municípios, além do apoio financeiro da união.

O autor Paulo Sena analisa o financiamento da educação no Legislativo no artigo intitulado "O financiamento da educação no Legislativo". O autor relata que após 1988 o financiamento da educação teve importantes dispositivos.

Segundo Sena, o Legislativo tem desempenhado um importante papel frente ao financiamento da educação, contrariando a ideia de que atuava como coadjuvante do Poder Executivo. Assim, o autor elabora um quadro, com leis relacionadas ao financiamento da educação, mostrando que o Legislativo tem atuado nessa área.

Além disso, salienta a importância do Legislativo, pois os movimentos sociais podem fortalecer suas propostas por meio das audiências públicas.

O artigo "Controle estatal ou social das verbas de educação?", de autoria de Nicholas Davies busca discutir o controle da aplicação de verbas da educação a partir dos relatórios dos tribunais de contas de estados e municípios e do controle social dos conselhos do FUNDEB.

O autor afirma que alguns tribunais de contas (TCs) possuem muitas informações, enquanto outros não seguem as normas estabelecidas pela LDB e nem as normas da Secretaria do Tesouro Nacional para elaboração dos relatórios. Além disso, afirma que, às vezes, os gastos são contabilizados em diferentes órgãos, dificultando a análise de todos os gastos.

$\mathrm{Na}$ análise dos relatórios, o autor encontrou diversos equívocos, como, por exemplo: pagamento do pessoal inativo da educação como remuneração e não proventos.

Em relação aos conselhos do FUNDEB, o autor salienta que esses podem funcionar mais na teoria, pois o potencial democrático desses é limitado, visto que são mais estatais que sociais, pois possuem mais representantes do Estado de que da sociedade. 
O autor José Marcelino Pinto, no artigo "Dinheiro traz felicidade? A relação entre insumos e qualidade na educação" discute a complexidade entre insumos e qualidade na educação, dialogando com outros autores.

O autor afirma que o nível socioeconômico da família está relacionado com o desempenho do estudante, sendo essa uma crítica do autor aos testes padronizados, os quais não consideram esse elemento.

Segundo Pinto, os testes são importantes, porém, devem considerar outros fatores. O "ranking" de escolas na percepção do autor é negativo, pois ocasiona fuga de professores e diretores.

O autor salienta que falta um sistema nacional de educação, pois o que existem são amontoados de testes, os quais não expressam totalmente a realidade brasileira. Além disso, afirma que o dinheiro faz diferença na qualidade do ensino, tendo-se as escolas técnicas federais, em relação ao gasto-aluno, como exemplo a ser seguido.

Por fim, o artigo "Financiamento e remuneração docente na educação básica", de autoria de Márcia Aparecida Jacomini, Maria Angélica P. Minhoto e Rubens Barbosa de Camargo busca analisar aspectos quanto ao vencimento, carreira e remuneração docente em doze estado brasileiros e suas capitais, no ano de 2010, sendo fruto de uma pesquisa nacional financiada pela CAPES.

Os autores salientam que a remuneração docente integra os insumos necessários para a qualidade da educação, a qual é composta pelo vencimento e vantagens pecuniárias. Além disso, a remuneração docente é definida a partir de cada esfera administrativa.

A análise dos planos de carreira realizada pelos autores mostra que em todos os estados da pesquisa, temse diferença no vencimento de acordo com o nível de formação.

Os autores afirmam, por meio de dados analisados, que em 2010 cinco estados e dois municípios tiveram o valor hora-aula abaixo do estabelecido pelo Piso Salarial Profissional Nacional, sendo eles: Minas Gerais, Santa Catarina, Rio Grande do Norte, Rio Grande do Sul, Pará, João Pessoa e Florianópolis.

Segundo os autores, a dispersão salarial, o que corresponde a distância entre menor e maior remuneração, do início ao fim da carreira (DUTRA JUNIOR apud JACOMINI et al, 2014, p. 180) é maior nas redes municipais comparadas as redes estaduais, o que pode demonstrar maior atratividade da carreira no âmbito estadual do que municipal.

A obra "Para onde vai o dinheiro? Caminhos de descaminhos do financiamento da educação" traz inúmeras contribuições para a educação. Os artigos abordam questões importantes, em que um complementa o outro.

A leitura do livro permite concluir que o financiamento é um dos elementos que pode proporcionar a melhoria educacional, a qual está relacionada com a qualidade da educação, universalização da educação, acesso, permanência, dentre outros. 


\title{
RESUMOS DE TESES E DISSERTAÇÕES
}

\section{A disformidade no desenho da oferta educacional e a fragilização do direito à educação: um panorama da oferta de matrículas do ensino fundamental no Brasil}

\author{
Autora: Marilene Zampiri \\ Nível: Doutorado (PPGE/UFPR) \\ Orientador: Prof. Dr. Ângelo Ricardo de Souza
}

Esta pesquisa examina as formas de entrada nos processos de escolarização pública como condição primordial ao acesso e fruição ao direito à educação, tendo por base o pacto federativo reorganizado na Constituição Federal de 1988 e a assimetria socioeconômica que marca os entes federados. O objetivo dessa análise foi compor um panorama das formas acordadas entre os entes federados, estado e municípios, para a oferta de matrículas públicas. O estudo está circunscrito ao ensino fundamental, o qual, instituído como direito público subjetivo, impõe ao Estado o dever na sua disponibilização material e, ao mesmo tempo, impede o sujeito deste direito a sua alienação ou recusa. A investigação mostrou que, apesar da Constituição Federal de 1988 indicar o regime de colaboração como instrumento para modelar os acordos na responsabilização com os encargos educacionais, ao não regulamentá-lo, abriu possibilidade para elaboração de variadas formas nos acordos, mais precisamente, tantos quantos são os entes federados, já que todos são autônomos e legalmente estão aptos a formular suas próprias políticas educacionais. Concomitantemente, foram consideradas as políticas de fundos (FUNDEF e FUNDEB) como delimitadoras do período analisado, tendo em vista que tais políticas, especialmente o FUNDEF, porque focado no ensino fundamental, influenciou fortemente a transferência e assunção dos encargos educacionais entre os entes federados, consequentemente, influenciando o desenho da oferta no Brasil. Portanto, o estudo restringiu-se à análise das matrículas em três ocasiões: 1996 (antes da vigência do FUNDEF), 2006 (fim da vigência do FUNDEF e ano anterior ao funcionamento do FUNDEB) e 2012 (situação mais recente de informações de matrículas). As informações das matrículas, organizadas a partir de dois critérios, a oferta partilhada entre os dois níveis administrativos (municipal e estadual) e a oferta exclusiva de um ou outro, revelaram um quadro disforme na modelagem dos acordos para a oferta educacional, tanto entre as unidades federativas como entre as fases desta etapa da educação básica, anos iniciais e finais. A ausência de uma articulação entre os entes federados produziu um panorama marcado por modelos disformes e não vinculados à equalização das trajetórias educacionais e, desta maneira, com boa probabilidade de fragilizar o direito à educação. Assim, o Estado deixa de cumprir o dever constitucional da distribuição material do direito reconhecido socialmente e protegido juridicamente. O estudo mostra que superar a desigualdade no acesso e fruição do direito requer, antes de tudo, enfrentar a disformidade no quadro de oferta dos encargos educacionais.

Palavras-chave: Direito à educação. Políticas Educacionais. Ensino fundamental. Federalismo. Regime de colaboração. 


\title{
RESUMOS DE TESES E DISSERTAÇÕES
}

\section{Concepção, regulação e gestão da carreira docente no Brasil e no Chile no contexto das reformas educacionais}

\author{
Autora: Diana Cristina de Abreu \\ Nível: Doutorado (PPGE/UFPR) \\ Orientador: Prof. Dr. Ângelo Ricardo de Souza
}

A pesquisa, Concepção, regulação e gestão da carreira docente no Brasil e no Chile no contexto das reformas educacionais, busca compreender, fazendo uso de uma metodologia de estudo comparado, como as reformas educacionais ocorridas na América Latina, interferem nas políticas adotadas pelos estados nacionais do Brasil e do Chile no que diz respeito à carreira docente. A análise sobre Carreira Docente tem seu enfoque no campo da política educacional, inicialmente consideramos sua dimensão jurídica, ou seja, o conjunto de regras reguladoras da profissão que, geralmente vem definida nos estatutos ou planos de carreiras e como essa regulação constrói paulatinamente a profissão docente. Realizou-se uma análise nos documentos produzidos pelo PREAL - Programa de Promoción de la Reforma Educativa en América Latina y el Caribe entre os anos de 2002 a 2012, identificando as principais recomendações do Preal para a Carreira Docente na América Latina. A pesquisa apresenta seguinte estrutura: No capítulo I, considerando aporte teórico de (KRAWCZYK, 2000a; AFONSO, 2003; DALE, 2004; CASASSUS, 2004), percebe-se que em meio à discursiva de homogeneização das reformas educacionais das últimas décadas, emerge outras possibilidades analíticas quanto às especificidades regionais e locais na definição das políticas para a educação no âmbito dos estados nacionais. Nos capítulos II e III, buscou-se a construção de um panorama para a carreira docente, a partir do estudo de planos de carreira de doze estados e doze capitais brasileiras, cotejadas ao movimento da política e da legislação educacional. Nos capítulos IV e V, utilizando-se da análise de legislações e literaturas sobre carreira docente, buscou-se estabelecer um panorama, sobre a temática no Chile. E por fim apresentados os dados empíricos de Brasil e Chile para regramento e definições para carreira docente, estabeleceu-se algumas regularidades e discrepâncias nas políticas adotadas em ambos contextos e como estas se articulam às discursivas apregoadas nas reformas educacionais direcionadas pelo PREAL. Entre as recomendações, estão a superação de estruturas de carreira docente baseadas na antiguidade e na titulação acadêmica. Os dados empíricos revelam que mesmo no Chile onde vários modelos de avaliação de desempenho docente são empregados, há prevalência de mecanismos tradicionais nas estruturas de carreira. Entretanto, as últimas inciativas governamentais no campo das políticas educacionais, em mostrado a preocupação com a instituição de novos critérios de recrutamento, aumento da atratividade, e incentivos para a permanência na carreira docente.

Palavras Chaves: Carreira Docente; Valorização do Magistério; PREAL; Reformas Educacionais; Planos de carreira; Estatuto Docente. 


\title{
RESUMOS DE TESES E DISSERTAÇÕES
}

\section{O provimento do diretor nas escolas públicas brasileiras e suas implicações na gestão escolar}

\author{
Autora: Julianna Laudicelli de Oliveira Cruz \\ Nível: Mestrado (PPGE/UFPR) \\ Orientador: Prof. Dr. Ângelo Ricardo de Souza
}

Frente às discussões sobre a autonomia da escola pública brasileira, que teve seu ápice na década de 1980 em decorrência do processo de redemocratização do país, faz-se necessário refletir a gestão escolar na perspectiva de sua democratização. Neste sentido, esta pesquisa problematiza as formas de provimento do diretor escolar nas escolas públicas brasileiras de Ensino Fundamental. A Constituição Federal de 1988 e a Lei de Diretrizes e Bases da Educação Nacional n9394/96 indicam a gestão democrática no ensino público, porém cada sistema de ensino adota diferentes meios para sua efetivação, dentre eles, a forma como é escolhido o diretor escolar. Diante disso, apresenta-se a proposição de retomar a constituição teórica da gestão escolar no Brasil, a fim de identificar os modelos de provimento adotados nos diferentes sistemas de ensino e as possíveis implicações de cada modelo para a gestão escolar. Para tanto, a pesquisa realizou um levantamento bibliográfico, e também um levantamento de caráter empírico que teve como fonte de análise os dados da Prova Brasil 2011, aplicado bienalmente pelo INEP - Instituto Nacional de Estudos e Pesquisas Educacionais. Utilizando os dados referentes aos diretores de escola, bem como dos professores, foram realizadas também entrevistas com os responsáveis pelos sistemas de ensino e os diretores de escola nas diferentes regiões do Brasil, em cinco capitais pré-selecionadas conforme modalidade de provimento, a fim de identificar as potencialidades e fragilidades presentes em cada modelo distinto. Os dados apontam para um aumento significativo nos últimos anos de formas mais democráticas para a escolha do diretor escolar, e uma forte presença de avaliação prévia de competências técnicas que antecedem o momento de escolha pela competência política.

Palavras-chave: Gestão escolar; Políticas Educacionais; Diretor Escolar. 


\title{
RESUMOS DE TESES E DISSERTAÇÕES
}

\section{A carreira das educadoras da educação infantil no município de Curitiba: integração com a educação ou consolidação da marginalização?}

\author{
Autora: Beatriz T. Muraski Heck \\ Nível: Mestrado (PPGE/UFPR) \\ Orientador: Prof. Dr. Marcos Edgar Bassi
}

No Município de Curitiba, a educação das crianças de 0 a 5 anos é realizada pelas educadoras e professoras nos Centros Municipais de educação Infantil (CMEI) e nas escolas, nas turmas de pré-escola, somente pelas professoras. Diante da determinação de integração das instituições de creches e pré-escolas aos sistemas de ensino pela LDB/96, uma questão se impõe: a carreira das educadoras da educação infantil no Município de Curitiba foi integrada à educação ou faz parte de um processo que consolida a marginalização? A presente pesquisa pretende examinar a conformação e o funcionamento da carreira das educadoras da Educação Infantil do Município de Curitiba, que não têm sua atuação regulamentada pelo Estatuto do Magistério, mas pelo Estatuto dos Servidores Municipais, analisando porque há duas carreiras para a atuação na educação das crianças de 0 a 5 anos, considerando a legislação vigente. Ambas as profissionais docentes pertencem à carreiras distintas: as primeiras pertencem à carreira de Educadoras e as segundas à carreira dos Profissionais do Magistério. A compreensão do objeto de estudo requereu um breve resgate histórico da consolidação das políticas para a Educação Infantil, da qual decorrem os dilemas e ambiguidades vivenciados por suas profissionais. A análise documental pautou-se em alguns dos principais documentos nacionais e do Município de Curitiba que regulamentam à condição docente na El: Leis, Pareceres, Resoluções, Decretos, Portarias. A análise dos dados possibilitou a visualização de que a carreira de educadora é resultado da hierarquização das funções do cuidar e educar, uma construção advinda do delineamento de projetos educacionais historicamente distintos quanto aos seus objetivos para as creches e pré-escolas. Deste modo, as educadoras seguem com uma carreira que carrega os estigmas da segregação de um modelo de atendimento anterior a Constituição Federa de 1988 e a LDB/96, voltado às crianças pobres de 0 a 3 anos. A análise aponta para a necessidade de superar desigualdades quanto à jornada, remuneração, formação, restrições aos locais de atuação, aposentadoria especial, entre outros aspectos. 


\title{
RESUMOS DE TESES E DISSERTAÇÕES
}

\section{A política pública do transporte escolar e a garantia do direito à educação à luz do regime de colaboração: o exemplo do Paraná}

\author{
Autora: Elisângela Belniaki Hochuli \\ Nível: Mestrado (PPGE/UFPR) \\ Orientador: Prof. Dr. Marcos Edgar Bassi
}

O presente trabalho refere-se ao estudo da política pública do transporte escolar no Brasil, no período de 2004 a 2012. De caráter qualitativo e quantitativo, desenvolvido mediante análise documental e a partir de dados obtidos em sistemas de informação, utilizou como categorias de análise o regime de colaboração e o direito à educação. Como a gestão, normatização e o financiamento desta política são executados pelos três entes federados, utilizou-se os dados do estado do Paraná para exemplificar e analisar se o regime de colaboração tem se efetivado na política do TE, assim como se a relação entre os três níveis de governo, respeitado o princípio da autonomia, tem sido de efetivo diálogo, articulação e cooperação. Constatou-se que, apesar dos inúmeros avanços, muitos desafios continuam presentes na política, na atualidade, como a necessidade de definição dos papéis de cada ente federado no regime de colaboração, tanto no financiamento, por meio da busca do equilíbrio entre a capacidade tributária e a sua participação na política do transporte escolar, como na definição de critérios, na normatização e no seu acompanhamento. Evidenciou-se, também, a importância da articulação e cooperação entre os entes para garantia do direito à educação, mediante a oferta do transporte escolar de qualidade à todos os estudantes que dele dependem para poder acessar e permanecer na escola. 


\title{
RESUMOS DE TESES E DISSERTAÇÕES
}

\section{Políticas de Reestruturação Curricular no Ensino Médio: uma análise do Programa Ensino Médio Inovador}

\author{
Autora: Vanessa Campos de Lara Jakimiu \\ Nível: Mestrado (PPGE/UFPR) \\ Orientadora: Profa. Dra. Monica Ribeiro da Silva
}

O estudo em questão traz em seu conteúdo uma análise do Programa Ensino Médio Inovador (ProEMI), sendo que a ênfase recai sobre as questões curriculares. Tendo em vista que o ProEMI busca induzir o delineamento de uma nova organização curricular para o Ensino Médio, propõe-se responder ao seguinte problema de pesquisa: Que aspectos são instituídos no âmbito das proposições do ProEMl que caracterizam indução ao redesenho curricular na última etapa da Educação Básica? Para responder a este problema de pesquisa, inicialmente, este estudo investiga os antecedentes que deram origem ao Programa. Assim, faz-se uma retomada da trajetória das políticas e dos preceitos voltados para o Ensino Médio no período de 1996 a 2014 com especial destaque para as ações e programas que focalizaram alterações no currículo escolar. A partir da necessidade de investigar as mudanças curriculares propostas e considerando que o ProEMI é uma política em andamento, faz-se uma análise dos documentos orientadores do Programa em suas diferentes versões (2009, 2011 e 2013), buscando clarificar quais foram as principais alterações que ocorreram nas proposições trazidas nesses documentos, tanto com relação ao fundamentos teóricos, quanto com relação aos aspectos didático-metodológicos. Esta pesquisa também apresenta uma discussão conceitual acerca da perspectiva curricular posta pelo ProEMI, buscando evidenciar a partir de quais elementos se consolidaria um currículo inovador no Ensino Médio. Assim, sujeitos, conhecimentos, tempos e espaços são apontados como elementos que subsidiam o conceito de inovação tendo como eixo central a perspectiva da integração curricular. Por fim, a investigação, a partir do corpus teórico definido na pesquisa, busca ilustrar as proposições do ProEMI ganhando materialidade no currículo do Ensino Médio. Para tal, realiza-se uma análise do Projeto de Redesenho Curricular (PRC) do Colégio Estadual Nirlei Medeiros localizado em Curitiba-PR, apontando em que medida as propostas contidas no PRC dessa escola se aproximam ou se distanciam dos pressupostos do Programa. Desta ação foi possível observar elementos que denotam que, assim como o próprio Programa encontra-se em implementação, o currículo escolar do Ensino Médio também se situa em movimento, ganhando novos contornos a partir das inovações curriculares suscitadas pelo ProEMI. Enquanto delineamento metodológico o presente estudo adota os moldes da pesquisa bibliográfica documental, sendo que a base empírica está demarcada pelos documentos orientadores do Programa Ensino Médio Inovador (2009, 2011 e 2013), pelo PRC do Colégio Estadual Nirlei Medeiros, e as bases teóricas são concernentes às políticas curriculares para o Ensino Médio. Do estudo empreendido, foi possível constatar que o ProEMI, considerando suas fragilidades e suas potencialidades, sinaliza para potenciais mudanças no currículo do Ensino Médio em direção a formas menos fragmentadas de organização do conhecimento escolar.

Palavras-chave: Ensino Médio. Políticas de Currículo. Programa Ensino Médio Inovador. ProEMI. Redesenho Curricular. 


\title{
RESUMOS DE TESES E DISSERTAÇÕES
}

\section{O Programa Ensino Médio Inovador e suar com os dados de fluxo escolar}

\author{
Autora: Vanessa Campos de Lara Jakimiu \\ Nível: Mestrado (PPGE/UFPR) \\ Orientadora: Profa. Dra. Monica Ribeiro da Silva
}

O presente trabalho tem como objeto de pesquisa o Programa Ensino Médio Inovador-ProEMI e sua relação com o fluxo escolar. O ProEMI foi criado em 2009, pela Secretaria da Educação Básica do Ministério da Educação, instituído pela Portaria n 971, de 09/10/2009 e tem como público alvo as escolas públicas de Ensino Médio, não profissionalizantes. Desde a sua criação, foram publicadas três versões do Documento Orientador do ProEMI, que oferecem orientações voltadas à implantação, implementação, acompanhamento e avaliação do Programa. Como parte de seus objetivos o ProEMI busca induzir mudanças curriculares, ampliar a carga horária, incentivar práticas pedagógicas diferenciadas e contribuir para o enfrentamento da reprovação e do abandono escolar. Com base nas finalidades e nas orientações do Programa, o objetivo central desta pesquisa foi monitorar os resultados do abandono e da reprovação escolar e averiguar em que medida o ProEMI pode contribuir para o movimento destas taxas bem como se este movimento sinaliza alguma tendência para o cenário nacional. Para isso, investigaram-se os dados de fluxo escolar (reprovação e abandono) das escolas estaduais sem o Programa e do conjunto de escolas com o ProEMI (339), que fizeram adesão em 2009, distribuídas em 17 estados e no Distrito Federal. Como parte do procedimento de coleta de dados, utilizou-se como referência os dados disponibilizados pelo Instituto Nacional de Estudos e Pesquisas Educacionais, do período de 2007-2011. Por meio dos dados levantados, foram identificadas quatro tendências diferentes no movimento do fluxo escolar de cada estado participante e de seu conjunto de escolas com e sem o ProEMI.

Palavras chaves: Programa Ensino Médio Inovador. ProEMI. Abandono escolar. Reprovação escolar. Fluxo escolar. 


\section{Instruções para Submissão de Trabalhos}

Jornal de Políticas Educacionais aceita trabalhos que tratem de temas relacionados a: políticas educacionais, gestão educacional e escolar, financiamento da educação, financiamento escolar, avaliação educacional, políticas afirmativas e de inclusão, e que cumpram com as seguintes exigências:

1. Artigos inéditos, em português, inglês ou espanhol: A extensão de cada artigo deverá ser de, no máximo, 40.000 caracteres (com espaços), incluindo referências bibliográficas, ilustrações, gráficos, mapas e tabelas. Resumo, na língua do artigo e em inglês, de no máximo 230 (duzentas e trinta) palavras - incluído logo abaixo do(s) nome(s) do(s) autor(es). Até cinco palavras-chave na língua do artigo e em inglês. Texto em Word for Windows obedecendo às seguintes recomendações: letra Times New Roman, tamanho 12, espaço 1,5, papel A4, margens de $2,5 \mathrm{~cm}$, paginação no canto inferior direito.

2. Identificação no alto da página incluindo: Título do trabalho (na língua do artigo e em inglês) - em caso de financiamento da pesquisa, a instituição financiadora deverá ser mencionada em nota de rodapé. Nome(s) do(s) autor(es) - titulação máxima (instituição, opcional), instituição à qual se vincula, e.mail (opcional), em nota de rodapé.

3. As notas de rodapé deverão ser utilizadas para esclarecimentos absolutamente necessários. Os autores mencionados no artigo deverão ser citados entre parênteses no corpo do texto, com o ano da publicação da obra e, quando for o caso, com a(s) página(s) citada(s). Ex.: (CALKINS, 1950, p.161).

4. As referências bibliográficas deverão seguir as normas da ABNT.

5. As resenhas poderão ter, no máximo, 5 (cinco) páginas e o título será a referência bibliográfica completa da obra resenhada. Ex.: FARENZENA, N. A política de Financiamento da Educação Básica: rumos da legislação brasileira. Porto Alegre: Editora UFRGS, 2006. Palavras-chave e resumo não são necessários.

6. As traduções deverão vir acompanhadas de autorização do autor e do original do texto.

7. Os textos devem ser enviados por meio do portal SER/OJS (www.ser.ufpr.br/jpe). Deve acompanhar uma carta ou mensagem ao editor do Jornal de Políticas Educacionais autorizando sua publicação, com endereço completo do(s) autor(es) para correspondência.

8. Os textos recebidos serão encaminhados a 2 (dois) pareceristas ad hoc. Caso ocorram pareceres divergentes serão enviados para um terceiro consultor.

9. Somente serão apreciados os textos que obedecerem aos itens de 1 a 8 das normas estabelecidas para publicação.

10. Jornal de Políticas Educacionais reserva-se o direito, se achar conveniente, de não publicar trabalho(s) de mesmo(s) autor(es) em intervalos menores que 2 (duas) edições, salvo em números especiais.

11. A aceitação da matéria para a publicação implica a transferência de direitos autorais para o periódico. Assegura-se ao Jornal de Políticas Educacionais o direito à divulgação da informação e os direitos editoriais, na forma da Lei.

12. Endereço para correspondência: Jornal de Políticas Educacionais, Universidade Federal do Paraná Núcleo de Política, Gestão e Financiamento da Educação - NuPE/UFPR, Rua General Carneiro, 460, 4ªndar, sala 407-C, CEP 80.060-150 - Curitiba - PR - Brasil. E-mail: jpe@ufpr.br 